Grain Lester. Ford

rirficrtirn.

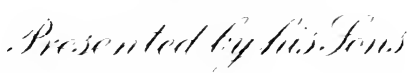

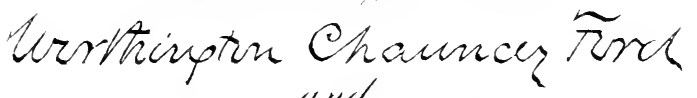

Paulbeicester ford ti. this

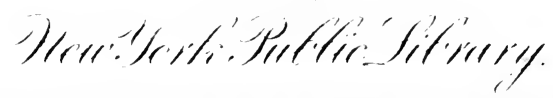


KI

Gares 



$(-s(a, \cdots)$ 



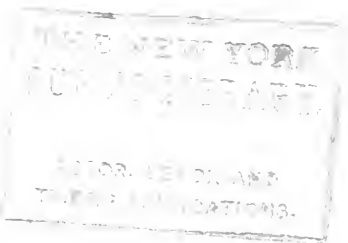



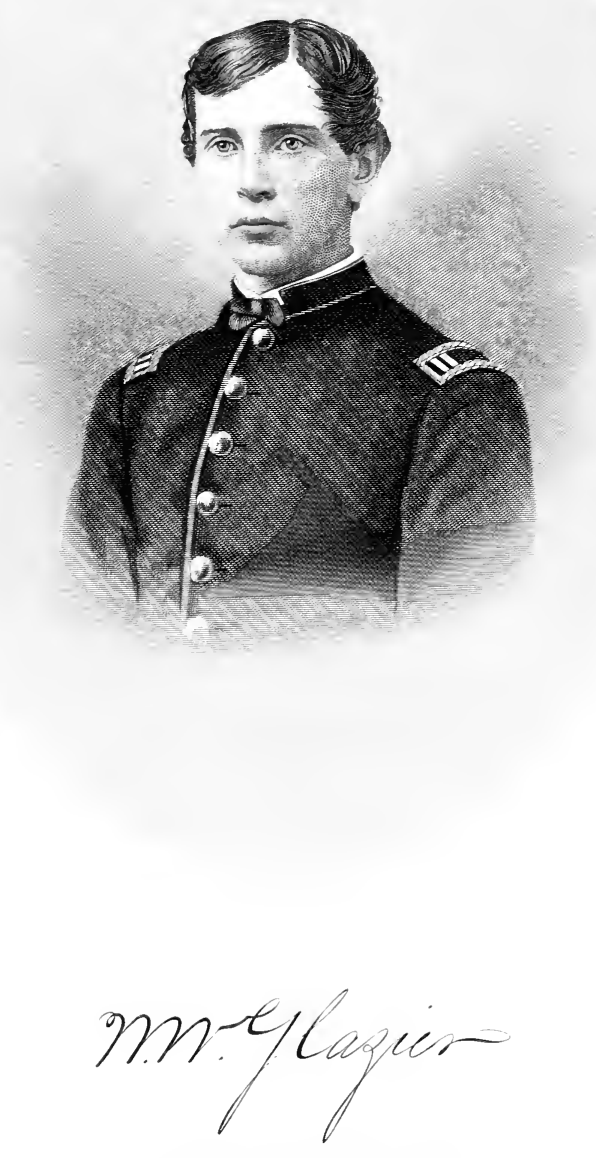


\section{CAPTURE,}

T:E

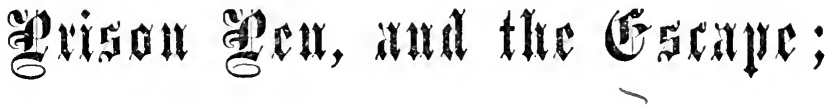

GIVING A COMPLETE

\section{IIISTORY OF PRISON LIFE IN TIIE SOUTII,}

PRINCIPALLY AT

BIOMOND, DANVILLE, MAOOY, SAVANNAE, OHARLESTON, COLUMBiA, BELLE ISLE, MIL. LIX, SALISBURY, AND AXDERSONVILLE: DESORIBNG THE ARRTVAL OF PRISONERS, AND PLANS OF ESOAPE, TOGETHER WITH NUMEROUS AND VARIED INCIDENTS AND ANEODOTES OF PRISON LIFE: EMBRAOLNG, ALSO, THE ADVENTURES OF THE AUTHOR'S EBOAPE FRIM OOLUMBLA, SOLTI OAROLNNA, HS FECAPTCRE, SCBSEQUENT FSOAPE, REOAPTCBE, TRIAL AS SPY, AND

IIIS FINAL AND SUOOESGFUL ESOAPE FROM SYLVAXIA, GEORGIA.

BY

CAPTAIN WILLARD WORCESTER GLAZIER, Author of "Three Fears in the Federal Cavalry," "Virginia's Battle-fields," ctc., etc., etc.

To whlch is added an Appendix, contalning the Name, Rank, Reglment, and Post-ogec address of Prisoners.

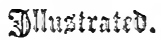

NEW YORK:

R. H. FERGUSON \& CO., PUBLISHERS. 1870 . 


\section{4}

Entered, according to Act of Congress, in the year 1865, by

WILLARD W. GLAZIER,

In the Clerk's Office of the District Court of the United States for the Forthern District of New York.

TRE. TROW \& SMITH BOOK YANTFACTERING COMPANY, 
THE WIDOWS, CHILDREN, FATHERS, MOTHERS, BROTHERS, SISTERS, FRIENDS, AND SURVIVING COMTADES

Of the Thollsands of Babe ifon

WHO LEFT THE PLEASCRES AND COMFORTS OF HOME, ABANDONED CHERISHED ENTERPRISES AND BUSINESS SCHEMES,

FOR THE PURPOSE OF SERVING THEIR COUNTRY,

AND WHO HAVE BEEN CAPTURED BY THE ENEMY WHILE

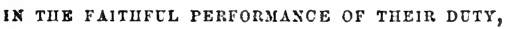

AND GONE DOWI

TO UNTIMLY GRATES THROUGH UNPARALLELED SUFFERINGS, IS THIS VOLCME MOST RESPECTFCLLY

DEDICATED

BY

IHE AUTHOR 
* Sallow ye each lonely grare, Make their memory sure and bless For their lives they nobly gave, And their spirits are at rest." 


\section{PREFACE.}

IT has been my aim in the preparation of theso pages, to give a plain, unvarnished narrative of facts and incidents of Prison Life, as they occurred under my own observation during an experience of fourteen months, in various Southern Prisons.

They do not pretend to give a complete history of that eventful period-only a part. Others are contributing sketches for the dark picture, which, at the best, can but poorly illustrate the fearful atrocities of our brutal keepers.

The multiplied woes of the battle-field, and the sufferings of the sick and wounded in hospitals which the Federal Government has established, might almost be considered the enjoyments of Paradise, when com. pared with the heart-rending and prolonged agonies of Captives in Rebel Stockades.

Sad and painful as it seems in the former case, there are a great variety of mitigating circumstances which tend to soothe the feelings as we contemplate them. Their sufferings are of comparatively short duration, surrounded as they are by those who 
never tire in their efforts to provide comfort and relief. Members of the numerous humane societies can visit them and attend to their wants; but in the latter case they have passed the boundary which bars them from all these things.

We are even led to conclude, by the usage which we have received at the hands of our captors and brutal prison keepers, that it was their deliberate intention to maim, and thereby render us completely unfit for future service. They have seen us, with apparent satisfaction, become so much reduced in clothing as to have scarcely rags for a covering; they have condemned us to hunger and thirst, pain and weariness, aftliction and misery in every conceivable form, so that thousands of our unfortunate fellows have anxiously awaited the approach of the King of Terrors as the arrival of a welcome messenger that had come to bring them a happy release.

In the absence of much information on this subject, it is impossible for me to give an exact account of the number of deaths in Rebel Prisons. Still, if we consider the statements of several who have reduced their calculations to figures, we may arrive at a more correct conclusion than we otherwise shonld. Robert H. Kellogg, Sergeant-Major, 16th Connecticut Volunteers, who was at Andersonville and Florence, says the deaths at the latter place were twelve per cent. per month. Mrr. Richardson, correspondent 
of the New York Tribune, says it was thirteen per cent. at Salisbury for the same time. There were 13,000 deaths at Andersonville. Mr. Kellogg aftirms that one-half of his regiment captured, died in about seven months. Let us suppose that the prisoners will average 25,000 from January 1, 1862, to January 1,1865 , and the deaths to be nine per cent. per month, or 2,250 ; then multiply by thirty-six months, and we have 81,000 deaths. Had we been provided with such clothing, shelter, and food as the laws of health absolutely require, it is probable that there would not have been more than one-eighth of the actual number of deaths. Hence, we conclude that 70,875 have fallen victims to inhuman treatment. My figures with regard to the number of prisoners, and the percentage of deaths, may be too large; but allowing that my estimates are nearly right, the awful carnage of the battle-field has not exceeded the frightful mortality of the Prison Pen. Whether the Rebels have intentionally murdered our unfortunate soldiers or not, I leave the reader to decide.

I had no thoughts of publishing a book until several weeks after my escape. I kept a diary, or journal, from the time of my capture. After reading portions of it to some of my friends, they persuaded me to amplify and put it in a readable form.

The rough manuscript was, for the most part, written during my imprisonment at Columbia, sit- 
ting on the ground, and writing on my knee. Captain Kelly, 1st Kentucky Cavalry, brought a part of that manuscript through the lines by concealing it in the crown of an old regulation hat. I escaped with the remainder concealed in the lining of my jacket; and though I had the misfortune to be twice recaptured, succeeded, by dint of considerable strategy, in bringing it safely through to Savannah.

The Appendix is principally the work of Robert J. Fisher, late captain 1\%th Missouri Volunteers, being taken from his lithograph, entitled the "Libby Prison Memorial." To these, as well as to those friends who have expressed an interest in the work, and in various ways aided in promoting it, my sir. cere thanks are tendered.

Willard W. Glazier.

Albaxt, N. Y., Norember 12, 1865. 


\section{0 N T E N T S.}

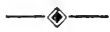

\section{CIIAPTER I.}

The Author's Enlistment and Service in the Field-Federal Defeat at Bull Run-Northern Patriotism-The President's Call-Organization of the Harris Light Cavalry-Ordered to Washington-Encampment at Munson's Hill-At Arlington Heights-McClellan's Advance to ManassasTransfer of the Army of the Potomac to the Peninsula-The Harris Light remains with the Army of Northern Virginia-McDowell's Advance to the Rappahannock-Night Attack at Falmouth-Occnpation of Fredericksburgh-Raids during the Spring and Summer of 1862-General Pope's Campaign in Virginia-Battle of Cedar Monntain-The Peninsular Campaign Abandoned-First Cavalry Fight at Brandy StationBull Run No. 2-The Campaign in Maryland and Pennsylrania-Battle of Fredericksburgh-Death of General Bayard-Defeat of the Black Horse Cavalry-Kilpatrick's Raid around Lee's Army-Second Cavalry Engagement at Brandy Station-Cavalry Fight at Aldie-Middleburgh -Upperville-Second Campaign in Maryland and Pennsylvania-Battle of Gettysburg-Engagement at Boonsboro'-Williamsport-Hagerstown -Falling Watcrs-Lee's Retreat to the Rapidan . . . . . . . .

\section{CHAPTER II.}

The Capture-Situation of the Army of the Potomac in October, 1863-General Meade equal to the Emergency-Action of the Rebels-General Lee's Flank Movement-Cavalry Fight at James City-The Army retires to Manassas-Cavalry Fight at Brandy Station-The Grand Charge-Gallant Conduct of Generals Kilpatrick and Davies-The Rebel Lines brokenKilpatrick joins Buford-A third Engagement anticipated on the old Bull Run Battle-field-Great Alarm cansed by the Accidental Burning of an Ammunition Wagon-Preparations for Battle-The Battle of Bristoe The Federal Arms Victorious-A Reconnoissance-Horses and Men Drowned while Fording Bull Run-Slirmishing with Rebel Cavalry, October 18th-Cavalry Fight at Buckland Mills-The Author's Horso shot ander him-His Capture and Lodgment in Warrenton Jail-Robbing Prisoners-March from Warrenton to Culpepper-Sufferings of the Prisoners-Incidents at Culpepper-Remoral to Orange Court HouscAt Gordonsville-Registering Names-The Drunken Guard-An Issue of Rations-From Gordonsville to Richmond-October 19 to October 23, $1 \$ 53$ 


\section{CHAPTER III.}

Arrival in Richmond-Libby Prison-First Impressions-General Search for Greenbacks and other Valuables at Major Turner's Office-How the Anthor concealed his Journal-Meeting the old Prisoners-Description of the Prison-Character of Major Turner-Exchange Rumors-October 23 to November 8,1863 . . . . . . . . . . . . . 41

\section{CIIAPTER IV.}

In the Hospital at Libby-Prevailing Diseases-Eebel Surgeons-Rations for the Sick-Exchange of Surgeons-Sending Messages to Friends at the North-Old Newsboy, Ben-Thanksgiving-Day in Libby-Invisible Ink-The Rebels Discover the Secret-Detention of a Love-Letter-The Dead-House-Escape of Dead Yankees-A Rebel Surgeon Outwitted by a Yankee Tailor-Sad News from Home-Bragg's Defeat-Plans for Escape-Keyhole Correspondence -Belle Isle-Amusements-An Escape and its Consequences-Barbarous Treatment of the Sick-November 8 to December 16,1863 . . . . . . . . . . . . .

\section{CHAPTER V.}

Return from the Hospital-An Order from General Winder-More Exchange Rumors-The New Year in Libby-Daily Allowance of Rations-Punishment for Singing our National Songs-Captains Sawyer and FlynnJohn MIorgan, the Rebel Raider, visits Libby- The "Great Yankee Tunnel"-Plan of Operation-Implements used-Disclosing the SecretStripping for the Chimney-Escape of Prisoners-The Guard in Castle Thunder-Roll-call-Discovery of the Tunnel-Rebel Accounts-Kilpatrick's Attempt to release the Prisoners at Richmond-Death of Colonel Dahlgren-Rebel Mode of treating Captives from Kilpatrick's Command -The Prison Undermined-A Special Exchange-"Exchange on the Brain "-Arrival of Prisoners from Plymouth, N. C.-General Wessels -Mosby, the Rebel Gnerrilla, visits Libby-Great Commotion in Richmond-General Lee reported to be defeated-Notice from Major Turner to be ready to leave the Prison-Each Man receives a "Corn Dodger "-

Farewell to Libby-December 16,1863, to May 7,1864 . . . . . . . .

\section{CHAPTER VI.}

Arrival at Danville-The Journey-Escapes from the Cars-Firing upon Prisoners-An Attempt to disarm the Guard-Military Importance of Danville-Rations-Sleeping Spoon-fashion-News from the ArmyTunnelling commenced-General Averill's Raid-Joy of the PrisonersUneasiness of the Rebels-Once more on the Rail-From Danville to Macon-Meeting Conscripts for Lce's Army-Marching in North Carolina Mud-The Author's Attempt to escape-In Box-cars again-An Unpleasant Situation-Arrival at Charlotte-Singing the "Star-Spangled Bamner"-Loyalty of the Citizens-An Issue of Rations-Attempts to 
escape-Climbing Trees and digging Holes in the Ground-Amusing Incidents-From Charlotte to Columbia, South Carolina-From Columbia to Augusta, Georgia-From Augusta to Macon-May 7 to May 17,1861

\section{CHAPTER VII.}

At Macon, Georgia-"Camp Oglethorpe"-Major Turner at Macon-The "Dead Line"-Firing upon a Prisoner-New Arrivals-Rations-Digging Tunnels-Tunnels Discovered by the Rebels-Punishment-Appeal to Captain Gibbs-Murder of Lleutenant Grierson-Rebel Favors-New Tunncls-Plans for Escape Frustrated-Sentinels Instructed to shoot Prisoners-Special Orders No. 6-Personal Attack of the Scurvy-Fourth of July in the Prison Pen-Music, Speeches, Toasts, etc.-The Miniature Star-Spangled Banner-The Prison Aathorities March in a Battalion of Armed Men and Compel ns to Disperse-Special Orders No. 9-The Author's Illness-Selling Buttons to save Life-Removal of Prisoners-May 17 to July 29,1864 . . . . . . . . . . . . . . . 113

\section{CHAPTER VIII.}

Sarannah, Georgia-“Camp Davidson "-General Stoneman's Raid-Kind Treatment at Savannah-A Comparison of Rebel Prisons-Better Rations -Brick Ovens-Tunnelling-Our Scheme Exposed by a Cow-Joy without Death within the Stockade-Inhumanity of Colonel Wayne-" Nothing but a Damned Yankee"-Kindness of Ladies-Amusements-The Pursuit of Knowledge under Difficultics-Off for Charleston-July 29 to September 12, 1864

\section{CUAPTER IX.}

At Charleston-"Under Fire "-Arrival in the City-Our March down Coming Street-In the Jail Yard-Charleston Jail and its Immates-Sufferings of the Negro Prisoners-A Friend-Inclined to be Distrustful-An Act of True Nobleness-Genuine Patriotism-A Higher Language than the Written-The Last Visit-Negro Melodies-Meeting Prisoners from Andersonville-Their Stories-The Ground a Mass of Lice-Awiul Condition of the Hospital-Great Suffering-Living Death-A Captain recognizes a Member of his Compauy just at the point of Death-Prisoners Die after being told they are not in need of Medical Treatment-A Thunder Storm-Refused Admission to the Jail-September 12 to September 29,1864

\section{CHAPTEP $\mathrm{X}$.}

Roper Hospital-The Parols-Better Prospects-The Burnt District-Shells a Subject of Discussion-Morris Island-The Swamp Angel-Shelling the City - Sisters of Charity - Yellow Fever-Our Enlisted Men on Charleston Race Course-Orders to "Pack up "-General Foster"s Retaliation has a Good Effect-Farewell to Charleston-Poem bJ Lientenant J. Ogden-September 29 to October 5, 1864 . . . . . . . . . i:, 


\section{CHAPTER $\mathrm{SI}$.}

Remoral to Columbia, South Carolina-Description of the Journey from Charleston-Cattle Cars Defined-Kindncss of the Guard-Arrival at Columbia-Bayoneting a Prisoner-A Terrific Rain Storm-Peace Movements-Practical Infamy of the Rebels-They urge the Prisoners to take a Parole-Threatened with Confinement in old Tobacco Houses . . 163

\section{CHAPTEP XII.}

"Camp Sorghum "-News from the Army-An Issue of Clothing received from our Sanitary Commission-Joy of the Prisoners-The Presidential Election-Political Discussions-Manner of Voting-The Result-An Escape-A Prisoner Shot-Rebel Eloquence- "Long Live the Dutchman" - "Rum" deprives him of Authority-Thoughts of Home-Allowed to get Wood by taking a Parole-Turning Night into Day-A Prisoner caught by Hounds-Drawing Meat Ration at "Camp Sorghum "-Gorernor Brown's Proclamation-Heavy Frosts-No Blankets-Sleeping in the Middle-No Prospect of an Exchange-Renewed Determination to Escape-October 6 to November 26, 1864 . . . . . . . . . 175

\section{CHAPTER XHII.}

The Escape from Columbia-Ny Companion-Halted by the Guard-Acting the Part of paroled Prisoners-Passing the "Dead Line"-Neeting Negroes-Travelling with a guide--Blind Roads-Challenged by a Picket_. "I dun no what make dem Niggers run so"-Ingenuity of our Guide-Picket Reserve-Searching for my Companion under Difficulties-Subsisting upon Blueberries-Appealing to SympathyKindness of Mrs. Taylor-A Negro Prayer-meeting-How we secured a Paper-Crossing the North Edisto-The Road terminates in a SwampOther Difficulties-My Companion's Misfortune-Pursued by Bushwhackers-Meeting Escaped Prisoners at Aiken-Approaching a Negro -Concealed in a Corn-fodder House-An Attempt to travel by RailWe hear Cannonading-Greatly encouraged-Followed by a Hound-A Happy Mistake-Crossing the Savannah in a Cypress Canoe-Bailing for Iife-Alligators-The North Star-Cavalry Patrol-A Negro Cobbler repairs the Author's Shoes-November 26 to December 11, 1864 . . .

\section{CHAPTER XIV.}

Following the Rebel Army in Georgia-Fording Streams-We run to prevent Chilling-Striking the Trail of the Armies-Appearance of the Country-Pursued by Hounds-Narrow Escape from Fire-Interview with a Planter-He thinks the Author a Rebel Officer-Rations in the Pantry-Inquiring for General Wheeler's Cavalry-We obtain all the Particulars-Meeting Negroes-" De Planter was a Bushwhacker "-Unpleasant Predicament-Meeting a Rebel Officer by Accident-My Horse 
Bhot at Waynesboro'-My Regiment the Third South Carolina CavalryDiscussing Present Prospects-The Proposed Meeting at Mir. Brown'sRoasting Corn-Accidentally seen by a Planter-A Critical SituationHounds on Track-Flanking a Picket-Duping Rebel Couriers-Crossing Big Ebenezer Creek-Burying one of our own Soldiers-A dashing Ride on Horses left by the Rebel Couriers-Concealed near a Pickut-December 11 to December 16, 1864 . . . . . . . . . . . . 2

\section{CHAPTER XV.}

Re-captured by a Rebel Picket-The Challenge-Arrival at the Reserve of the Picket-Regarded as a Yankee Spy-Kindness of a Rebel SoldierAn Attempt to bribe the Guard-"Let 'em stretch Hemp "-Apparently unable to Walk-Once more in the Saddle-The Escape and PursuitRecaptured by Texans-At General Wheeler's Head-quarters-Confinement in the County Jail at Springfield, Georgia-December 16 to December 20,1864. . . . . . . . . . . . . . • 257

\section{CIIAPTER XVI.}

The Escape from Sylvania, Georgla-The Plan-Taking Rations intended for the Rebel Guard-Hounds to be put on Track-Confiding our Plans to a Negro-Concealed in an old Pine-tree Top-In a Swamp near Springfield-Rebel Deserters-The Interview with Mrs. Keyton-Turning the Tables-Ill-fated Dixie-General Sherman just where they wanted himStartled by Hounds-Bushwhackers in Pursuit-A Narrow Escape-An Amusing Incident-Efforts to obtain a Guide-Colored Man No. 3- "I'll do it, Massa, if God be my Helper "-Approaching the Outpost-Within the Federal Lines-December 20 to December 24, 1864 . • . • . $2 \pi 7$

\section{CIIAPTER XVII.}

Homeward Bound-Arrival at Savannah-Not easily Identified-Regarded as Spies-Pronounced Genuine Union Soldiers-Unsettled State of the Army-Wright succeeds in finding his Regiment after a long SearchKindness of Captain Swallow-My Christmas Dinner-At Kilpatrick'z Head-quarters on the Ogeechee River-Return to Savannah-Furnished Transportation to New York-On Board the Steamship Planter-Transferred to the Delaware-Arrival at Hilton Head-On Poard the Ashland -In a Gale off Cape Hatteras_Sea-sickness-Arrival at New York-Desember 24, 1864, to January 4, 1865 . . . . . . . . . . 301

\section{CHAPTER XVIII.}

Gelections from the Files of the Libby Chroncle-Prospectus-Kansas Brigade's Version of John Brown-South Window, No. 1-Conundrums -Castle Thunder, in Three Parts, a Poem-News of Libby-South Win- 
dow, No. 2-The Libbyad, a Poem-Who is Responsible for Non-Exchange of Prisoners-South Window, No. 3-The Soldier and the Gentleman-The Irruption, a Poem-The Beautiful-Light and Shades in Libby-Adrertisements-The Mock Trial . . . . . . . . . . 318

\section{CHAPTER XIX.}

At Millin-Testimony of Sergeant W. Goodyear-The Inclosure-Arerage Number of Deaths per Day-Daily Allowance of Rations-Excitement at the Presidential Election-Inducements to enter the Rebel Service . . . 3it

\section{CHAPTER XX.}

Salisbury Prison-Experience of Mr. Richardson-Great Suffering for want of Bread and Shelter-"Give them Quarter Rations"-Terrible Condition of the Hospitals-Salisbury Penitentiary as viewed by Mr. Brown-The Prisoners dricen to Desperation . . . . . . . 362

\section{CHAPTER XXI.}

At Andersonville-Testimony of Ira E. Forbes-His Capture and Removal to Camp Sumter-Traffic with the Rebels-Generosity of the Citizens of Charleston-Arrival at Andersonville-Captain Wirz-The "Dead Line" -Shooting Prisoners-Frightful Mortality-Burial of the Dead-Intense Mental Trials--Ravages of Scurry-Awful Condition of the HospitaRemoval of Prisonera to Florence, South Carolina-The Andersonvilla Post-Office-Rations Issued by the United States Government to Rebel Prisoners of War-Statement of Clothing Issued to Rebel Prisoners ef War at Fort Delaware . . . . . . . . . . . . . 362

\section{A P E EDIX.}

Containing the Name, Rank, Regiment, and Post Office Address of the Oflcers who were imprisoned at Richmond, Danville, Macon, Savannah, Charleston, Columbia, Cherlotte, Raleigh, and Goldsborough, 1864 and 1365 . . . . . . . . . . . . . . . . . 891 


\section{等ist of}

PAGB

1. Portrait of the Author, - - - - - - - Frontispiece.

2. The Capture-Cavalry Fight at Buckland Mills, - - - - - 35

3. Libby Prison, - - - - - - - - - - - - 49

4. Interior View of Libby Prison, - - - - - - - - 71

5. The Hole in the Floor, - - - - - - - - - - 91

6. Tunnelling-The Narrow Path to Freedom, - - - - - - 117

7. Jail Yard, Charleston, South Carolina, - - - - - - - 145

8. Rebel Mode of Capturing Escaped Prisoners, - - - $\quad$ - $\quad 183$

9. The Escape from Columbia, South Carolina-Crossing the Dead Line, - 199

10. The Escape-Crossing the Savannah at midnight, - - - 231

11. The Escape-Fed by Negroes in a Swamp, - - - - - - 243

12. Recaptured, - - - - - - - - - - - - 261

13. The Escape and Pursuit, - - - - - - - - - - 269

14. The Escape from Sylvania, Georgia, - - - - - - - 283

15. Approaching the Federal Lines, - - - - - - - - 307

16. Came too near the Dead Line, - - - - - - - - 359

17. Interior View of the Andersonville Prison, - + - + - - 573 



\section{PRINCIPAL REBEL PRISOIS, AYD WIIERE THEY WERE LOCATED.}

LiBby, Richmond, Virginia.

Castle Thudder, Richmond, Virginia.

Daxrille, Spottsylvania County, Virginia.

Belle IsLe, in James River, near Richmond.

MAcon, Georgia, known south as Camp Oglethorpe.

Savaxian, Georgia, known south as Camp Davidson.

Andersonville, Sumter County, Georgia, known south as Camp Sumter.

Mrillis, Burke County, Georgia, known south as Camp Lawton.

Charleston, South Carolina.

Colcaria, South Carolina.

Blackstone, South Carolina.

Florexce, Darlington County, South Carolina.

Salisberr, Rowan County, North Carolina.

Raleigi, North Carolina.

Goldsborodgh, North Carolina.

Charlotte, North Carolina.

Trler, Smith County, Texas.

Camawba, Dallas County, Alabama 



\section{THE CAPTURE,}

T H E

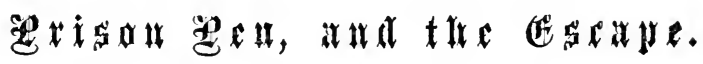

\section{CHAPTER I.}

ENLISTMENT, AND SERVICE IN THE FIELD.

THe first battle of Bull Run was fought July twenty. first 1861, and the shock of arms was felt throughout the land, carrying triumph to the South and to the North dismay. Our proud and confident advance into "Dixie" was not only checked, but turned into a disastrous rout. The patriotic, but unwarlike, enthusiasm of the country, which had hoped to crush the Rebellion with seventy-five thousand men, was temporarily stifled. But the chilling was only like that of the first stealthy drops of the thunder-gust upon a raging fire, which breaks out anew and with increased vigor when the tempest fans it with its fury, and now burns in spite of a deluge of rain. The chill had passed and the ferer was raging. From the great centres of national life went forth warm currents of renovating public opinion, which reached the farthest hamlet on our frontiers. Every 
true man was grasping the stirring questions of the day, and was discussing them with his family at his own fire-side, and the Rebellion was just as surely doomed as when Grant received the surrender of Lee's army. In a deeper and broader sense than before, the country was rising to meet the emergency, and Northern patriotism, now thoroughly aroused, was sweeping every thing before it. Everywhere resounded the cry, "To arms!" and thousands upon thousands were responding to the President's generous call.

It was under these circumstances that I enlisted, as a private soldier, at Troy, New York, on the sixth day of August, in a company raised by Captain Clarence Buel, for the Second Regiment of New York

\section{HARRIS LIGHT CAVALRY.}

It is needless to make elaborate mention of the motives which induced me to enter the service, or the emotions which then filled my breast; they can be readily conjectured by every loyal heart.

The Harris Light Cavalry was organized by $\mathrm{J}$. Mansfield Davies, of New York, as colonel, assisted by Judson Kilpatrick, of New Jersey, as lieutenantcolonel.

Up to this time it had been no part of the policy of the Government to increase the cavalry arm of the service. General Scott had trusted entirely to infantry, and his counsel and example were still potent. Bull Run, however, had demonstrated the éfliciency of cavalry, aud the authorities began to change their 
views. To match the famous Black Horse Cavalry of Virginia, it was proposed to raise a cavalry force in the North, and as Senator Ira Ilarris, of New York, was giving this organizatian his patronage and influence, a brigade was formed whose banners should bear his name. The Harris Light, to which I belonged, was composed of men from New York, New Jersey, Connecticut, Vermont, Pennsylvania, and Indiana. It was originally intended for the regular army, and was for some time known as the Seventh United States Cavalry, but this branch of the service having been reduced to six regiments, we were assigned to New York, as she had contributed the largest number of men to the organization.

During the latter part of August, we were ordered to Washington, and, after a montl's drill, crossed the Potomac and encamped in front of the enemy at Munson's Hill.

\section{MCCLELLAN'S ADMINISTRATION.}

McClellan was then chief in command, and all was quiet along the Potomac until spring. The winter was spent in drilling, and the Rebel General Lee's plantation on Arlington Heights and the surrounding country was thoroughly trodden by loyal feet, as men and horses were learning the tactics of war. Thus the foundation of a career destined to be important and glorious was laid, and the discipline imparted to the army was of incalculable service in after campaigns.

The grand advance of the Army of the Potomac legan March third, 1862, and resulted in the capture 
of the "Quaker guns" at Centreville. In this daring campaign the Harris Light was honored with the position of body-guard to McClellan. Bearing its recently earned laurels, the army then fell back to its old position and held a council of war, and shortly after the main portion of it was embarked for the memorable Peninsular Campaign. General McDowell was left in command of Northern Virginia, with a small force, whose chief design was to defend Washington, but which rendered good service in harassing the enemy still remaining in our front.

\section{NIGHT ATTACK AT FAIMOUTH.}

About the first of April, MIcDowell advanced with the small force left in his command, to reconnoitre the position and power of the enemy. Colco nel-afterwards General-Bayard, was in command of the cavalry, which consisted only of the Harris Light and the First Pennsylrania. Sereral days were spent in feeling the front of the enemy, each side becoming gradually familiar with the changed circumstances of affairs, though neither seemed disposed to take a hasty step which might prove advantageous to the other. This cautious kind of policy was, however, disturbed by the apparently reckless daring of General-then Colonel-Kilpatrick. The enemy was strongly intrenched at Falmouth Heights, and he asked permission to surprise them in the night. After much persuasion, leare was granted, and, at the head of our small regiment alone, he undertook the work. Stratagem, of course, was the only alternative, and as we approached the works, under cover of 
the darkness, to within hearing of the Rebel pickets, Kilpatrick shouted to his command,-

"Bring up your artillery in the centre, and infantry on the left!"

"Well, but, Colonel," replied an honest, though rather obtuse captain, "we haven't got any-"

"Silence in the ranks!" shouted the commander. "Artillery in the centre, infantry on the left!"

The pickets caught and spread the alarm, and the heights were carried with little opposition.

The early part of summer was spent mostly in raiding and reconnoitring. Expeditions were sent in every direction, but more especially toward Richmond. Railroads and telegraph lines were destroyed, and commissary stores in large quantities. Thus the cavalry found enough both of war and romance. Indeed, "we picket our outposts, scout the whole country for information, open our fights, cover our retreats, or clear up and finish our victories, as the case may be. In short, we are never idle, and rarely find rest for either men or horses."

\section{POPE'S CAMPAIGN IN NORTHERN VIRGINIA.}

In July, 1862, General Pope took command of the troops in Virginia, and soon after fought the battle of Cedar Mountain. A battalion of the Harris Light was McDowell's body-guard during the engagement.

McClellan having concluded his campaign on the Peninsula, re-embarked his decimated troops for Washington, while Lee forsook his fortifications in. the vicinity of Richmond, and soon confronted Pope on the old Bull Run battle-ground. While these prep. 
arations were being made, occurred the first cavalry fight at Brandy Station, in which the Harris Light lost heavily.

After our second disaster at Bull Run, the cavalry covered the retreat to Washington, checking the advance of the Rebels, and covering the flanks and rear of our demoralized army. This necessitated continual fighting with the enemy's caralry and with the vanguard of their infantry.

By the almost continual fighting of the summer campaign, with almost ceaseless marching and picketing, our ranks were sadly depleted; consequently we were ordered to Hall's Hill, eight miles south of Washington, to recruit our wasted strength and numbers.

Our stay, however, was of short duration, for by the first of November, we were again moving to the front, under command of General Bayard, and for nearly one month our boys were an the picket-line, preparing the way for the disastrons

\section{BATTLE OF FREDERICKSBLRG,}

which commenced on the thirteenth of December, and continued to the sixteenth, when General Burnside, with his whole army, was forced to recross the Rappahannock. On the first day of the engagement, General Bayard fell mortally wounded by a solid shot, and thus baptized, with his heart's blood, the very day which had been previously appointed for his nuptials. This young and gallant officer was nniversally lamented. After the battle, winterquarters were established, and the two armies passed 
the stormy scason watching each other across tho narrow river, the cavalry, as usual, occupying the extreme front.

The spring campaign of 1863 was opened with the usual eavalry raids and reconnoissances. On the seventeenth of April, a squadron of the Harris Light was ordered from Bealeton to Warrenton, with instructions to occupy the town till four o'clock P. Mr. On arriving near the village we ascertained that the famous

\section{BLACK HORSE CAVALRY}

held possession, and from their world-wide reputation, we expected they would give us a splendid entertainment. The boys were all eager to cross sabres with these heroes of Bull Run, and hasty preparations were made for the attack. Our small force was divided into two parties, with orders to enter the village from opposite directions. On entering the town, we found the foe formed in battle array, our approach having been discovered by a picket, stationed in a church steeple. Immediately we drew sabres, and bore down upon them with a yell. They advanced to receive us, fired a few shots, unsheathed their bloodless sabres, and, strange to say, wheeled about and dashed away to the rear at a break-neck pace, without even halting to pay us the compliment of an affectionate farewell.

They were undoubtedly seized with the spirit of the muse who sings:

"He who fights and runs away, Will live to fight another day." 
During the winter, General Hooker was appointed commander of the army, and great preparations were made for a vigorous campaign. Much ot the efficiency of the cavalry in subsequent movements, was largely due to Hooker, who organized it into a distinct corps, and gare it new inducements and means to success.

On the twenty-seventh of April, the army again crossed the Rappahannock, and the bloody battle 'sf Chancellorsville was fought. General Stoneman commanded the caralry corps, and, during the battle, he not only turned the enemy's position, but also cut off their communications in the rear. Meanwhile occurred

KILPATRICK'S RAID AROUND LEE'S ARMY.

This intrepid leader, breaking away from the main body of cavalry with his regiment, galloped entirely around Lee's army, passed within the second line of fortifications around Richmond, frightened terribly the Home Guards of the chivalry, swooped around, like an eagle, through Yorktown and back to Brandy Station, in time to participate in the second fight there, on the ninth of June. This was thought to be the largest and most stubbornly contested caralry battle of the war.

Lee, at this time, was marching up the Shenandoah Valley, and our cavalry, under General Pleasan. ton, was guarding the supply-train in the rear of our army, and fighting the Rebel General Stuart through the many gaps of the Blue Ridge.

During this advance were fought the battles of $\mathrm{Al}$. 
die, Middleburgh and Upperville, all severe contests, in which it was proven that Northern men could be heroes on horseback, as well as on foot. Immediately on the heel of these battles came the general engagement of Gettysburgh, during which time our caralry held Stuart and his command well at bay, while they harassed not a little the enemy's flank and rear.

On the night of July fourth, Kilpatrick, then commanding a division, captured Longstreet's entire wagon-train, laden with the ripe crops of Pennsylvania and Maryland, and with the plunder of private and public stores, together with fourteen hundred prisoners, in spite of Stuart's most vigorous defence, and subsequent efforts at recapture.

During Lee's retreat from soil where he had never been successful, Kilpatrick and Stuart were almost daily in conflict. Hagerstown, Boonsboro', and Williamsport, were scenes of hard-fought battles, and attack followed attack almost incessantly, until Lee's staggering rear was bagged while endeavoring to cross the Potomac at Falling Waters, on the fourteenth of July.

We then followed up the great Rebel raider until he halted on the south bank of the Rapidan. Here picketing and sharpshooting continued but a few weeks, and were followed by brilliant and disastrous movements, which the following chapter will relate. 


\section{CHAPTER II.}

\section{THE CAPTURE.}

Is the early part of October, 1863, the Army of the Potomac encamped along the Rapidan, seeking rest from the arduous labors of the Pennsylvania campaign.

From April till September the contestants had been almost constantly engaged, each endearoring to deal the fatal blow that was intended to drive its antagonist back either upon Richmond or Washington. Public feeling, both North and South, had been wronght up to its highest pitch. General Meade, it was hoped by the loyal, would prove himself equal to the emergency, and many prayers ascended daily for him and his noble army.

The season was well nigh consumed, and yet no decisive results rere apparent. True, the Rebel invasion of Pennsylvania had proved a great failure, and Gettysburg had been a bloody turning point of the Rebellion. The ranks of Lee's army had been somewhat thinned by desertions, and much shattered by unprecedented casualties in battle. Nevertheless he still presented a strong and daring front, indicative of much unwasted energy. On our side active preparations were in progress for a renewal of the struggle. Picket lines along the front were re-enforced, with or. 
ders to be unusually vigilant. Reconnoissances were frequent, and scouts were busy in every direction, and a general advance was confidently expected. But just on the ere of morement, intelligence was received that Lee had very suddenly withdrawn the main force of his army from the line of the Rapidan, and was making a rapid flank morement, which threatened the occupation of the plains of Manassas, before Meade could reach them. Swift couriers, from officers high in command, brought orders to retire with promptness, but in good order, if possible.

CAVALRY FIGHT AT JAMES CITY.

All the cavalry pickets along the Robertson and Rapidan rivers were withdrawn early on the morning of October ninth, with orders to concentrate at James City. The following morning witnessed a severe and bloody fight, which continued with unabated fury and slaughter until eight o'clock at night, when the contending squadrons sought repose from their work of death.

With the first pencillings of the morning light of the eleventh, we took up our line of march towards the Rappahannock. Skirmishing afforded the music of the march. On the Sperryville pike to Culpepper, the Rebels pressed us closely and vigorously. At this point the cavalry corps separated, Buford with his division falling back by way of Sterensburgh, Gregg by Sulphur Springs, leaving Kilpatrick on the main thoroughfare along the railroad line.

No sooner had Kilpatrick moved out of Culpepper than Hampton's division of cavalry made a furious 
attack upon the Harris Light, acting as rear-guard, with the evident design of breaking through upon the main column to disperse or delay it, so as to enable a flanking force to intercept our retreat. Gallartly repelling every attack, the command advanced to

\section{BRANDY STATION;}

where an accumnlation of formidable difficulties threatened our annihilation. Fitz Hugh Lee with the flower of the Rebel cavalry had possession of the only road upon which it was possible for Kilpatrick to retire. Stuart, at the head of another column of caralry, supporting artillery well posted on a long line of hills, completely corered our left. Our right was exposed to a galling fire from sharp-shooters hidden behind the forest trees, while just behind us were Hampton's legions predicting speedy destruction to their surrounded foe.

\section{THE GRAND CHARGE.}

This was a situation to try the stoutest hearts. Nothing daunted, howerer, by this terriffic array of an enemy very superior in numbers, Kilpatrick displayed that decision and daring which have erer characterized him as a great caralry leader, and proved himself worthy of the brave men who composed his command. His preparation for the "grand charge": was soon completed. Forming his division into three lines of battle, he assigned the right to General $H$. E. Davies, jr., the left to General Custer, and, placing himself in the centre, adranced with terrible determination to the contest. Having approached to within a 
few hundrea yards of the enemy's lines, he ordered his band to strike up a national air, to whose spiritstirring strains was joined the blast of scores of bugles ringing forth the charge. Brave hearts became braver, and faltering ones waxed warmer and stronger, until pride of country had touched this raging sea of thought and ernotion, kindling an unconquerable principle that emphatically affirmed every man a hero unto death.

Fired to an almost divine potency, with a majestic madness this band of heroic troopers shook the air with their battle cry and dashed forward to meet their unequal foe. With his usual daring, Davies was foremost in the fray, leading his command for the fourth time on this memorable field.*

To his command he addressed these stirring words: "Soldiers of the First Brigade! I know you have not forgotten the example of your brave comrades, who in past engagements here were not afraid to die in defence of the old flag."

So swiftly swept forwurd this tide of animated power, that the Rebel lines broke in wild dismay before the uplifted sabres of these unflinching veterans, who, feeling that life and country were at stake, risked them both upon the fearful issue. Kilpatrick thus escaped disaster, defeated his pursuers, and presented to the beholders one of the grandest scenes ever wit: nessed on the Western continent.

"By Heaven! it was a splendid sight to see,

For one who had no friend or brother there."

* The fir $;$ battle of Brandy Station was fought August 20, 1862 ; the second, June 9 th ; the third, September 12th ; and the fourth, October 11, 1863. 
No one who looked upon that wonderful panorama can ever forget it. On the great field were riderless horses and dying men; clonds of dirt from solid shot and bursting shell; broken caissons and upturned ambulances, and long lines of cavalry dashing in the charge, with their drawn and firmly grasped sabres glistening in the light of the declining sum, while far beyond the scene of tumult were the dark green forests skirting the banks of the Rappahannock.

Kilpatrick soon after joined Buford, and together they engaged the enemy in a series of brilliant charges which materially checked his pursuit, and at night we crossed the Rappahannock in safety.

The army continued to retreat to the old field of

BULL RUN,

where it was expected a third battle would be fought.

On the twellth of October a portion of our infantry having recrossed the Rappahannock, made a forced march to Brandy Station, where a spirited engagement took place. The movement was probably nothing more than a reconnoissance, or an intention to deceive the enemy.

On the following evening, while bivouacking not far from Bealeton, an amusing scene diverted for a time the attention of the boys. By accident an ammunition wagon took fire, causing the rapid explosion of its contents. The consequence was a wide-spread alarm, which brought every trooper to his horse, ready to engage the foe, who was supposed to have made a 
furious onset! Merriment and rest followed the discovery of the disturbance.

Closely pursued by the enemy, our army continued its retreat until late in the afternoon of the fourteenth when a general halt was ordered and preparations made for battle.

At early dawn of the fifteenth the thunder of our zrtillery at Bristoe announced Meade's intention to fight, and opened an engagement which gare the enemy a disastrous repulse, effectually checking his advance, which thus far had met but little resistance.

On the following day, while Kilpatrick was making a reconnoissance in force, a terrific rain-storm having swollen the streams to a great height, several men and horses were drowned while endeavoring to ford Bull Run. Skirmishing, picketing, and scouting, kept Kilpatrick's forces busy until the nineteenth of Ootober, when was fought the spirited

\section{CAVALRY FIGIT AT BUCKLAND MILLS.}

At daybreak Kilpatrick left Gainesville en route for Warrenton. Stuart's cavalry, which had picketed in our front through the night, immediately retired from before us, and, to our surprise, made no resistance to our advance. We followed him quite closely until our advance had just passed New Baltimore, when Fitz Hugh Lee, who had surprised and cut his way through a small detachment of our infantry at Thoroughfare Gap, fell upon our rear-guard at Buckland Mills, and opened upon it with a battery of flying artillery. At this signal, Stuart, who had hitherto been quietly retiring, now turned and $2 *$ 
charged us in front. General Gordon, whose command was carefully concealed until now, appeared on ouir left, and made a furions attack, which threatened to serer the two small brigades which composed Kilpatrick's division.

This was a critical situation, but "Kil" (as the general was familiarly known) seemed to comprehend it in a moment. He ordered his whole force to wheel about and to charge back on Lee's columns. This timely order, executed with masterly skill, saved his command from utter disaster. The Harris Light, having been in front while advancing, by this sudden evolution was thrown in the rear, and was thus compelled to meet the desperate charges of the enemy in pursuit. Reaching a little rise of ground in the road, we made a stand, and for some time checked the adrancing Rebels, by pouring into their ranks deadly volleys from our carbines and revolvers. Stuart, who commanded in person, saw clearly that he could dislodge us only by a charge, and, ordering: it, led a brigade upon us. Our men stood firmly, and were soon engaged in a hand-to-hand conflict with their adrancing columns.

\section{THE CAPTERE.}

At this important juncture, my faithful horse was shot under me, and our little party, outnumbered ten to one, was hurled back by the orerporrering shock of the Rebels, who rode directly orer me. Injured severely by the fall of my horse, and by the charging squadrons that trod upon me, I lay in the mud for some time quite insensible, and, when re. 


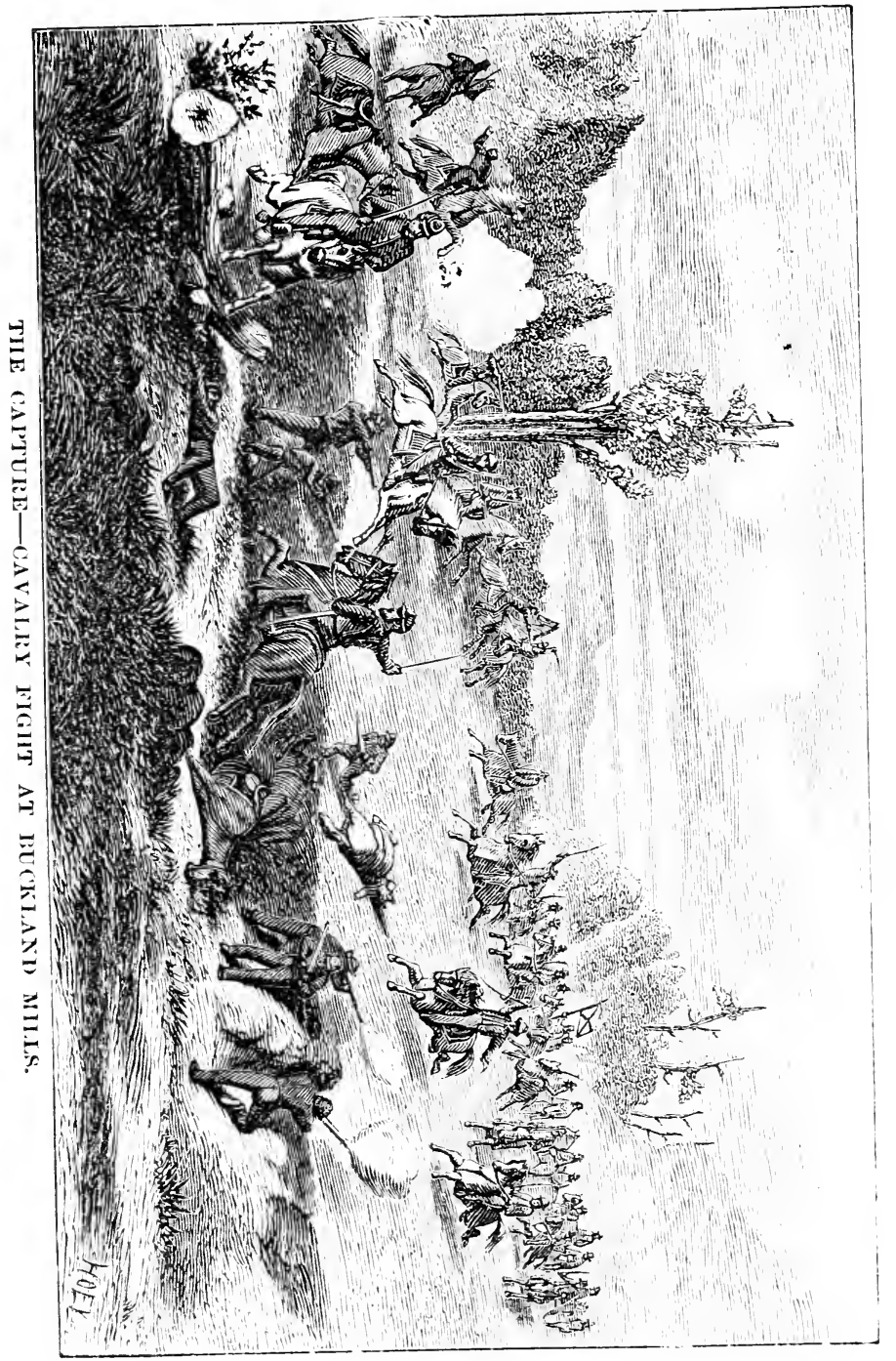



turning to full consciousness, found that I was being carried hastily from the scene of action by a Rebel guard. My arms had been taken from me and my pockets rifled of all their valuables, including my watch. I was borne to a spot near an old building, where I met a number of my comrades who, with me, had shared the misfortunes of the day.

Here we witnessed an amusing exhibition of Rebel bravery. The woods in the vicinity were full of skulkers, and, in order to make a show of having something to do, they would make their appearance in the rear of the fighting columns and derote themselves sedulously to guarding the prisoners. Privates, corporals, and sergeants in succession had us in charge; each in his turn would call us into line, count us in an officious manner, and issue orders according to his liking, until some sneak of higher rank came along, assumed command and said in a tone of authority to the others, "Gentlemen, your services are much needed at the front; go and do your duty like soldiers." This was said with chattering teeth and anxious glances in the direction of our cavally.

\section{IN WARRENTON JAIL.}

Thus we were guarded and goaded by one coward after another-each styling himself "Assistant Deputy Provost Marshal "-until evening, when we were marched to the county-seat and lodged in the Warrenton Jail. During the night, most of the prisoners were robbed of their clothing and valuables by the guards, and in fact every thing was taken which could be of the slightest value. One of these "chivalrous 
gentlemen," whose "vaulting ambition generally o'erleaped itself," demanded my entire wardrobe, when the following conversation ensued:-

Reb. "Here, Yank, hand me that ar hat, and come out of that overcoat and them ar boots too, you d-d blue-jacket."

Fed. "The articles you demand are my personal property, and you have no right to take them from me."

Reb. "We have authority from General Stuart to take from prisoners whaterer we $\mathrm{d}-\mathrm{n}$ please."

Fed. "I doubt your authority, sir, and if you are a gentleman you will not be guilty of stripping a defenceless prisoner."

Reb. "I'll show you my authority, you d-d blue belly" (drawing his revolver). "Now take off that ar" cuat, or I'll blow your brains out."

Fed. "Blow away, then; it's as well to be withont brains as withont clothing."

Johnny Reb. was not quite disposed to fire upon me, and, giving his head a shake, walked away, thinking, no doubt, that he could supply his wants in another direction without wasting his ammunition.

\section{REMOVAL TO CULPEPPER.}

On the morning of the trrentieth, before sunrise, we started for Culpepper. This was one of the severest tramps of my life. The weather was exceedingly warm, and the distance about thirty miles. Our guards rere mounted, and evinced but little sympathy with us in our unfortunate condition, as we endeav. 
ored to keep pace with them. Our forced march was owing to the fact that Lee's army, defeated at Bristoe. and afterward at Rappahannock Station, was retreating rapidly to its strongholds on the Rapidan, with our forces in pursuit. It was a relief to our weary minds to hear of the success of our old companions, fiom whom we had been so recently and rudely torn, and to reflect on the peculiar fortunes of war, as seen during the campaign now about to close.

In June last, the great armies swung like a mighty pendulum from the Rappahannock, Virginia, to the Susquehanna, Pennsylvania, then back to the Rapidan, afterwards to the Potomac, and now to the Rapidan again. It is very encouraging to notice that the swing of the Rebel army northward shortens at every move, giving indications of its waning power. With such cogitations we solaced ourselves by the way, and yet none, save those who have passed through the same experience, know how to sympathize with a captured and dismounted cavalier on a march. We were not only unused to this mode of locomotion, but were encumbered with heavy, high-heeled cavalry boots, which soon unmercifully blistered our feet, made unusually tender by the mud and water through which we were cornpelled to travel. Our sufferings were indescribable. Curses and threats long and loud were freely indulged in by the guard, because we could not walk even faster than their horses. Before reaching Culpepper six of our number fell by the wayside utterly exhausted. Under such circumstances it is not strange that I should think of various plans of escape during the day, but, in consequence of the 
vigilance of the guard, was mable to find the golden opportunity I sought to execute them.

Having arrived at Culpepper, we were lodged in a large public hall, where we were permitted to remain nearly twenty-four hours.

Late in the erening of the twenty-first we started on our memorable journey

\section{FROM CULPEPPER TO RICHNOND.}

Unticketed, but not unguarded, we took the cars for Rapidan Station, where we had to leave the train, as the railroad bridge was destroyed, and our party was marched to Orange Court House, a distance of six miles. Thoroughly demoralized by our thirty mile tramp of the twentieth, we found every step of this short journey pregnant with pain. The boys will not soon forget the experience of this day. The next morning we left by rail for Gordonsville, where we remained until three oclock on the morning of the twenty-third. The guards here were rery insulting and abusire, being intoxicated with bad politics and even worse whiskey. Their extremely bad conduct, cursing us and levelling their muskets at our heads, procured their relief from this duty, when their places were filled by others more human. From this place a few hour's' ride on the Virginia Central Railroad, brought us to the Rebel capital, to be consigned to the tender mercies of Libby Prison. 


\section{CHAPTEP III.}

\section{LIBBY PRISON.}

$\Delta \mathrm{T}$ eight o'clock on the morning of Friday, Octopor twenty-third, we arrived in Richmond. The streets were crowded with people whose countenances betokened anxiety concerning the result of the terrible struggle that had just terminated in Northern Virginia.

Immediately after our arrival at the depot we were hurried from the cars and marched through some of the principal streets toward the James River. As we passed along we were saluted with innumerable questions and observations, the general character of which may be inferred from the following specimens: "How are you, blue bellies?" "Why didn't you'uns all come into Richmond with your arms on?" "What did you'uns all want to come down here to run off we'uns niggers and burn we'uns houses for?" Mrs. Johnny Reb remarked: "If these are the officers of Lincoln's army, what must the privates be?" Another sensitively delicate matron, taking her cue from the latter, chimed in with a tragic shudder, "Oh, what a pity that our noble sons should be murdered by such miserable ragabonds!"

The usual southern epithets for Federal soldiers were vigorously applied, and such as the following 
were showered upon us: "Hirelings," "mudsills," "greasy mechanics," "Northern randals," etc.

A troop of boys followed in the rear, hooting, hallooing, and calling us names, and, really, as is generally the case, they surpassed the older ones for smartness and renom.

\section{FIRST IMPRESSIONS.}

After a walk of little more than a mile, we were halted in front of a large three-story brick building, old and somewhat dilapidated, situated on the corner of Twentieth and Cary streets. It is about one hunrred and thirty-fire feet long, and one hundred and five feet wide, and reminded me of the old French Bastile, with its dark and fromning walls. On the north-west corner of the building hung a large sign, which announces to the passers-by that here "Libby \& Son, Ship Chandlers and Grocers," were wont to do their business and invite their customer's. I must confess that just then I had no desire to trade with this Rebel firm for ship candles or others, though I rould have been glad enough of their provisions, but Rebel bayonets were arguments to business too porrerful to be resisted, and so we entered the famous Libby Prison.

Here we were unceremoniously introduced to Major Thomas P. Turner, the Rebel commandant of the prison, and his disciples, of whom I shall speak more at length in the following pages. And now began the work of pillaging. Every article of our clothing was carefully searched, and we were quickly dirested of everything which conld excite either the emrosity or 
avarice of a Rebel. It was easy to see that their intention was to leave us nothing which could minister either to our comfort or pleasure. But Yankee ingenuity, as was often the case, became more than a match for Rebel cupidity. Our "greenbacks"-the olject of their closest scrutiny-which some of us had been fortunate enough to save until then, had been neatly folded and safely deposited between om toes, or concealed in the lining of our garments, or solidly packed in our hollow regulation buttons, the caps of which could be easily removed and replaced; and in some instances men had their money in their mouths with a quid of tobacco, which would afterwards come out, though a little colored, yet, uninjured by the mastication. Many of our valuables also were saved by slyly passing them to those who had been previously examined, while the attention of the plunderers was intentionally diverted from us. In this way I retained my journal.

When this most disgraceful plundering was concluded, we were driven into rooms already occupied by Federal prisoners, and, on entering, were amazed at their cries of "Fresh fish," "Close up," "What army do you belong to?" "Where were you captured ?" "What's the news ?" While these questions were being asked, and answered as best we could, so great would be the press that surrounded us, that you would hear the cry, "Give them air," "Mob, disperse," etc., and, indeed, it was necessary for the crowd t) obey these orders to prevent suffocation. This excitement continued for some time after our entrance, and I afterward learned that this was a custom that 
grew out of the intense desire of the inmates to obtain the news of the outer, beautiful world, and especially of army morements, as well as from the relish of every thing that could break the dreary monotony of prison life. This was the general initiation, and the more graciously it was endured the better.

Here I had the melancholy pleasure of meeting several officers of my own regiment; glad to have their fellowship and cheer, but sad to meet them in this Hades of wo. In these long, low, gloomy and suffocating rooms, nine of which were occupied by prisoners, were incarcerated about one thousand officers, our enlisted men being confined at Belle Isle and other prisons in and about the city.

I soon found friends in this dingy abode, and began to yield myself to this new style of domestication. With the Yankee tendency to organization, we were divided into messes of about twenty each. I was assigned to "mess number twenty-one," and at once made acquainted with my new duties. Each man in turn does the cooking for the entire day. In a close, suffocating corner of the main room which had been partitioned off for a kitchen, where we were compelled to burn corn-meal for coffee, and to make rice soup and hash over smoking, broken stoves, it was any thing but agreeable to labor. The prison days were exceedingly long, and yet our turns for cooking seemed to recur with unpleasant frequency.

October 28.-I am gradually becoming accustomed to this dungeon life, and I presume I shall fall into the habit of enjoying myself at times. "How use doth breed a habit in a man!" Indeed he can accom. 
modate himself to almost any clime or any circumstance of life, a gift which no other living thing possesses in any such degree. While this process of acclimation is going on I am also gathering facts about this place and its inmates. The building, I learn, belongs to the estate of John Enders. The windows are small and carefully secured with iron bars. A strong line of sentinels is established around the building with strict orders to fire upon any man who ventures near the windows to get a glimpse of the scenery without, or breathe unvitiated air. In these filthy and unfurnished rooms we are huddled together like sheep in a slaughter-pen, awaiting the approach of monsters in human form, who are eager to destroy us by any mode of torture. Vermin of almost every kind abound, so that it is impossible to escape their loathsome presence. We have neither bunks nor chairs, and only a few have blankets, and thus, to sit or sleep, we are compelled to seek the filthy, naked floor. Of the authorities we expect and receive nothing except curses and cruelties. A short time before my arrival, a sentinel in front of one of the windows fired at a prisoner in this room, who, howerer, instantly dodged, and escaped unharmed. The ball, passing through and into the room above, selected its unconscious victim, and, without a moment's warning, launched him into eternity. All this seems to be pleasing to their chief,

\section{MAJOR TURNER,}

who, though too cowardly to meet his enemies on the battle field, revels in their misery and destruction, within the gloomy walls of a prison. 
He was formerly a student at West Point, but it is generally understood among the prisoners, that he was expelled from that institution for forgery. At the breaking out of the Rebellion, he was made captain in the Rebel service, and for his native cruelty and efticiency as a Yankee destroyer, he has recently been promoted to a majority, and assigned to this post, which is so congenial to his base desires. We come in contact with him more than with any other of the prison authorities. His character is well delineated on his countenance, where the hoof-prints of appetite hare made lasting impressions. Depravity is a terrible limner, that leaves his true colors upon the "human face divine." To one who comprehends the sublime capabilities of the human soui, there is something inconceivably terrible in their perversion.

The higher and nobler the purpose to which a life may be devoted, the darker and deeper the infamy into which it may be plunged.

There is nothing more terrible and loathsome than a human soul grown powerful in sin, and left to the horrid machinations of the evil one, and its own evil promptings. Demons, developed from germs that might have produced seraphs, become rank growths, drinking in the healthful stimulants of life and reproducing them in hideous forms of vice and crime :-

"Souls made of fire, and children of the sun,

With whom revenge is virtue."

Thus we see a soul coming pure and plastic from its Maker's hand, yet afterward standing before the world stained and hardened. Such, I conclude, is the character of the man in question. He seems to be 
free from every noble feeling or impulse, and prepared for any deed that can enlist the evil passions of our nature. He not only deprives us of little comforts which would greatly mitigate our woes, and cost him nothing, but he heaps barbarities upon us with Herculean and fiendish strength. "Seared with a hot iron" as his conscience must be, the atrocity of his conduct is so shocking as to arouse, at times, his guilty fears. He fancies that the prisoners, and even his own guards, are plotting for his life, and he has recently changed his quarters from the prisonbuilding to an office across the street.

\section{EXCHANGE RUHORS.}

November 7.-To-day there is an interval in the uneasiness of the prisoners. A flag-of-truce boat is in. It is earnestly hoped that something will be done to relieve our sufferings, but the whole matter is veiled in uncertainty. The most extravagant rumors, on exchange, are afloat among us ; and it is certainly hard to believe that they are not true. Our wishes are constantly suggesting means for their own realization. And yet it is not well to suffer ourselves to be aroused by these exciting hopes, for if once blasted they will depress our spirits, breed utter disgust of our surroundings, and have a deteriorating effect upon both mind and body. We must grow into the luxury of indifference. Stoicism, howerer reprehensible in ordinary life, is necessary here. Experience must teach is the lesson; that hard shoolmaster must lash us, until our nerves will remain unmoved eren underneath the stroke. 
But it is difficult to make room for this phi. losophy. We may often repeat, "it is not best to trust these rumors," and yet the hope rebels, and we are compelled to trust, at least, in part. We cannot control our rampant thoughts. Imagination will run wild, build some castles in the air, and dwell on distant scenes of pleasure and comfort, from which we are excluded. While fancy feasts, we are starving. The spirit is strong, but the flesh is weak, and when the spirit returns, weakened and wearied with its wanderings, how much more faint is the poor frame that takes it home.

In such struggles we engage until, exhausted, we sink into a kind of stupor, which has but little choice between life and death. There is much of the animal in this lethargy, which makes it very disagreeable to contemplate. It is natural for man to hope, and when he has outlived hope, he has outlived his manhood likewise. 


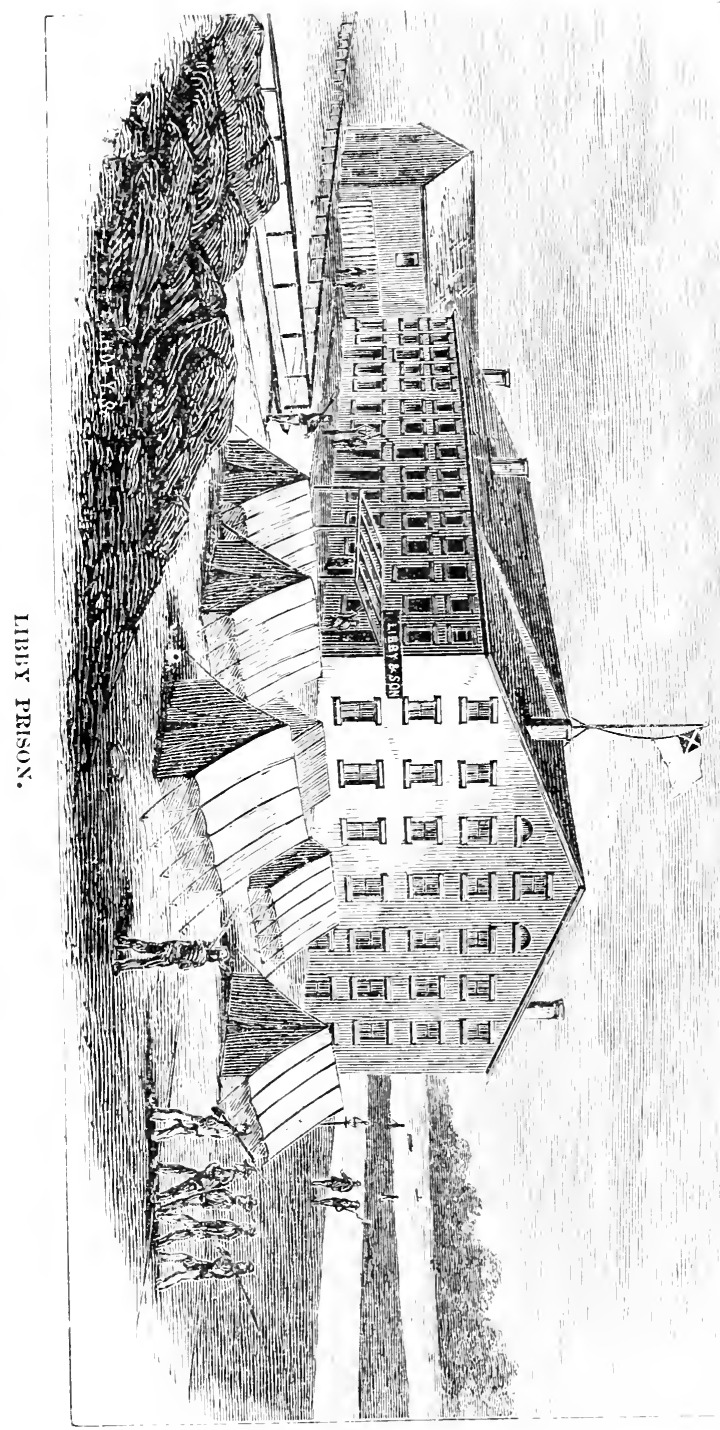





\section{CHAPTER IV.}

\section{IN THE LIBBY HOSPITAL.}

November 8.-For some days my health had been failing, and when, at sick call, the Rebel sergeant called out, "Fall in, sick!" a friend gave me the assistance of his arm, and I appeared before the prison-surgeon. With something like the businessair of a grocery-clerk, addressing a country-customer, came the rapid questions, "What do you want? Where are you sick? How long have you been so? Have you taken any medicine?" And without waiting for any answers, he turned to the sergeant with "Take this man to the hospital," and thus ended the examination.

Once in the hospital, I was soon subjected to its peculiar influence. There was the ominous stillness, broken only by a choking-cough or labored groan; the chilling dread, as though one were in the immediate presence of death and under the ban of silence; and the anxious jearning-the almost frantic yearning -which one feels in the contemplation of suffering which he is powerless to alleviate. And worse than all, soon came that hardened feeling which a familiarity with such scenes produces. 
This is nothing but an immense charnel-house! We are constantly in the midst of the dead and dying. Nearly every day, some of our comrades, and some days, several of them, are borne away, coffinless and unshrouded, to their unmarked graves. I am well aware that, in time of war, on the field of carnage, in camp where the pestilential fevers rage, or in the crowded prisons of the enemy, human life is but little valued. Yet there are moments amidst all these scenes, when the importance of life and the terror of death seem to force themselves upon the mind of every man with a power which cannot be resisted.

\section{PREVAILING DISEASES.}

Scurvy, pneumonia, chronic diarrhœa, and fever, are the most prevalent diseases. The former of these, it is well known, originates from an exclusive diet of salt rations and corn-bread. Its most effectual cure is a change to vegetable food, vinegar, or some other acid. Its first symptoms are eruptions on different parts of the body. Soon it locates-generally in the ankles. Here large sores begin to form similar to the first appearance of boils. These deepen and spread. The limbs become strollen. If not checked, it soon covers the whole body, and the flesh actually rots away and falls off the bones. It generally proves fatal by attacking the glands of the throat. These swell enormonsly, and the patient is often strangled. Sometimes it locates in the mouth; in this case the gums become softened and the teeth drop out.

How human beings can keep their unfortunate 
fellows in prison, tormented by such maladies, when they are unwilling to afford them the means of relief, must remain forever a problem in "secession ethics."

The hospital-surgeons appear to be gentlemen, and treat us with some consideration. To be sure, we are not very exacting, and consider ourselves remarkably fortunate if not subjected to positive abuse; still, much credit is due to many of the medical men of the South. They seemed disposed to make the best possible use of the means placed at their disposal, and even remonstrated with their authorities for withholding those medicines and comforts without which a hospital is not a hospital.

There were exceptions to this rule, as I learned from those who were old residents of the prison when I arrived. Some of them have been tyrannical and abusive. Our own surgeons are permitted to be among the sick, and this is a great comfort. Their prescriptions are filled, so far as the prison dispensary has a supply.

November 11.-I arose this morning very weak and weary. To sleep during the night was impossible, and much of the time was spent in coughing severely. Pneumonia is making scrious work among the sick. Many, reduced to extreme weakness by fevers, are attacked with it, and cough their lives away. The climate seems favorable for the development of pulmonary diseases, and this, aided by ou" wretched surroundings, makes havoc in our ranks. As the season advances toward winter, this disease and others prevail with greater virulence and power. 
Many prisoners, captured during the fall campaign, are sufiering terribly from their wounds.

\section{HOSPITAL RATIONS.}

Our rations, in this most humane department of Rebel-prison life, consist of one small slice of bread for breakfast, a table-spoonful of rice and a small piece of meat for dinner, and the breakfast allowance repeated for supper.

The room we occupy is next to the ground floor, and is crowded to its utmost capacity, so that many cannot get admittance, and die in their quarters in the upper rooms. We are told that there are several other crowded hospitals in the city and at Belle Isle.

After being here a week, I am still quite sick, though a little improved. Some boxes sent by our Sanitary Commission have been opened for the benefit of the sick. It was my good fortune to get some pickles with the vinegar about them. This has had the effect of checking the scurvy, with which I was much troubled, and I am in a fair way to recover.

In spite of the distressing circumstances that surround us, we yet occasionally find something to laugh at. A cheerful heart and a smiling face are better antidotes to disease than all the nostrums in the calendar; but they are more rare in southern hospitals than even medicines. He who makes us laugh is a real benefactor. It is generally considered that when a man goes to the hospital, he goes there to die. On this supposition a poor fellow, whose waggery is irrepressible, as he was brought into the hospital to-day, called out with as loud a voice as he could muster, 
"Hello, fellers, I've got leave to die, too." The sickest could scarcely repress a smile, and all felt as though they had received a tonic.

The medical fraternity has been thrown into a whirlpool of excitement over rumors of exchange. Anxiety, hope, fear, and what not, have a strange effect upon them. Some of them are well nigh insane. It was a pity to have their hopes deferred even for a few days, but at last-November twenty-fifth-their desire came, and a general feeling of joy prevails within the walls of Libby. Although many of us are destined still to remain, it is a source of consolation to know that some of our number are afforded an opportunity to regain the privileges they had lost by capture and incarceration.

\section{EXCHANGE OF SURGEONS.}

Turner issued the orders for surgeous to "fall in," early in the morning. There was a general rush among the prisoners to send some word to their friends at home by those about to be liberated. The medical gentlemen were very obliging, but had to be on their guard. They were carefally searched before leaving, and it was generally understood that should any thing contraband be discovered on or about their persons it would not only be taken from them, but the bearer be detained. Sending messages to friends on this occasion, as on all others, required some tact and perseverance. It was known that letters sent home would be read by the authorities, and as we desired to 
give our friends the first reading, we set ourselves to work to outwit our masters, which we did somewhat after our expedients of a former day. Nearly every button on the coats of those going home contained a good-sized letter written on tissue paper. The soles of their shoes and boots were loosened and papers put between them. The crowns of hats and caps were ripped apart, filled with letters, and sewed together again. Every device was resorted to that offered a prospect of success.

The chief thing desired by the prisoners was, that their friends might learn the secret of communicating with them withont the knowledge of the Rebel authorities. One wrote to bid friends to hold his letters to the fire, that the writing might become visible. Another directed a box to be sent him with greenbacks hidden in a roll of butter, or in a piece of cheese, or inside a pickle in a bottle of vinegar.

What we most expect, howerer, is that the surgeons will make such representations to the authorities at Washington as will bring about a general exchange.

I receired the Richmond Sentinel this morning from a friend up stairs, who conveyed it to me through the key-hole. This key-hole is in an unused door which has been nailed up and the lock removed, leaving this means of communication exposed, and as it has gradually grown larger from use, it is of some service to us.

\section{OLD NEWSBOY "BEN."}

Erery day a jolly old negro goes along past the 
prison crying, "Great tallyraphic news in de papers! Mighty news from de Army of Northern Virginy! Great fightin' in de Souf-west!"

It is astonishing how the cry thrills us. It has a home sound, and we forget for the moment that we are prisoners in Secessia. These papers we have, at times, been permitted to purchase at prices ranging from twenty-tive cents (two bits) to one dollar.

Here we get the southern accounts of the war, with customary embellishments. Whenever they are full of bluster, braggadocia, and abuse, we know it has been going ill with the Rebels. When the tone is mild and reasonable and conciliatory, we have reason to believe that things go on swimmingly with them. Thus we interpret their accounts, as gypsies interpret dreams.

November 26.-This is Thanksgiving day. TVe may feel-and indeed are-thankful that our condition, bad even as it is, is no worse.

Under the very worst circumstances allotted to mortals, we can still imagine something worse, and ought to be thankful. The Scotch divine, who was subject to gout and rheumatism, used to thank the Lord, when suffering with the former that it was not the latter; when the latter got hold of him, he was thankful that he had not both at once; and when both seized him at once, he was more thankful than ever that he had not the toothache at the same time.

Still, we make no very special point of being thankful. There are no chaplains with us, and no religious exercises will be held. There is no danger of its being turned into a day of feasting; for our stinted allow. 
ance will not admit of that. Major Turner allowed an issue of the remaining few of our boxes this morning, which have been in his possession for the past two months. They were all broken open, and were generally stripped of every thing which could be of any use to us. They were plundered by the common soldiers of the regiment doing guard duty here, under the eyes and with the permission of the prison authorities. Were we among barbarians, such treatment would be nothing more than we might reasonably expect. But among civilized men, who acknowledge that a God of justice rules among the nations of the earth, with the name of Christian ever on their lips, it is not endurable!

This day calls to mind some days of thanksgiving instituted by Rebels. What they had to be thankful for, nobody knows. Yet these same men, who deliberately starred and froze our unfortunate soldiers, would lift their hands to Heaven with as much ferror as a dying saint, thankful perhaps that the strength and means had been given them to torment their fellow men. Thankful that their armies were occasionally successful in their strife against the best and freest and most liberal government on earth. Thankful that the chains were tightening on the limbs of the bondman. Thankful that a fierce and cruel aristocracy were triumphing over the equal rights of the people; at least so they thought as they turned their bloodstained palms heavenward. And they thanked God for these results. A greater mistake was never made, ns we contidently believe.

If history thanks God for these seemingly retro. 
grade morements of freedom, I question whether the Rebels of the present day will join in the pæan.

November 27,-Brings us a mail from the North. I was so fortunate as to receive two letters. They were indeed like "cold water to a thirsty soul." No one can appreciate the value of a bit of paper crossed with familiar lines and home thoughts until they receive it under such circumstances. The reception of these letters, however, is an unusual occurrence; for we are seldom permitted to correspond with our friends; and then only under the most cruel restrictions. Our letters are limited to six lines of ordinary note paper, including date, signature, and address. They are carefully criticised by the Rebel authorities, and no information concerning our true condition is allowed to be sent. Every scheme that could be divined to outwit the Rebels has been resorted to, and successful to some extent; for many of the prisoners have learned the secret of writing with "invisible ink," which is nothing more than a solution of soda or saleratus. This leaves no impression on the paper until it is heated, when it becomes quite distinct, and may be easily read. But this secret was at length discovered; it occurred in this wise: A captain, writing to a fair and undoubtedly very dear friend, could not brook to be limited to only six lines, when he had so much to communicate; so, resorting to this mixture, he completely filled the sheet with " soft and winning words ;" and then, fearing lest his fair dulcinea would not discover the secret, added,-

"Now, my dear, read this over, and then bake it in the oven and read it again." 
This was too much. The Rebels thinking that if the letter would improve by baking it might be well to improre it at once, accordingly held it to the fire. This brought to light four closely-written pages of the tenderest and most heart-rending sentiment.

Since then our correspondence has been carefully scrutinized, and will doubtless in the future be subjected to all manner of tests.

\section{GENERAI NEAL DOW,}

of Maine, is the senior officer confined here. He makes no very imposing appearance; wears an old red skull-cap, which gives him the appearance of a Turk, and minds his own business. The Rebels, in particular, find him rery reticent. He seems to have a perfect contempt for traitors, and scarcely ever speaks to them. They, in turn, hate him very much worse than they do the devil. Sereral times during his imprisonment they refused to exchange on direct application from our Government.

The general has not recovered from his Maine-law proclivities by any means. He very often discourses to us from his corner on the subject of temperance, and sends home his thrusts with all his former vigor.

$\mathrm{He}$ is also something of a wit. The prison is alive with vermin, and so is the general. One day while sitting on his blanket searching his clothes, an officer said to him, "What, general! are you lonsy?" "No," said the general, "I am not, but my shirt is."

Many of his letters, written to friends in the North, with invisible ink, have been published; but his literary labors are at an end for the present at least. 
November 28.- Some of our senior officers have complained to the prison authorities in relation to our rations, but to no purpose. You might as well approach a granite rock, with expectation of receiving sympathy; for they are perfectly hardened to all feelings of humanity, and are only delighted with the intensity of our sufferings.

We are becoming accustomed to the sensations of hunger. A continual gnawing at the stomach has become chronic, and is little regarded, yet is surely having its logitimate effects on our health and constitutions.

The ravages of death are spreading most fearfully among our enlisted men on Belle Island, and in the various hospitals of the city.

The burial of the dead is a very business-like affair. As fast as men die they are carried out to the " dead house" and piled up, much as bags of corn would be, until there are enough for a load, when the keeper calls out to the prison carter, "A load of dead Yankees! Drive up your mule." The carter then drives up, and takes in his load with as much unconcern as though he was drawing wood or other articles.

\section{ESCAPE OF DEAD YANKEES.}

At first there was no such officer as "dead-house keeper," but it was noticed that for some reason the dead Yankees often came up missing-concluding either to bury themselves or to dispense altogether with such unpleasant formalities. After this the dead were under surreillance as mell as the living. 
Escaping was a regular trade. The first step was to play sick, and get into the hospital. The next was to bribe, or otherwise influence the hospital stewards, and get them to agree to do the " carrying out." The next more was to get so sick that the Rebel surgeon would say "he must die." The last perfermance of the sick man was to die in agony, and be carried to the dead house. His future movements were not very well understood, but somehow the corpse was never seen more. Ingenuity was tasked to its utmost to devise means of escape. Yankee brass was almost inrariably more than a match for all obstacles

\section{REBEL SURGEON TS. YANKEE TAILOR.}

A major, whose name I have forgotten, made his escape a short time before I entered the hospital, and deserves a medal for it. He had been a tailor before entering the service, and as the Rekels had a high opinion of Yankee handicraft, the prison surgeon sent him his coat to be remodelled after a northern pattern.

As soon as the work was neatly finished, the tailor soldier put on the surgeon's coat, and taking with him a friend as hospital steward, coolly walked out into the street, and neither of them were heard of again until they reached the Federal lines.

November 29.- More letters reached us to-day, bringing to me the sad news of the death of a sister. Oh, how inexpressibly sad do such tidings strike the heart. In the very midst of death, I am permitted to drag out a weary life, while dear ones in a land of health and plenty, are struck down by the fatal shafts. 
Her death occurred on the twentieth of October, the day after my capture. Just as I was thrust into prison and doubly bound to the grovelling discomforts of earth, she was released from the prison-house of clay, and received, I trust, into the joyous freedom of Heaven.

Our lives are all in the hands of Him "who doeth all things well." He appoints us a period of existence, and appoints a moment to depart. All other influences are subordinate to his will.

"What can preserve our lives-or what destroy? An angel's arm can't snatch us from the graveLegions of angels can't confine us there."

\section{BRAGG'S DEFEAT.}

November 30.-The Rebels are now smarting under the severe defeat of General Bragg, and although desirous of keeping us in ignorance of our success, yet we have been able to gather nearly all of the particulars. It seems that General Hooker, on the twentyfourth, succeeded in carrying, by assault, the northern slope of Lookout Mountain, while General Sherman, co-operating with him, crossed the river at the mouth of the South Chickamanga. After meeting an obstinate resistance, he at last succeeded in capturing the northern extremity of Missionary Ridge. Owing to the combined success of Hooker and Sherman, the enemy abandoned Lookout Mountain during the night, retiring toward Chickamauga. Early the next morning the battle was commenced with renewed energy by Sherman, who made an assault upon the enemy at the northern end of Miscionary Ridge. But our 
troops met with a serere repulse. The field was hotly contested with varied fortune until three o'clock in the afternoon, when General Grant, by hurling two columns against their centre, forced them back, and gained possession of the ridge. The enemy, once routed, retired rapidly toward Dalton, Ga., being hotly pressed by our forces as far as Ringold. The Rebels admit a loss of six thousand prisoners, seren thousand stand of small arms, and upwards of fifty pieces of artillery. They regard this as one of the severest defeats that they have sustained since the war began.

December 1.-The weather is extremely cold, and the sufferings of the prisoners in the upper rooms are indescribable, owing to the want of blankets and clothing. There are no fires, and, as yet, there is but little prospect of their being furnished with stoves. Many of our men on Belle Island are dying daily from exposure. Large numbers of the prisoners have no blankets, and are poorly clad. They are compelled to walk during the night-time to prevent freezing.

POSITION OF THE $\triangle$ RMIIES.

This morning we obtained the Richmond Enquirer through one of our guards. It is thought that Meade will soon come in contact with Lee. Both armies are now drawn up in line of battle, on opposite sides of Mine Run. The Rebéls seem to be greatly alarmed at the critical state of affairs, and we are most deeply interested in the result of the movement, which we earnestly hope may, in addition to the de- 
feat of Lee and the capture of Richmond, release us forever from these filthy dungeons.

I have been communicating with Lieutenant $\mathrm{S}$. H. Tresouthick, Eighteenth Pennsylvania Cavalry, through the key-hole, nearly all day, with regard to various plans of escape. My modus operandi is, to go to the head of the stairs and push a note through the key-hole when no Rebel officers are near, and it will be carried by the prisoners to the one for whorn it is intended.

\section{PLANS FOR ESCAPE.}

To give a somewhat correct idea of the plans proposed, I will give a short description of the different rooms in the prison. There are three stories besides the basement. Each floor is divided into three rooms, fifty feet by one hundred and twenty. The basement is similarly divided, and is used as a cookroom and store-house. The hospital room is on the first floor above the basement, and the room corresponding to this, on the next floor above, is the one occupied by the lieutenant. There are sinks built on the outside of the building at the same beight as each story, and running the whole length of the prison.

Tresonthick first proposed that he should feign sickness and get into the hospital, and I in the mean time should, with a saw-backed knife, cut a board out of the sink large enough to let us through.

After an investigation, it was found that our opening would let us through directly opposite the guard, whom we had no means of passing; consequently, this plan had to be given up. 
I then proposed that he should get into the hospital as before arranged, and I would manage to get a piece of rope eight or ten feet long, and then some dark, rainy night we would steal down into the basement, the outside doors of which are not locked till ten o'clock P. x., and await our opportunity.

When the sentinel's back is turned we will rush past him on either side, and with the rope trip him dows, hoping to be beyond the reach of his musket before he can fire.

This plan seems to suit the lieutenant, and we must wait for his admission to the hospital. He commenced to be slightly sick two or three days ago, he tells me.

December 3.-This morning I read the Richmond Sentinel, which was passed to me through the previously-described key-hole by friend Richardson. General Meade is reported to be retiring in the direction of Fredericksburgh. The object of the morement is not understood here.

\section{BELLE ISLAND.}

A small portion of the clothing sent on by our Government is now being issued to the enlisted men on Belle Island. Colonel J. M. Sanderson, of our service, is permitted to make the issue. The prisoners are in a state of utter destitution, and the clothing cannot be distributed without guards; the poor hoys, having been so long destitute, and having almost perished for the want of sufficient covering, now rush upon the party making the issue, and take such artirles as they need. There is no way of keeping them 
in restraint, but ly military force. There is much misery here, caused by a disregard of justice. Could all the corruption and consequent suffering be known, it would be a dark spot upon the annals of American history.

Tresouthick's illness progresses finely, and we have hopes of being able to take advantage of it soon. He has only to present himself before the surgeon a sufficient number of times, and insist that he is very sick, in order to be admitted to the hospital, as we think.

December 8.-The weather is a little more mild today, and I find my health gradually improving. The greater portion of my time is now occupied in reading "Napoleon and his Marshals." I make it a daily practice to read the Bible, and to commit a portion of St. Matthew.

There are games of amusement among us, which I sometimes participate in ; the most popular are chess, checkers, dominoes, and cards. This erening I had a game of chess with Lieutenant Carter, formerly of Baltimore.

Games of all kinds are vigorously plied to pass away time. Looking into any of the large rooms, you may see a party in one corner playing chess on a loard marked out on the floor, with chess men made of beef bones. In another corner, a group are playing checkers in the same manner, with buttons and wooden men. Others are huddled together around a et of dominoss, which they are rattling with considerable vigor.

Everywhere, and at all times, you may see the in. 
evitable greasy cards; and euchre, whist, and bluff, go the rounds in rapid succession.

Here a gronp of lawyers are holding a moot-court, with a grave judge opposite, and a panel of dulysworn jurymen sitting on the floor along the sides. Acres of valuable land have changed hands under their decisions. Horses have been adjudged to belong here and cows there, and $\operatorname{dogs}$ anywhere and everywhere. Nearly every man of the number has failed in business, and a large per cent. have been divorced; and lastly, judge and jury have unanimously decided, that they all be sent home without a moment's delay, times without number.

Debating clubs are settling important questions in different parts of the room, and youthful orators are constraining prison-life to give grace to their gestures and fluency to their tongues.

Finally, from some distant corner, may be lieard the winning words of the gospel. An old gray. haired man, it may be, is telling an attentive com pany of younger men how precious the religion of Christ is to him in the midst of his sufferings. Hymns are sung, prayers are offered, and souls are refreshed.

Many are indifferent to all these things, and are sleeping on the floor.

In this way the time is passed, and in infinitely more ways, which the ingenuity of idle men will suggest.

Getting into the hospital is no easy matter, but Tresouthick is sicker than he was, and has gord hopes. 
December 12.--Last night Captains Anderson and Skelton made their escape by bribing the grard. Skelton had been wounded, under Grant, before Vicksburg, and captured. A few days after, he made his appearance in Libby, with a patch over his eye and a green cap drawn over his head, smoking a cigar as complacently as though nothing had happened. A ball had entered his eye and come out behind his ear. Although bright as ever, he feigned dulness, and so was retained in the hospital. Anderson was just admitted, and with all the money they could muster they bribed a guard to let them ont.

This morning at roll-call two bunks were empty, but after the sergeant had gone down one tier, two men left their bunks, and went to those of Anderson and Skelton, so their absence was not observed. When the surgeon came, howerer, he missed Skelton at once, as he was "a very noticeable man." The alarm was immediately given; but, as yet, ncthing has been heard of the escaping party. 


\section{CHAPTER V.}

RETURN FROAI TIIE HOSPITAL.

Tre cumningly derised exit of Anderson and Skelton has exasperated the prison authorities terribly, and most of all because their success was due to the treachery of their own guards. A double watch is now placed over us, so that our prospect of an escape has ranished, and we must take our chances with the others in the upper rooms. It has had a decided effect on Tresouthick's "health," howerer. He is much better to-day, and will probably recover much faster than he got sick.

December 26.-There has been much excitement to-day concerning an exchange of prisoners. Captain Sawyer, of the First New Jersey Cavalry, has received a letter from Major Mulford, our Commissioner of Exchange, in which prospects of a general exchange of all the prisoners is mentioned. There are many conflicting opinions and warm discussions. It is rumored that thirty ofticers and five hundred men are already declared exchanged. There seems to be much hilarity among the prisoners; yet I fear, as has been too often the case, we shall be disappointed. True, we cannot but feel great anxiety for omr release; yet such reports have been so ofter in circulation that I can 

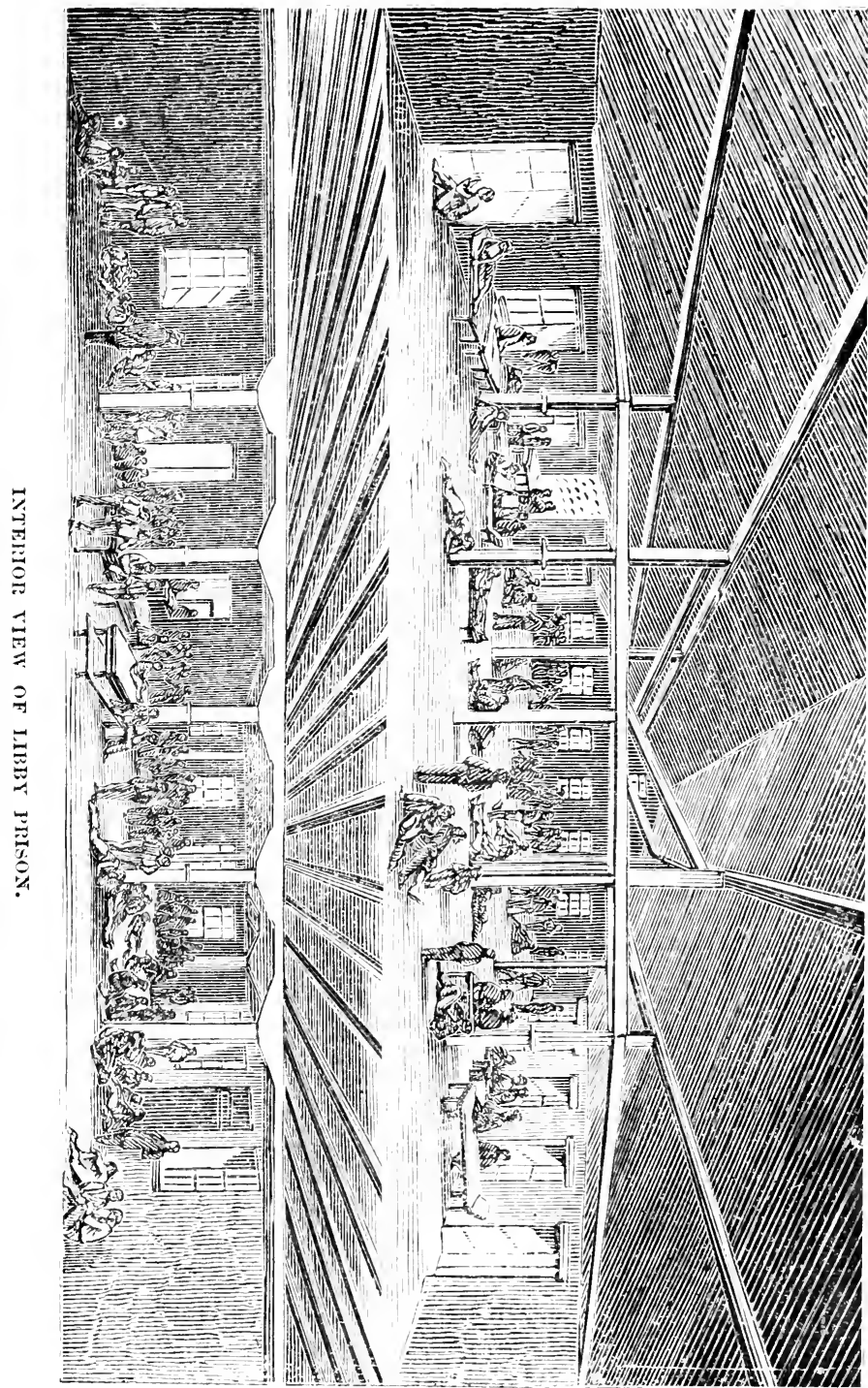

place but little confidence in anything that may be said in relation to this subject.

Sawyer has become our best authority on exchange, and expresses his opinions with all the bombast and assurance of a Wall-street broker. This is the Captain Sawyer, who, with Captain Flynn, of the Fiftyfirst Indiana Infantry, was sentenced to be shot in retaliation for two Rebel officers tried and shot by Burnside, in Kentucky, for recruiting within the Federal lines.

Flynn was a modest man, and bore his notoriety commendably. Sawyer did a great deal of talking, and made himself a mark for many rich jokes. The prisoners often remarked that they would give a thousand dollars to be shot as Sawyer was.

\section{HOSTAGES DESTINED FOR SALISBURY.}

A short time since twenty-four captains were ordered down to Turner's office to draw lots for the chances of going to Salisbury, North Carolina. Three of the number were to be chosen as hostages for as many Rebel officers confined by our authorities in the penitentiary at Alton, Illinois. The lots fell on Captains Julius L. Litchfield, of the Fourth Maine Infantry, Edward E. Chase, First Rhode Island Cavalry, and Charles Kendall, of the Signal Corps. Last night they were ordered out and sent to their destination, where they are sentenced to hard labor.*

December 31, 1863.-This day closes up the old year, and soon, if life be spared, we shall enter upon

* We afterwards learned that they refused to work, and were never compelled to. 
the duties of the new; and how shrouded in gloom are the issues of coming time. Thronging memories of past joys are throwing a pall of sadness on the countenances of many, while others, thinking of the festivities of other days, on the occasion of this anniversary, seem desirous of celebrating as they were wont to do in the more peaceful days of yore. Many are making preparations to have a dance in the "cookroom" this erening. Erening advances, and with its onward march the dance ensues. For a time they seem to forget that they are securely enclosed within these inhospitable prison walls. The merriment and hilarity continue till the old year passes away to return no more.

Some, apparently disgusted with the reckless merriment, collect in groups, and sing, in full chorus, national songs, till the old year is gone. "The StarSpangled Banner," "Red, White, and Blue," "Rally Round the Flag, Boys," peal through the long rooms with terrible emphasis, and, when the chorus,-

'The Union forever,-hrrrah, boys, hurrah !

Down with the traitors and up with the stars,

While we rally round the Flag, boys, rally once again!

Shouting the battle-cry of Freedom!"

is reiterated again and again, with significant beating of feet, it seems as if the rery roof must give way before the accumulated rolume of sound.

Some, as quietly as they can, in the midst of so much noise, watch the old year out, according to their custom, with prayer and religious songs. All make a "watch-night" of it, for sleep is entirely out of the question 
Some time ago a contribution of a little money, still preserved from the rapacity of the authorities, was taken up among us, and some musical instruments were purchased. A bass-viol, violin, and banjo, compose our orchestral display, besides a bushel or more of "bones."

All these are on "extra duty" to-night and certainly assist us, in some degree, to forget our aches and privations. Such jollifications the Rebels allow, I suppose, because they happen to be in good humor or have amusements of their own to attend to.

\section{NEW YEAR IN LIBBY.}

January 1, 1S64.-We hail the new year with peculiar emotions, hoping it may be the harbinger of release, and that its experiences may be less dark and repulsive than those of the past. Its records will, ere long, be fixed by the historian, and posterity will know the successes and defeats, the trials and sufferings, of the present erentful epoch.

Some little attempt has been made by the cooks to give us a "New Year's dinner," although no extra rations have been issued. For instance, instead of simply boiled rice and corn-cakes, they hare given us rice soup, or rice-water and gruel; rice pudding, that is, boiled rice mixed with corn-meal and water; cornmeal pudding, which is meal-batter mixed with boiled rice; then we have had boiled rice and corn-bread, pure, unmixed, à la Libby. It has been well nigh equal to the fare described by the poet of Castle Thun der. He says :- 
"We hare eighteen kinds of food, though 'twill stagger your belief,

We have bread, beef, and soup, and bread, soup, and vecf;

Then we separate about, with twenty in a group,

And get beef, soup, and bread, and beef, bread, and soup;

For our dessert we obtain, though it costs us nary red,

Soup, bread, and beef, and beef, soup, and bread."

The following is now our daily allowance of rations:-Three-fourths of a pound of coarse cornbread, one gill of rice, one-half pound of beef, and a very little salt. On such rations we are left to live or die. Groceries can be purchased of the prison commissary at the following rates:-

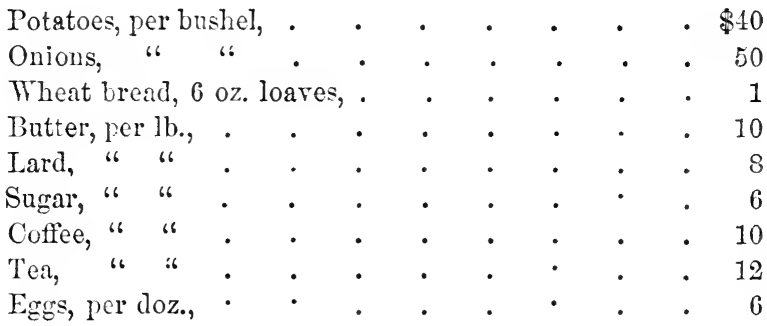

At the above prices the prisoners may purchase the necessaries of life by disposing of their clothing, rings, and anything else of value which it may be their good fortune to possess.

PUNISHMENT FOR SINGING NATIONAL SONGS.

January 24. - It has all along been our custom to go down to the cook-room occasionally for a prome. nade, there being better opportunities for exercise there than in our own quarters. It is a great relief to walk without being constantly compelled to elbow 
your way through a crowd, or to be cautious lest you step on some sick or weary sleeper stretched along the floor. Accordingly, I went down last evening for a walk, and there found about sixty comrades marching around the room at double-quick, in column of fours. I fell in with them, and all commenced singing "StarSpangled Banner," "Rally Round the Flag, Boys," etc.

This had continued for some time, when the door leading into the street suddenly opened, and a squad of armed Rebels filed in. Turner was at their head, and quickly crossing the room and placing himself at the door leading up stairs to prevent any of us from making an escape, he began, "Now, then, you $\mathrm{d}$ - d boisterous scoundrels, I'll teach you to begin your cursed howling in this building again. I want you to understand that you mus'n't drive people crazy out in the streets with your villainous Yankee songs." Then, turning to the guards - "Take your stations about these $d-d$ rascals, and shoot the first man that dares to stir out of his tracks, and relieve each other till further orders." To us again: "Now, $d-n$ you, you will stand here till twelve o'clock to-night; and make a bit of noise or move from your places, at your peril." He then ordered us into line, and marched us to the north end of the room, where we were kept till the appointed time.

The fires went out early in the evening, and the sold became intense. Some managed to get blankets from their friends abore, but the guards soon put a stop to such transactions. One man from above called cown to a friend, through a knot-hole in the floor, 
and asked him if he wanted a blanket. The guard heard him, cocked his gun and aimed at the hole; but a call from below gare the man warning, and he fled. So much for singing national songs. But patriotism will find vent somehow, in spite of Rebel vengeance.

The Jews, during their captivity, hung their harps on the willows, and sighed bitterly when they were asked to sing the songs of Zion. Union prisoners seem to be affected very differently.

January 25.-John Morgan, the famous Rebel raider and guerrilla, visited the prison to-day. His popularity is very great just at present, owing to his escape from a northern prison. Turner and a large company of pompous Confederates, accompanied him through the rooms.

As they approached the end of the room occupied by General Dow, they naturally expected him to recognize them, or otherwise show some signs of life; but the stern old general did not for a moment raise his eyes from the book he was reading, until the last Rebel had passed, when he gave one contemptuous glance at them, and continued lis reading.

Morgan is a large, fine-looking officer; wears a full beard, and a Rebel uniform, trimmed with the usual amount of gold braid.

"THE GREAT YANKEe TUNNEI."

February 10.-I am making notes of the most exciting events which hare occurred since my captiv. ity. I am often interrupted by Turner and his minions, who are almost frantic over the mysterious dis- 
appearance of one hundred and fifteen of our felluwsufferers from the prison last night. These Rebels are running up and down tarough the rooms to learn, if possible, the secret of this grand escapade. Here it is on paper: Early in the winter, Colonel Thomas E. Rose, Seventy-seventh ]? ennsylvania Volunteers, conceived a plan of escape, and organized a secret company of twenty-seven, who were to dig their way to freedom. None were admitted to the secret but the workmen.

Colonel Rose was well calculated to superintend the work, for he had served in the Mexican war, was taken prisoner by the Mexicans, and after a short confinement, escaped, by tunneling from the prison a sufficient distance to be (3lear from the guards. He had served his apprenticeship, and was now prepared to manage and direct.

After thorough orgarization of our company, with secrecy well enjoined, we adopted the following

\section{PLAN OF OPERATION.}

In the basement of the building just below our cook-room was a small unoccupied room, which had been closed since our arrival, and was never entered. From this room or cellar rose a large chimney, which passed through the cook-room, and so to the top of the building. Our first work was to make a hole in the chimney from the kitchen, which opening we could easily conceal by means of some slop-barrels. These barrels we managed to empty ourselves, so that all danger of detection from this point was carefully avoided. A short ladder, which the Rebels had brought into the rooms for the purpose of raising their 
miserable flag on the building, was used to make our descent into the dark room below. Inquiry was made for the ladder, but as no one seemed to know anything about it, it was inferred that it had been converted into fuel.

At the foot of the ladder another opening was made through the chimney wall leading into the underground basement-room. By removing a few stones from the wall of this room, we were in a situation to commence the work of tunneling.

\section{IMPLEMENTS USED IN TUNNELING.}

The only implements in our possession for performing the work, were an old trowel and half of a canteen. The arduous labor was commenced with only the fragment of a canteen, but with this, the progress was so slow, that the most patient were almost disheartened. Fortunately for us, a mason came in to repair the prison walls, and, going to dinner before he had finished his work, left his trowel, which in his absence most mysteriously disappeared. To him it may have been of but little account, to us it was a God-send. With the aid of this implement, we were able to make more rapid progress, were greatly encouraged, and worked night and day with ceaseless energy. Two of our number were kept in the tunnel almost constantly. One, by a vigorous use of the trowel and canteen, would advance slowly on, placing the loosened earth in an old blanket, which the other would convey out of the tunnel into a corner of the room whence the tunnel started.

Our course was due east, under the street where 
constantly paced the sentinels, who at every hour of the night, were wont to cry, "Post No. 1, all's well!" "Post No. 2, all's well!" etc. Little did they dream that Yankee ingenuity and perseverance were per. forating the solid earth under their feet, and opening a path to freedom.

As we progressed in our work we experienced great difficulty for the want of pure air to breathe, and to sustain our candles, which refused to burn. Consequently one of our party was compelled to stand at the opening, fanning air into the tunnel with his hat. Our atmospheric difficulties were the more increased by the small size of the hole, which was a little less than two feet in diameter, quite irregular in consequence of large stones, and descended in a line below the horizontal. This severe labor was carried on, without much interruption, for more than three weeks, when, at last, the plan came near being a failure, by a sad mistake in our measurement. Our intent was to reach the yard of an old shed or warehouse, in which were then stored the boxes sent us by the Christian and Sanitary Commissions, and by our friends at the North.

Thinking we had reached the desired point, an opening was made to the surface, when we found we were still in the street, outside the fence, and within a few yards of the sentries. Not discovered by this mishap, the hole was quickly filled with a pair of old pants and straw, and the work of excaration continued to the place intended. The selection of this point was very fortunate, as the Rebel guards used to skulk about this building at night, for the purpose of 
plundering the boxes; and on the night of the escape, the sentinels about the prison saw every man who came out, but supposing they were Rebels, only whispered to each other, "The fellows are going through the Yankee boxes mighty fast to-night." These whisperings were distinctly heard by some of our men.

The tunnel was about sixty-five feet in length, and was ready for the exit early last evening, February ninth.

\section{THE SECRET DISCLOSED.}

The company of diggers had entered into an arrangement that they should make their exit first, and inform the others just as they were going out; but each man had a particular friend whom he wished to notify, and, as we were seen packing onr clothing, it soon became suspected that something unusual was in the wind. Curiosity, once on the alert, soon discovered the secret, and then all were jubilant with the hope of escape, and commenced packing up. But egress was so slow that it soon became evident to the cool calculator, that at the best but a comparatively small proportion of our number would be fortunate enough to take their departure from Libby, before daylight would forbid any further efforts to breathe the free air of heaven.

\section{STRIPPING FOR THE CHIMNEY.}

In order to get down the chimney, as well as along the tunnel, it was necessary to strip naked, wrap our clothing into a bundle, and push this on before us. As soon as it was seen that only a few could possibly get out. many, and in fact most, became self. 
ish, and thought only of furthering their own wishes, al: rushed for the mouth of the tunnel, each man seeming determined to be first out. By this movement, the organization formed by the working party was broken up, and the workmen, who were to have had the first opportunity for escape, were not more favorably situated than those who never had borne a hand is the digging. At the mouth of the tunnel were hundreds eagerly waiting their turn. Through the intense anxiety, there was a rush and a crowd, each one being eager to improve the opportunity. Muscle was the "trump-card," and won all the victories. The weak had to step aside, or rather, they were pushed aside without apology. No respect was shown to rank or name. A long-armed second-lieutenant had no hesitancy in taking hold of a pair of shoulders that wore eagles and pushing them out of the way. There was no standing aside for betters. No deference was paid to age, and unfortunate gray hairs ceased to be honored. Mere physical force was the test of championship. Those poor, weak ones, who got help to gravitate to the outskirts of such an eager, crowding mass, just as surely as the light kernels will find their way to the top of a shaken measure of wheat, thought, as they felt themselves being crowded farther and farther from the opening:-

"Oh, it is excellent

To hare a giant's strength, but it is tyrannous

To use it like a giant!"

I made several efforts to assert what I supposed to be my rights, but, as I had not at that time much muscle to back my claims, they were not recognized, and 
thus I spent the whole night without arail in this bootless struggle for freedom.

In digging the tunnel we had encountered a large roct which we could not well remore, and the passage at this point was very narrow. Lieutenant Wallace $\mathrm{F}$. Randolph, Fifth United States Artillery, a corpulent fellow, was caught fast by the root. There was a man before him and another behind him, who almost entirely excluded atmospheric circulation, and before they could pull and push him out of his unfortunate situation, he was nearly dead. He, howerer, succeeded at last. This blockade greatly retarded the line of march, and made the crowd within still more desperate.

\section{THE STAMPEDE.}

Some of the outsiders in the struggle, who despaired of accomplishing anything by strength, had recourse to stratagem. There had been considerable noise during this contest for freedom, and the guards were expected to make their appearance at any moment. The outsiders, taking advantage of this apprehension, went to the farther end of the cook-room and in the darkness made a racket with the pots and kettles, which sounded very much like the clashing of fire-arms; while some of their number in the crowd sang out, "Guards! guards!"

In an instant every man was gone from the tunnel, and there was a frantic rush for the single stairway, by about five hundred men. Such a struggling and pressing I have never elsewhere seen or participater 
in. We neither walked up nor ran up, but were literally lifted from our feet, and pushed along in a mass up the passage, and made our entrance through the door at the head of the stairs as though we had been shot from a cannon, the most of us not stopping until we struck the wall on the opposite side of the room. While this was going on, the scamps who had given the alarm were quietly passing out of the tunnel.

The ruse was soon discovered, however, and in a few minutes there was as great a jam at the mouth of the tunnel as ever. But so eager and unthinking were we, that within half an hour the same dodge was played on us again by others, and there was another stampede up the stairs.

It is a wonder that this business was not interrupted by the guards, who did not at all suspect what was going on. This was probably owing to the fact that great noises in the cook-room were the general experience of our nights as well as days. It is, however, reported that one sentry was heard to call out jocosely to a companion on the nearest beat, "Halloo, Bill,--there's somebody's coffee-pot upset, sure!"

This struggle continued till morning, when the opening in the chimney was covered, and we went to our quarters. Here a "count" was made, to discover how many had made their escape, when it was found that one hundred and fifteen were missing. Arrangements were at once made to account for their absence, and certain men were designated to cross the room slyly during roll-call and be counted twice.

For some reason the authorities were late that 
morning, and did not make their appearance till about ten o'clock. In calling the roll the men attempted to cross the room, but were discovered, and so the count came one hundred and fifteen short. The clerk thought tinere must be a mistake, and so counted again, but with the same result. The authorities also thought there must be some mistake, and joked little Ross, the prison clerk, who was none of the brightest, because be could not count a thousand Yankees. This time we were marched from one room to another, and counted one by one, but in every way there were one hundred and fifteen men missing. We of course were as inuch surprised as the Rebels. They next sent for Turner, and he counted us two or three times, but with equally unsatisfactory results. He asked us where they had gone and how they got out, but not a man knew.

The escape was at once made public, and the papers were filled with it, and the most effectual means were used to secure their recapture.

\section{THE GUARD IN CASTLE THUNDER.}

The authorities were terribly exasperated, and at first arrested the guards and threw them into Castle Thunder, thinking, as a matter of course, that they had been bribed. This set the fellows to thinking, and one of them recollected that he had seen a great number of men in the lot near the Yankee boxes. Latouche, the prison adjutant, hearing of this just before night, went and found the opening. Next, they questioned the prisoners as to where in the build- 
ing it began, but could get no satisfaction; and not antil after a long search, did they find the opening in the chimney.

They were really pleased with the shrewdness of the scheme, and were loud in their praises of Yankee ingenuity. Guards were placed over each end of the tunnel, and it was on exhibition for a while. Crowds have been to see the "Great Yankee Wonder," as they call it.

RECAPTURE OF THE ESCAPED.

February 12.-Twelve of the escaped prisoners were brought in to-day, and thrown into the cells. Poor fellows! they look crest-fallen enough.

February 13.-Sixteen more of the escaped prisoners were brought in this morning and placed in close confinement. Their rations have been greatly reduced, and many of them have been put in irons.

Turner allowed an issue of boxes to-day, which have been in his hands for the past two months. The scoundrel had given our Government the assurance that all private boxes sent on to the prisoners would be immediately distributed; but in this case there is not even "honor among thieres." Most of the boxes were plundered under the eyes of the prison authorities; and those that were issued were robbed of their most valuable contents. These are doubtless the boxes the guards saw their comrades robbing on the night of the escape.

Twenty more of the escaped prisoner's have been brought in during the day, making in all fortv-eight. March 8.- Some of the guard, more communica. $4^{*}$ 
tive than discreet, have been led to disclose all they know concerning Kilpatrick's raid. It seems, from what we can learn, that an expedition has been organized for the purpose of releasing the prisoner's at Richmond. We have heard the dull booming of artillery at intervals during the day, which proves that our troops are already engaging the enemy in the fortifications. The prisoners are all on the qui vive, anxiously awaiting the result; and how anxiously. When, since the commencement of the war, has there been so much at stake? Richmond to be gained or lost, and with it the freedom of thousands of brave men, incarcerated in filthy dungeons, and dying of starvation!

To be ready for an emergency, we have organized ourselres into regiments, appointed officers, and made all necessary preparations for co-operating with our troops in case of a release, as they will undoubtedly be prepared to supply us with arms. If we are suffered to remain here, we hope, in a measure at least, to aid in the rescue.

\section{HOPES AND FEARS.}

The day wears away, and still no change in the situation that we can learn. Night comes, and the welcome sound of artillery has ceased, and the prisoner's are earnestly asking, "Is it a repulse, or has darkness put an end to a conflict destined to break forth with renewed energy in the morning?" The Rebels seem as much in doubt as ourselres, and equally desirous of information. It is a comfort to hear the opinions of others under the circumstances, whether we accept those opinions or not. 
March 12.-During the last few days we have learned some of the particulars from Rebel sources, concerning the fate of Kilpatrick's expedition.

It appears that at Frederick's Hall, Colonel Dahlgren, with about five hundred men, was detached, with orders to move by the way of Louisa Court House, while Kilpatrick, with the main body, moved on Ashland, thus threatening Richmond with two columns, destroying all government property on their line of march. But a misfortune, which a military commander in an enemy's country is so liable to meet with, thwarted one of the best conceived and most daring plans of the war.

\section{DEATH OF COLONEL DAHLGREN.}

Dahlgren had employed a negro, as guide, who betrayed him by leading the column in the direction of Goochland. When Dahlgren discovered his mistake, he ordered the negro to be executed for his perfidy, and, changing his course, commenced marching rapidly upon Richmond; but the Rebels were now well informed of the movement, and were on the alert.

On his return from the city, Dahlgren destroyed the Dover flouring mills and several private flouring establishments. He also materially injured the James River Canal; but in attempting to cross the river he was surprised by a large force of the enemy in ambush, who fired upon him, killing him and scattering his command.

Kilpatrick, deprived of the valuable services of Dahlgren, and having also to contend against an enemy who were receiving large reinforcements from Pick. 
ett's brigade at Bottom Bridge, acted the wise part, and retired during the night in the direction of Mechanicsville.

The advantages gained from the expedition seem to consist wholly in the large destruction of Rebel property, and also in cutting the communication between Lee's army and Richmond. The enemy captured a few prisoners, and, of course, claimed a decided victory.

\section{REBEL BARBARITY.}

The prisoners captured from the raiding party are treated with the greatest inhumanity. The Rebels evidently have not exhausted all their resources of cruelty yet; for we are well treated in comparison. Officers, enlisted men, and negroes, are crowded together in filthy cells, and not allowed to communicate with the other prisoners. Their rations are much less than ours, and even of a poorer quality; no indignity so great as not to be offered them. A Rebel sergeant brings their meals to them, and then orders them to sit down alternately with the negroes. Many men have done this by chance, or from choice it may be, and thought nothing of it - but to be compelled to sit in such a manner by Rebel orders, for the purpose of affording amusement to idle lookers-on, is something more than an American's pride can endure with equanimity.

They are not allowed to leave the room, and instead of going to the sink, are compelled to use an open tub which stands in one corner of the room. The object seems to be to impose a sense of disgrace on the men, and subject them to the ridicule of their 


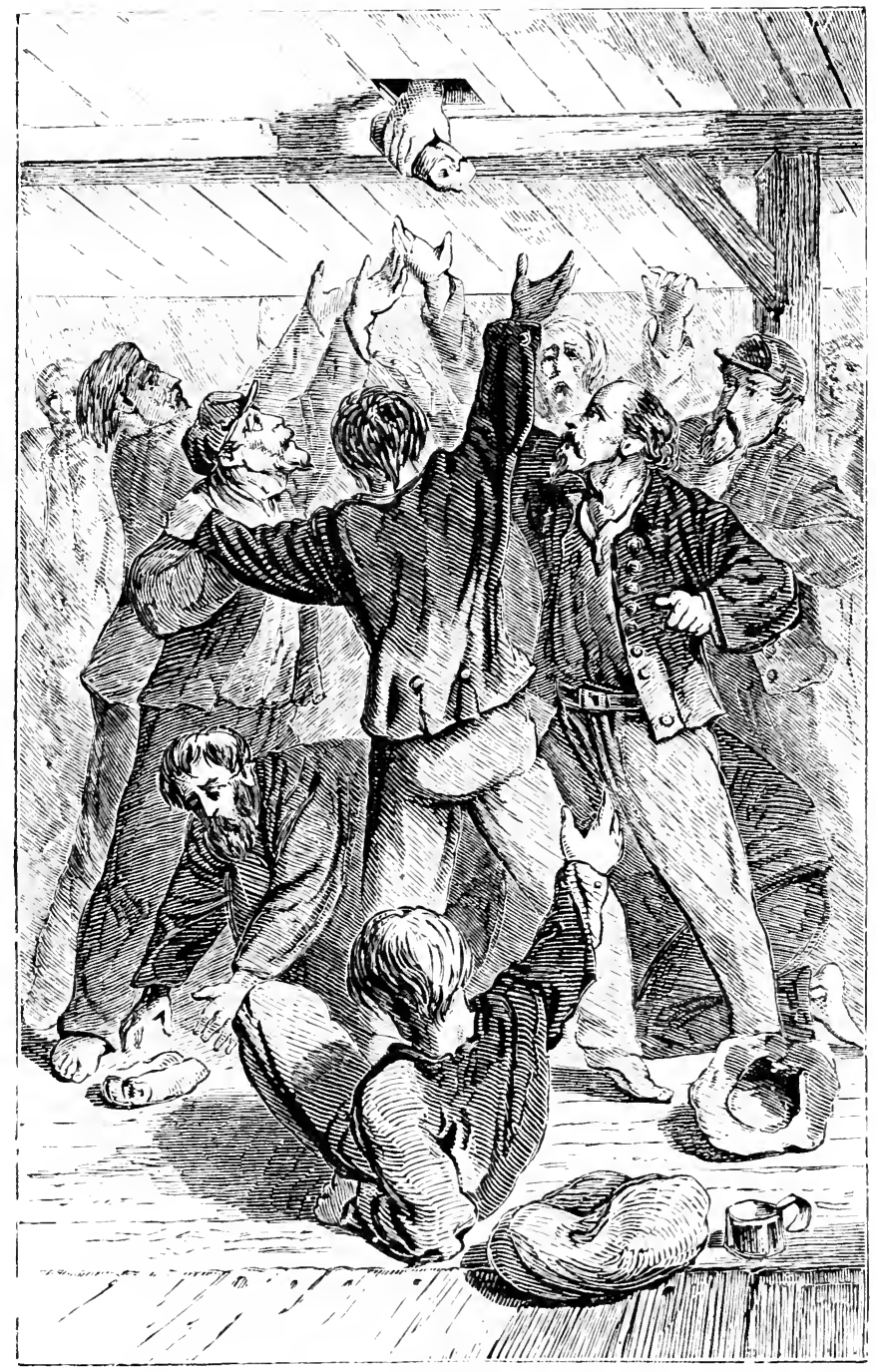

TIIE HOIE IN TIE FIOOF. 

own comrades, if possible, as well as to that of the Rebels.

The reason they assign for this inhuman and uncivilized system of torture, is the destruction of public and private property during the raid, for which they hold them responsible.

\section{THE HOLE IN THE FLOOR.}

The cell in which the raiders are confined is $\mathrm{di}$. rectly underneath my room; of course, every device is used to open communication with them, that we may get a true history of their treatment, and also for the purpose of alleviating their sufferings as much as lies within our power. We have succeeded, by the aid of a saw-backed knife, in cutting a small hole through the floor, which we have kept carefully concealed.

The authorities are in the habit of inspecting the floors continually to see that nothing is wrong. The bole opens through the ceiling of the cell, just over a large beam only a few inches below it. This prevents their seeing it from below, while the raiders, by climbing upon a table, can place a tin plate on the beam, and receive whatever is put down to them. To avoid their seeing it from our room, we insert the piece that was sawed out, and plaster it over well with the vile black soap issued to us.

Through this hole we have furnished them with a share of such rations as have been issued to us. Sume of our number were discovered by the Rebels while communicating with them, and, as a punishment for this offence, have been transferred to their cell. 
Henceforth, this was made the penalty for any such attempt; but its only effect was to warn us to be more cautions in the future.

\section{THE PRISON UNDERMINED.}

March 15.- Immediately after Kilpatrick's raia, the prison authorities set to work to undermine the building. The small room from which the tunnel commenced, has been filled with a large quantity of powder, and now "the Yanks are prepared for $\mathrm{h}-1$," as they graphically express it. This is said to be in the erent of our attempting to escape, or of a release being attempted by raiding parties. The whole transaction is in perfect harmony with their ideas of cirilized warfare.

Such a plan for wholesale murder evinces a state of depravity on the part of the authorities at Richmond, to which we challenge the historian to find a paraliel in the records of any civilized nation. Can such a people, who will perform acts of this description without apparent shame or conscious self-abasement, be entitled to be called by the mild term "enemies"? None but the blackest of traitors could resort to such an expedient.

Train have been laid from this room to various guard-posts, where they can be fired at a moment's notice. Turner himself has given us to understand that if any more attempts are made for our rescue, the prison will be blown to atoms.

March 20.- Sixty of our number were paroled to-dry, and taken to City Point for the Confederate officers brought down by the Federal authorities; 
they are to be exchanged; Major McIrvin, of the old regiment, is one of the fortunates. The prisoners are in excellent spirits, and are universally afflicted with "exchange on the brain." Three boat loads have now been permitted to return to "God's country," including many of our enlisted men from Belle Isle.

\section{BELLE BOYD.}

A few days ago, the famous Belle Boyd, a Rebel spy, who was at one time captured by Kilpatrick and sent on to Washington, came through the prison. We received no warning of her approach, and were employed, as usual, looking for live stitches in the seams of our clothing. Some were sitting on the floor, with their shirts off; others were giving their last pair of pantaloons a careful scrutiny, while others had dispensed with both these articles, and were performing ablutions at the bath trough. She bore herself with becoming dignity, however, and seemed to look on all, "in the calm light of mild philosophy."

March 22.-The officers captured during Kilpatrick's raid are still confined in the cell with negroes and the officers of colored trcops, who have always been treated as felons.

I came very near being detected this morning by Sergeant Briggs, while attempting to administer to their wants through the previously-described hole in the floor. I had stationed pickets about the building to warn me of the approach of the authorities, but the sergeant happened to be in the small room nccupied by General Scammon, at the time I opened 
the hole, and hence was not seen by the men on the alert for him. Upon leaving the general's room, the sergeant passed within six feet of the place where I was so busily engaged in putting down corn-bread and burnt-meal coffee, that I did not notice his approach. Several prisoners, however, who were watching, stepped between us, and thus fortunately saved me from sharing the fate of those whose sufferings I was endeavoring to alleviate.

\section{PRISONERS FROM PLYMOUTH.}

April 25.-Our number has been increased today by the arrical of several "fresh-fish," captured recently at Plymouth, North Carolina. Having been in comfortable quarters at that point ever since their enlistment, they feel the privations and hardships of prison-life much more than prisoners in general. Long, fatiguing marches, and the hardships of many campaigns had somewhat prepared the most of us for still greater endurance; and then we have discovered many expedients for getting along, which only a long experience can make available.

It was quite amusing to see how the "Pilgrims" regarded their "position." Having prepared their first rations in Libby, which, however poor they might be, their long march had made acceptable to them, they remarked that there was no suitable place for taking their meals, and were not a little embarrassed at the merriment the remark produced among the old prisoners, who had long since ceased to consider where they should eat, but what? The absence of bunks, and chairs, too, gave them equal 
solicitude. They are trim-looking fellows, and wher we look at our own tattered garments and haggard faces, it seems a pity that they must be reduced to a similar condition.

Through the new arrivals, we are enabled to learn some news from our armies, and the particulars of the fight in which they were captured. It appears that they were overpowered at Plymouth, and, after repelling several desperate charges, were compelled to surrender. Brigadier-General W. H. Wessels was in command of the post, and was among the captured. The general is an old man and looks worn. The Rebels give him credit for desperate courage at $\mathrm{Ply}$ mouth. He made no surrender, but was actually overpowered behind the intrenchments, by an overwhelming force.

April 26.-The weather is very cold and disagreeable. No fuel is allowed in the upper rooms. Our suffering is intense. Our men on Belle Isle are being removed to Georgia. Consequently exchange stock is declining rapidly.

\section{TIIE GOERILLA, MOSBY,}

passed through the prison to-day. $\mathrm{He}$ is about twenty-eight years of age ; has a slight figure, light, straight hair, and a smooth face, except the upper lip, which is hidden by a faded German moustache. He recognized many officers whom he himself had captured, and pleasantly remarked that he was glad to see them here. Very little attention was shown him, as we regard it a disgrace for any man to ac. sompany a Rebel through the building. 
April 28.-Exchange stock is up again. Wall. street is no comparison to Libby for variability of stocks. It is rumored that a boat, laden with prisoners from the North, is in, that terms for a general exchange are agreed upon, and that Aiken's Landing is to be the port of transfer.

Aprit 30.-Despondency is written upon all faces to-day. Our hopes of exchange are all blasted. The feelings occasioned by our disappointment can be better imagined than described, but imagination, even in her most extravagant flights, can but poorly picture the horrors of this prison life. Our constant experience is "hope deferred," and yet, "the miserable have no other medicine, but only hope!" and we must continue to hope on.

Many are endeavoring to break the tedium of their miserable condition, by cutting bones into all kinds of trinkets, crosses, rings, boxes, pins, etc., in which they display no little amount of ingenuity and persererance. Their only implements are old jack-knives and tableknives hacked into saws, the Rebels having removed from us, since the discovery of the tunnel, all tools by which filing, sawing, digging, or cutting, could be done to any advantage. Others are studying or reading books, which were bought at the Methodist Book House in the city for us, and also sent from the North. While others still do little else than walk about the rooms, muffled up in their gray blankets, pounding their hands and fect to keep then warm, and chatting with their friends about exchange. As a general thing, time with us all moves only on lead- 
en wings, and we look with anxiety for warmer, pleasanter weather.

May 6.-There is great excitement in the city today concerning war matters. The campaign seems to have fairly opened in the Wilderness, and so far as we can learn, the "boys in blue" are everywhere victorious under their new and popular leader, General Grant.

Lee is reported to have been defeated, and to be falling back to the fortifications. Several regiments passed through town this afternoon, on their way to the front. It is evident that there must be some truth in the rumor, for at eleven o'clock P. Mr. we were notified by Turner to be ready to leave the prison at a moment's notice.

At twelve o'clock the adjutant's clerk, Mr. Ross, began calling the roll. As his name was called each prisoner passed from the cook-room, through the door opening on Cary street, and filed down between two lines of guards, closing up to those who had preceded him, and receiving, as he took his place in the ranks, a "corn dodger," which we were told must satisfy hunger until another issue could be made. I conld not help rejoicing at my exit from the walls of Libby, for I felt that our condition could be made no worse, while a change of base might present opportunities for escape. This is the circle around which most of my thoughts revolve. I am not becoming satisfied with imprisonment, any more than to try to make the best of my surroundings, but I chafe under these restraints; my curbed spirit longs 
to be free, and whatever may tend to bring me to that goal I accept with delight.

FAREWELL TO LIBBY.

A few of the prisoners were inclined to be despondent, and seemed to indorse the old maxim of "better bear those ills we have, than fly to others that we know not of." But I cheerfully accepted the change even for the sake of change, and with the hope of better days.

We did not leave Cary street until the dawn of day, when we moved up to the first bridge and crossed over the James to Manchester, where we were packed into cattle-cars, and started for the South. Our place of destination was not known, but was supposed to bo some point in Georgia. 


\section{CHAPTER VI.}

\section{IMPRISONMENT AT DANVIILLE, VIRGINIA.}

Just at daybreak on the morning of May serenth, our train, heavily laden with its human freight, moved slowly away from the Rebel Capital, in the direction of Danville, which we reached about ten o'clock in the evening. Our ride was long, tedious, and full of plans of escape, with a few daring exploits. Being badly crowded in filthy, rough box-cars our trip was anything but pleasant. Just before reaching our destination, several of our number effected an escape from the cars; the night having set in facilitated their projects.

Lieutenant G. R. Barse, Fifth Michigan Cavalry, an old and intimate prison friend, jumped from the train while in motion. Twenty shots or more were fired at him by the guard, and he dropped to the ground. The Rebels boasted that "the d-d Yank would never escape again," and were so well satisfied of it that they did not think it worth while to stop the train. We afterwards learned that he got off with a slight flesh wound, but was subsequently recaptured and brought back to prison.

Nearly every expedient for release was resorted to, and several attempts were crowned with success. By the aid of saw-backed knives, holes were made or 
hacked in the sides of the cars, through which sereral made good their escape, in some instances unnoticed by the guards.

The party with whom I was confined were en. gaged for some time in this way, but just before our work was completed, our plan was discovered and frustrated by the vigilance of our keepers. We were not, however, easily discouraged, and as soon as one plan failed it seemed as though thousands of others were conceived, and so we were almost constantly at work with

\section{NEW PLANS OF ESCAPE.}

What will not a man do to escape from an imprisonment, which is so loathsome as to be in many respects eren worse than death, with the hope of reaching a personal freedom, for which all living things yearn and struggle? How often we felt the power of the Spanish song, whose first lines have so many times thrilled the Castilian heart:-

"O, libertad preciosa,*

No comparada al oro,

$\mathrm{Ni}$ al bien major de la espaciosa tierra!"

After our disappointment as above described, we began to concoct a new plan for escape; which was to disarm the stupid guards by removing the caps from their guns, and then to dash past them at the first convenient opportunity.

We succeeded in rendering one gun useless; but the sentry carrying the other being on the alert, it * " Oh, precious liberty,

Not to be compared to gold,

Nor to the greatest good of the spacious earth!" 
was impossible to uncap his piece, and, consequently, we very reluctantly abandoned our cherished project, and turned to think, or perchance to dream, of "prison pens," "bare feet," "corn dodgers," and " clead lines."

At the Danville depot we spent a sleepless night in the cars, so crowded as to be unable to take a sitting posture, much less one of reclination, in which fatiguing condition many were nearly suffocated before morning. We were then marched to the military prisons, consisting of three large brick buildings on the east side of the town. Previous to our arrival they were occupied by enlisted men.

Near the centre of the second floor of one of these prisons, my messmates, Lieutenants Nyce and Richardson, of the Harris Light, and myself have chosen a small spot, which we call our portion of the room.

\section{DANVILLE, ITS MILITARY IMPORTANCE.}

Danville is situated at the terminus of the Rich. mond and Danville railroad, one hundred and forty miles south-west of the former place, and four miles from the southern boundary of the State. It can be easily defended, and is, without doubt, one of the strongest natural positions south of Richmond. It has a population of about two thousand inhabitants.

Our daily allowance of rations at this prison is as follows: One loaf of corn bread, weighing about three-fourths of a pound; one-half pound of bacon, and one pint of soup.

This is about fifty per cent. better than we had at Richmond. Such as it is, there is enough to sustain 
life. We are fired upon by the guard for the offence of looking out of the windows, as was the case at Libby.

In this, and many other respects, I cannot see that we have gained by the change; for we meet the same stamp of men here that we left at Richmond. In some respects our condition is worse. The rooms are much more crowded, occasioning great suffering. It is impossible to find a place to sleep without disturbing some one. In order to economize space, we hare yielded to the necessity of

\section{SLEEPING SPOON-FASHION.}

At the best, large numbers are compelled to sit up till morning, and then take the pláces others have vacated.

In spite of the annoyance there is something comical in our situation. We pack ourselves down to rest as a housewife would pack her silver spoons to lay them away; and when any one gets tired of lying on any given side, he sings out, "Spoon to the right!" or, "spoon to the left!" as the case may be, and all turn in the direction indicated by the speaker.

If a man has occasion to leave his place during the night, he is sure to find it filled when he returns; and he will not even know who is the trespasser, unless he has taken the precaution to count and number his place from the wall. Thus he is never sure of rebuking the right one.

Major Moffat is in command of the post, with a small force, only sufficient to guard the prisoners.

We learn by rumor that a severe engagement 
between Grant and Lee has been raging since the fifth instant. It is generally inferred, by the uneasiness of the Rebels, as well as by their disposition to curtail our privileges, that "Uncle Bob," as they familiarly call their leader, has found his match at last. The South has had from the first great confidence in their chief, which his successes have only served to strengthen. Lee is said to be the greatest general of modern times; the matchless hero of many battles; the unconquerable Alexander, etc. Hence these latter reverses to their arms greatly puzzle and alarm them.

May 11.-We have already commenced a large tunnel, and, should we remain here long enough, will give the Rebels another subject for reflection. The study of plans of escape is our constant employment under whatever circumstances we are placed. The mind naturally reverts to the army, to home, and friends; and we are willing to risk anything to secure a release from confinement.

Could we but gain reliable news from our army, or were we permitted to receive letters from our friends, it would be a great satisfaction. But even these favors are denied us.

The public prints are vigilantly excluded from the prisons, but rumor brings us news that General Averill is making a raid in this direction. This, with the fact that a day's rations have been issued in advance, and the manifest restlessness of the Rebels, lead us to believe that we will soon be removed to some point in Georgia, out of the possible reach of Yankee horsemen. 
Some hopes are entertained, however, that our swift cavaliers will tramp into town, before the authorities can remove us. Groups are collecting here and there, and talking over the chances of success. Were so many children assembled together in antici. pation of a day of jubilee, the scene could not be more wild.

The "Star-Spangled Banner" has just been struck up, and all join heart and soul in singing it.

\section{Greensboro', N. C., May 12.}

At four o'clock in the morning we bade farewell to Danville, after a stay of four days, and were again set in motion southward. We think traveling generally very beneficial to health; and one not acquainted with the Rebel mode of treating prisoners, might be inclined to think that they are disposed to favor us in this respect; for we do not seem destined to remain in one place any great length of time.

It has been a damp, chilly day. Our circumstances, and ourselves, doubtless, also, have been very disagreeable. The cars in which we journeyed leaked badly, and the rain was driven in through the crevices by a fierce wind; this was a great detraction from the healthiness of our ride.

MEETING CONSCRIPTS FOR LEE'S ARMY.

The Rebels are apparently very much alarmed at the state of affairs in Northern Virginia. We met conscripts almost every hour of the day, on their way to join Lee's forces. 
A more motley, ill-looking lot of men could not have come together, if they had done so by design. They were going in squads of ten, twenty, tifty, or more, as the case might be, "across lots to join Uncle Bob's army in Virginny." Some had hats, and some caps; some coats, and some none. All were armed more or less, always according to their own fancy, or "what they happened to have in the house." Shot-guns, rifles, old rusty swords, long knives, horse-pistols, carbines, and broken jackknives, bid fair to damage their owners much more than their enemies. It is very questionable whether many of them will erer swell Lee's ranks to any great extent.

THE AUTHOR'S ATTEMPT TO ESCAPE.

After a ride of twenty-four miles by rail, we were compelled to leave the cars and march on foot to within eight miles of Greensboro'. The roads were muddy, and our tramp by no means pleasant; for our long imprisonment and scant rations have rendered us completely unit for a walk of half a mile eren. We suffered much in attempting to keep pace with the guard, who urged us forward at the point of the bayonet, cursing and threatening most fearfully all those that fell by the way from weakness and utter exhaustion.

When we were again put into the car's, I attempted to hide behind a $\log$ and feign sleep, but was discovered, and after sundry kicks allowed myself to be awakened. By this time the cars were filled, and as the prisoners claimed that their respective cars could 
hold no more, there seemed to be no room for me. which of course I did not much regret. The officer in command, however, undertook to find me a place, and as the doors were all closed, without further trouble, ordered me to make my entrance through a small window near the top of one of the cars. This I was assisted to do by a high bank which happened to be alongside of the train just at that point. There were objections from within, however, the men crying, "There is no room in here," but Rebel bayonets were urgent outside, and in I plunged without any definite prospect of touching bottom.

As the fates would have it, I landed on the head and shoulders of Lieutenant-Colonel G. C. Joslyn, Fifteenth Massachusetts Volunteers, hitting several others, however, in the struggle. Quite a howling was raised, in which, I think, the lieutenant-colonel did not participate. In the mêlée, my effects were scattered about the car, and, after some scrambling, I found my level among the rest.

"There's a Divinity that shapes our ends,

Rough hew them how we will."

Charlotte, N. C., May 13.

Leaving Greensboro, early in the morning, we reached Charlotte, in the same State, late in the afternoon, and were marched under heavy guard to the Commons, where we were told that an issue of rations would be made before leaving the place.

On learning that there were Yankee prisoners in town, the citizens came out in large numbers. Many approached the suard line, and endeavored to converse with us, but were forced back at the 
point of the bayonet. Finding that we could not converse with them, we concluded to entertain them with some music; accordingly we struck up the "Star-Spangled Banner," "Rally Round the Flag, Boys," etc.

In each interlude, we could see white handkerchiefs waving in the breeze, showing that we were among loyal people who hailed again their country's stirring songs. These demonstrations so exasperated the Virginia guard that they sent a detail to drive the " $\mathrm{d} \longrightarrow \mathrm{d}$ tar-heels," as they style the North Carolinians, off the field. All through North Carolina we saw unmistakable evidence of Union feeling, and the people manifested their loyalty in a bold and defiant manner.

As night approached, our guards were doubled, which satisfied us that we should remain through the night. Many plans of escape were discussed, all teeling satisfied that if we could once pass the guard, great assistance would be rendered us by the loyalists of North Carolina, who have quietly indicated their readiness to aid us in reaching the Federal lines.

Coldurbia, S. C., May 14.

We left Charlotte at one o'clock this morning, in the midst of the wildest excitement.

The night being very dark, and the soil where we were huddled together very sanảy and light, many of the prisoners dug holes in the ground and there buried themselves, hoping thus to escape the observation of the guard, when we should be marched from the field to the cars. Unfortunately, howerer, the 
scheme was exposed by one of the guards, who accidentally stumbled into a hole, in the bottom of which he beheld a live Yankee.

Struck with astonishment, he shouted, "Oh, my God! captain, here be one Yank bury hisself in the ground!" A great excitement was the natural consequence. A general search ensued. Torchlights were used, and the trees and ground thoroughly inspected. This investigation brought to light several holes of a similar character, each haring deposited therein a Federal prisoner.

The guards were very angry, and went about shouting, "Pun them through!" "Pick up the d-d hounds!" etc.; but their captain, a good-natured sort of a man, said, "No, no; the d-d Yankees have a right to escape, if they can. I'd do the same myself. I'll risk their getting away from me." But in spite of his confidence, quite a number were left behind in these pits, where not less than thirty had sought to hide, and, doubtless, would have escaped, had not the accident above detailed occurred. A few of our number, who had climbed into trees, whose foliage, at this season of year, is luxuriant and dark, evaded the torchlight of the exploration, and gained what they had sought.

At the discovery of each of these "Yankee tricks," our liberties-if indeed it conld be said that we had any-were immediately curtailed, and our condition made more intolerable. Had it not been for the changes, which happily occurred in our guards, as we moved from one important point to another, we would have been, at last, reduced to mere 
automatons, acting only as we were acted upon with no volition or power of our own. We were not far from this state of inertia, as it was, for however busy we might be in head, heart, or hand, the circle within which we were compelled to operate, was not much more spacious than the geometrical dimension described by a Northern schoolmaster, which was "the little end of nothing, whittled to a point."

After our thrilling adventures at Charlotte, we were hurriedly driven into the cars and set in motion southward.

Columbia, South Carolina, was reached late in the afternoon, and we were there informed that after a brief halt, we would continue our journey to Macon, Georgia, our final destination.

Augusta, Ga., May 15.

After leaving Columbia, we pushed on without any incident of importance, being closely guarded, and reached Augusta at six o'clock P. Mr. We were immediately given in charge of the city militia, a motley crowd of cowardly ruffians, who seemed to think that to be soldierly they must abuse defenceless prisoners on the simplest pretext. Our experience has led us to observe, that the most cruel soldiers are those who do their fighting at home, and who know nothing of the amenities of military life. These are usually braggadocios and tyrants, who fancy themselves the lords of creation, appointed either "to rule or ruin."

We shall not soon forget the suffering we endured at this place in consequence of our close confinement in the filthy cars, which we have not been permitter? 
to leave, for any purpose, since our hazardous exploits at Charlotte.

The provost marshal of Augusta is a degenerate son of Governor Bradford, of Maryland. This graceless youth afterwards led a dastardly band of guerillas to his father's residence, and plundered the home of his childhood.

In contemplating such characters one is forcibly reminded of their description by an inspired apostle, who says: "For men shall be lovers of their own selves, covetous, boasters, proud, blasphemers, disobedient to parents, unthankful, unholy, without natural affection, trucebreakers, false accusers of those that are good, traitors," etc., and thus continues the truthful and terrible delineation of the character of thousands, who, before the Rebellion, were eren peaceful citizens and kind neighbors, but whom treason has made odious and abominable.

\section{Between Augusta and Macon, Ga., May 16.}

About eight o'clock in the morning we started for Macon, and at a halt made on the way, for water and fuel, several of our number made their escape. Lieutenant Kellogg, Fifth Michigan Cavalry, climbed up into a water-tank, and was fortunately unnoticed when the train moved on. But his liberty was of short duration, for he was afterward recaptured, and made one of our number again. During the whole night we moved slowly on towards Macon. 


\section{CHAPTER VII.}

\section{AT MACON GEORGIA._" CAMP OGLETHORPE."}

WE reached Macon at eight o'clock on the evening of May serenteenth, 1864 .

Two long files of sneaking, stay-at-home Georgia militia extended from the cars to the Prison Pen, and between them we were marched into Camp Oglethorpe.

On our arrival at the front gate whom should we find but the veritable Major Thomas P. Turner, fiend incarnate, from Libby Prison. This human monster stood at the gate to count us as we passed in. To his great chagrin forty-seven of our original number were missing, all of whom had escaped from the cars. He drew us up in line, and informed us of the prison regulations, especially that any man would be shot who approached the "dead line." He soon afterwards returned to Richmond. His object in coming to Macon was, I presume, to give the authorities some instruction in regard to the treatment of Federal prisoners, and they showed themselves apt scholars.

The Prison Pen takes its name from General Oglethorpe, an early settler of Georgia. It is about eighty rods east of the city, and covers an area of a little more than two acres. The enclosure is surrounded by a stockade fence about fifteen feet high, 
near the top of which projects a platform whereon the sentinels are stationed. Within the stockade, and at a distance of fifteen feet from it, is the dead line, extending entirely around the camp. This consists of an ordinary picket-fence three and a half feet high. In many Prison Pens of the South it is only a line of stakes, with sometimes a single board attached. Camp Oglethorpe was made expressly for our reception, and had never before been occupied.

Macon is situated on the Ocmulgee River in the central part of the State, about four hundred and fifty miles from Danville, our last place of imprisonment. It is finely located, has a population of about ten thousand, and is at present one of the most stirring and important towns in the South. It is one hundred and sixty miles from Augusta, and one hundred miles from Atlanta. Two daily newspapers, the "Macon Confederate" and "Telegraph," are published here.

Since leaving Richmond my health has been very poor, owing, doubtless, to the various changes to which we have been subjected. Besides, the cars in which we were transported were extremely tilthy, and as they were kept constantly closed, the air was very impure. The heat, also, is getting to be intense during the day, and its effects are telling on the strength of the men.

\section{NEW ARRIVALS.}

On the morning of the twentieth one hundred and seren officers from Grant's army arrived, to take up their abode in the Prison Pen. Among them are Generals Shayler and Seymour. As soon as the 
"fresh-fish" * arrived the cry ran through the camp), and a general rush was made for the gate. An eager group surrounded each man, and our appearance was quite as strange to them as theirs to us. Generally their first question was, "Are you Federals or Confederates?" there being little in our appearance to make the question unnecessary.

The process of initiation was very disgusting to most of them. While some would be seriously asking questions concerning their capture and listening to their pitiful story, others would call out, "Take your tingers out of his haversack;" "Keep that louse off him;" "Give him air," etc. All this affected them strangely at first, but soon became an old story. They brought very welcome news concerning the movements of our armies.

There are at present about twelve hundred of our officers confined here, four hundred of whom were captured since the commencement of the campaign in front of Richmond.

\section{FIRING UPON A PRISONER.}

Early on the morning of the twenty-second Lieutenant H. P. Barker, First Rhode Island Cavalry, was fired upon by one of the sentinels-a boy not more than fourteen years of age. The youth missed his aim, however, and his ball buried itself in a tree a little beyond. The lieutenant is quite an old man.

* The first six months of prison life, an officer is called a "fresh-fish;" the next four months, a "sucker;" the next two monthıs, a "dry cod;" the balance of his time, a "dried herring;" and after exchange, a "pickled sardine." 
Looking across the intermediate space, to the boy, he coolly said,--

"Young man, what are you shooting at?"

"I am shooting at you, you d_d old cuss," was the reply.

"And what are you shooting at me for?"

"Because you had your hands on the dead-line," said the boy.

At this moment two other guards came up, and one of them taking the boy by the collar and shaking him thoroughly, demanded,-

"What are you shooting at that prisoner for, you $d-d$ little scoundrel ?"

The boy replied, "Because he had his hands on the dead-line."

The guard shook him again, and told him he was a liar, as the man was not within twenty feet of the dead-line, and then called the corporal of the guard, who marched the precocious monster away. If any punishment was administered to him, we never heard of it.

I was lying within ten feet of Lieutenant Barker when the shot was fired, and am certain that he was at least thirty feet distant from the fatal line.

\section{TUNNELING.}

May 29.-We received notice this morning from Captain W. K. Tabb, present commandant of the prison, that in the future, all prisoners not in ranks at roll-call, will be shot down by the sentinels on the stockade.

We have also received orders to take our boards 


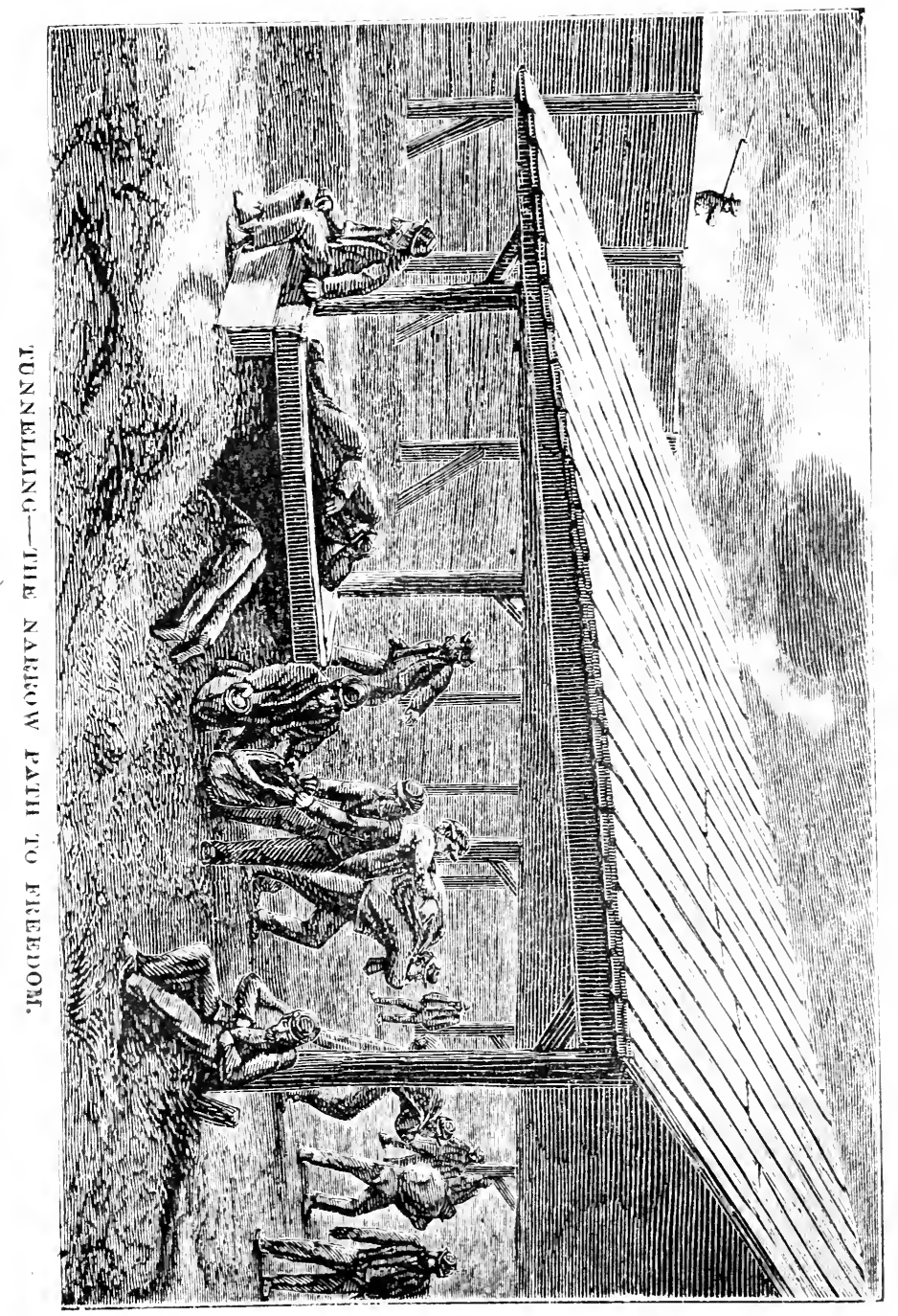



and blankets from the ground. The probable reason of this vigilance was doubtless caused by their having discovered several tunnels which we had commenced and were carrying forward as fast as possible.

Our plan of operations was as follows: We have been allowed to build ourselves small sheds, to afford a shelter from the burning sun, of some refuse boards that were lying about; and under these sheds we have made bunks to sleep on. A bunk was selected in a shed as near the dead-line as possible, and under this bunk we sunk a hole or "well," as it was termed, straight down to the depth of five or six feet. From the bottom of this well the tunnel extended out under the stockade. Only one man could dig at a time, and as the work was very fatiguing, we relieved each other often. The dirt was brought to the mouth of the tunnel in meal sacks which had been stolen from the ration wagon.

Two or three were detailed to carry off the dirt to the sinks. We usually commenced operations after ten o'clock in the evening, and continued until nearly daylight. Upon leaving the tunnel, a board was fitted in about a foot from the surface, and then dirt was swept over so as to obliterate all traces of the digging.

From sixteen to twenty days were required to finish the narrow road to liberty. Fires were built by the guard at short intervals between the dead-line and stockade, completely encircling the camp, so that the tumnels had to be carried a great distance, in order to have the place of egress as safe as possible.

If the work could hare been completed, we should 
have chosen some dark and stormy night to remove the slight cap of earth at the outer extremity of the subterranean channel, and then stealing out cautiously, so as not to attract the attention of the vigilant sentinel, we would have made for the woods and swamps.

Those who had done the digging were to have had the first opportunity to pass out, and then as many more were to go, as could get through the tunnel before daybreak.

Our plan was a good one, and we felt confident that it would prove a perfect success until the eve of its completion, when either some cowardly traitor in our midst, or a detective sent in by the authorities, exposed the scheme, and thus blighted our brilliant prospects.

UNPLEASANT CONSEQUENCES.

The result of this attempt to reach "God's country," is a reduction of rations, and a resort to every" restriction which conld possibly be conceived by an enemy.

While in Libby, I imagined that the deeds of villainy were well-nigh exhausted,-I had thought; that the catalogue of crime was nearly filled by the Confederate miscreants, but alas! you have only to see the heartlessness and the intrigues of the authorities here,-you have only to witness the suffering, the frenzy, and the fever, and you will then say, that these are the deeds of pitiless monsters.

A short time since, Captain Irich, Forty-fifth New York volunteers, sent a watch and chain by Captain Tabb, to be sold for not less than four hundred dollars. 
Some time afterward Tabb was seen wearing the chain, and upon being questioned, said he had sold the watch for two hundred dollars, and the chain had been given to him. Irich thereupon demanded either the property or the four hundred dollars, threatening to expose the whole affair if they were not given up. For this offence he was bucked several hours-but the articles were restored.

Irich was a German, and thoroughly posted in military tactics, besides being a fine swordsman. When we were being marched into Camp Oglethorpe, Tabb had given an unmilitary order, and Irich corrected him, when the infuriate Rebel ordered him to keep silent, threatening with drawn sabre to split his head open. Irich, with a little stick in his hand dared him to strike a blow, and the braggart was forced to put up his sword, amid the jeers of the citizens standing about. This may have been the reason for the severity of the punishment in the affair of the watch.

\section{RELIGIOUS MEETINGS.}

Prayer meetings, and other religious assemblies, are held almost every evening; and if the prayers of prisoners can avail, our President will be wise as Solomon, and our armies universally successful. Captain Tabb had heard that it was customary to pray for the President and the generals of our army, and one evening during service came in to put a stop to it. While he was issuing his orders in one corner of the room to Chaplain White, Fourth Rhode Island Battery, Chaplain Dixon, Sixteenth Connecticut, stepped forward and offered 
a prayer. The fearless and devout man prayed for the President and his advisers, Generals Grant and Sherman; that treason might be crushed, and the Stars and Stripcs once more wave over our common country. Tabb heard him through, and then walked out, remarking, " $\mathrm{D} \longrightarrow \mathrm{d}$ smart prayer, but it won't answer the purpose." No further attempts were made to curtail the freedom of prayer. Large numbers have been converted, of those who had all their lives been regardless of such matters.

July 18.-Our daily allowance of rations at this prison is one pint of corn-meal, one ounce of rice, one ounce of peas or beans, and one fourth of a tablespoonful of salt.

We have no cooking utensils except a few ironskillets. The beans furnished are wholly unfit for use, and the quantity of rations not more than one half of what we actually need.

June 10.--Fifty of our number were sent to Charleston to be placed under fire of our siege-guns on Morris Island. These included all the general officers, together with the highest in rank of the field officers. Among them were Generals Scammon, Wessells, Seymour, Shayler, and Heckman.

\section{A PRISONER SHOT.}

At eight o'clock on the evening of the eleventh, Lieutenant Otto Grierson, Forty-fifth New York Volunteers, was shot through the body and mortally wounded by a sentinel on the stockade.

It is asserted by the sentinel, that the lientenant was in the act of making his escape, by crawling up 
the creek to the "dead-line," preparatory to passing under the stockade; but those who were near by, and saw the affair as it occurred, said that he was not in the creek at all, and that he was at least sixteen feet from the fatal line.

I had just left the spring, and met Grierson on his way after water. Hearing the report of the sentry's musket, I hastened with several others to the lieutenant's assistance, and found him in a dying condition.

Some of our number called upon Captain Gibbs, the prison commandant, informed him of the facts, and requested an investigation, but were turned away with no satisfactory answer, or rather with the understanding, that we need not expect anything in that direction. But the villain who perpetrated the deed was promoted to a sergeant, and given a furlough, for what they considered his fidelity and promptness in the execution of orders.

PRACTICAL INFAMY OF REBELS.

June 22.-Captain Gibbs proposes to allow us the privilege, as he is pleased to term it, of choosing delegates to solicit of the authorities at Richmond an opportunity to visit our enlisted men at Andersonville, for the purpose of reporting their condition to our authorities at Washington.*

The fact is, if the truth were known, the Rebels are desirous of placing a weapon in the hands of the "peace party" at the North, whereby the cause of the Unionists may be defeated.

* The representations they propose to make are, "that the awful suffering of our men in southern prisons is caused by a change of climate and the hopelessness of exchange." 
Confederate officers and citizens are allowed tc visit us frequently. They represent to us, and would gladly hare us believe, that they are doing all in their power to make our condition comfortable and agreeable.

They repeatedly affirm that the non-exchange of prisoners is due entirely to the fault of our Government. In short, they are very anxious to have us send a deputation to Washington, for the purpose of placing before President Lincoln and the administration the horrid condition of our men in southern prisons, and to ask an immediate general exchange of prisoners, claiming, as a matter of course, that they are doing all they possibly can for us.

In accordance with their entreaties, we have held a meeting, but the result is quite unsatisfactory to the Rebels; for we have most firmly resolved never to become agents in advancing the interests of the Southern cause, even though our sufferings be increased a hundred-fold.

I am perfectly satisfied that there has been no time since the beginning of the war when the enemy could not have given their prisoners an abundance of corn-meal, and bacon, were they so disposed; and from observation I know that they could have furnished lumber, to provide us with more comfortable quarters. With such facts, glaring and palpable as they are, we will be a party to no transaction which can possibly aid in furthering their base designs.

The camp was searched to-day by order of the prison commandant, and the three tunnels which 
have been in process of digging for the past fifteen days were discovered. Had it not been for this misfortune, many of us would have bid farewell tomorrow night to this field of suffering.

Doubtless, some detective from the outside exposed the scheme. Never was I more disappointed than in this misfortune; for our plan was a good one. The tunnels were large, and it was estimated that nearly all the prisoners could pass through them in a single night. We had looked forward with the deepest anxiety to what we felt assured would be the happy termination of our labors; but alas! when it seemed that we were about to reap the promised reward, like the mirage, it vanished in the distance.

As a result of the discovery the following order has appeared on the Prison Bulletin :-

$\left.\begin{array}{c}\text { Special Orders, } \\ \text { No. } 6 .\end{array}\right\}$

C. S. Militart Prison, $\mathrm{M}_{\Delta \mathrm{CON}}, \mathrm{G}_{\Delta .}$, June $\left.22,1864.\right\}$

Sentinels are instructed to shoot down all prisoners, in the future, who are seen moving about camp after taps.

Geo. C. GrBBs,

Captain Commanding.

The guards appear delighted to receive orders of such a character, and seem to find real consolation in having the privilege of firing upon us on the most trivial pretext. A thirst for blood seems to characterize their actions. They have all their lives long been taught that the blood of "niggers" and Yankees was made to be spilled when occasion requires, and they never hesitate to put the teaching into practice. Hereafter all who leave their bunks at night to go tc 
the sinks or elsewhere, do so at the peril of their lives.

Scurvy is now becoming horribly prevalent in our midst. Chronic diarrhœa is also sweeping off its victims most fearfully. It is almost impossible to get treatment for either. Large numbers, who are afflicted with the former disease, may be seen every day burying themselves up in the ground, as the earth has a tendency to check its frightful ravages.

Much to my disgust, I find that this loathsome disease has again got hold of me. I have been hoping that it would pass me by in its visitations, but it is unquestionably present in my limbs. I attended sick-call this morning, and was prescribed for by the surgeon the first time since we left Richmond. I shall not make any effort to get into the hospital, for I am confident that it is much better to remain in canip, among my friends, where they can administer to my wants, than to go where the prisoner can expect but little sympathy, or anything else that might have a tendency to rid him of disease or recruit his wasted strength.

It is not strange that the term "hospital" has become synonymous with death; for but few who enter it ever come out alive. When a man is seen leaving camp in a blanket, it is thought that he is past help; and if he is fortunate enough to return to his fellows, it is considered an exceptional case.

Deaths have been very frequent since the warm weather came on. Many have gone to their long homes since our arrival here. We call it being "exchanged"; and it certainly is a happy transformation 
from so much misery and wretchedness on earth to a life of eternal joy in the bright realms above. Wo cannot sigh for such, but only rejoice that their cares and misfortunes are ended. It almost makes one long to go, when we think that their sufferings and trials are over, and it is not wonderful that they should murmur in their last moments,-

"I would not live alway-I joy in the trust, That when this frail form shall return to the dust, My spirit shall rise on the wings of Thy love, To seek its true home in the mansions above."

FOURTH OF JULY IN PRISON.

We had several roll-calls in the morning. The prison authorities seemed very fearful that we would attempt a general escape. Immediately after the roll-calls a large meeting was organized. Captain Todd, Eighth New Jersey Infantry, displayed a small silk flag four by six inches, which had been presented to him by Miss Paradise, of Jersey City, and which had thus far escaped the vigilance of southern relic seekers. The miniature "Star-Spangled Banner" was hailed with rounds of cheers, which showed that they came from loyal hearts.

We then adjourned to the large building occupied by the general and field officers, where Chaplain Dixon, Sixteenth Connecticut Volunteers, opened the exercises with prayer. Captain Ires, Lieutenant Ogden, First Wisconsin Cavalry; Captain Lee, Fifth Michigan Cavalry; Lieutenant Kellogg, Chaplain Whitney, One Hundred and Fourth Ohio ; Chaplain Dixon, and Lieutenant Colonel Thorp, First New York Dragoons, then followed with speeches and 
toasts, interspersed with national songs, while far above our heads, attached to a long pole, was the emblem of freedom, the "Red, White, and Blue."

Although in prison, and held there by those who ought always to have regarded the people of the North with brotherly kindness, who never should have raised the recreant hand of treason against the government established by our common fathers and sealed with their blood, there was still a universal feeling that the day which sealed our liberties should be observed with suitable ceremonies. All felt that, live or die, survive or perish, we rould give a hearty support to those Stars and Stripes-the banner of the free-that had so long wared over our heads, and for which we were then suffering every indignity and privation.

We had every reason to believe that the Rebels would not object to the celebration of the day that proclaimed us victorious over the British Lion, and brought freedom to them, as well as to us; but in this we were mistaken. Whilst we were listening to a spirited oration from Colonel Thorp, the commandant of the prison, Captain Gibbs, deemed it necessary, in the exercise of his little authority, to march a regiment of troops into the enclosure and order the assemblage to disperse. Haring no possible alternative, the order was, of course, complied with.

The meeting was conducted in a quict and orderly manner; the animus of the speaking was generally national, and nothing but Rebel tyranny could object to it.

Colonel Thorp, who had been for some time in 
command of the interior of the prison, by virtue of his position as senior officer, was relieved from duty by the following order :

$\left.\begin{array}{l}\text { "Special Orders, } \\ \text { No. } 9 .\end{array}\right\}$

"C. S. Military Prison, MACON, GA., July 4, 1864.

"I. Lieutenant Colonel Thorp is relieved from duty as senion officer of prisoners, for a violation of prison rules, and Lieutenant Colonel McCreary will again assume that position.

"II. The same order and quiet will be observed on this day as on any other.

"III. A disregard of this order may subject offenders to unpleasant consequences.

$$
\begin{aligned}
& \text { "Geo. C. Gibbs, } \\
& \text { "Captain Commanding." }
\end{aligned}
$$

July 27.-Six hundred prisoners were counted out of the enclosure this evening; their destination is supposed to be Charleston, where they will doubtless be placed under fire of our guns on Morris Island, as were the field officers sent thither during the early part of last month. This is a most singular method of defending a besieged city against its enemies, and illustrates, to some extent, the character of a people that would like to be "let alone," while attempting to establish a government in accordance with their own chivalrous notion of justice, equality, and State rights.

July 28.- The second six hundred were counted out of the pen late in the afternoon. As his name was called, each prisoner stepped between the deadline and stockade, where we expect to remain until morning, when it is generally understood that we will be shipped to the coast. 
All the old prisoners are in line, and we shall leave Camp Oglethorpe in charge of a hundred prisoners from Sherman's army, who were brought in yesterday. 


\section{CIIAPTER VIII.}

Savannah, Georgin,-“"CAMP Davidson."

WE left Macon at four o'clock A. M. of July twentysinth guarded by a battalion of the Fifth Georgia Reserves, and reached Savannah at six o'clock the same evening, the distance being about one hundred and fifty miles. It soon became apparent that the Rebel authorities were moving us from necessity. Their hurried and excited manner indicated that all was not well. Artillery was being rapidly hurled into position, the troops were on the alert, and every preparation made to defend the place; but as for ourselves, we could only hope that through their misfortune we might find an opportunity for escape: and the reader may imagine our disappointment when we learned afterwards, from one of the guards, that our cavalry, under General Stoneman, cut the road at Griffin Station only thirty minutes after we had passed. To think that freedom had come almost within our grasp, and yet eluded us, tended only to add bitterness to our hard lot. Stoneman attacked Macon, but was repulsed, and himself with a detachment of his command were captured. One hundred prisoners, or more, who had not been removed, were hurried down into a swamp, and guarded during the fight.

Savannah is situated on the Savannah River, 
twelce miles from its mouth, on the eastern coast of Georgia. It is unsurpassed by any other city in the State in its business facilities, and also in its neatness snd regularity. In a military point of view, it stands next to Charleston in importance. Its population at present is about twenty thousand, including a large number of refugees. The inhabitants are generally suffering from the most abject poverty. At present there is a perfect stagnation in business; but one can easily judge its past enterprising spirit by the unmistakable marks of its former prosperity.

Our camp is in the eastern part of the city, near the Marine Hospital, which was built and formerly used by the Federal Goreinment.

Pulaski's monument stands within plain riew. This is a fine structure, about forty feet in height.

There are about four thousand Rebel troops doing garrison duty in the city. The nearest Union force is at Fort Pulaski, located at the entrance of the harbor. They are in such close proximity to the enemy that, if we could but escape the vigilance of our guard, we should be almost certain of reaching the Federal lines in safety.

Camp Davidson, our present Prison Pen, takes its name from Captain H. H. Davidson, who was its first commandant. It is surrounded by a stockade and dead-line, and does not differ materially from the pen at Macon. Quite a number of large, moss-covered live-oak trees are growing within the enclosure, which will furnish a refreshing shade from the oppressive nown-day sun.

So great is the contrast between our treatment 
here and at other places, that we cannot but feel that fortune has certainly smiled kindly upon us for once. This is truly the oasis in the desert of our prisor. lives. The authorities have issued tents and cooking utensils to us, and seem inclined to alleviate suffering as far as lies within their power. We have pitched our tents in regular order, so that the camp las quite a military appearance.

Our senior ofticer, Colonel Miller of $\mathrm{New}$ York, acts as commandant of the interior, and all requests and complaints are made through him to the prison authorities. He also superintends the issuing of rations and policing of the camp. It is fortunate for us that our guard, the First Georgia Volunteers, have been prisoners of war, and have learned what we had a right to expect, from the magnanimons treatment they themselves have receired from the Federal government.

At Richmond, Danville, and Macon, the authorities adopted a course which they believed would render us forever unfit for further military duty. Their means were starration, close confinement. in filthy dungeons, and cruel treatment. The slightest pretext was sufficient to increase its severity. Evidently, at Savannah, they have not yet learned the usual method of ridding the Confederacy of its enemies.

The troops here have seen service, and there is nothing like the adventures of the battle-field and the mutual sufferings there experienced, to teach soldiers humanity towards each other. Whenever attempts are made to escape, they give us to understand that they would do the same themselves, under like circum- 
stances, but are still compelled to punish such infrac. tions of prison discipline. They politely ask our pardon for inspecting our quarters, and in a manner as gentlemanly as possible, remove our blankets from the floors of the tents in their search for incipient tunnels, etc. All this is very gratifying, and tends to remove the bitter hatred which former brutality had engendered.

These Georgia boys will be long remembered, and may look for the utmost kindness and consideration from us, if chance ever reverses our situations.

Our rations, though barely sufficient to sustain what little vitality we have left, are of a better quality than we have received before, since our capture. The following is our daily allowance: Corn-meal, one pint ; fresh beef, one pound; rice, one gill; salt, one fourth of an ounce.

Sutlers are allowed to sell to us in camp; but having been robbed of our money and nearly all our valuables when captured, we are generally very poor customers. We gradually find ourselves dispossessed of whatever remains to us of value, such as rings, pocket-knives, watches, etc., which we succeeded in concealing from our captors.

These souvenirs of the past were disposed of to purchase the necessaries of life, which we could have at the following prices: Flour, four dollars per quart; onions, three for a dollar; potatoes, forty-eight dollars per bushel; bread, two dollars per loaf; butter, ten dollars per pound; eggs, six dollars per dozen; milk, three dollars per quart.

At such prices we of course soon wasted away what we chanced to have; and this done, these land 
sharks ceased their visits, and we had to again con. tent ourselves with what the Rebel government saw fit to furnish.

\section{BRICK OVENS.}

The authorities have been kind enough to make an issue of brick, with which to build orens. We raise them about two feet from the ground. The brick are arranged in an oval form, and strongly cemented together with mortar made of clay, which is very adhesive, and serves as a good substitute for lime and mortar.

We use these ovens principally for baking our corn-bread, which is prepared by stirring the meal and cold water together. When baked, this bread is as heavy and almost as hard as the iron skillet used in baking it. Still it is far preferable to that produced by the usual method of cooking.

It is rumored that the first six hundred prisoners sent from Macon, attempted to disarm the guard, and take the train between this place and Charleston. The attempt seems to have proved a failure, as the guard had assistance from some temporary troops stationed along the railroad.

It may seem strange that men will incur such risks in the hope of regaining their freedom, when they know full well the bitter consequences of an unsuccessful effort.

Violent attempts, when they prove abortive, always render them liable to be shot down without mercy. Stealth and strategy are the prisoners' only weapons, and they are always more safe and more effective than force. 
August 22.-Tunneling, as a means of escape, has become quite an institution. A tunnel was commenced some days ago, from a well which we had dng and abandoned for this purpose. None but the working party were in the secret; and they themselves sworn not to divulge our plans. Tools were frequently brought in for cleaning the camp, and we managed to keep some of these generally for a day or two, until a search was instituted for them, when they were left exposed in some other part of the camp for the Rebels to find.

This tunnel was about two and a half feet in diameter, and four feet below the surface. The soil is sandy, and the digging was carried on rapidly. When some distance beyond the stockade, it was brought to the surface, and a very small hole made through the sward. Through this a reconnoissance was made, and the first thing discorered was a pair of gray legs pacing along only a few inches from the opening.

The hole was immediately closed and the tunnel pushed farther on, with the intention of carrying it beyond the second line of sentinels, which, it thus appeared, had been established.

The work was progressing finely when, in the afteruoon, a cow, passing over the tunnel, broke through, and was unable to extricate herself. The Rebels, seeing her in difficulty, came to the rescue, and thus discovered our work.

The tunnel was filled up at once, the camp carefully inspected, and the most severe penalties threatened in case of any further attempts to escape. 
That poor stupid cow had brought to light, by mere chance, what Rebel scrutiny had failed to discover. There were no blessings for the cow that day - at least, not within the stockade.

JOY WITHOUT, DEATII WITHIN THE STOCKADE.

August 26.-This has been a galaday for the Rebels at this point. A picnic has been given to the Rebel troops stationed here, by the ladies of Savannah. It was held a short distance from our campso near that our ears have been greeted by lively music, joyous peals of laughter, and happy voices.

How many sacred memories of other days did this scene recall! Freedom, certainly, seemed a precious gift to them. It will be doubly so to us, if we are ever permitted to regain it; and hence, in the future, we may be compensated for our present loss. But to many of us the day has been as sad within the stockade as seemingly joyous without.

Captain McGinnis, one of our number, died this morning. He had a large number of friends among the prisoners, and was held in high esteem for his many noble qualities; but the severity of prison life had done its work, and he was gone; and we were desirous that one so brave and noble as he had proved himself to be, should have at least a decent burial. Therefore we appointed a committee to wait upon the commandant of the camp, Colonel Wayne, to request that we might be permitted to give the captain a decent burial; but received from him the response, that the captain "was nothing but a damned Yankee, deserving to be buried like a dog, and so be should be." 
We expected little more, as Colonel Wayne is an unprincipled tyrant, and would consider it beneath his dignity to confer a Christian favor, or even to give a respectful reply. Although an excellent disciplinarian, he has no just claim to the title of a "man," and his very appearance indicates as much. Fortunately for $n s$, he is an exception among the oflicers of his command, and it is only justice to them to state that they universally despise him.

\section{KINDNESS OF LADIES.}

We were greatly surprised this evening upon receiving a note from ladies in the city, informing us that they had learned with pain of Colonel Wayne's answer to our petition, and that they themselves have purchased a burial lot unbeknown to the colonel, where the captain's remains will be suitably interred under their direction. Thank God for this dear womanly act!

August 30.-An exchange of army chaplains and surgeons has been effected; and those held as prisoners at this point are to take passage north on the next flag-of-truce boat, and will leave this place for Charleston on the four o'clock P. M. train. The wildest enthusiasm prevails among them. An exchange from close confinement in the hands of an enemy, to perfect freedom among one's friends, is certainly a sufficient cause for exultation and joy.

The D. D.s and M. D.s are now the great centre of attraction with the prisoners. Crowds have been collecting around them all day, with some message for friends at home, which they promise sacredly to 
deliver. They will be sadly missed by us, for they were untiring in their labors while here.

S:ptember 1.-Heary cannonading has been heard in the direction of Charleston all day. The atmos. phere is damp, and the heary booming of Gilmore's "swamp angel" has been distinctly brought to our ears.

I have been amusing myself, during my stay here, in studying geometry. As a matter of review it does very well, but I question whether much progress could be made in any new department of study. Samuel Johnson, I think it was, who, when he suspected that his brain might be softening, used to turn to mathematics as a test. If we were tried by such a standard, I fear many of us might find ourselves candidates for a lunatic asylum.

September 11.-Exchange stock above par. It is rumored that we are to be sent to Charleston in the morning for exchange, but few are inclined to invest. The general impression is, that if we are removed at all, it will be to share the fate of our fellow-officers, who were sent thither from Macon. It is not with pleasant feelings that we anticipate a removal. Our treatment here has been kind and even generous, in many instances, and it is feared that a change can only be for the worse. Anticipating greater hard. ships, we leave Savannah with regret. 


\section{CHAPTER IX.}

\section{At Charleston, "Under fire."}

Late in the evening of September elerenth, 1864, without warning or explanation other than our own hopes and fears suggested, we received the order "pack up,"-a generic command which had no rery literal significance under the circumstances, and yet it necessitated some little compliance.

A prisoner without shoes for his feet or coat for his back, with one hat and one shirt and no blanket, will yet be thankful for a little time in which to pack up. If he is a Yankee, he has become the orner of some personal property, though his bondage have been on Sahara's barren desert; and then there are souvenirs of home that his tact and tenderness have retained in spite of Rebel serveillance; and he must take with him relics of his dark, gloomy prison home. This passion for relics is all-prevailing among northern soldiers.

If a Yankee boy were incarcerated in the sulphurous dungeon of Tartarus, the chances are ten to one that he would bring away with him, on his release, a piece of brimstone at least, though he had to burn his fingers in getting it, and Cerberus would be more than usually alert, if he didn't get half a dozen hairs from his tail. Attention to these relics, farewells to the 
various scenes of suffering and want, and especially the subject of rations, required a considerable time.

From our stock of corn-meal we had to make "pones," corn-meal cakes, enough for the journey; these were baked in the skillets before mentioned, one skillet serving for twenty men. As soon as "marching orders" were received there was a vigorous rush for the skillets, of course, and "De'il take the hindermost," found a practical illustration. Those who failed to be first, strove to be second, by exacting a pledge from No. 1, that he would give them the skillet when he was through with it; those who failed to be second would fain content themselves with being third, and so on up the scale.

Sometimes differences of opinion arose with regard to the relative position of certain parties on the "skillet" schedule, and mild knock-downs resulted, which placed both at the foot of the list.

Men will fight for their "rights," even when staring death in the face in a southern prison. Had they all been sentenced to be hung, they would doubtless have "stood on the order of their going;" and insisted on the precedence of rank.

Baking the "pones" occupied the greater part of the night, and on the morning of September twelfth, at six o'clock, we were marched out of Camp Davidson by our old guard, the Second Georgia Regulars.

There is something sad about leaving even a "Prison Pen" after a long and familiar acquaintance. Fibres of attachment will spring from the heart to fasten on the most loathsome objects, where circum. stances of necessity and mutual suffering make tho 
soil mellow. I felt stealing over me something of those hopeless emotions which brought Byron's sad and subdued "Prisoner of Chillon" to say:

"My very chains and I grew friends, So much a long communion tends To make us what we are; - - even I Regained my freedom with a sigh."

Only ours was not freedom, but rather something worse than the worst bondage. We were to be taken to Charleston and placed under fire of our own batteries, for the enemy seem to think that we may be the means of saving the besieged city from the doom which inevitably awaits it. Of course they affirm that this is retaliation, but with the North retaliasion has ever been looked upon as a sad extremity, and to be exercised only when no other resource remains for restraining the excesses of its foes. With the South, the slightest pretext has been sufficient to cause the most wanton destruction of life.

After leaving our camp at Savannah, we were turned over to the City Battalion, which guarded us through town.

We remained for a number of hours in the dusty streets of the city, under the scorching heat of the sun, when we were ordered into cattle cars, weary and sick at heart, yet not entirely despondent, for there is

"No grief so great but runneth to an end, No hap so hard but will in time amend."

One of our number having obtained permission from the nearest guard, under the plea of necessity, stepped out of his car at the first station, when he was immediately fired upon by several others. The 
prisoner only saved his life by dodging under the car. Even while there, the commanding officer of the guard rushed up with boisterous curses and discharged his revolver at the defenceless victim, without asking a word of explanation. The prisoner was dragged from under the car and thrown back among his fellows. And yet these men, who could thus murderously fire on a deienceless prisoner guilty of no offence, were constantly talking of their honor and their "chivalry." Their deeds will publish their true characters long after their words are forgotton.

A run of ten or twelve hours brought us to Charleston. The citizens turned out in crowds as we marched down Coming street, and, as usual, we listened to the stereotyped billingsgate of the southern chivalry. We were entirely satisfied that "familiarity breeds contempt," as we listened to their coarse comments on the "damned Yankees," "northern blue-bellies," "baboons," "Lincoln's monkeys," etc. MLany, on the other hand, in the interval of our short halts, express. ed sincere regrets at our unfortunate situation, and, rather quietly to be sure, assured us of their faith in the ultimate triumph of the Gorernment. It was rather surprising to find so many of this class in the cradle of secession. There were just enough of them to save from utter ruin that treason-polluted city.

Our destination was Charleston jail-yard, the grand receptacle of all Union prisoners in Charleston. It is situated in the south-eastern portion of the city, and in plain view of Morris Island, on which our batteries were planted, which did such fearful execution. 
The jail is a large octagonal building of four stories, surmounted by a tower forty feet in lheight. On the right is the large bastile-shaped work-house, where a part of the prisoner's were confined.

The gallows is located at the south side of the jail, and the fragment of a tent which I occupied was directly in front of it. This is the nearest we ever came to hanging, so far as I could learn,unless it be the necessary suspense of our situation.

Our quarters were in the yard, and the whole enclosure was surrounded by a massive wall of masonry sixteen feet in height. Everything was in the most filthy condition conceivable, having been occupied for a long time by prisoners and convicts, without erer having been cleaned. We were unable to obtain even the necessary tools from the authorities, to do this work ourselves. Its sanitary condition was such, that it seemed impossible for us to remain there long without suffering from some foul and malignant disease. The ground was literally corered with rermin. A fellow-prisoner has said that he thought it the "nastiest, dirtiest, filthiest, lousiest place he was ever in."

We were without shelter. Fragments of tents were still standing, but aftorded no protection from the sun or storm, for the prisoners who were confined there before us, many of whom were from Andersonville, were in such a destitute condition upon their arrival, that they cut the tents to pieces to make themselves clothes to wear.

The ground floor of the jail was occupied by civil convicts; the second story, by Rebel officers and 


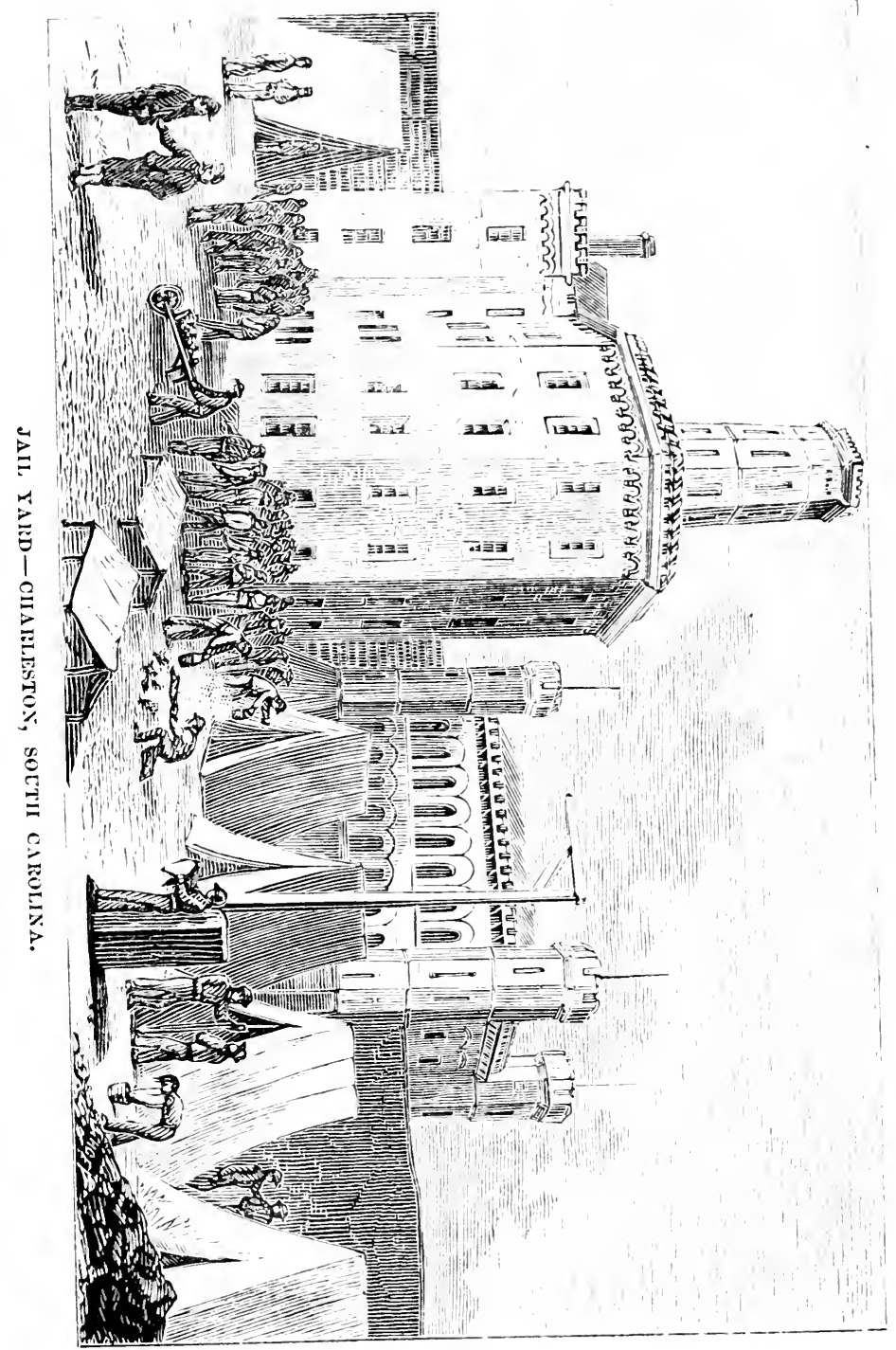



soldiers under punishment for military offences; the third story, by negro prisoners; and the fourth, by Federal and Rebel deserters.

It is a fine compliment to the good sense of the Rebels, that the deserters from either side were treated with the same severity. They seemed to consider that none but those who deserved the severest punishment would be guilty of deserting the Federal cause to join their traitor ranks; and so they placed them side by side with deserters from their own army, and subjected them to the same privations.

It must have been consoling to the cowards and sueaks who deserted the Stars and Stripes, to receive such close attention. Sometimes they ventured down from their fourth story to mingle with the Federal soldiers in the yard. Under such eircumstances nothing could restrain the prisoners from working a general onslaught, and the miserable slinks did well if they got back to their "sky-loft" with whole heads. This righteous indignation of suffering soldier's was a natural out-cropping of that heroic determination which kept their patriotism burning brightly in the midst of their untold sufferings.

Many of the negro prisoners in the jail were captured at our assault on Fort Wagner. I had a conversation with Sergeant Johnson (colored), Company F, Fifty-fifth Massachusetts Infantry; he was a full-blooded negro, but possessed of no ordinary degree of intelligence; he gave me an interesting history of the captivity and trial of the negro prisoners. Soon after their capture they were informed 
that they were to be tried by a civil commission, on a charge of having abandoned their masters and enlisted in the United States army, and if found guilty, they were told that they might make up their minds to stretch hemp. And why should they not be found guilty? to be sure, nearly all were from the North, and had always been free; but they knew full well that this court was formed, not to subserve the ends of justice, but to convict, for the Rebels had sufficiently illustrated their method of dealing with negro prisoners, that is, when they deigned to receive them as such, instead of murdering them in cold blood, in order to convince their comrades of the narrow chances for life, should they unfortunately fall into the hands of an enemy.

\section{A FRIEND.}

The sergeant told me that they were surprised to find a friend in a relative of $\mathrm{Ex}$-Governor Pickens of South Carolina. The governor himself was true to southern principles, having been elected to the legislature of his State by the nullifiers in 1832, and being among the foremost to urge his State out of the Union in 1860 ; but this friend to the oppressed remained firm in the cause of his country, and bravely loyal, as the sequel will show. He came to them and offered unrecompensed to plead their cause before the sham tribunal that was to decide their fate. When he first revealed his intention to act in their behalf, he was regarded as an impostor, a government detective, whose only object was to learn their history; that is, to ascertain if they had 
been slaves, to whom they had belonged, and under what cireumstances they had left their masters. But he persisted, and gave them money to purchase little necessaries (for nothing but corn-meal was issued to them, and this in very small quantities), and left then with the promise that he would soon return, and report the progress of his investigations; but when he came, he found them still doubting, and unwilling to place confidence in him; but, calling them together, he related that before the war he himself was a slaveholder, and was known and respected throughout his State. But at the commencement of this intestine strife, having proved true to the "old flag," his property had been swept from him, calling him traitor, and an abolitionist, and that now he was an outcast among his friends, and in constant danger of being assassinated.

\section{GENUINE PATRIOTISI.}

He also told them that he knew that this must be his fate, from the first, if he remained true to his convictions; but that, having counted the cost, it was as nothing when weighed in the balance against truth; and he was now prepared to do his work thoroughly and unhesitatingly, regarding only as friends those who were true to the cause of their country.

By this means he gained their confidence, for there is a higher language than the written. It is seen in the mute dropping of the tear, in the trembling of the lip, in the flashing of the eye, in the melody of the roice. The tones of sympathy and friendship :annot be successfully counterfeited. Deceivers may 
impose on those whose perceptions have been dulled by the conventionalities and allowed hypocrisies of society; but the quick-sighted instincts of the child of nature will readily detect the fraud. They listen to the words of a man, and then look into his eyes to interpret his meaning; and this decision cannot be revoked. And when this language shall become as universally studied and understood as the written language which we speak, then shall the divine command, "Thou shalt not lie," never be violated, on account of the inability of mankind to deceire us with their words.

As the sergeant related to me how untiring were the efforts of this friend during their prolonged and donbtful trial, in combating error with firm, convincing truth, in proving their innocence, even under laws that were made but for white men, he seemed at times to be completely overcome by his feelings, so unused was he to sympathy or kind words; but when their trial was once over, and their innocence established, they returned to jail, to be regarded as prisoners of war.

\section{THE IAAST VISIT.}

It was after their return to the jail that their friend and adrocate visited them for the last time. Their emotions were uncontrollable, and they seemed unable to give even a faint expression of their gratitude to him who had sacrificed so much for them. Their admiration for this devoted friend of the Union was so great, that the mere mention of his name is sufficient to bring tears to the eyes of these swarthy sons, who have thus far bad so little to be grateful to us for. 
This young man, who thus came forward to defend innocent and unfortunate men, was to them, and is to us, "nameless"; but his memory will be green in their simple hearts until their black faces go down to the grave. The gratitude of the humblest of our fellow-men is a treasure the true heart will cherish.

This stranger died shortly after. Whatever may have been his previous life, he carries with him the act of anselfish philanthropy, a gift that is dear to Hearen.

\section{NEGRO MELODIES.}

At the close of day the negro prisoners made a practice of getting together in the jail, and singing their plaintire melodies till late in the evening. The character of their songs was usually mournful; and it was often afrecting to listen to them-always embodying, as they did, those simple, child-like emotions and sentiments for which the negro is so justly celebrated. The harmony and rich melody of their roices are rarely surpassed. Indeed, this seems a special gift to them. This very fact gives the surest promise of their future elevation and refinement. No race so delicately sensitive to the emotional can be essentially coarse and barbarous.

One song, which appeared to be a special favorite with them, was written by Sergeant Johnson, whom I have before mentioned. He intended it as a parody on "When this cruel war is over." I give the song ns he furnished it to me. 
I.

"When I enlisted in the army, Then I thought 'twas grand, Marching through the streets of Boston Behind a regimental band. When at Wagner I was captured, Then my courage failed; Now I'm lousy, hungry, naked, Here in Charleston jail.

Chores. Weeping, sad and lonely-

Oh! how bad I feel; Down in Charleston, South Car'lina, Praying for a good 'square meal.'

II.

"If Jeff. Daris will release me, Oh, how glad I'll be;

When I get on Morris Island

Then I shall be free;

Then I'll tell those conscript soldiers

How they use us here;

Giving us an old 'corn-dodger'-

They call it prisoner's fare.

III.

"We are longing, watching, praying,

But will not repine

Till Jeff. Davis does release us,

And send us ' in our lines.'

Then with words of kind affection,

How they'll greet us there!

Wondering how we could live so long

Cpon the 'dodger's fare.'

Crorus.-Then we will laugh long and loudly-s Oh, how glad we'll feel, When we arrive on Morris Island And eat a good 'square meal.'" 
The negroes sang this song with a great deal of zest, as it related to their present sufferings, and was just mournful enough to excite our sympathy.

A small portion of the present inmates of the jailyard were removed here from Andersonville; and I have listened with pain and perfect horror to the history of their past treatment. Future generations will stand aghast in view of the unheard of and pitiless deeds of men steeped in infamy-their foul and barbarous usage of our unfortunate soldiers.

At Andersonville large numbers were crowded into a small space, where the ground was literally alive with vermin. During the heat of the day, by watching closely in the warm sand, you could perceive a constant motion among the particles; so alive was it with lice. On such ground as this, the men were closely crowded together, without shelter, and with fare which a Rebel surgeon himself declared "would produce diseases among swine."

AWFUL CONDITION OF THE HOSPITAL.

The hospital was in the most wretched condition; no one left the pen, however feeble he might be, who had any friend to attend to his wants, for the only advantage gained by leaving the stockade, was a shelter from the scorching rays of the sun, but this was counterbalanced by being brought in such immediate contact with so many afflicted with the most foul and offensive diseases.

The men were placed upon the ground, nothing underneath them, and usually without corering, while the nights were so chilling as to keep the poor fellows 
quaking with cold until the sun appeared again to warm them, and then followed the other extreme, the intense heat, which rendered the sufferings of those intolerable whose blood was almost quenched with burning fevers.

The Rebel surgeons seemed to give them little or 110 care.

So filthy and obnoxious, so infested with vermin, and so loathsome had this den of living death become, that it was indeed impossible for a person of good health to endure it long.

While such a state of things existed, it is not strange that the mortality among them was fearful. Each day the dead were carried away by scores, their places to be again filled by others, who in all probability would soon share the same fate, for none but those who were so low as to be past cure were ever looked at by the surgeons, and nearly as many died within the pen, without ever receiving any medical treatment, as in the hospital.

A fearful responsibility certainly rests somewhere, and the fiends who could thus wantonly murder so many helpless and innocent men, are almost as much to be pitied for their moral depravity as the prisoners for their bodily suffering, and yet these martyrs to the cause of "Liberty and their Country" never murmured against the Government, always believing that it was powerless to help them, or else that it did not understand their true condition.

I have noticed scarcely a prisoner from Andersonrille who was not more or less affected by some disease contracted there, oo that we now see the truth 
fulness of what they say proven by their physical condition.

One poor fellow, who was lying in the jail-yard when we arrived, recognized in one of our number his former captain. In a feeble voice, he addressed him as such, but the poor prisoner was so tattered and emaciated, and blackened by disease and exposure, that the captain did not recognize him. A faltering, broken explanation located him in his memory, and they took a melancholy pleasure in rehearsing their mutual and individual experiences. The dying man was too far gone to need assistance, had any been possible, and all the captain could do was to lie down by his side during the long cold night that followed, and close his lifeless eyes in the morning.

\section{A THUNDER-STORM.}

September 20.-I find myself weak and exhausted this morning, with blood feverish and my system racked with pain, the result of yesterday's suffering; for it was one of the most wretched days that I have passed since my capture.

Nothing could have been more lovely than the morning, but the sky was soon overcast with dark clouds, and one of the most fearful thunder-storms broke forth that I have ever witnessed, followed by a severe and drenching rain, which continued during the day and night. We were without shelter, or wood to build fires, and were obliged to exercise constantly to keep from chilling.

At night, as there were no signs of the storm abating, we sent a committee to wait upon the jailer. 
to obtain permission, if possible, to go iuside the jail, as there were a number of unoccupied cells, but were refused admission, without a reason being given.

Before morning the yard became flooded with water some four or five inches deep, and with our garments drenched and our limbs benumbed with cold, we were compelled to walk through this flood, in order to keep the blood in circulation.

There were a few small out-houses connected with the jail, formerly used as sinks, and which were in the most loathsome and filthy condition; yet into these a small portion of the prisoners crowded themselves, and were partially protected from the storm, but suffered almost as severely from the obnoxious vapors, as we from the drenching rain.

Our situation called to mind the experiences of persons whose minds had become weakened by a necessitated abode on some desert island, whose manhood had been lost by an unbroken familiarity with forest solitudes and savage beasts, whose natures had been almost changed by the wind and spray and shellfish diet of some bleak ocean rock; and I wondered, since the influences in the outer world are so potent for good or evil, what must be the effect upon us, whose vision cannot extend beyond the dismal walls which surround this abode of misery. The monotony, too, is only relieved by a "jail," a "work-house," and the whizzing, bursting shells.

September 22.-Heat oppressive. Heard from the members of my regiment who are confined in Roper Hospital. They are making an effort to have Richard. son and myself transferred to that building, which is 
a far better place than the jail-yard, although it is quite as much exposed to shot and shell.

The naval otticers are in excellent spirits at present, having learned by the last flag-of-truce boat that terms for a special exchange of all naval prisoners have been agreed upon.

Shelling is kept up vigorously. From sixty to a hundred huge smoking two-hundred pounders convey Federal compliments daily to the cursing city.

It is a singularly noticeable fact, that every Charleston paper, in its report of "damage done the city" by our batteries, never chronicles the loss of a white person; but in every morning edition we notice the name of some "poor negro," whose life has been taken by the "cruel barbarity of the $d-d$ Yankees." 


\section{CHAPTER $X$.}

ROPER HOSPITAL, CHARLESTON.

September 29.-To-day is an eventful one for Richardson and myself. Our rations being entirely gone, we started in quest of something to eat, after taking our usual morning bath. We succeeded in finding a friend who had a little corn-meal left, and who willingly shared it with us. Hastening back to our quarters, we converted it into mush, and sat down fully prepared to do ample justice to the dish, when a cry was heard, "All those whose names are called, will prepare to go to Roper Hospital immediately."

We listen, but our names are not called; we wait and wait for the next list to be read. It seems evident that we are destined to remain in the jail-yard; when, to our great surprise, we hear the welcome voice of Major E. F. Cooke, of the old regiment, who has at last succeeded in persuading the authorities to remove us from this hell on earth. How we start! How eagerly do we grasp his extended hand! He tells us to "pack up," which requires but a moment, as our wardrobe is scanty, and our equipments few. Passing through the heavy doors of the jail, it seemed as though a new life had sprung up within us. We felt free, although Rebel bayonets 
still surrounded us. We were taken before the Rebel commandant, to whom we gave the following parole :

$$
\begin{aligned}
& \text { "Charleston, S. C., C. S. A., } \\
& \text { "Septembir -, 1864. }
\end{aligned}
$$

"We the undersigned, prisoners of war, confined in the city of Charleston, in the Confederate States of America, do pledge our parole, individually, as military men and men of honor, that we will not attempt to pass the lines which shall be established and guarded around our prison-house; nor will we, by letter, word, or sign, hold any intercourse with parties beyond those lines, nor with those who may visit us, without authority. It is understood by us that this parole is voluntary on our part, and given in consideration of privileges secured to us, by lessening the stringency of the guard, of free ingress and egress of the house and appointed grounds during the day, by which we secure a liberty of fresh air and exercise grateful to comfort and health.

"Hereby we admit that this our parole binds us in letter and spirit, with no room for doubt or technicality of construction, and its violation will be an act of lasting disgrace. Signed."

After signing this, we were marched under guard through the gateway of "Roper" into the beautiful garden of the hospital. How great the change! Here we are comparatively free. Here all seem better contented. We are assigned quarters on the third-floor piazza: the hard floor seeming a luxury, and the place itself a paradise, compared to that worse than grave-Charleston jail yard.

September 30.- Sixty shells and solid shot of very heavy calibre were thrown into the city to-day, many of which exploded in what is commonly called the Burnt District. It covers about one-third of the city; 
and was burnt during the early part of the year, having been set on fire by the explosion of shells thrown from our batteries on Morris Island.

This part of the city has been deserted by all except the negroes, who, whenever there is a cessation of shelling for a short time, flock here in great nambers to save rent. But a few shell dropped into the streets will soon disperse them, although they are easily tempted back again. And after a few days of quiet, they may be seen trudging around with bundles on their backs, looking for the most favorable location, often taking up their quarters in the dwellings of the former notables. Before the siege the poor negroes could only gain admission by the back entrance, where, with hat in hand, they awaited the orders of "massa."

Well, truth is stranger than fiction, and the city, built by the hard labor of slaves, now holds them as her principal oceupants.

\section{SHELLS A SUBJECT FOR DISCUSSION.}

As the shells from our batteries came screaming over our heads, we took them as the subject of numerous and warmly contested discussions. Some, for an argument, claimed that a shell is entirely harmless in its progress through the air, if it does not explode before reaching a point directly orerhead; others asserted that it must be past sufficiently far to make an angle of forty-eight degrees with the horizon before all danger is over. There are many absurd notions in cireulation relative to the explosion of shells. Pictorial papers represent them as ex. 
ploding while sweeping through the air, and the fragments flying in all directions. Soldiers return from the army, and talk of small shells entering men's heads, exploding just as they were passing through. and so scattering brains and skulls to the four winds of heaven.

The laws of physics will teach us, that if a shell is moving through the air with a velocity greater than that which its explosion is capable of giving to the fragments, none of them can possibly fall back of the place of explosion. If the velocities here spoken of should be exactly equal, the pieces of the shell on the side next the mortar would be just stopped by the explosion, and so would fall perpendicularly to the ground; while those on the side opposite the mortar, being propelled by two forces (that of the mortar and that of the explosion), would necessarily be thrown a greater distance forward. The pieces at right angles to the direction of motion would be thrown at right angles to this direction, if the velocities were equal; if not equal, they would move obliquely backwards or forwards according to the velocities, making the hypothenuse of a parallelogram. The explosion of shells over large bodies of water will thoroughly test these conclusions; and observations made under such circumstances prove them to be correct. If a shell explodes when moving rapidly over a body of water, the pieces all strike the water several rods in advance of the place of explosion,- - some more, some less,-- the puff of smoke still remaining to mark the spot. Some move obliquely forward, some strike nearer and some farther from the place of explosion. It would not be 
difficult to tell, from the striking location of any frag. ment, whether it was at the north, south, east, or west side of the shell at the instant of explosion. If a shell is stationary, or moring very slowly, the pieces of course fly in all directions.

Groups of prisoners collected from time to time for the purpose of discussing this and various other subjects in which we had a direct, though unpleasant interest. Hours were spent thus, whilst erery fifteen or twenty minutes we could see the smoke and hear the explosion of "Foster's messengers" as we called them, which came to us in the shape of screeching, tearing, death-dealing, two-hundred pound shells; and although we were completely isolated from the outer world, yet these "terrible despatches" seemed ever welcome. They told us of the untiring perseverance of our forces on Morris Island.

So correct was their aim, so well did the gunners know of our whereabouts, that shells burst all around in front, and often flew screeching directly overhead, without injury to us. When the distant rumbling of the "swamp-angel" was heard, and the cry, "Here it comes!" resounded through our prison-house, there was a general stir. Sleepers sprang to their feet, the gloomy forgot their sorrows, conversation was hushed, and all started to see where the messenger would fall. Perhaps it would burst in mid air; perhaps fall crashing through the roof of some dwelling, converting it quickly from a stately mansion to a heap of smoking ruins.

The sight, at night, was truly beautiful. We traced along the sky a slight stream of fire, similar tc 
the tail of a comet; followed its course until, "whiz, whiz," came the little pieces from our mighty twohundred pounders, like "grape-shot," scattering themselves all around, and assuring us, in unmistakable language, that our soldiers were still battling for the cause of freedom inviolate.

October 1.- Yellow-fever is raging fearfully in the city at present. Five shells from our batteries fell in the burnt district to-day. It was amusing to witness the flocks of negroes, who came running from the buildings which they have occupied since the commencement of the siege clear of rent charges, the owners being too timid to remain in that locality. The colored people are often driven out in this manner, but invariably return after the shelling, to enjoy their threatened haunts.

\section{SISTERS OF CHARITY.}

Confined as we are so far away from every home comfort and influence, and from all that makes life worth living for, how quickly do we notice the first kind word, the passing friendly glance! Can any prisoner, confined here, ever forget the "Sisters of Charity?" Ask the poor private, now suffering in those loathsome hospitals so near us, while burning with fever or racked with pain, if he can forget the kind look, the kind word given him by that "Sister"? Many are the bunches of grapes, many the sip of its pure juice, does the sufferer get from her hands. They seem-they are, ministering angels; and while all around us are our avowed enemies, they remain true to every instinct of womanhood. They dare 
lift the finger to help, they do relieve many a sufferer.

All through the South our sick and rounded soldiers have had reason to bless the Sisters of Charity. They have ministered to their wants, and performed those kind womanly offices which are better to the sick than medicine, and so peculiarly soothing to the dying. These noble women have tended their sick beds when the other professedly Christian ladies of the South looked on in scorn, and turned away without eren a kind word. They hare done what some were too bitter and cruel to do; they have done what others did not dare to do. They were somehow permitted to bestow charities wherever charities were needed, without fear or molestation. Their bounties were bestowed indiscriminately on Federal and Rebel sufferers, and bespoke a broad philanthropy, unlimited by party or church or nation. Many a poor soldier has followed them from ward to ward with tearful eyes, and remembered the poet's lines:

"Woman! Blest partner of our joys and woes!

Even in the darkest hour of earthly ill, Untarnished yet, thy fond affection glows,

Throbs with each puise, and beats with erery thrill!

When sorrow rends the heart, when feverish pain

Wrings the hot drops of anguish from the brow,

To soothe the soul, to cool the burning brain,

Oh, who so welcome, and so prompt as thou!

The battle's hurried scene, and angry blow,

The death-encircled pillow of distress,

The lonely moments of secluded woe-

Alike thy care and constancy confess,

Alike thy pitying hand and fearless friendship bless." 
Were other denominations in the South as active in aiding us as the Catholics have been, I might have some faith in Rebel Christianity.

October 2.-Several shells passed directly over us this afternoon, a fragment of one striking the west end of the building.

October 3.-Our batteries have shelled the city vigorously during the past forty-eight hours. Many explosions occurred very near us. No casualties among the prisoners.

\section{YELLOW-FEVER.}

The Rebel captain commanding the prison, and his adjutant, died last night with yellow-fever. Many prisoners have been swept off by the same within the past few days.

October 4.-Heard from our enlisted men confined on Charleston Race Course. Starvation, exposure, and the frightful ravages of yellow-fever are doing their work most effectually.

October 5.-Orders are issued to "pack up" once more. We are to leave Charleston. The Rebel authorities ostensibly claim that they are removing us from the ravages of yellow-fever. In view of the fact that we were brought here to be murdered by our own guns, this assertion seems doubtful,-and in view of the fact that it is no longer for their interest to keep us here, it appears more doubtful. It seems scarcely credible that Louisianians should invoke the yellow-ferer upon our armies, and South Carolinians remove them from under its influence. We were brought to Charleston to save the city from the shells of our batteries on Morris Island. The result $7^{*}$ 
proved that our gunners there conld fire over and about our prison, and scathe the blackened city as fiercely as ever. In addition to this, General Foster placed an equal number of Rebel officers on Government transports in front of his works, which effectually prevented them from firing upon him. It was for their interest, under these circumstances, to take steps to get these Rebel officers removed. These facts place their humanity in rather bad odor.

\section{FARETELL TO CHARLESTON.}

We bade the cruel city farewell without a regret. It has long been the abode of outrage and injustice. We expected no mercy at its hands, and have received none. The seething, almost conscious, shells from our island batteries are paying the respects of the North and northern men to this now desolate source of treason and discontent. We leave you to your fate, thankful that our presence, eren as prisoners, has not mitigated your punishment.

The following verses were composed by Lieuten ant J. Ogden, First Wisconsin Cavalry, and will fit tingly close the chapter on Charleston:

\section{CHARLESTON, SOUTH CAROLINA.}

I.

Oh, thou doomed city of the evil seed, *

Long nursed by baneful passion's heated breath!

Now bursts the germ, and lo, the evil deed

Invites the sword of war, the stroke of death!

Suns smile on thee, and yet thou smilest not;

Thy fame, thy fashion are alike forgot.

* The doctrine of State Rights as taught by John C. Calhoun. 
Consumption festers in thy inmost heart ; The shirt of Nessus fouls thy secret part.

II.

Lo, in thy streets-thy boast in other days--

Grim silence sits, and rancorous weeds arise!

No joyous mirth, nor hymns of grateful praise,

Greet human ears, nor court the upper skies;

But deadly pallor, and a fearful looking for

The hand of vengeance and the sword of war.

Thy prayer is answered, and around, above,

The wrath of God and man doth hourly move.

III.

Thy foes are in thy beart, and lie unseen;

They drink thy life-blood and thy substance up;

And though in pride thou usest to sit a queen,

Justice at last commands the bitter cup.

The blood of slaves upon thy skirts is found;

Their tears have soaked this sacrilegious ground.

The chains that manacled their ebon arms

Now clank about thine own in dread alarms.

IV.

Thy sanctuaries are forsaken now ;

Dark mould and moss cling to thy fretted towers;

Deep rents and seams, where straggling lichens grow,

And no sweet voice of prayer at vestal hours;

But voice of screaming shot and bursting shell,

Thy deep damnation and thy doom foretell.

The fire has left a swamp of broken walls,

Where night-hags revel in thy ruined halls.

$\mathrm{V}$.

Oh, vain thy boast, proud city, desolate!

Thy curses rest upon thy guilty head!

In folly's madness, thou didst desecrate

Thy sacred rows, to holy Union wed. 
And now behold the fruit of this thy sin:

Thy courts without o'errun, defiled within; Gross darkness brooks upon thy holy place;

Forsaken all, thy pride in deep disgrace.

\section{VI.}

Wail, city of the proud palmetto-tree!

Thy figs and vines shall bloom for thee no more! Thou scorn'dst the hand of God, that made thee free,

In driving freemen from their native shore. Thy rivers still seek peacefully the sea, Yet bear no wealth on them, no joy for thee. Thy isles look out and bask beneath the sun, But silence reigns-their Sabbath is begun!

\section{VII.}

Blood! BLood is on thy skirts, O city doomed!

The cry of rengeance hath begirt thee round; Here, where the citron and the orange bloomed, God's curse rests on the half-forsaken ground! Thy treason, passion-nursed, is overgrownThy cup of wrath is full, is overflown. Repent, for God can yet a remnant save, But traitors and their deeds shall find the grare!

Hospital, Charleston, S. C., Sept. 25, 1864. 


\section{CHAPTER XI.}

REMOVAL TO COLUMBIA.

Early on the morning of October fifth, 1864, Captain Mobly of the Thirty-second Georgia Volunteers gave us notice to prepare to remove to Columbia, the capital. In an hour's time we were securely packed in cattle-cars, ready for a start. These cattle-cars deserve a little notice. They were not exclusively cattle-cars, but were used to convey Union prisoners as well. One day they would be loaded with cattle, which did not tend to improve their sanitary condition to any great extent; the next day-without any policing-they would be filled with barrels of sorghum molasses, a few of which would be smashed; and the next day fifty or sixty Yankees would be crowded into each of them, to be jumbled over a southern railroad a hundred miles or more.

Ye who pursue pleasure in splendid coaches along our northern railroads, think of this, and estimate the luxury of a trip from Charleston to Columbia under such circumstances. Our guard was the Thirty-second Georgia Volunteers, to whom too much credit cannot be given for their uniform kindness and courtesy.

The Georgia troops seemed to be by far the most 
civil and gentlemanly of the southern army. They were the most respectable in appearance, most intelligent and liberal in conversation, and most fully recognized the principle that a man is a man under whatever circumstances he may be placed, and is entitled to humane treatment. They very generally addressed the prisoners as "gentlemen."

It is refreshing to find occasion to notice something commendable in those who were so almost universally tyrannical and cruel.

Our journey was marked with no features of peculiar interest, as the country through which we passed was a barren and sandy tract, with no vegetation to meet the weary eye, save occasionally a small patch of cotton, and sometimes sugar-cane growing by the roadside.

We were about fourteen hours on the way, and arrived at Columbia, in the midst of a terrific rainstorm, without food, blankets, or a necessary amount of clothing. We were compelled to vacate our quarters in the cars, and take up with such as were provided us by the Confederate officers in command, to wit: none at all.

We were closely guarded, and one of our number, Lieutenant H. L. Clark, Second Massachusetts Artillery, received a serious wound in the back by a bayonet in the hands of one of the sentinels, for attempting to take a small loaf of bread offered him by a sympathizing citizen.

We remained in an open field on "Bridge street" during the night, suffering from hunger, without blankets, tents, or any conveniences for comfort, at 
the mercy of the elements, with four pieces of artil lery trained upon the ground which we occupied.

It was just before this that Alexander $\mathrm{H}$. Stephens, their Vice-President, inaugurated his peace movement, and the Rebels expressed great anxiety for a knowledge of the result. They were anxious for peace, and hoped the movement would terminate in a settlement of their difficulties on a basis satisfactory to the interests of the southern people. Ever loud-mouthed and boastful, they still had misgivings as to the result, and eagerly caught at any prospect of a settlement.

\section{COLUMBIA.}

This capital city of the first State to raise the dark hand of treason against the American Union, has a population of from twenty to thirty thousand inhabitants, and is one of the finest in the South. It is handsomely situated on the Congaree river, one hundred and twenty-fire miles from the sea, covering a gentle slope of ground which overlooks the surrounding country for a distance of from twenty to thirty miles, and it is equidistant from Charleston and Wilmington, North Carolina, on the line of the South-Carolina Central Railroad.

It is regularly laid out, its streets crossing each other at right angles; some are wide and planted with handsome trees, among which are found the Palmetto, which is familiar to all, as it was represented upon the first flag raised as a signal of war in opposition to the laws of our country.

Except in the busy, commercial parts of the town, the houses are surrounded with gardens, crowded 
with shrubs and flowers of all kinds; each establish ment being generally encircled with hedges of ham. thorn, interspersed with a luxuriant growth of roses.

The dwellings, which stand amid those beautiful pleasure-grounds, are built of many different forms. Those of wood are usually painted white.

To the Southerner, this lovely place, during the war, has been one of perfect safety. It being the farthest of any from the lines of our advancing armies, and free from attack by our ever-watchful navy, many have flocked here from all parts of the Confederacy, where they might be beyond the reach of the dread sounds of war.

The Confederate government, influenced by the thought of impending danger, mored its treasury from the city of Richmond to this place, fearing that the Union army might make an inroad into its capital, and destroy its worthless currency.

The public buildings are of magnificent structure. The Capitol, or State House, occupies a commanding position near the entrance of the town. The grounds adjoining are adorned with beautiful walks and arenues.

The military academy, court house, and its church edifices are built in splendid style. With all the beauty and magnificence combined to make these buildings grand to look upon, there yet remains connected with their history the memory of the dark deeds perpetrated within their walls, which resulted in the secession of the Palmetto State from our great and glorious Union. Here it was that the first steps were taken, which placed South Carolina foremost in 
the ranks of those States which afterwards adopted the ordinance of secession.

Although coöperation had been urged by many leading men of the South, among whom were $\mathrm{Mr}$. Rhett, long conspicuous in the councils of the State, and Mr. Trenholm, afterwards a member of the Confederate cabinet, yet the fiery devotees of slavery forced their opinions, and controlled the public feeling, until a convention was called, which met on the twentieth of December, 1860, when South Carolina launched forth upon a sea, above whose tranquil bosom brooded a pent-up storm, dark and tremendous, which, when it burst forth from its deathly silence, drenched her soil with the blood of her own sons, and scathed and blackened her as with fire from heaven, carried all away who had embarked upon its alluring surface, and dashed in one final wreck the frail structure upon which this unrighteous and unjust government was to have been formed.

She entered upon a struggle which has devastated her lovely fields and finest cities, depopulated many of her most flourishing towns, and reduced her inhabitants to poverty, degradation, and despair.

By this deed, thousands of America's honored sons, while battling nobly for the maintenance of right, have been sacrificed-making the fields of the South run red with blood.

But it has terminated in the complete overthrow of the foundation upon which these southern leaders attemipted to rear their government, and in the destruction of that evil which had so long stained our nation's honor. Oh, Columbia! the pride of the 
South, thou hast passed through the fierce and bloody struggle without sharing in the general ruin which follows the footsteps of war. Although many of your hearth-stones have been made desolate, your beauty and magnificence yet remain.

May your people profit by the sad lot of other cities, and no longer invite destruction by fanning the flames of treason, and urging its cruel champions onward.

As soon as the storm had abated, which raged violently from the time we reached Columbia, corn. meal and sorghum molasses were issued to us in small quantities, and then we were mored from our camp on Bridge street to the south side of the Congaree, about two miles from the city, and, like Nebuchadnezzar of old, turned out to grass.

Sorghum cane grows in large quantities in South Carolina, and from it a kind of molasses is made which entirely ontdoes the blackest and dirtiest cane sirup. Corn-meal cakes and sorghum molasses will act as a cathartic on the strongest stomach, and to one already afflicted with chronic diarrhœa they were about as nourishing as a steady diet of epsom salts. 


\section{CHAPTER XII.}

COLUMida, SOUTH CAROLINA- CAMP SORGHUM."

AN attempt was made yesterday by the anthorities to persuade us to take our paroles, in order that we might enjoy the privileges of an open field. We were threatened with confinement in some old tobacco houses, in case we did not comply with their wishes; but we sternly refused to accept their base proposition, and utterly disregarded their threats, knowing that our condition conld be made no worse by the change.

It may seem strange to some that these paroles were not accepted. Our reasons for not accepting them were these: 1st. They prevented our escaping, and this was the thought nearest our hearts. $2 \mathrm{~d}$. We thought the punishment threatened rather more endurable than our condition when not under punishment.

They stated that they would confine us in some old tobacco houses, if we did not comply. Now, we considered confinement in any kind of a building more desirable than lying on the ground, without covering, during the damp chilly nights, exposed to the wind and storm.

For some reason unknown to us, we were not removed from this place into the tobacco houses, but a 
guard and "dead-line" were established; and in the open field, with no covering save the broad cauopy of heaven, our band, numbering upwards of fifteen hundred men, was obliged to remain.

After many unsuccessful attempts to get a newspaper, I at last, by bribing one of our guards, secured a copy of the "South Carolinian," a weekly sheet published in the city, from which I learned the position of the Union army under the gallant Sherman.

\section{A DAY OF JOY.}

October 8.- This day was one of joy and thanksgiving. Our hearts were made glad, and our hopes brighter, by the receipt of clothing, and many other articles of comfort, sent to us from the North by that ever-beneficent organization, the Sanitary Commission.

Those of our number who were the most needy were supplied with such articles as the authorities saw fit to allow them, which to some degree alleviated their sufferings, and made life somewhat sweeter. It was my happy lot to get a towel and an undershirt. The last-mentioned article was of great value to me, as more than three months had passed since I had had a change. Notwithstanding the distribution of clothing, many were without shoes, stockings, shirts, and coats-dying by inches for want of some protection from the inclement weather.

October 16.-Our Prison Pen had been remarka. bly quiet for six or eight days, nothing haring transpired among the prisoners to cause any ex- 
citement, and we were fast falling into a state of despondency, when, in view of the approaching presidential election, it was suggested that we vote upon the subject ourselves. The idea was approved by most of our number, as it was also by the Rebels; for they wished to get an expression of the prevailing sentiment among us, that they might the better judge of the feeling that pervaded the people of the North. There were men among us from every State in the Union, and they naturally inferred that a vote in our camp would be an index of the vote at the North. Accordingly they urged the thing on, and promised to publish the result in the city papers, - though when they saw what the conclusion was, they hastily changed their minds, and no mention was made of our experimental election.

Many warm and even violent discussions had taken place for a number of days among the prisoners, and political spirit ran so high that they could not wait till election day. The vote was taken by States at the quarters of the senior ofticer of each State, and the results sent in to the general office. Written ballots were used, which were handed to the officer, and by him deposited in an old meal-bag, which served as a ballot-box. A bulletin-board and telegraph-office were established, and sham telegrams were published from the different States.

I cast my vote for Abraham Lincoln, as did my messmates, Hampton and Richardson, deeply regretting that it was my misfortune to be denied the privilege of doing so where it might be of some service. At six o'clock P s. the counting was finished, the result 
being ten hundred and twenty-four votes for Lincoln, and one hundred and forty-three for McClellan.

This was the expression of feeling and opinion among men who had been deprived of all the common comforts of life, half starved, with nothing but dirty rags hanging to their emaciated limbs to protect their bodies from the cold, wasting away by hunger and exposure, yet would not favor a peace degrading to their country's honor.

Cheer upon cheer arose from the prisoners and resounded through our prison yard, upon the announcement, making the McClellanites, who had been very confident of the success of their candidate, look crest-fallen and disappointed.

The Confederates understood the significance of the re-election of Mr. Lincoln full well. They knew it would be impossible to free themselves from the serpent into whose coils they had been drawn; but that they must fight for a cause that originated in sin, that was nurtured in iniquity, and that must perish in infarmy and disgrace.

The Rebel officers had continually misrepresented the Federal administration to the prisoners; and as we had no means by which to refute the arguments of these wily secessionists, except the firm confidence in our government, our souls were filled with joy and gladness by this favorable result of our impromptu election.

"The song of war shall echo through the mountains Till not one hateful link remains

Of slavery's lingering chains;

Till not one tyrant treads our plains,

Nor traitor lips pollute our fountains." 
Octsler 18.-Our camp was to-day thrown into a state of wild excitement, owing to the escape of three prisoners, who ran the guard and made towards "God's country." Several shots were fired at them as they passed the outer line, but without doing them any iujury, and they passed out in safety. The entire guard was aroused. The men flew to arms, the artillerymen to their guns. The Rebel officers, calling loudly to the guard to fall in, could be distinctly heard at my quarters, making me tremble for the fate of the brave men who, risking life, were trying to make their escape from this den of misery. After the occurrence of this affair, our guard was doubled, and orders given to the sentinels to shoot down every prisoner who should in any manner approach the "dead-line." This action on the part of the Confederates did not, however, intimidate us in the least; for we well knew, if compelled to remain there, in the condition we were then in, that death would surely overtake us; and to die in the attempt to free ourselves from the grasp of heartless tyrants would be no worse than starvation.

My plan for escape was not in the least disconcerted by this movement of the Rebels; on the contrary, my determination to be free was more fixed in my mind, and I continued the preparations for a leave-taking of Columbia and the hated Prison Pen, "Camp Sorghum."

After two days had passed, and no tidings were received from our friends, we began to feel that they must have escaped the vigilance of Rebel search. There was general rejoicing at their escape, and we 
worked ourselves into a state of fererish excitement over their success in passing the "dead-line." Our physical debility rendered us more intensely susceptible to excitement, and yet there is something about watching the progress of an escape from prison that will excite the most unimpassioned.

We looked upon their success as an index of what our own might be, should we make a similar attempt. And beside this, I trust we had higher motives to awaken interest. Although often reprehensibly selfish in matters that did not materially affect their lives and safety, our soldiers could still rejoice as thoroughly at the successful escape of a fellow-prisoner as though the good fortune had been their own. Many prayers were offered that a kind Providence would guide them safely through darkness and doubt to the Federal lines, and the most enthusiastic expressions of joy were manifested by all who had strength to rejoice.

The jubilation was undoubtedly somewhat quickened by the satisfaction it afforded us to know that the Rebel guards had been out-witted, and that Yankees could make their way through the heart of the Confederacy without being recaptured.

But our gratulations were brought to a melancholy sequel. It seemed that for every prisoner who escaped to safety, some comrade must be sacrificed of those who remained. There came, in the midst of our rejoicings, the sad and whispered intelligence, a prismer shot.

Lieutenant Young, of the Fourth Pennsylvania Cavalry, was shot down in cold blood, by one of the 
sentinels, while conversing with some fellow-officers, near a small fire. He only survived the shot a few moments. This occurred about ten o'clock on the evening of October twentieth.

No reason for this atrocity was apparent, and none was offered by our guards. It was another added to the already long list of cruel, heartless murders perpetrated in southern prisons. We were overcome with grief at the report, for Lieutenant Young was a brave man, a fine officer, a pleasant companion, and withal, had for a long time been a suffering friend.

Thus another noble spirit was ushered into the presence of its Maker, sent thither by the brutal hand of a murderer.

Were they men, and suffer such conduct? had they been taught the principles of love and justice, which are given to all in the great Book of Books? had they any sense of humanity in their bosoms? No, the foul fiend of darkness possessed and influenced their thoughts. Not satisfied with depriving men of the necessary food to sustain life, they shot down our defenceless comrades like dogs, without a shudder at the heinousness of the crime.

How long, oh God! how long will such fearful atrocities be allowed?

\section{LONG LIVE THE DUTCHMAN.}

A German captain was sent by the authorities, not long since, to take command of the prison. He was a pompous individual, and did things generally on the "spread-eagle" style.

As soon as he arrived, we were ordered into line to listen to a speech from the new commandant. 
Everything was conducted with accurate regard to military precision, and just at the right moment our Teutonic orator stepped forward, and delirered the following oration :-

"Shentlemens,-I comes to take command of you. I've been a brisoner mein selif. Your peoples treats me like shentlemens,-I treats you like shentlemens. Break ranks! March!!"

There was a general burst of laughter anong the prisoners, and cries of "Long live the Dutchman." A few days after he got drunk and was remored, and thus our hopes of making game of the Dutchman came to an unseemly end.

From the time we left Charleston the weather had been exceedingly cold and disagreeable, and no tongue can tell or pen describe the sufferings of the brave men confined there. The want of clothing made their bodies more susceptible to cold, and many were dying daily of diseases contracted from exposure to the sun and storm, and from a constant diet of coarse and unwholesome food.

\section{THIOLGIITS OF IIOME.}

Under such circumstances it was our custom to lie lown after taking our night's meal, not to sleep, but to talk over the incidents of our boyhood days, and the erents of our lives. Thoughts of home, and the friends gathered around loved tiresides, came crowding upon us; memory dwelt with clinging interest on scenes that might nerer be repeated; inagination feasted herself on pictures that might never prove a reality, and thus the long night was wearied through until the stars were growing dim in the light of ap- 
proaching day, when we sought that rest which our exhausted systems so much needed.

There were but few persons among us who had ever been compelled to suffer such privations and hardships. Most of them, before entering the army had been clerks behind the counter, students a. school, or well-to-do mechanics. Some were soldiers by profession, and many were sons of wealthy men, who had never known anything but pleasure, and had always taken life easy. But all, through the common impulses of their natures, and the patriotism ever burning in the loyal American heart, had offered their services to their bleeding and distracted country, to assist in subduing the element of discontent at the South, and the foulest and most unwarrantable rebellion against just and proper authority, ever known within the annals of time.

As to their fate, many were thoughtless and indifferent, some were distrustful of our Government and its intentions to liberate them; but few were without hope of approaching succor, and depending upon the mercies of an all-wise and overruling Providence, we made the best of our miserable condition.

I did not intend to remain in "durance vile" a great while longer; but upon the first favorable opportunity to take my flight, with some one or two of my friends, if they chose to go with me; if not, I should make the effort alone. I did not think any of my companions would refuse an offer to accompany me, if I should propose a plan which presented any chances of success. I kept my own counsel, however, and when the time shonld arrive, I would cautiously make 
my intentions known to those I wished to have accompany me, and then set out together. As the days came and went, our sufferings increased.

The season being far adranced, the cold night air chilled us through, and the stars, from their lofty stations in the hearens shone upon us clear and cold, while the moon reflected its pale, silvery light upon our palid faces, making us look doubly haggard and ghost-like.

\section{TAKING PAROLES.}

The prison authorities adopted a rule of allowing a certain number each day to pass outside the prison limits, for the purpose of backing in such quantities of wood as we could carry. This privilege was granted to such as would give their paroles not to attempt an escape.

The following was the nature of the parole issued:

$$
\begin{gathered}
\text { Confenerate States Militare Prison, } \\
\text { Colcmbia, S. C., October - } 1864 .
\end{gathered}
$$

$\mathrm{I},-$ - prisoner of war, coufined near the'city of Columbia, S. C., Confederate States of America, do pledge iny parole, as a military man, and a man of honor, that I will not attempt to escape from the prison authorities, nor pass beyond the prison limits more than three quarters of a mile, and that at the expiration of the time named in the parole, I will return promptly to the adjutant's office and have the same revoked.

It is understood by me that this parole is voluntary on my part, and that it is given with a riew to securing pririleges which cannot otherwise be obtained.

(Signed)

Many accepted the offer, and went out to bring in what they could pick up in the shape of dry twigs, broken branches of trees and bark. It was a sad 
sight to see us filing along under guard, picking up what we could carry, and returning with our loads upon our backs.

Some of the men were so weak that they became as helpless as a child, and had to be carried back to camp in a state of utter exhaustion and insensibility. In trying to help themselves, they overtaxed their remaining strength, which brought on fevers and delirium, from the effects of which many died.

I profited, however, by the arrangement; for not only a sufficient quantity of wood was procured to last me and my mess two days, but in carefully examining the plan of our pen, and the system by which it was guarded, I obtained and added to my small store of knowledge much valuable information concerning the surrounding country. All of which, at some future day, then not far distant, would be made serviceable.

I was not by any means the only one to profit by these explorations. Others, as much on the alert as myself for adventure, conceired plans whereby they effected an escape; but unfortunately, after a few days had passed, were generally recaptured and thrown into county jails.

They had the satisfaction, during their absence, of getting some corn-bread and bacon of the faithful negroes, out of which they could make at least a few good meals; and this alone was enough to compensate for the attempt.

Every soldier knows that the times when he succeeded in getting "good square meals," as they were called, were epochs in his military history, - so mucb we men the slaves of their wants. 
My old shoes being badly worn, I took them to the "camp cobbler" to be repaired. He gare me no encomragement, but said they were past redemp. tion, and could not be improred.

How could I trarel barefoot through the hot burning sand of the highway, the stone-corered fields, or the deary swamps? I must hare some corering for $\mathrm{n}_{\mathrm{y}} \mathrm{y}$ feet, and at once set about preparing something myself.

By dint of good luck, I obtained the rim of an old worn-out regulation hat, from which I eut some inner soles, and by tying the outer sole to the uppers with a piece of cord, made them appear no worse, and added largely to their worth and ciurability; thus my feet were protected from the heat and cold.

In making an escape it is absolutely necessary that there be suitable protection for the feet, and eren under the most destitute circumstances all such contingencies had to be provided for.

During the last two weeks of my stay at Columbia the nights had become so cold that we did not think of lying down, but would walk around the camp for the purpose of keeping the blood in eirculation to prevent chilling.

When the sum rose in the noruing, and not till then, would we stretch ourselves on the ground to sleep, the heat from its rays warming us and keeping 11s. warmed while locked in the arms of Morpheus. We literally turned night into day and day into night. Those who have lired in northern latitules kuow how disagreeable it is to be so situated as to be obliged to exercise continually in order to keep from 
chilling. It may be endurable for a few hours, but one after a time becomes weary of it. But our lack of clothing was such that we had to be on the alert during the whole night,-and that night after night.

November 8, 1864. - This eventful day was one of intense excitement and anxiety with us, as it was to decide who should be our chief magistrate for the next four years. We felt satisfied that the election would result in retaining $\mathrm{Mr}$. Lincoln, our then respected President, in the chair which for the past four years he had filled with so much credit to himself and honor to the nation; and jet an almost certain election has its excitement, and the certainty cannot be an absolute certainty until the last vote is cast. We would rather have known the result than believed it.

EXCHANGE RUMORS.

We were also notified by the prison authorities that a general exchange of prisoners would take place on the twentieth. Captain Hatch, the Rebel commissioner of exchange, was there; and it was rumored about camp that a large portion of our number would be taken to Savannah immediately, causing great excitement. The "fresh fish," especially, were in excellent humor over what they styled glorious good news. The old prisoners were not inclined, however, to be very jubilant over the announcement, as they had many times before been duped and deseived by the practical infamy of the Confederates. And it was very well that we put no faith in such coose reports, for at this time, as on many other neca 
sions when such rumors were circulated, nothing official had been receired.

"Ifope comes again to the heart, long a stringer;

Orce more she sing; me her flattering strain;

But hush, gentle siren! for, ah! there's less d:nger

In still suffering on than in hoping aguin."

The Rebels always took advantage of the natural despondency following so much excitement, to endeavor to persnade the prisoners to believe that our government cared nothing for our sufferings, and would use every other means at their command to canse us to lose confidence in the Federal authorities and the commanding officers of our army. They miscrably failed, howerer, in their endearors to extinguish the fire of patrioti-m burning in our bosoms, by such contemptible mi-representations, and only added to the bitter hate in which we looked upon these vile traitors and inhuman wretches who guarded and starved us.

\section{CAUGHT BY HOLNDS.}

Many of the recently escaped prisoners were bronght back to us about these times, most of whom were caught by hounds. Lieutenant Parker was so lacerated that he died the next day after his capture. On the fourth inst., Lieutenant J. Clement, of the Fifteenth Kentucky Cavalry, was captured by a Rebel liring but a short distance from Chapel's Ferry, South Carolina. After he had surrendered the dogs rrere let loose on him; and thus he was so seriously injured as to be disabled for a long time. I should have made my escape on the fourth, had 


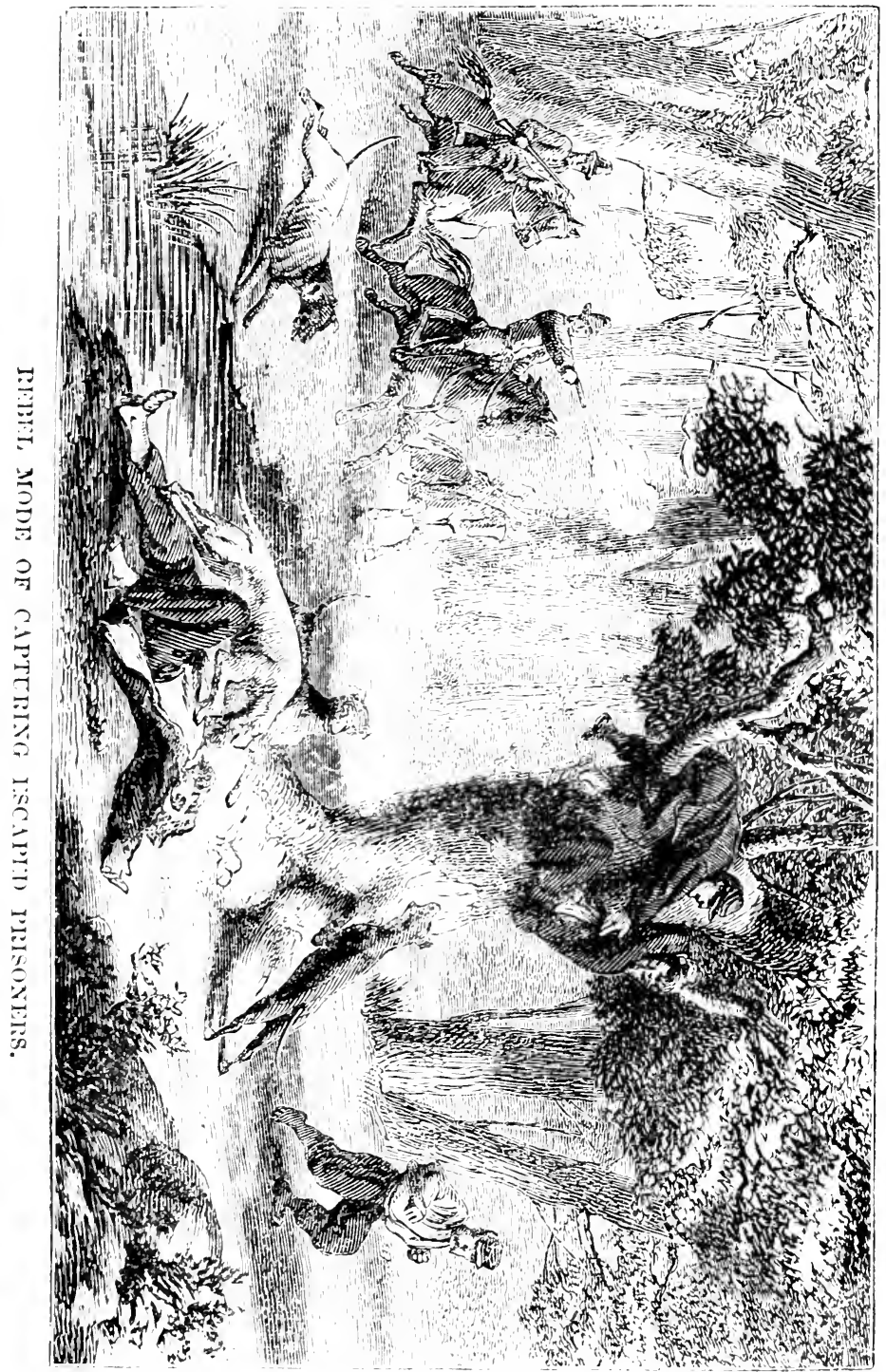



not my health been so delicate that I could not have walked out of camp, even had the road been clear I had been suffering very much from camp diseases, and was so weak as to be unable to walk without the aid of a friend.

Near the twelfth of November rumors reached us that General Sherman had left Atlanta, and was moving through Georgia in three columns. It was currently reported that he would occupy Augusta, Macon, and Savannah. The "great general's" movements were but little understood by the Rebels; they were considerably alarmed, and began concentrating their forces at Augusta.

\section{DRAWING MEAT RATIONS.}

About this time quite an amusing scene enlivened our camp. An old wild hog chanced to pass the guard line; and as soon as he came within range of the prisoners, a general advance was made and he was ours. But a few moments elapsed after his entrance among us before no traces of his carcass could be found. From four to five hundred half-starved men gave him a most hearty welcome. "He was a stranger and they took him in," in more senses than one. One seized a leg, another an ear, and another his tail; and as many as his dusky exterior would accommodate twisted their skinny fingers into his long, arrowy bristles, and closed their hands and eyes and teeth as if for a death-struggle. There was tumbling and tripping and pushing and yelling and swearing, while the Rebel guards, at a "parade rest,' were laughing heartily at the ridiculous scene. 
Every man clung to the part he first seized, and that part was to be his portion. Richardson was the first to seize a hind leg, and this leg he clung to through all the melée like grim death to his victim, and did not relinquish his hold until it was cut off and securely lodged in the mess kettle for supper.

Our guest was not "the fattest hog in Epicurus' sty," but we were in no condition to make a point of quality, and thankfully struggled for steaks that "would not fry themselves."

This was the first and only ration of meat issued to us while at Columbia, and this-no thanks to the Rebels-very foolishly issued itself.

It would have been useless for the prison authorities to try to deprive us of this well-earned booty, for in less than five minutes after the first salute it would hare been impossible to find enough of the grunting porker to grease a skillet.

"When the black hog was seen on a run through the camp

Each soldier forgot his starvation and cramp;-

The grunts of the hog and his running were vain--

His form will ne'er darken that camp-ground again."

The Tandering Poet of New Hampshire.

SHERMAN'S MARCII TO THE SEA.

A few days confirmed the rumors that had been floating with regard to Sherman's morements. It came to be generally understood that he was marching on Augusta, Nacon, and Savannah. These re. ports had the usial effects-of depressing the Rebels, and inspiring the prisoners with hope. Many attempts to escape were made at this time-with varying success. Sereral shots were fired into the pen by 
the sentinels, and one prisoner had his arm blown off in an attempt to run the guard.

On the twenty-third, Lieutenant George R. Barse, Fifth Michigan Cavalry, of whom previous mention has been made, escaped by strategy while the prisoners were passing out on parole after wood. The officer of the guard had taken position without the guardline, where he had a battalion of men in readiness to send to the woods with the paroled prisoners, allowing sereral to go at a time, and proportioning the number of guards to the size of the squad. As each party arrives near the "dead-line," one of the number manifests a desire to pass out, at the same time exhibiting a paper with signatures attached to a written parole. The officer of the guard then beckons to the sentinel to permit them to cross the line, when he takes their paroles and hands them to one of a certain number of armed men, who are detailed to act as their escort. Barse followed a squad that observed all this necessary formality; but the officer and guard were none too bright; and Lieutenant Barse went on, rejoicing no doubt at his good fortune, until he reached the woods, when he claimed that he was a hospital steward, and had nothing to do with the men, whom he had only chanced to walk out of camp with. Luckily, there was no one present to contradict his assertion, and, without further ceremony, he marched off at his pleasure.

Great excitement prevailed just now over Sherman's terrific march through Georgia, which was just beginning to develop itself. The Legislature removed to Macon, and Governor Brown issued a proclama. 
tion, ordering to the front every man capable of bearing arms.

Thanksgiving Day brought us much to be thankful for, to be sure, but little heart to enter into the celebration of such a day. There was great suffering in camp on account of the severity of the weather. We had heary frosts frequently, and many, having no blankets, were obliged to find warmth in exercise.

\section{CHOICE OF POSITION.}

Hampton, Richardson, and myself, possessed a small blanket each, but with eren these it was almost impossible to keep from freezing. We slept in the middle by turns, and this privilege with us was a matter of the gravest importance. So unpardonable was the offence of attempting to deprive one of his equal rights in this respect, that many quarrels originated from no other cause. In a case involving so much interest we did not trust to memory, but, on turning out in the morning, marked upon the ground the name of the individual who was to have the choice of position at night. This method was not resorted to until we found it to be our only safeguard against disputes. The one who slept in the middle was usually quite comfortable, although his sphere of operations was rather limited, for those on the outside naturally inclined to crawl away from the chilly flanks towards the centre. In this way we could get some sleep one night in three, if not drowned out by a rain storm.

After waiting our turn for more than three weeks, we at last succeeded in securing an old shovel, with 
which we dug a cave in the ground large enough to crawl into at night, and during storms.

There seemed no prospect of a general exchange, and the prisoners were determined to make the best of their miserable situation. So far as I was concerned, it was not my intention to spend a single night in this bear's den, if possible to effect an escape; and yet we always thought it worth our while to be prepared for the worst.

The greater part of the twenty-tifth was spent in digging, and we accomplished as much during that "long, weary day," as a first-class ditcher might have done in an hour. I became tired of it, and fully resolved to make my escape on the twenty-sixth. Saw friend Lemon, and proposed to him a plan by which we could relieve "Camp Sorghum" from any further care of our persons. We could not think of being longer dependent on the bounty of our enemies, and determined to strive for some advantage of situation which would enable us to return their compliments.

\section{PLAN OF ESCAPE.}

It was customary to extend the guard-line in the morning, for the purpose of allowing the prisoners to pick up wood on a piece of timbered land just opposite camp; and it was our intention to take a shovel, when permitted to pass to the woods, and make a hole in the ground large enough to receire our two skeletons, and then have our friends cover us with brush and leaves. Thus concealed, we hoped to be left without camp when the guard should be withdrawn. Should we succeed in escaping the vigilance 
of the sentinels, it was our purpose to strike for Augusta, Georgia, feeling assured that General Sher man would soon occupy that place. Many preferred to strike for Knoxville, Tennessee, considering that the safer, though it was much the longer route to our lines. Our course would incur more risk, but the sooner bring us within the Federal camp. Indulging these expectations, we lay down to rest.

On the morning of the twenty-sixth Hampton and Richardson asked if we should continue work on our "mud burrow." I replied that I should dig no more holes in South Carolina; that they need make no arrangements in their mud house for me, as I did not propose to have any futher use for subterranean carerns. They looked at each other with a knowing smile, doubtless thinking a temporary disgust had come over me, which would soon wear away, and I would again return to my quarters. Under the circumstances, I am disposed to pardon them.

Lemon and myself kept a careful lookont, anxiously waiting for the guard to be extended out into the woods. But the morning was cold and rainy, and the guard not caring to leare their snug tents along the line of the encampment, we were left without fires.

Thus our hopes were again blasted, and nothing was left us but to make a bold strike, and pass the guards by a plentiful cxhibition of "brass." How this was accomplished will be set forth in the next chapter. 


\title{
CHAPTER XIII.
}

THE ESCAPE FROM COLUMBIA.*

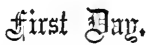 \\ Lexington Court House Road, Near Columial, S. C.,
Saturday, November 26,1864 .
}

WHILE taking a stroll through "Camp Sorghum " in the morning, for the purpose of finding a weak point in the guard-line, I observed one of the guards to be a stupid-looking fellow, and resolved to test his abilities before he should be relieved perhaps by one of brighter appearance. Accordingly I hastened in pursuit of Lieutenant M. W. Lemon, of the Fourteenth New York Heary Artillery, a man of courage and enterprise, with whom I had decided to escape. I only told him to meet me at a certain point, and be ready to leave the pen, in three minutes.

No time was lost in packing, or checking our baggage to any given point; and we also deemed it unnecessary to bid our friends good-by, or to thank the proprietors for hospitalities received.

In an incredibly short time we were at the specified place of departure, and soon were passing the "dead-line," as if that point possessed no further

* Written during the escape, while in the swamps and cotton gins of South Carolina and Georgia, where we were often secret. ly fed by the ever-faithful negroes. 
terror or interest to us, when the aforementioned worthy brought his musket to bear upon me with an uncomfortable precision, at the same time ordering a halt.

"Where are you going, Yanks?" he demanded; but with an air of offended dignity, I only said, "Do you halt paroled prisoners here?" His meek "No Sir," was not yet lost in the distance, when I boldly crossed the dreaded line, adding, "Then let the gentleman in the rear follow me;" and so we passed, while the brilliant sentinel murmured, "All right."

And right it was; for now we were free, breathing the fresh air, untainted by the breath of hundreds of famishing, diseased, and dying men.

Outside of the pen were numbers of paroled prisoners gathering wood, and Rebel guards strolling about. We at once commenced discussing the most favorable locality for obtaining brush with which to cover our "mud-burrow," and thus conversing about our domestic affairs, it was not long before we were well into the woods, - the guards thinking, no doubt, if they thought at all, that we had a right to be out with the others on parole. Once well beyond the sight of gray-coated sentine?s, we put our long untried strength to a test and placed a few miles between us and Camp Sorghum hurriedly. There was not very much of dignity in our departure, to be sure,- - not to say grace or beauty,-and it may be that there was something a little suspicious in a certain looking orer the shoulder, that might have been observed as we sloped through bushes and leaped orer logs. Quite likely horse thieres, when thwarted in their purposes have propel- 


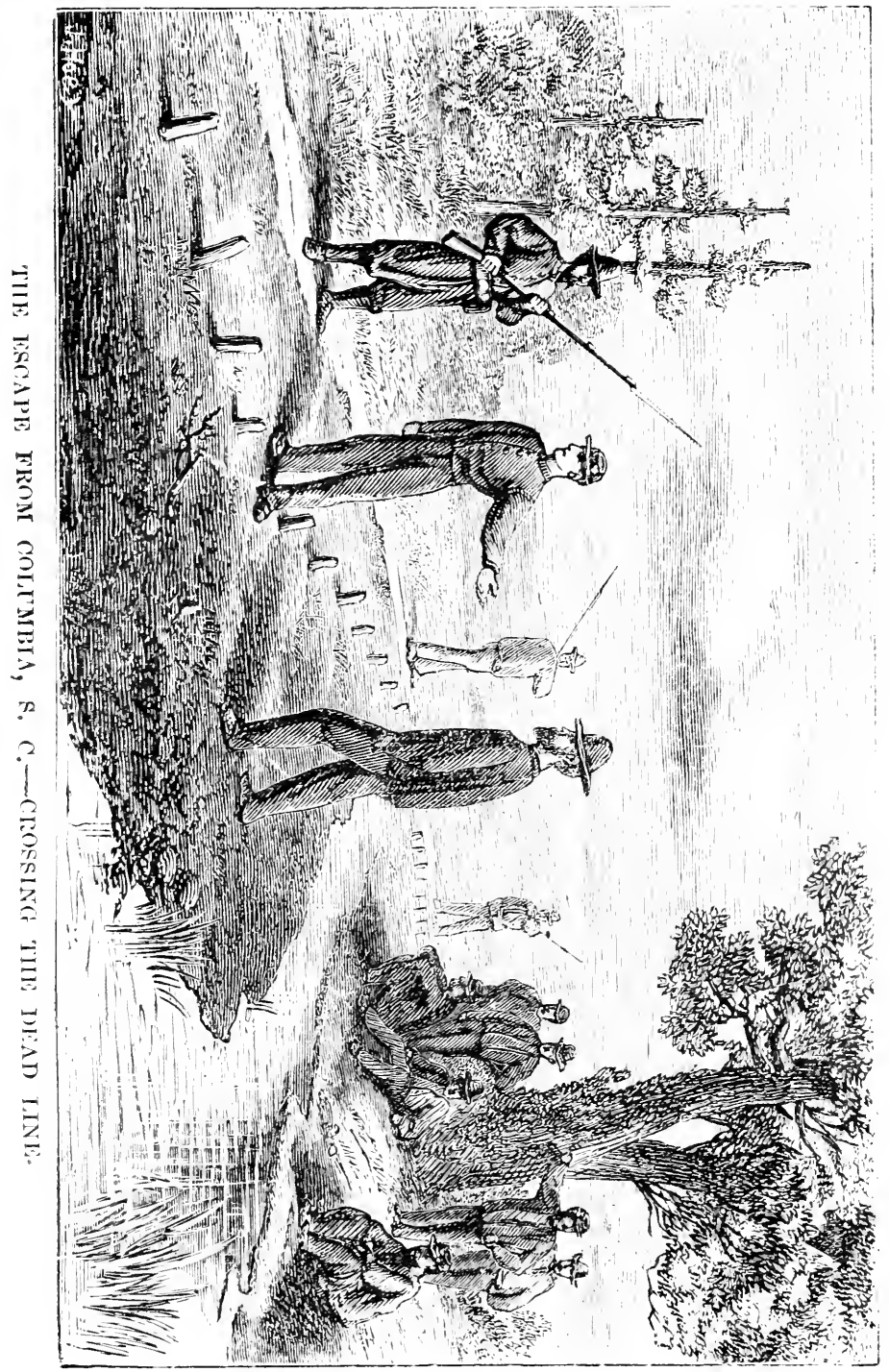



led themselves from the scenes of their embarrass. ments in a manner not remarkably dissimilar. It may be that not very high-toned curs, in getting away from the back-doors of butcher shops would find it convenient to imitate us rather closely;-and yet there was something in this style of locomotion that seemed peculiarly adapted to our circumstances, and we fell into it instinctively, as it were.

We have never, as yet, to any great extent, had occasion to regret our haste and want of dignity.

As soon as we had put sufficient distance between ourselves and the Prison Pen to make leisure more compatible with safety, we proceeded more slowly.

The country, ontside of cities and villages, at the South, is always so sparsely settled that, once on the road, and no hounds upon the track, one can readily find places of concealinent. Of course, it was policy for a time to make ourselves comparatively scarce. We made a little progress, however, following ravines and concealed places, and always avoiding roads and openings.

Several times we encountered white people, but succeeded in evading them. After sauntering along until about two o'clock, we lay down to rest a while, where we remained snugly concealed in thick bushes until twilight, and, though weary and heary with sleep, we found but little repose, on account of the excitement of our situation. It seemed as though every crackling of twigs or rustling of leaves heralded the approach of pursuers, and the sighing of the breze in the tall pines was the whistling for a pack of blood-hounds. 
With the fall of night we were up and doing, and soon struck the road leading to Lexington Court House. Following this for some little time we heard voices behind us, and slackened our pace to discover whether they were negroes or white men. It is sometimes difticult to determine, as their manner of conversation is precisely alike in many portions of the South.

When they were within ten or fifteen feet of us, partly turning, I said, "A pleasant erening, gentlemen."

This was intended to be equally applicable to both whites and negroes, but the answer was equally indefinite. One of them merely remarked, "Indeed it is," and said no more.

We were rather led to believe they were white men, and so quickened our step and left them somewhat behind.

As the distance increased, their conversation com. menced again, and we heard one of them say, "I reckon dey's Yankees." Another replied, "I hope to God dey is."

This satisfied us that they were negroes, and we turned round and met them. I asked, in a low voice, "Do you know who I am?"

"I reckon I dun no ye, Massa."

"Have you ever seen a Yankee?"

"Lor' bless ye, Massa. I've seed right smart of a heap ob 'em down to Columby."

"Do we look like Yankees?"

"Can't very well tell in de night-time; but I s'pect you talk like 'em." 
"Well, my good fellow, we are Yankees, just escaped from Columbia. Can't you do something for us?"

"Ob corse, I'll do all I can for you 'uns. I'se no nigger if I wouldn't 'sist de Yankees."

Being satisfied that they were entirely trustworthy, we unfolded our plans to them. There were three of them. They had been at Columbia, working on a new prison stockade, which the Rebels were building for the reception of Federal prisoners. Judging, however, that Sherman's movements might make this labor useless, they had stopped work, and sent the negroes to their masters. These three fellows were the "property" of a Mr. Steadman, whose plantation is situated some twenty-fire miles southwest of Columbia, on the road to Augusta. Thus we were traveling in the same direction.

We stepped aside in the bushes to arrange a plan of procedure, and after discussion of the subject, one of their number, "Ben Steadman," agreed to becorne

\section{OUR GUIDE,}

while the other two were to travel by themselves. This proved a wise arrangement in the end, for the fact that there were only three of us together probably sared us from recapture, and "Ben" from detection and punishment.

Our guide decided to leave the main road, and take a shorter cut to his master's plantation. It was arranged that "Ben" should walk in advance some little distance, and if he met any white men, give us warning by a peculiar kind of cough-while we, on 
the other hand, were to give him notice of danger in a similar manner.

After a tramp of two or three hours we struck a "blind road," and, being assured by our guide that it was never frequented by white men after dark, disregarded our first precaution, and walked carelessly along, chatting vigorously with "Ben" upon those subjects which most interested us. We had not proceeded far, however, before we were reminded of the necessity of moving more cautiously. Our reminder was none other than

\section{A REBEL PICKET}

of eight men, a little to the left of the road. Fortunately for us but one of the number was awake. Supposing that we were negroes, he allowed us to approach until we were nearly opposite the picket before the challenge, "Who comes there?" was given, and our guide answered, "Friends." Lemon and myself could not see that anything would be gained by a recapture, and so we fled down the road at the top of our speed. This was the first test of our fleetness since leaving the Prison Pen, and in justice to Lemon, I am compelled to confess myself badly beaten. I could not help saying, "Go in, Lemon," nor avoid a suppressed laugh while straining every nerve to overtake my rival in the race.

Meanwhile "Ben" was making a good story of it, telling the picket that the other two darkies got scared and ran away, adding, "I dun no what makes dem niggers run so."

His story being corroborated by those who had scen him leave the stockade with two other negroes, 
he was soon set at liberty, ready to do another good turn when called for.

Expecting to be pursued, we soon concealed our. selves behind a $\log$ near the roadside. After a little a detachment of the picket passed by, escorting "Ben" to the reserve; he, in the meantime, narrating the adventures of the night, and denouncing "dem two cowardly niggers" in good round terms.

After they had passed, we followed them cautiously in the deep sand, until they came to a squad of men sleeping and watching around a large fire. Not being able to flank them, on account of swamps which lay on either side of the road, we halted and slept near them till morning.

While looking for a place of concealment, Lemon and myself became separated, and not daring to speak, crawled around nearly an hour before we found each other. We had eaten nothing save a small piece of corn-bread since leaving Columbia, and had not dared to present ourselves before any habitation; we hoped, however, to break our long fast as soon as possible.

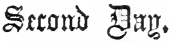

\section{Near Barntell Cotrt Hotse, Sunday, November $27 . \quad\}$}

Soon after daylight the picket, near which we had been sleeping, scattered in every direction, and went to their homes. They were not regular soldiers, but bushwhackers, who were on their plantations during the day, and met at night to patrol and picket the highways. 
This left the coast elear, and, breakfastless, we began to pick our way through the swamp which lay before us. Passing through it, we came into a rolling, wooded country, and pushed on, taking the road for a guide, but not daring to come nearer to it than about a quarter of a mile. We found nothing to eat but a few blueberries, not the best trareling diet in the world, but thankfully receired under the circumstances. A'bout nine o'clock 4 . y. we crossed the road with a view to putting possible pursuers off the track. At eleren o'clock we came to a clearing, and made our way to a barn near by; but seeing a planter standing by a fence across the field, we hastily retraced our steps and got into the woods again. Shortly after, we came to another open field, which we crossed successfully.

About four $0^{\circ}$ clock in the afternoon we came to a large plantation, and approaching within thirty or forty rods of the building, we lay concealed in the bushes. Here we tried to attract the attention of negroes, but were unsuccessful. While snugly ensconced behind a large fallen tree, a white roman and sereral small children came riding down the road on a mule, and passed within a few feet of us; but we hugged the ground closely, and were not obserred.

\section{OLR NUTE GUIDE.}

When night came, we cautiously crept on our way along the side of the road, and about nine o'clock came to the junction of four roads, where we fortunately found a friend in an old guide-board.

Jumping on my companion's shoulders, I was en 
abled by the light of the moon to read the direction and decide upon the course to be pursued. We then pushed on our way at a rapid pace until about two o'clock A. M., when we lay down in the bushes near the roadside to sleep.

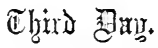

Near Black Creek, S. C.,
Monday, November 28.

We were awakened just before daybreak by the villainous barking of a dog, and found ourselves but a few rods from the plantation of Alexander Taylor. The dog had attracted the attention of the people towards our hiding-place, and as soon as a move was made, we were observed. Running, I knew, would be useless, as I could see the planter's wife looking at us.

My companion preferred remaining at a safe distance from his dogship, while I approached the ladies, who were already assembled near; and after learning; there were no white men on the plantation, I frankly stated my case, and appealed to their sympathies for something to eat.. They were at first unwilling to grant me any assistance. Mrs. Taylor said that her husband was in the Confederate army, that her heart was with the southern people, and further, that she thought it wrong for her to aid a Yankee in making his escape. I then addressed to her a brief speech, resembling, in many respects, the story of the old unfortunate hero Ulysses to the goddess Calypso, in which I recounted, in pitiful terms, my misfortunes, and my disappointment should I fail of reaching \{reneral Sherman's lines. 
I made no gestures, struck no attitudes, and used none of the enticements of rhetoric, but simply made a direct appeal to her benevolent feelings; and this, aided by my forlorn and destitute condition, won her sympathies. The kind-hearted lady remarked that she "would see what could be done for us," and, going into the house, she returned with a generous supply of corn-bread, bacon, and sweet potatoes.

After receiving a promise from the ladies that they would not betray us, I promised Mrs. Taylor that if ever her husband came into Yankee hands, and it was in my power, I would see that no harm befell him; and this promise I would hare kept, eren at the expense of my own life. The rations were soon hurried into my haversack, and after again thanking my benefactress for her kindness, I returned to my companion, when we hastened off to a thicket in the forest, built a pine-knot fire, roasted our potatoes, and made a "royal breakfast." Oh, ye who sleep on beds of down, in your curtained chambers, and rise at your leisure to feast upon the good things provided, smile not when I say that you never knew the luxury of a night of rest, nor the sweets of a meal seasoned by hunger, with the grateful remembrance that it was provided by woman's kindly heart, which, wherever it may beat, sooner or later responds to the tale of misfortune, which, alas! is too often told by suffering humanity.

A bath in a stream near by, with the washing of our stockings, completed the toilet of the morning, and we were glad to seek rest, being weary, weak, and sore, the result of violent walking. 
After resting all day, we roasted more potatoes at aight, and putting our feet to the smoldering embers, again lay down to sleep. It was our purpose to awaken at eleven o'clock and pursue our journey, but we were so much exhausted by walking and exposure, that sleep entirely overpowered us, and the night was far spent before we again awoke. We were soon on our way, however, endeavoring to redeem lost time.

$$
\text { 起ourly 录ar. }
$$

$$
\left.\begin{array}{r}
\text { Near the North Edisto Riter, S. C., } \\
\text { Tuesday, November 29. }
\end{array}\right\}
$$

We reached Black Creek this morning just before daybreak, and, while crossing the bridge over said stream, met a negro on his way to work, who gladly turned back and conducted us to a hut for safe-keeping during the day.

This hut, familiarly known throughout the neighborhood as

\section{AUNT KATY's,}

was the general rendezvous of all in want of assistance. The good old soul cheerfully roused from her morning slumbers, when she learned that Yankees were at the door awaiting her attention. We were welcomed with a hearty "God bless ye, Massa," and, while she made preparations for our "creature comforts," a little boy was sent to ask in her dusky neighbors, that they might "rejoice with her" ove1 the good fortune of having an opportunity to aid friends in escaping from a common enemy. In an incredibly short space of time the entire colored population of the plantation were assembled. 
To exhibit their deep religious interest in our welfare, a prayer-meeting was improvised for our especial benefit, and they conducted it in a manner both creditable to themselres and amusing as well as interesting to us. The burden of their petitions was, that all the prisoners held by the Rebels might make a general exodus and reach the Yankee lines in safety; that we, in particular, might succeed in making our escape; that our armies might speedily conquer the whole of Secessia, liberate the slaves, and take possession of the land.

\section{"UNCLE ZEB'S PRAYER"}

was perhaps the most characteristic, and once heard, could never be forgotten. He appeared to be a ruling spirit in the party, and by common consent, led off as follows :

"O Lor' God A'mighty! we is your chil'en, and 'spects you to hear us widout delay,-cause we all is in right smart ob a hurry. Dese yer gemmen has rund away from de seceshers and wants to git back to de Norf. Dey hasn't got time for to wait. Ef it is 'kording to de des'nation ob great Heben to help 'em, it 'll be 'bout necessary for de help to come right soon.

"De hounds and de Rebels is on dar track. Take de smell out ob de dog's noses, O Lor'! and let 'Gypshun darkness come down ober de eyesights ob de Rebels. Confoun' 'em, O Lor'! dey is cruel, and makes haste to shed blood. Dey has long 'pressed de black man, and groun' him in de dust, 
and now I reck'n dey 'spects dat dey am agwine to serve de Yankees in de same way.

"'Sist dese gemmen in time ob trouble, and lift 'em fru all danger on to de udder side ob Jordan dryshod.

"And raise de radiance ob your face on all de Yankees what's shut up in de Souf. Send some Moses, O Lor'! to guide 'em fru de Red Sea ob 'flicshun into de promised land.

"Send Mr. Sherman's company, sweepin' down fru dese yer parts to scare de Rebels till dey flee like de Midians, and slew darselres to sabe dar lives.

"Let a little de best ob Heben's best judgments res' on Massa Lincum, - and may de year ob Jub'lee come sure.

"O Lor'! bless de gin'rals ob de Norf-O Lor"! bless de kunnels-O Lor'! bless de brigerdeers--O Lor'! bless de capt'ins-O Lor'! bless de Yankees right smart. O Lor'! Eberlastin'. Amen."

This prayer, offered in a full and fervent voice, seemed to cover our case exactly, and we could join in the "Amen" with heartfelt derotion. We may never know how much negro prayers hare aided the cause of the Union, and availed in behalf of our escaping prisoners. Other prayers followed "Uncle Zeb's," and a "refreshing season" was the result.

As faith without works amounts to nothing, their next step was to make arrangements for our future.

It was now near daylight, and they advised that we remain within the hut during the day, assuring us that "no white folks nebber come near Aunt Katy's -so don't be 'fraid, Massa." 
Erery one offered to do something for us. One could make some hoe cakes, another could bring some bacon, another had some fresh pork, that had just been killed on the plantation, and still another "reckoned he might git to find a dead chicken somewhar."

\section{EXCOURAGING PROSPECTS.}

"Uncle Zeb" was a sort of unirersal genius, and learning that we needed a knife to cut our rations and dispose of any small game we might chance to meet with, volunteered to make us one. Another would bring us a bag to serre as a haversack. Others still would provide food and articles of clothing. After making these promises they dispersed to their work, assuring lis that they would return in the erening.

Thus our whereabouts was known to about thirty negroes, young and old; and I renture that we were as safe from betrayal as though they had been our own soldiers. The talent of the negro for concealment is something wonderful. Their whole history as a race has compelled them to it, and they hare been ready scholars. They can often make white men believe a downright falsehood, when they cannot persuade them to believe the truth. A shrewd lawyer, with his suspicions fully aroused, might have puzzled even a ten-year-old boy in rain, to get any information of our situation.

When "Aunt Katy" sent her little boy, about eight years of age, to notify the colored people of our arrival, we were apprehensire that it might not be safe to trust so young a lad, but the old lady assured us 
that we need have no fears, as the " chile know'd what he's 'bout." She then told us that only a short time before, when some escaped prisoners were concealed in her hut, the planter had had suspicions of the fact, and riding by, had asked the little boy if there were not Yankees in the house, when the young rascal, giving a start, rolled his eyes in the direction of the hut, with a woebegone look, and asked quickly, "Yankees in dar!" and then added, with a shudder" of fear, "Gor A'mighty, Massa, ef dar was, you wouldn't ketch dis darky yer, no how. Dem Yankees got horns on, Massa, and I'se 'fraid of 'um. Ef I seed one of 'um comin' for me, I'd die, shoore." The master rode on, doubtless well pleased with the manner in which his stories about Yankees had been treasured up.

It is an established fact that it would have been impossible for our men, held as prisoners of war in the South, to make an escape without the aid of negroes, and it would hare been nearly as impossible, had they been strictly truthful in all cases.

Evening brought the morning party again to "Aunt Katy's." "Uncle Zeb" had manufactured the knife, in good earnest. He had taken the largest file the plantation afforded, and hammered it into a blade nearly two feet long. To this he had attached a handle some eight inches in length, and two in diameter. With this young sword, he stalked into the room with an air of triumphant satisfaction. His ideas of the use to which it could be put were somewhat dif. ferent from ours, as his presentation speech will serve to show. 
"Here, gemmen, is yer knife. I reck'n yer'll find it bery useful in trabels. Yer can cut yer hoe cake wid it, and ef yer happens to be on de trail ob a pig yer can chop his head off afore he gits to give a squeal" (flourishing the knife).

"And likewise, gemmen, ef ye comes in a bery tight place, dis jer might cut a Buckrey's (Rebel's) head off. I'se grounded it right sharp for ye, (feeling of the edge), to have it ready for quick work."

This speech was delirered with all the dignity of a Senator, and it never occurred to him that his labor might be thrown amaj.

Just here, another brought us the bag we had bargained for. It was an old tow-string sack, and would hold two bushels or more. We could hardly repress langhter at these generous attempts to meet our demands, but took them with us as relics of our experience.*

One of their number, a friend of "Ben Steadman," by the way, offered to accompany us as guide. "Ben," he said, was taken prisoner, as before related; and upon examination, told the plausible story aforementioned, that Lemon and myself were two foolish darkies who were scared at the pickets. The latter part of the narrative being strictly true, it was hardly necessary for us to rectify the former.

The Steadman plantation was only three miles away, and "Ben" was afterwards brought to our place of concealment by his colored friend from Black Creek, and kindly offered his serrices for the occasion.

* Lemon had the knife at the time of our recapture. 
We told him we were anxious to learn General Sherman's movements, and would like a paper. He insisted upon our going to his hut, although we much preferred the swamp; but were at last prevailed upon to accompany him. Arriving there, we were politely introduced to Mrs. Steadman and family. They viewed a live Yankee with not a little curiosity; after this, "Ben" instructed his daughter to go into the house of her mistress and snatch a paper at the earliest opportunity. She soon came running back with the $A u$ gusta Constitutionalist, published that morning. The celerity with which the blacks carry off a desired article, or accomplish a mission for a friend, is truly astonishing; and no watchfulness on the part of their master can stay a project when once the heart is in it.

\section{CROSSING THE NORTH EDISTO.}

Having possessed ourselves of the contents of the paper, we struck the road and crossed the North Edisto at ten o'clock P. Mr.

The water was over the bridge in many places; so we were compelled to ford the stream.

It was our intention to reach and cross the South Edisto before morning, but having become confused by the intersection of "blind roads," and having lost our way, we were obliged to halt for the night in a pine grore, we knew not where.

\section{dffitly 包ag.}

$\left.\begin{array}{l}\text { Near the South Edisto Rirer, S. C.., } \\ \text { Wednesday, November } 30 .\end{array}\right\}$

We breakfasted this morning on hoe-cake and pindars, popularly known as peanuts at the North. 
They were among the provisions given us at "Aunt Katy's," from whose more than hospitalle hurel we had gone laden not only with eatables, but also with good wishes, prayers, and blessings, which we cannot soon forget or lose.

\section{FINDING OLR BEARINGS.}

We were, at this point of our journey, more or less puzzled, having lost our latitude and longitude, and being also without a guide, "Ben" haring left us some time before night. After following roads last evening for several hours, we were brought to a standstill at the edge of a swamp.

There were no stars plainly visible, and we had not yet learned to take the moon for a guide. Besides, the hearenly bodies in southern latitudes have so different an appearance from those seen at the North, that we were for some time after the eseape in constant doubt as to the points of the compass. I remember it caused me great grief to find that the north star was much nearer the horizon, and seemed to have lost that prominenee which is given to it in high latitudes, where it is a guide, standing far above tree-top and mountain. Yet I soon came to hail it as a faithful sentinel "that guards the fixed light of the aniverse, and bids the North forever know its place."

After moving to the pine grove mentioned in the last chapter, which was only a short distance from the swamp that stopped our progress, we slept till about ten o'clock $\Lambda$. sr. Thinking it necessary to get our bearings by daylight, which we could not do, if the sun did not shine to assist us, by means of the streams, 
which, in this part of the country, we knew flowed in a southeasterly direction; also by the chains of hills, which in every country have the same general direction as the streams. We were assisted not a little by the moss on the trunks of trees, which always hangs in heariest masses on the north side. These signs by day, and the heavenly orbs by night, supplied the place of maps and magnetic needles.

We were obliged to skulk along during the whole day, passing many plantations, and exciting the ire of an array of contemptible curs, whose only business and only pleasure was to howl at civil people who asked no recognition.

Good luck favored us somewhat, for we were in sight of buildings several times during the day. But dangers and annoyances made us irritable. We could scarcely agree upon anything. Just before dark we heard wood-choppers, and Lemon went to spy them out. He soon returned and led the way to three negroes, who had just stopped work, and were about to return to the plantation. We accompanied them to a thicket within a few rods of their master's house, and after they had supplied us with rations, one of their number piloted us to the Aiken road, a distance of about two and a half miles. This brought us within four miles of the South Edisto. The distance between the North and South Edistos at this point is twelve miles. The South Edisto is about fourteen miles north of Aiken, and Aiken is seventeen miles from Augusta.

As we pursued our way towards the South Edisto, we could hear dogs barking far in advance of us, and judged that some one must be traveling the same road, 
-perhaps escaped prisoners,-perhaps a Rebel patrol. This gave us some uneasiness, as we knew they had a decided advantage over us by being in the adrance. However we plodded on, and, when near the river, heard a rustling in the bushes. We then laid low for a few moments, and two men passed us in the clear moonlight. It was impossible to tell whether they were Federals or Rebels, so we decided to watch their movements. After a time we followed, creeping along very cautiously.

\section{CROSSING THE SOUTH EDISTU.}

The South Edisto, in that part of South Carolina, has half a dozen channels or more, which are very narrow, and between them are long narrow strips of marshy land. In fact it is nothing more than a vast swamp, with sereral nearly parallel bayous running through it. These bayous are crossed by bridges, and while crossing one of these we heard footsteps behind us, on a bridge we had just passed over. At this we ran hastily over the remaining bridges, then turned aside and concealed ourselres in some bushes.

Presently the two men previously described came trudging along with the same slow and weary pace. From the manner in which they had manœuvred I felt assured that they were "escaped prisoners," and resolved to challenge them at all hazards; so, stepping boldly from the bushes, I sang ont, "Who comes there?" With a trembling start the foremost man replied, "Friends." I then commanded, "Halt, friends ; advance one, and be recognized." The man steppe? slowly forward, peering into my face, when a mutual 
recognition took place. They also were escaped prisoners from Columbia, and yet we had been dodging each other for more than an hour. Lemon had known one of the officers while in prison.

We at once determined that it was not best to travel in company, yet we pursued our way together, talking over our adventures, until we saw a large fire in the road directly in our front. Stealthily approaching, we found a band of Rebels encamped there, and thought we must be near a picket post; they proved, however, to be a squad of " tax-gatherers," going about the country with quartermasters' wagons, gathering supplies.

Here was an obstacle to our farther progress. There were great ponds of water on either side, and the road was blocked. No amount of reconnoitring could discover a solution of the difficulty. Then there was a resort to stratagem by our newly found friends and ourselves, but both parties resorted to the same tactics. Each wished the other to advance, and incur the risk of a recapture; but neither seemed willing to accept the preference, so we found a safo retreat, and lay down for the night.

\section{Eixtly 灵就.}

AIEEN ROAD, SEVEN MILES SOUTH OF THE South Edisto,

Thursday, December 1.

In the morning the Rebel band of tax-gatherers foruck tents "like the Arabs, and silently stole away." This left the road clear, and we parted company with our friends, jach to try our chances by different rontes. 
Our parting was made memorable by the great thirst from which we there suffered. No relief was accessible, sare in the filthy, nauseating water of the swamps, so we pushed on, hoping soon to find a spring or brook. Our course lay over a high barren, sandy table-land, corered with stunted oaks, and entirely destitute of water. We trareled about seven miles, when we came to a smali stream near whose banks was a beautiful spring. Here we were taught the value of "cold water to a thirsty soul."

This stream ran through a ravine nearly a humlred feet in depth, while high up on the banks were pine groves. It ras a wild, romantic spot, and we could not tear ourselves from it, but las concealed in the grove, groing occasionally to the spring to drink.

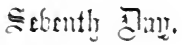

$$
\begin{aligned}
& \left.\begin{array}{c}
\text { IN a Siramp, Near Aikex, S. C., } \\
\text { Friday, December } 2 .
\end{array}\right\}
\end{aligned}
$$

Late in the night we reluctantly bade farewell to the beautiful spot where we had been refreshed so finely, and pursued our journey. Nothing of interest occured. The march was unbroken until near daylight, when we turned into a by-road, and found a hiding-place in some thick underbrush, close by a fine stream of water. It was always our purpose to do this, as we knew thirst would drive us to searehing for water during the day, and thus expose us to danger.

Just at the break of day we espied a colored boy passing down the road with a basket on his arm. Lemon ran out to him, and called ont, "Hold on, my boy, I want to see you ; thinking, meantime, that 
the basket doubtless contained what we most needed, something of an eatable character. We inferred the boy had a chicken with him, for saying that word, in a manner which betokened the greatest fear, the boy set off at a wild run, and would have defied a racehorse to catch him. As for the lieutenant, after exhausting all his rhetoric in endeavoring to bring back the boy, he returned to the spot where I lay, saying, "Now they will have us again, and we shall be prisoners before night."

"Never fear," I said, "as long as there is a swamp in the neighborhood;" and, without further ceremony, we picked up our baggage and hastily decamped. Flora Temple would have been distanced had she attempted to overtake us; for her stakes would have been only a few dollars to her owners, while ours were life and liberty.

We made for a swamp, about a mile away, as fast as our tired limbs could carry us. This swamp lay on either side of the Aiken road, and our place of concealment was so near that the passers-by were in plain sight. While lying here, three ladies came walking down a forest path, accompanied by several hounds. The dogs followed squirrels and other game very near our hiding-place, but we were not discovered.

One of the ladies was telling the others what a fright her mother had early in the morning by the hurried advent of her nigger boy "John," who went to a neighbor's for a chicken. The boy was wild with terror, "having been chased by Yankees," as he said. Thus we learned that our presence was known, and we began planning more caution. 
Towards evening several bushwhackers rode along towards Aiken, with shot guns on their shoulders. They were doubtless thinking that the foolish Yankees would be verdant enough to pass through town at night, and were determined to be ready for them. But we intended to flank the town, and, thinking with satisfaction of our purpose to give the bushwhackers the slip, fell asleep.

\section{Eightly 邹ag.} IN a ConN-Fodder Hotse, Near Aikfn, S. C.,
Saturday, December 3.

We did not resume our tramp until midnight, when, after walking a short distance, we found ourselves in the vicinity of the village, with the road so flanked by streams as to find it difficult to leare it. We then resolved to feel our way carefully through the town, as this would very much shorten our journey; where, instead of enemies, we had the pleasure of

\section{MEETING FRIENDS.}

Deep sleep and quiet lay upon the place, and we passed through withont opposition. On reaching the farthest outskirts of the village, two men, accompanied by a boy, were seen approaching. When they saw us they quickly turned aside into a by-street. This conrinced us that they were escaped prisoners, as Rebels had nothing to be afraid of in those parts We called to them softly, "Don't be uneasy, Yanks we are friends." They proved to be Captain Bryant, of the Fifth New York Cavalry, and a companion whose name I did not learn. They had a negro 
guide, who was to secrete them in a hut until the next night, when they were to proceed as we had done, and reach the lines of freedom by the nearest route. Something of a discussion took place during the few minutes we remained together, with regard to the most feasible course. They had become satisfied, from information obtained, that it was not General Sherman's intention to strike Augusta; hence they concluded it not worth while to go so far out of our way to reach that place. We had also learned that all the boats on the Savannah River had been destroyed south of Augusta, and were satisfied that it would not be possible to cross below that place. They therefore took their course, and we took oursmeaning to cross the river at Augusta, and from thence to strike across the country to Millin, some sixty miles south-east, where we felt certain of finding at least the rear-guard of Sherman's army.

After leaving these friends, with fervent wishes for their success, Lemon and myself started for a swamp in the distance, and, in consequence of difference of opinion arising between us, we became a little confused. The result was that we separated, he taking one route, and $I$ another.

We came together shortly afterward, howerer, and forgot our differences. We reached the swamp, where we secreted ourselves, and soon were gratified to see an old sow with a large litter of pigs approaching. We greeted them otherwise than did wandering Eneas the "alba sus" lying under the hollow trees of ancient Italy,--for, enticing them with crumbs of hoe-cake, we both in unison struck one juvenile 
porker on the head with our heary canes. He died easily, nothing more being necessary to stretch him a lifeless corpse at our feet. No relative waited to attend his funeral. Here "Uncle Zeb's" mammoth knife did excellent service. We dug a hole in the rround, and made a fire of pine-knots, which soon became a bed of intensely hot embers. Orer this we spitted the dressed carcass of the unfortunate little fellow, and, after it was "done brown," sat down to a feast that might hare tempted an epicure. No more luscious barbecue ever excited the salivary glands of a London alderman. This was a peace-offering, though not strictly according to Levitical law. Our asperities were lubicrated for that day.

We heard the sound of an axe in the distance, and I crept cautiously along to reconnoitre. Found it to be a black boy, and, remembering Lemon's experience of the day before, I said, "Hallo, Sambo!" His hat came off suddenly, but he made no attempt to run. The grinning imp, when he learned who we were, gladly led us to a fodder-house near by for concealment; and after dark a large number of colored boys and girls came up to pay us their respects. They entertained us with their views of the war, and proposed a prayer-meeting in our behalf. They also told us where to look out for trouble from bushwhackers, hounds, and so forth. Our parting from these friendly people was tender and affecting, each one shaking hands, and saying, "God bless you, Massa!"

Following their directions, we expected to strike the railroad running from Charleston to Augusta on 
the west side of Aiken, and pursue it west to Augusta ; but instead of this we struck it on the east side, and by mistake, as we had no stars to guide us, we followed the road eastward toward Charlestion.

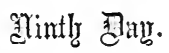

$\left.\begin{array}{c}\text { Destination, Augusta, Ga., Location Unknown, } \\ \text { Sunday, December } 4 .\end{array}\right\}$

Late in the night we passed through a small village just as a freight train was leaving, and tried hard to find a hiding-place in one of the cars, expecting to be carried into Augusta before daylight. Had we succeeded in this, we would have been borne triumphantly into Charleston, and sent back to imprisonment. A merciful Providence interposed. Thus "man proposes," often to his own ruin, but "God disposes," always to His own glory and the good of His creatures.

We followed this railroad all night. A hound was on our track just before morning, but he must have barked on his own rash responsibility, for he soon ceased, and gave up the chase.

Soon after daylight a passenger train came sweeping along, loaded with Rebel soldiers. They set up an infernal shout as they passed; and, fearing the train might be stopped, we turned off into some scruboaks and secreted ourselves. Here we heard heavy cannonading all day. It came from a southeasterly direction, as it seemed to us, and was the sweetest music we had heard for many an hour.

We felt as if we were approaching friends; and we took heart, being hopeful for the future. 


\section{Tently 雨的.}

\section{$\left.\begin{array}{c}\text { Setenteen miles east of Aiken, S. C., } \\ \text { Monday, December 5. }\end{array}\right\}$}

All night we travelled on, wondering why wo had not reached Augusta, and having suspicions that all was not right. During the day we lay in a pine thicket. About dusk Lemon went in search of negroes, and soon found some wood-choppers. They soon informed us of our mistake. We were en route for Charleston, traveling east instead of west, and not having the least desire to visit the last-mentioned city. Our distance east of Aiken was serenteen miles; a bad mistake, we concluded. But Providence still seemed to favor us, for we learned, through our colored friends, that it was possible to cross the Savannah twenty miles below Augusta, at a place called Point Comfort. Our army was marching on Savannah; so we rather gained than lost by our mistake.

Getting a supply of hoe-cake and a guide for a few miles, we started for Tinker Creek, a station fifteen miles distant, and on the way to Point Comfort. We were in excellent spirits, and again undertook to follow the voluminous directions of our colored friends.

$$
\text { Eleforntly 贯aur. }
$$

$$
\left.\begin{array}{c}
\text { Near Tinker Creek, S. C., } \\
\text { Tuesday, December 6. }
\end{array}\right\}
$$

During the night we came to a fork in the road, and, after debating some time as to which course we should pursue, I leaped over the fence, and made for 
a negro hut, while several hounds from the plantation followed hard on my track. I managed, by some tall runuing, to come out a few feet ahead, and bolted into the shanty without warning or formality, slamming the door behind me to keep out the dogs. A great stupid negro was standing in front of the fire, his hands and face buried deeply in fresh pork and hoe-cake, which he was making poor work at eating. His broad, fat countenance glistened with an unguent distilled partly from within, and partly from without. Turning my eyes from the negro to the untidy hearth, they were greeted, as were also my olfactories, with a skillet of pork, frying over the coals.

Without troubling him to answer my questions, I opened the mouth of my haversack, and poured into it the dripping contents of the skillet. I next observed that the ashes on the hearth had a suspiciously fat appearance, and taking the tongs, began raking among them. My suspicions were verified, for two plump-looking hoe-cakes came to light, which were also deposited in the haversack.

Looking around still farther, I saw what I had not observed before,

\section{DINAH'S BLACK HEAD.}

as she peered out from among the bed-clothes, rolling two of the most astonished white eyes that ever asked the question, "What's you g'wine to do next?" Not seeing any practical way in which I could answer her mute question, I said to Sambo, "Call the dogs into the house." 
This he did hastily, when I asked, "Uncle, what road must this Rebel take for Tinker Creek?"

"De right han' one, out dar, I reckon," he answered. Again bidding him keep the hounds in the house till morning, I rushed out to the road, and joined my companion. This ruse I played for the sake of saving time. We made lively work for about three miles, after which we took it more leisurely, stopping to rest and refresh ourselves at every stream that crossed the road.

The weather was very cold, and we suffered much from its severity as soon as we were compelied to lie down to rest.

Abont daylight we found shelter in a piece of woods near the roadside, and slept till ten o'clock in the morning, when we were awakened by some boys driving cows along the road. Some of the animals came within a few feet of us, but the boys kept at a respectful distance.

Thinking our quarters too much exposed, we cantiously crossed the road and plunged into the woods on the other side.

About four o'clock $P$. sr. we heard chopping in the distance, and came to a negro boy who had never seen a Yankee, but concluded it would not be rery wrong to render one a little assistance. Accordingly he brought to our hiding-place, in the erening, several other negroes with corn-bread, bacon, etc. One of their number, an intelligent fellow, rolunteered to gruide us to a place near Point Comfort, on the Sarannah, intending to return before day, and be ready for lis labors, without exciting suspicion. 


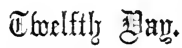 \\ $\left.\begin{array}{c}\text { Near Point Comfort, on the Safannah River, } \\ \text { Wednesday, December } 7 \text {. }\end{array}\right\}$}

Our guide, being in somewhat of a hurry to get back to his work, urged us on more rapidly than we cared to proceed. Seeing that we began to lag behind, he soon offered to "tote" our baggage. We of course could not refuse so generous an offer, fearing that perhaps the effect of a refusal might be to chill the streams of benevolence flowing from his kindly heart. It is certain that there would be no call for kindness, if ererybody should refuse to receive a kindness. Not caring to render ourselves obnoxious to the charge of banishing benevolence from the world, we magnanimously consented to his proposal.

But even this did not seem to affect his gait, and we were still often far in the rear, and obliged to call on him to travel more slowly.

This noble-hearted fellow led us on for fifteen miles, and at last secreted us in a thicket by the roadside, not far from a large plantation. Advising us to find some negro to take us to the Savannah, which was only three miles away, he said good-by, and was off.

Morning revealed to us the fact that we were rather too much exposed to be entirely safe, and as we were very thirsty, with no prospect of water near, we decided to move farther into the woods. This seemed, in a measure, to secure both objects. A large ravine about half a mile away afforded an abundance of water, and we felt that it must be a more safe retreat. A negro who came that way with an axe on 
his shoulder, informed us that boys were in the habit of hunting in the woods, and that we had better seek a more sheltered place.

He pointed to a round sand-hill a short distance away, on the top of which was a sort of pitfall, and advised us to go there, promising to bring some more negroes to us in the evening. Accordingly we made for the sand-hill, and hid ourselves in the pit.

But even this place could not escape the intrusion of boys, guided by no purpose whaterer but their own pleasure. In the afternoon, they came bounding over the hills with a troop of dogs, hunting squirrels, and came within a few feet of finding larger game. This disturbed us again, and we sought another shelter ; and thus, in fear and anxiety, spent the day.

At the appointed time in the evening the negroes came, and one of them piloted us to the hut of some colored fishermen on the Savannah River, which we reached late in the erening.

$$
\begin{aligned}
& \text { Thinternth हlau. } \\
& \left.\begin{array}{c}
\text { In a Crpress Swamp, on tine Saraninan, } \\
\text { Thursday, December } 8 .
\end{array}\right\}
\end{aligned}
$$

These fishermen, who har plied their trade before the war, were acquainted with every bend in the river, and now proposed exercising their skill in our behalf. On a tributary of the Savannah, about a mile from their huts, there lay an old cypress-tree canoe, and to this canoe one of their number conducted us, taking with him a supply of cotton and pitch. This craft had recently come under the boat-destroyer's notice, and had been pretty roughly handled; and yet our col. 


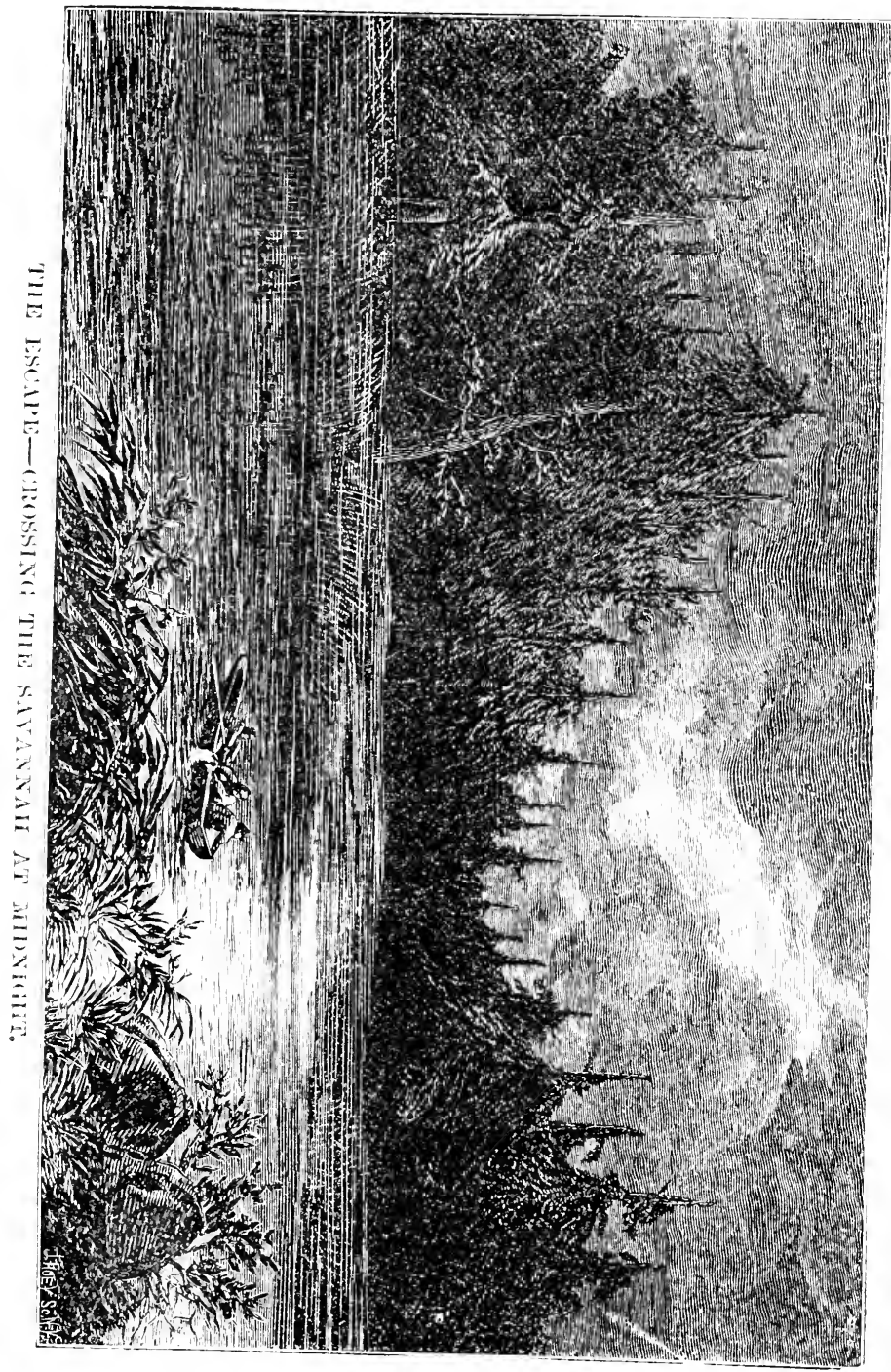



ored friend thought he could make it seaworthy. All night long the faithful fellow worked, caulking and pitching, while we lay concealed in an old hollow cypress log. The ring of his hammer went out through the forest as if bidding a "beautiful defiance" to those who had destroyed his property.

Near midnight, he appeared to have satisfied himself; for throwing her into the stream, he called out, "Now she's ready, Massa. I'll soon land you in Georgy."

The moon was shining brightly, and viewing the shabby dug-out by her treacherous light, I confess to a want of faith in her ability to carry us safely to the other side.

HO FOR GEORGIA.

We lost no time however in speculations, but resolved to put the matter to the test at once. Hastily taking our seats in the small craft, which at once commenced leaking fearfully, our pilot pulled for dear life, while Lemon and myself lustily bailed her out with a couple of large gourds. In spite of our utmost endeavors, the water kept gaining on us, and when within a few rods of the wished-for shore, seeing that she was going down, we sprang into the stream, which happened to be shallow, and dragged the swamping boat up the beach. This was a narrow escape, for had our craft gone down when out in the stream, he alligators would have made our prospects none the brightest. The Savannah here is about half a mile wide. We at once plunged into the swamp, leaving the good negro wadding his boat with cotton, pre- 
paratory to his return. Our prayer was that he might reach the other side in safety, and live to send many other poor fellows on their way rejoicing. We were in the midst of a southern cypress swamp. These swamps extend continuously along both banks of the Savannah, and are about three miles in width. They are thickly interlarded with bayous and small streams, and abound in small lakes and ponds. The ground, in the wet season, is entirely overflowed, and it is next to impossible to travel over it.

\section{THE CYPRESS-TREE,}

which is the glory of these swamps, grows to an immense size. The trunk of the tree, near the ground, swells out somewhat like the base of a cone, terminating in luge roots that stand widely apart. In cutting down these trees, it is customary to build a scaffolding to a considerable height, in order to get above the bulge.

All who have visited these swamps have been struck with the number and appearance of the natural stumps with which they abound. I can call them by no other name. They are all heights from one foot to ten, look like stumps at a distance, are cone-shaped and rounded at the top, and the most of them are alive. The impression conveyed is, that trees of full size had commenced to grow from the ground, and after reaching the height of a few feet had changed their intentions, and concluded that they would grow into stumps. Add to all this the long, trailing Spanish moss that burdens erery tree, from 
the sapling to the king of the forest, and you have some idea of a southern swamp.

In such a place were we-and we wandered about nearly the whole day in our attempts to get out. Great winking

\section{ALLIGATORS}

lay along the bayous, and on every cool, damp log, watching our motions, apparently pleased at our misfortunes, and sending towards us loving, hungry glances. As soon as we approached, they would hobble to the water's edge, and apparently fall in. They, too, might have belonged to some detachment of southern chivalry, doing duty on their own grounds.

Towards night we came to a corn-field skirting the swamp and rising towards the highlands. Here was a most delightfu! spring of water, and near it a kettle of clothes over a fire. Expecting to see the owners in a moment, we lay down in the bushes and waited. Soon a colored man came, found us a hidingplace, and promised to meet us again at eight o'clock in the evening.

While we were waiting a colored washerwoman came, accompanied by several white children. Their contemptible little dog came yelping to within a few feet of our place of concealment, while the children stood back urging him on. His discretion proved the better courage, however, and he became tired eventually, and went away. In the evening our negro returned, and conducted us to some friends of his a few miles off. On the way we met a planter, who was a sort of independent scout. The negro was somewhat 
in advance, and when the planter stopped him, we skulked behind some logs and were not observed.

The whites were on the alert at this place, as it was only a short time since "Mr. Kilpatrick's company had flogged Mr. Wheeler's company right bad," down at Waynesboro', only a few miles distant, as our colored friends informed us. Cavalrymen were patrolling the roads during the whole night, and we began to feel the necessity of the greatest caution.

Our guide led us to a field a short distance from some negro huts, and made our whereabouts known to the occupants. Soon some negroes came out with a generous supply of hot griddle-cakes. We left this place after a brief halt, with a guide who knew where the pickets were stationed, and traveled cautionsly towards Brier Creek, a stream about eighteen miles distant in the direction of Millin.

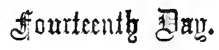

$$
\begin{gathered}
\text { NeAr Brier Creer, Ga., } \\
\text { Friday, December 9. }
\end{gathered}
$$

Before morning our guide left us secreted in a thicket at a fork of roads, about four miles from Brier Creek. Being weary, we soon fell asleep. Nothing occurred to disturb our slumbers, but when we awoke sentinels were guarding us.

Four large hounds stood looking down on us with an air of calmness and responsibility, snuffing occa. sionally to know whether we had the scent of game After we awoke they seemed to consider their guardianship at an end, and, walking around us a little in the most natural manner imaginable, they quietly 
and with murh show of dignity, walked away without deeming it worth while to salute us. We were not much offended at their silent courtesy.

A large cavalry patrol passed near us, and judging it not safe to be very demonstrative, we ate our sweet potatoes raw-they composing our only rations-as a fire was out of the question.

We had, up to that time, no reliable information with regard to General Sherman's army. The bridges across all the principal streams were either broken down, or heavily guarded, to check the advance of raiding parties. The planters drove their stock far into the swamps, and remained with it during the day, returning at night to their plantations.

An old woman came down into the swamp in plain sight of us, and called her "critters" together to feed them. We would gladly have answered the call for ration's sake, had it been prudent.

We found an old darkey near our hiding-place, splitting rails, and warmed ourselves a few moments at his fire, as it was very cold and raining fiercely, after which we sought our shelter again, and made a roof of our blankets to keep off the rain. This old friend promised to find us in the evening, and bring some hoe-cake. What was best of all, he could repair my shoes. These old shoes, like many other unimportant things, have a history. Shortly after my capture I was relieved of my cavalry boots, and a pair of pasted shoes given me, which yielded to the first moisture and left me quite as bad as barefoot. A fellow-prisoner, having received a remittance of good things from home, among them a pair of boots, kindly 
presented me with his shoes. Smile not, gentle read. $\mathrm{er}$, at the gift, for to me they were inv: luable; and with these I marehed many weary miles, although they were patched and wired together until little remained of their former substance, and now they were well-nigh gone. Cuffee took them home, and spent the greater part of the night in making them answer their appointed end. A piece of 'possum skin formed the uppers, which was nicely tucked under. The whole shoe was covered with the skin, and a slit made in the top, in the right place, or somewhere near it, to admit the foot. I was disposed to find fault at first with their generous dimensions, but soon learned, partly from the good darkey and partly from expe-. rience, that the cobbler knew best, for the 'possum skin, though soft and pliable when moist, is hard and wrinkled as a horn when dry.

This man took us in the evening to the negro quarters, and the warm-hearted blacks insisted on our staying with them all night, as it was cold and rainy.

\section{兵iftrenth 包ay.}

Near Godbey's Bridge, five ailes from Alexadder, Ga.,
Saturday, December 10.

Before morning our negro friends conducted us back to the swamp, where we spent another gloomy, disagreeable day. The rain kept drizzling from the clouds and trees the livelong day. We had nothing to eat but an ear of dry corn, picked up on an old camping ground, and refused by some aristocratic horse.

Our black cobbler came at night and piloted us to 
Brier Creek, which we crossed at Godbey's Bridge, and thence proceeded wearily to Alexander. Lemon knocked at the door of a hut, where he found a poor white woman, of whom he inquired the road to Millin, but she knew nothing about it.

Near Alexander we found a huge shanty, about one hundred feet in length, used as the quarters for negroes employed in the Rebel iron-works, which were near. After reconnoitring the building for about half an hour, we entered it. Fortune favored us-the in mates were all negroes, and when we had received a!l needed information as to our best routes, we thanked them, bade them good night, and pushed on. 


\title{
CHAPTER XIV.
}

THE ESCAPE-FOLLOWING THE REBEL ARMY IN GEORGIA.

\author{
Sirtconth 콩. \\ Betweex Sration No. 1 and Millin, Ga.,
Sunday, December 11.
}

Frox Alexander we made good progress until about midnight, when our adrance was intercepted by a large creek. We were in quite a dilemma. A faithful search could discorer no bridge, nor fallen trees spanning the stream, as would be the case in many instances, nor any other means of crossing. The night was bitterly cold, so that ice formed plentifully on still water. And yet there seemed to be no other way but to wade.

Sitting on a $\log$ and ruminating orer our chances, a very selfish piece of strategy suggested itself. Accordingly I said to Lemon, "There is no use of both getting wet; we can carry each other orer these streams. If you will earry me over this, I will carry you orer the next." I said "these streams," although only one was before us, and the most prominent thought in my mind was, that in all probability there would be no other.

Lemon somehow failed to see the point, and con. 
sented. Accordingly, taking off our shoes, I mount. ed on the lieutenant's shoulders, as school-boys sometimes carry each other, and he staggered through the stream with me, doing no worse than wetting my feet. This worked well. I congratulated myself, and gave a generous sympathy to Lemon in his shiverings. The chances were ten to one, I thought, that the carrying business was at an end, when suddenly another stream, wider than the first, rose up in the darkness before us. There was no use in wincing, and I stripped for the task. The lieutenant " ascended to the position he had fairly earned." I plunged into the water. The middle of the stream was reached in safety, when, through no fault of mine, either the water became too deep, or my back became too weak for the burden, and the consequence was, the worthy gentleman was nearly as well soaked as myself when we reached the opposite shore. Selfishness, as well as virtue, sometimes brings its own reward.

We crossed three other streams that night, and as a result of our past experience chose unanimously to do our own wading. Thus another grand scheme for human elevation fell to the ground.

Wet and weary we continued our tramp until nearly daylight, when quarters for the day were chosen in a cypress swamp close by a road over which General Kilpatrick's cavalry and the Fourteenth Army Corps had marched, but a week before.

There were evident traces of their passage. The fences were gone, or lay half-consumed by the roadside. Buildings were still smoking in the distance, or standing charred and blackened. The ground was 
covered with ears of corn, torn haversacks and hlank. ets, "hard-tack" boxes, broken inuskets, cead horses and mules, and any quantity of débris, which may always be found in the desolating track of a large army.

Being much exhausted with fatigue, and the weather being a little more favorable than usual, we slept the whole day without disturbance, as we did also the next night, not awaking until nearly morning.

\author{
Sicfententh 包的.

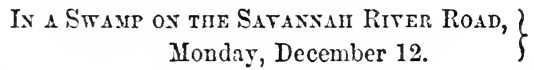

Having wasted the greater part of the night, we determined, at all hazards, to make our time good by traveling during the day. And yet the streams were so swollen that little progress conld be made.

We were evidently on General Sherman's trail, though he was six days in advance of us. In our physical and mental weakness, we wondered whether the good man would halt if he knew we were in pursuit of him. We thought he would at least send a detachment to bring us to his lines. Suffering soldiers can scarcely be induced to think anything of more importance than their own preservation. We determined to turn from the road to Millin, and follow the trail of the army.

Hounds were on our track at one time during the day. Had the wretches known how little there was left of us, they would have given up the pursuit as fruitless, or meatless, at least. It may be that they suspected this, for we were not pursued far. It was 


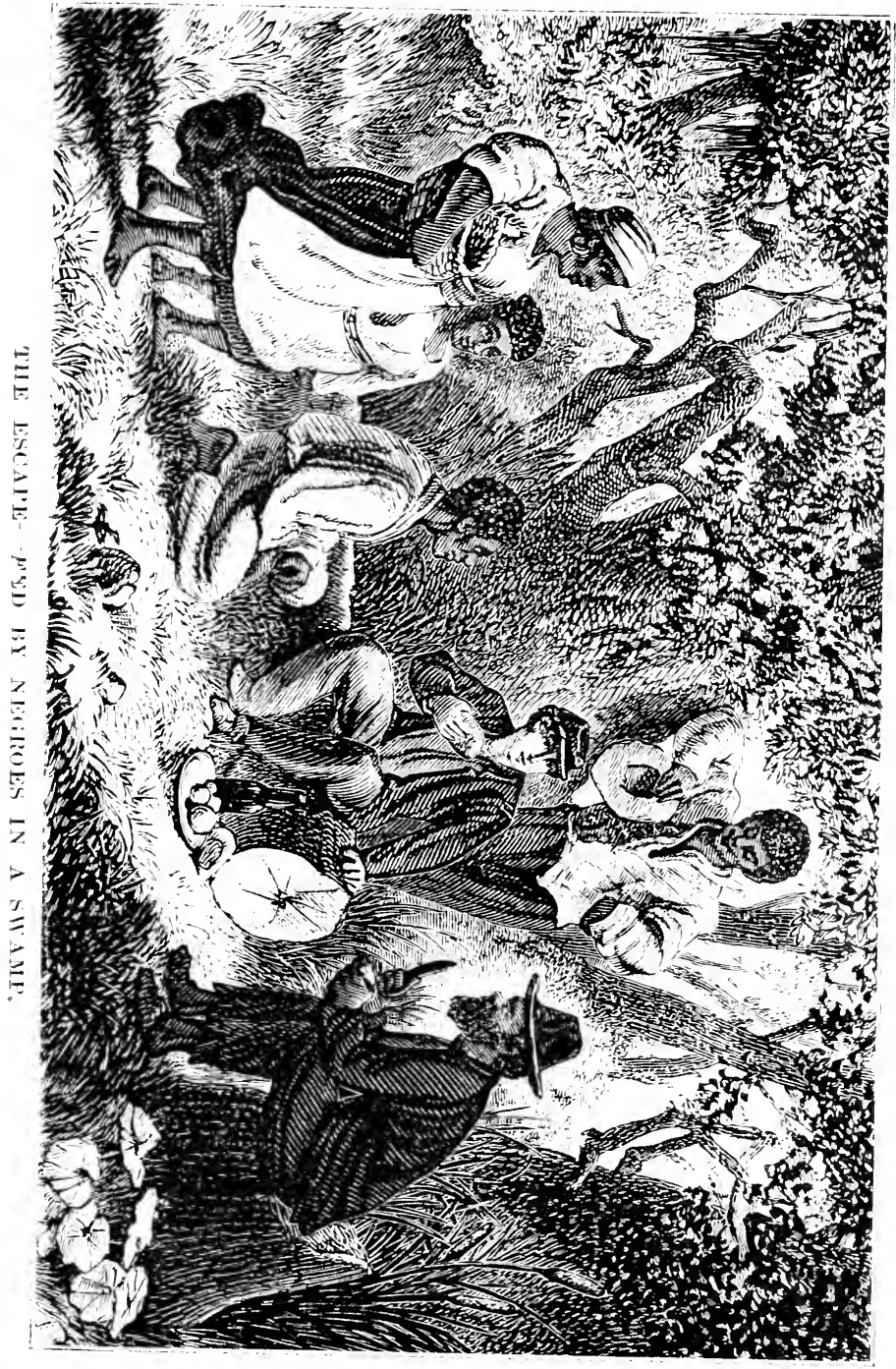



much safer traveling just here than it had been pre. viously; for, as a general thing, Sherman's boys had killed all the hounds in their march, as they had heard of their being used to overtake escaped prisoners. Most of the Rebels, also, had been either carried or frightened out of the country.

One old sinner had unfortunately escaped, and we heard of his hunting Yankees on his own responsibility, and gave him a wide berth. It may have been his hounds that followed us. Nothing could be more desirable, in escaping under such circumstances, than to have a small quantity of strychnine along. There would generally be means of making it an acceptable offering to the dogs.

We turned from the road into a piece of woods, abont four o'clock, and as the country was smoking in all directions, did not hesitate to make a fire and lie down on the grass beside it. During our sleep the fire had crept along the grass and laid hold of my pantaloons; and when I awoke the outside seam of the leg next the fire was burned completely out. The fire had found appropriate food in the dry moss and reeds accumulated there, and so ran along them as it would run along a fence. Some strings from our large tow haversack served to sew the burnt edges together, and by nine in the evening we were again ready to take up our line of march.

\author{
Exighteenth 包ag. \\ $\left.\begin{array}{l}\text { SixtY MILES NORTH OF SATANNAH, } \\ \text { Tuesday, December } 13 .\end{array}\right\}$
}

We continued to travel in the trail of the armies. We were without food, and suffered much from hun. 
ger. Now and then we could find an ear of corn, left by a Rebel cavalryman. In the latter part of the night we stopped at a plantation, and, sceing no plantation house, concluded they were all negro huts. Approaching the most respectable looking one, I rapped at the door, when some one sang out, "Whose thar?"

From the answer, I was unable to guess whether the occupants were black or white, and accordingly said, "Are you black or white in there?"

The answer, "There a'n't no niggers here," and the very indignant tone, satisfied me that I had fallen upon some "poor white trash," as they are familiarly called.

Determined to have something to eat, at all events, besides being anxious to learn something of our course, I assuned the tone of Southern dignity, and, summoning the speaker to the door, I demanded, in the name of an injured Rebel officer, why he was not forthcoming at once.

Upon meeting "mine host," I soon found he had seen his best days; and feeling quite at home, asked how long since our army had passed.

"What army?" he inquired, as if to make sure of no mistake.

"The Rebel army, of course," I replied. He then told me Wheeler's cavalry had passed a week since, in pursuit of Sherman's rear-guard.

"Can you tell me how far it is to Wheeler's headquarters?" I asked.

"Indeed I can't," he answererl, "but I reckon it'? a right smart distance, sir." 
"Are there any horses or mules in the neighbor. hood," I continued.

"Nary one," he replied; "the cussed Yankees have cleaned us out, and done gone with our last piece of bread."

"Well, come now, uncle, can't you give this Rebel something to eat?"

"No, there's not a mouthful in the house; we're whipped clean out."

"I know better, sir," I said; "you have bacon and sweet potatoes; you must shell out, or I shall have to help myself."

Rebel, wishing to shirk the responsibility of a falsehood from his own shoulders, called to Mrs. Rebel to know if there was anything eatable on the premises; to which she replied, "I reckon you'll find something in the pantry;" and in a moment more my unwilling friend returned with a small bit of bread and two sweet potatoes. After receiving these, I delivered him a lecture upon his treatment of a soldier who had ventured all upon the defence of his country; telling him he was unworthy the cause he had espoused, and that his patriotism did not reach to his pockets, to say nothing of his falsehood and mean attempts to defraud me of a breakfast.

Expressing the hope that I should find him a better Rebel when we again met, I hurried off to Lemon; who was still waiting by the road, and with him shared our hard-earned meal with an appetite well whetted by hunger.

Pushing on at a rapid rate in the direction of our army, we espied a person crossing the road a short 
distance before us; and, as the whites seldom stir before daylight, our first conclusion was that we had found a colored friend, but we were soon undeceived by discovering a burly-looking white man. After passing the compliments of the morning, we inquired how long since our cavalry passed. "Last Tuesday," he replied; and not wishing to detain him, we proceeded on our way, grateful that our uniforms were hidden under our blankets, which answered at once as overcoats and a good disguise.

Leaving planter No. 2 to his own reflections, we reached a swamp at daybreak. Here we met two negroes going to their work, and, after a "Good morning, boys," inquired the distance to the next plantation.

"Jess a mild from this 'ere swamp, Massa."

"Are there any white folks there?" we asked.

"Nary one, Massa, for

\section{DE Planter was a BUshwacker,}

and Massa Sherman's company took 'em all orf."

Wishing to have my stories of the morning agree (not knowing how soon they would be tested), I did not think it necessary to make myself known to my colored friends, but asked whether they had seen any of Wheeler's cavalry of late.

"There's right smart of 'em down at Massa Brown's, three miles from de swamp, and dey's hazin' about de country in eb'ry direction."

Feeling somewhat disconcerted with this piece of information, we, however, started for the plantation desoribed. As we came in sight, I saw the house was 
closed, but that smoke was rising from a hut on the grounds, so made for it in double-quick time ; walked up to and opened the door without hesitation, when to my surprise and horror, I beheld

\section{A REBEL OFFICER}

sitting before the fire. Without the least hesitancy or trepidation, I advanced, gave him the military salute, and said, "I see you too are in the service, sir; but hope, like myself, you have not been unfortunate."

"How unfortunate may you have been, sir?" he asked. Now I might have stated all the mishaps of my life; but only quietly said, "I was in the cavalry fight at Waynesboro' the other day, had my horse shot from under me, failed to get remounted, and have walked the entire distance to this place."

"I reckon our cases are not very unlike, after all," he rejoined; "I had my horse shot there too, but luckily got a mule;" and, stepping to the door, he pointed out his long-eared animal, eating hay at the barn.

Fearing be might get the start of me, I asked to what command he belonged.

"The Fifty-third Alabama Mounted Infantry," he returned; and then inquired my regiment.

"The Third South Carolina Cavalry," I said ; and true it was, that my last service was in that State.

I was careful to name some other State than Alabama, as he would be better posted with regard tc the regiments of his own State than those of any other. Lemon, during this time, was walking uneusily backwards and forwards in front of the gate. 
He once carelessly remarked that we had better be going, but I thought haste would be the ruination of us, and so occupied a few minutes more in recounting the barbarities of General Sherman's army, remarking, "Now we have him just where we want himbetween two swamps; and when he is thoroughly. starved out we shall capture his entire army."

The lieutenant seemed to indorse my remarks, notwithstanding my blue clothes; and just as I thought his suspicions fully allayed he remarked that "it was strange for a gentleman of my professions to be dressed in Federal colors."

I returned, "It is not strange at all, sir. A poor fellow must wear what he can get in these times. I have not had a full equipment since I came in to the service, and I never expect one. You know, in the fight at Waynesboro' we captured a few Yanks; and I just stripped a dead one, and appropriated his attire to myself."

"A good idea," he said, pointing to his own tattered pants ; "I wish I had been as sensible."

My poor stomach had gained nothing during this interview, so I asked, "Do you reckon aunty"pointing to the woman of the house-" could give me some breakfast?"

"I reckon not, stranger," he returned; "the Yanks have done gone with all the corn on this plantation; but if you will go down to Mr. Brown's, you can grit all you ask for. He was a good Union man when General Sherman passed through, and on that accorut had a guard set over his property; then, wher our army came along, he was all Secesh." 
"Well, sir, I shall be at Mr. Brown's without delay, and shall be happy to breakfast with you there. How far do you call it to his plantation?"

"About two sights and a jambye," he returned, in true Rebel parlance.

A "sight" was as far as one could see in that broken country, while a "jambye" nothing more than a swamp,-terms which gave me a very accurate measurement of the distance.

But, not interrupting him for any explanation of his Southern vocabulary, the good otticer continued to inform me that it was fifty-two miles to Savannah, about thirty-five to the rear of Sherman's army, and twenty-five to Wheeler's headquarters, adding as he closed, "It's a smart walk you'll have, I reckon."

With a hearty, "Thank you, sir, and a good morning; we shall meet you at

\section{MR. BROWN's,}

we left him, and kept the road until entirely out of his range, when we suddenly struck into a swamp. Messrs. Brown \& Co. may be still waiting that breakfast for us, for aught I know; may they wait and watch with due patience.

We made rapid strides for a mile or more, and finally concealed ourselves in some bushes. Seeing a smoke in the woods, we crept towards it, and found a black man and his wife, interesting contrabands, lying by the fire. After arousing them, we learned their history.

They had followed General Sherman's army from Burke County, Georgia, and, being encamped on an 
island in Big Ebenezer Creek, with four or five hundred others, were shelled out by the Rebels, and compelled to seek safety by flight into the swamps.

In this way they had lost their company, and reasoning that if the slaves were all emancipated they would be free when the war ended, without any trouble of their own, they resolved to go back to their master's.

We were at this time without food and very hungry, and as our colored friends had nothing but a little shelled corn, we lent Sambo our harersack, and sent him to find some negroes, detaining Dinah as a hostage for his safe return. He rather objected to the risk of such an expedition, but as we were very urgent, at last complied, while we sat roasting and eating corn during his absence. He brought back some sweet potatoes, which were in no way oljectionable.

Very soon the worthy comple decided, after a little persuasion on our part, that they were not in very safe quarters, and consequently left us in full possession of the fire and potatoes, the latter of which we roasted in the former. Here we spent the remainder of the day and the early part of the following night.

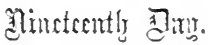

$\left.\begin{array}{c}\text { Ox the Sataxan Piver Rodd, } \\ \text { Wednesday, December } 14 .\end{array}\right\}$

We did not travel much till after midnight, when we pursued our way without interruption till daylight; then turned into a swamp. We heard the sound of an axe. Early in the afternoon, Lemon 
went to reconnoitre, while I sat down to write in $m y$ journal. I had no pencil of my own, but Lemon had a short piece which he kindly lent me. Having no knife, I was obliged to sharpen it by picking the wood away from the lead with my finger nails.

\section{CRITICAL SITUATION.}

Lemon soon returned in extreme consternation. Seeing a negro, he had walked boldly up to him, when, to his utter dismay, he saw a great burly white man sitting on a log. Springing from the log; the planter demanded almost in a fury, "What are you doing here in a blue uniform ?"

The lieutenant replied, "I am serving" my country, as every loyal man should do."

The planter then said, "I believe you're a d-d Yankee."

Lemon returned the gallant answer, "You are welcome to your opinion, old Blowhard,-this is a free country. I am a Yankee-all but the $\mathrm{d}-\mathrm{d}$ -and what do you propose to do about it?"

"We'll see, we'll see," said the planter, and at the same time started hurriedly toward the house. Lemon came back double quick, and we suddenly decamped, supposing of course that the planter had gone for his gun and hounds.

Taking the sun for a guide, we set off in a southeasterly direction, and did not venture to halt before dark.

We were pursued by hounds for more than two miles, but struck a stream of water, and waded up a half mile to erade our pertinacious followers. This 
put them off the scent, as it usually did. The cow. ardly old stay-at-home had been true to his instincts. Nature had printed no lie on his face. He might have taken Lemou by the collar, and walked him off to his home as he would a negro boy; but his big fists had no manly courage to back them, and he lost his prey.

During our run tre found some ears of corn and a piece of pork, left by the army. The meat was badly tainted, but nc natter-it was no time to be fastidious. Making a small fire, we roasted it, and made a good meal. There was no prospect of better, for the country was thoroughly stripped, and there were very few negroes left to befriend us.

As we loitered around our little fire, we observed, through the bushes, several planters galloping along to take possession of Sherman's corduroy road through the swamp just ahead of us, thinking, no doubt, that we could not possibly find another passage through it. This put us on our guard, and we secreted ourselves securely until late in the night, when we determined again to rob these hunters of human game of their prey, by flanking their position.

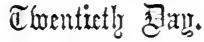

\section{$\left.\begin{array}{c}\text { In a Swamp near Big Ebenezer Creek, } \\ \text { Thursday, December } 15 .\end{array}\right\}$}

It was about midnight when we began to creep cautionsly up to the edge of the swamp. A large fire soon marked the locality of the planters' picket. We could do nothing but venture out in the mud and water of the hateful swamp, which we did on the left flank of the guarding party. 
It was a terrible undertaking, but there was no alternative. Sometimes we were whelmed to our armpits in the holes, and had it not been for the roots of trees and bushes, upon which we could step and seize with our hands, we could never have escaped with our lives. And had it not been for the severe exercise, we would have perished with the cold. But hope and labor kept our bodies and spirits warm, and so we pushed our way through as best we could. If Bunyan's pilgrim had half as hard a task as this when struggling through the Slough of Despond, we felt to pity him, and to glory in his perseverance and success.

At no time were we further than about fifteen rods of the pickets, and in consequence of the many obstacles in our way, and of frequently stopping to rest, and of moving so cautiously to avoid any noise, we were about two hours in going only a few hundred yards. But we escaped our wily adversaries safely. Several other pickets, however, were passed later in the night; to some of them we were so near as to hear their conversation about the "desolating march of Sherman's hosts"; but, as the ground was firmer, we had no difficulty in turning their flank. The last picket was passed at the edge of the swamp skirting the Big Ebenezer Creek. This swamp was corduroyed, but unguarded.

On either side of the road the land was entirely submerged, and it would not have been among things possible to travel through it. Three miles or more brought us to the stream, which was very wide.

The bridge had been burned, and we stood on the 
charred abutment, surrounded by water, with no visible means of making a crossing. All our inspection could bring to light nothing satisfactory. Daylight was just coming, and, through the rising mists, we could discern the opposite shore. Did the Israelites more earnestly long for the Arabian shore of the Red Sea, than we for that misty land beyond the stream? They were pursued by the hosts of Egyptian tyrants, we, by no less blood-thirsty Rebels. A sense of desolation crept over us. A broad stream lay before us, and an impenetrable swamp all around, while we possessed nothing but "Uncle Zeb's" knife to assist us.

We finally thought of secreting ourselves, and of stealing back past the pickets at night, to get boards with which to constrnet a raft. Just how this was to be done we did not know; but it was a plan, and better than no plan at all.

Accordingly, we began to search for a place of concealment, and soon found very

\section{UNEXPECTED AID.}

Walking back along the road towards the picket, we saw what had the appearance of being a corduroyed walk leading out into the swamp. Following this, and jumping from $\log$ to $\log$, we soon came to an island, or elevated plat of ground, in the midst of the swamp. No diseussion was needed to determine that this was the place we were looking for. Men had evidently rested there before. Old pieces of garments and blankets were strewn around, and here and there were the charred remains of fires. Select- 
ing as secluded and cozy a spot as possible, we soon fell asleep, being weary with our long and dreary trainp. Our nap, however, was very short. Lemon soon shook me by the arm, and whispered in my ear that he had heard a noise like that of oars falling into a boat. Most persons are familiar with this peculiar ringing sound.

Wide awake then, we watched the road, and soon saw two Rebel couriers pass along with papers in their hands.

After waiting till they were well past, we crept out of our lair, and watched them till they were out of sight, when we went down to the river's edge. Here we found an old boat, drawn up among the trees of the swamp, and tied with a rope.

Seeing the coast apparently clear on the opposite side, it was the work of a moment only to get the craft back into the stream. There was no quarreling for the post of honor, but each making the best use of the two broken paddles with which the boat was equipped, we were soon landed "on the other shore," having passed "dry-shod."

After pushing our boat down stream, we discovered the body of a dead cavalryman. From his general appearance, and the few fragments of uniform remaining unpilfered upon his body, we concluded he was a Federal soldier, and though unable to give him a decent burial, we gently laid him in the water, and left the monrnful spot in haste. Following the corduroy, we soon came to two horses tied under the trees. They evidently belonged to the couriers. It was a hazardons aftair throughout, but thinking tho 
danger would be no greater on horseback than on foot, we borrowed the gentlemen's horses.

We had a splendid ride, the first for many a weary month, and we sailed along like birds, for at least two miles, when, the country becorning more open, and it being in broad daylight, we reluctantly dismounted, slipped bridles, and let the noble animals loose to grass. We thought the horses were quite as well satisfied with our treatment, as they would have been with that of their true masters, and we parted frcm each other with mutual regrets.

Turning into the woods we soon heard roices in the distance. They proved to be Rebel pickets. Fearing to venture any more that day, we found a close retreat, and lay down for the day, employing our waking hours in eating corn from the cob-our only diet for sereral days. Quietly we slept until nearly midnight, and, then, flanking the picket before us, we pursued our dangerous journey. 


\section{CHAPTER XV.}

RE-CAPTURED BY A REBEL PICKET.

T lonenty-first 콤ag.

$\left.\begin{array}{c}\text { Twenty Miles from Satankah, Ga. } \\ \text { Friday, December } 16 .\end{array}\right\}$

As we lay in our hiding-place near Big Ebenezer Creek, we congratulated ourselves on the wonderful preservation we had experienced thus far. Our narrow escapes from alligators, and hounds, and worse men ; our successful disguises, and transits over difficult streams and swamps; and the very kind treatment we had invariably received at the hands of the despised colored man,-all these came up in review, and seemed to give us a foretaste of final triumph. It seemed as though our toils and dangers were nearly over. Our hearts beat high with delight at the thought that we were not far from the Federal lines, and that a few hours' walk would bring us among our friends. Elated with past success, and flushed with hope for the future, we left our place of concealment with joyous hearts and invigorated frames, though we had been more than thirty-six hours without rations of bread or meat, subsisting on all almost nothing.

We were without guides, and with no detinite information with regard to the position of the contending armies In fact, we were groping our way along 
like blind men, driven about from point to point by the yelping of hounds, or the arrangements of picket'ines, or the morements of troops.

About midnight we reached Little Ebenezer Creek, and, to our great chagrin, we found the bridge destrojed.

After a few moments' reconnoitring we became satisfied that no pickets infested the opposite shores. Luckily for us we found several pieces of broken boards and planks with which, haring constructed a raft, we safely paddled ourselves across the stream.

Caution was now the general commanding, for we knew that dangers increased with every step. Old camping grounds were numerous along our way, and each was examined closely for crumbs of hard bread, or any other eatables that we thought might have been left by our army; for we were now'on the Savannah River road, over which Kilpatrick's cavalry and the Fourteenth Army Corps had passed but a week before.

Just as we were about turning from the road for the abore-mentioned purpose, a gruff roice sent out the terrible challenge,

\section{"WHO COMES THERE?"}

I had long ere this decided upon the course to be pursued in case we should be so unfortunate as to run upon a picket; but being too near the challenger to make running a safe expedient, I answered withont hesitation, "Friends." Upon which the picket commanded, "Adrance one." I advanced promptly, and, arriving near my captors, found them to be mounted infantrymen. They were sitting upon 


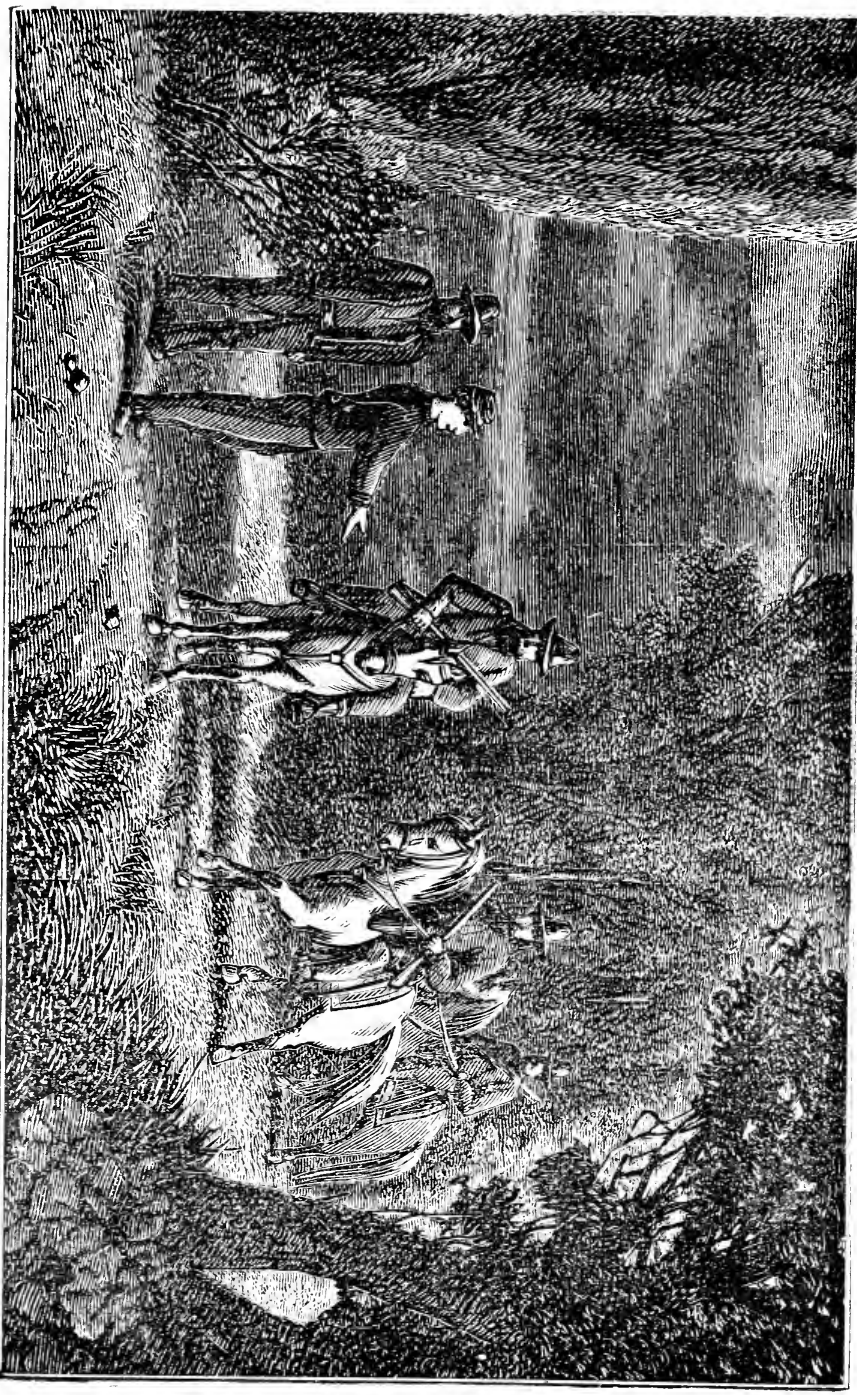



their horses, in the shade of some cypress-trees. One asked, "Who are you ?" to which I replied, "I am a scout to General Hardie, and must not be detained, as I have important information for the general."

The sentry replied, "I'm instructed to take every person to the officer of the picket that approaches this post after dark."

"I can't help it, sir. It is not customary to arrest scouts, and I must pass on."

"You cannot; I must obey orders. I do not doubt the truth of your assertion; but until you have seen the lieutenant, you will not be allowed to pass this post."

Finding that I had met a good soldier, I saw that it was useless to trifle with him, and tried to console myself with the thought that I should be able to dupe the officer; and as we were hurried on toward the reserve of the picket, my mind was occupied in arranging a plan for our defence, as spies to the great "Rebel Chief." Reaching the reserve, we found nearly all asleep, in close proximity to a large rail fire, including my antagonist, the lieutenant.

A little rough shaking soon roused him up, and, rubbing his eyes for a moment, he asked, "What's wanted?"

I quickly answered, "I'm surprised, sir, that scouts to our generals should be arrested by your picket."

He said, "My instructions are positive, and no man can pass this post withont examination."

"Very well, then," I said, "be good enough to ex. amine us at once." 
"Have you passes?"

"No, sir; not at present. We had papers when we left the general's headquarters; but having been scouting in Northern Georgia, for the past two weeks, our papers are worn out and lost."

"You have some papers about you, I suppose?"

Thinking that by answering in the affirmative, and producing quickly an old package of letters which had been received while in Libby Prison, that none of them would be criticised, I hastily drew them from the side-pocket of my jacket and held them before me, saying, "I hope here are enough, sir."

The lieutenant's curiosity led him to take one which had been receired from Colonel C. Buel, of Troy, New York.

REGARDED AS A SPY.

He held it near the fire, and noticing the date, turned his eyes towards me and again to the letter; the second glance seemed to satisfy him that I was not a Rebel, and he remarked very indignantly, "Then you are scouting for General Hardie, are you? I believe you are a $\mathrm{d}-\mathrm{d}$ Yankee spv, and if you were to get your just deserts I should hang you to the first tree I come to." Said I, "Lieutenant, do not be too hasty, I can convince you that I have been a prisoner of war, and if you are a true soldier, I shall be treated as such."

Becoming a little more mild, he gave us to understand that we should start at ten o'clock the next morning, for Springfield, the head-quarters of Gen. eral Wheeler. 
After detailing a special guard for the prisoners, and instructing them to be on the alert, the lieutenant laid himself down by the fire, leaving us to reflect upon the hardness of fate, and the uncertainties attending an effort to escape the clutches of a barbarous enemy.

\section{NOT YET DISCOURAGED.}

After a while I found an opportunity of speaking to Lemon, and secretly communicated to him my intention of making another attempt to reach the Federal lines. I told him that I did not know what he had determined to do, but as for myself, I should never return to South Carolina, a prisoner. I recounted to him the horrors and frightful consequences of prison life, and the privations and long suffering attending our attempt to escape from the hands of our merciless enemies. I told him that in my estimation it was quite as well to be hung by bushwhackers or torn to pieces by hounds in Georgia, as to return to South Carolina to meet a miserable death from starvation and exposure. Our case was a desperate one, and I was ready for any expedient.

Lemon seemed to agree with me in every particular, and although he made no decisive answer, I concluded that I could count upon his co-operation. While with the picket, we learned that we had been arrested at the outpost, and that if we had been so fortunate as to pass this post, we might have reached General Sherman's lines in less than an hour. This intelligence was very disheartening indeed, when we saw that but a step intervened between suffering and happiness. Still, I endeavored to look upon the bright 
side of the picture, thinking that if I could but have another chance in the "swamps," I should be more successful.

\section{REBEL KINDNESS.}

I shall never forget the kindness of James Brooks, one of the pickets, who came to us a little after daybreak, and asked if we would like some hoe-cake and bacon. He said he had been out "prowling" or "bumming," whichever way we might call it, and he would now share his rations with the prisoners.

We answered in the affirmative, as a matter of course, having been without food for more than fortyeight hours, save a few ears of corn which we had been so fortunate as to find by the roadside, where the caralrymen had fed their horses. In a moment more the hoe-cake was forthcoming, much to the disgust of our friend's comrades, who called him "bluebelly," and said he must be a fool to give his bread to "the d-d Yanks." He made no reply to their insults, but set before us a most excellent breakfast.

\section{AN ATTEMPT TO BRIBE THE GUARD.}

After we had finished the hoe-cake and bacon, we asked permission to pass under guard to a little stream of water which was in sight of, and but a few rods from, the reserve.

The favor was granted, and after we had taken a bath, I endeavored to bribe the guard by offering them one hundred dollars in "Confederate scrip" (which had been given me by the negroes), if they would give us an opportunity to make our escape.

They said they would be right glad to have the 
money, but feared the consequences, as they were held responsible for our return. I told them that if they would listen to me, I would show thein how they could make a good pile of Confed., and have no fears of $\mathrm{T}$ anishment.

As we could be easily seen by the picket, my plan was to apparently take advantage of the guard by setting off at a run for the swamps, when they were to turn in pursuit, and without taking aim, fire in our direction.

I was confident that the scheme would work admirably, but the guards seemed to distrust each other, and instead of acceding to my proposition, they marched us back to the picket, and reported that we had attempted to bribe them. The lieutenant ordered a search at once, and what little scrip had been given us by our colored friends was soon in the hands of the "gray jackets." We were also threatened with serere punishment; one said, "Shoot the d-d Yankees; another,

\section{"LET 'EM STRETCH HEMP."}

Several reckoned that they had better take us into the swamp, and send us after Sherman's raiders; referring, I suppose, to the manner in which they had disposed of some of our sick that had necessarily been left in rear of the army; for, before our recapture, we were told by the negroes, that fifteen of our sick who fell into the hands of the Rebels but a few days since, were taken to a sivamp, where their throats were cut, and their bodies thrown into a slough hole.

I cannot vouch for the truth of this statement; but 
it carne to me from many whose veracity I had no reason to doubt.

Our guards were universally applauded for their fidelity; but I am thoroughly convinced that if either had been alone, he would have thanked me for the suggestion and pocketed the money.

We remained with the picket until ten o'clock A. Mr., when a guard, consisting of a corporal and two men, were detailed for the purpose of taking us to General Wheeler's head-quarters.

We had not proceeded far, however, when very suddenly I became so foot-sore as to render it seemingly impossible for me to walk, which I claimed was the result of my long tramp since my escape from Columbia.

\section{ONCE MORE IN THE SADDLE.}

I afiected to be too weak to mount without assistance, and allowed "Johnny Reb" to help me into the saddle. It was not long before we came to some little trees by the roadside, and, riding under one, I broke off a small branch which I thought might be of some service in the future; for I was no sooner in the saddle than I had decided to effect my escape by tlight, and determined to watch my opportunity.

I had ridden the Rebel charger but a short distance, when the guard espied a black squirrel a few rods from the road. Forgetting the responsibility of his detail, he set out at a wild pace after the squirrel, which, after darting off a short distance, ran up a tree, and then, as if to show his superiority over Blondin, leaped from limb to limb with an expertness creditable tc bis species. His follower was upon the point of giv- 


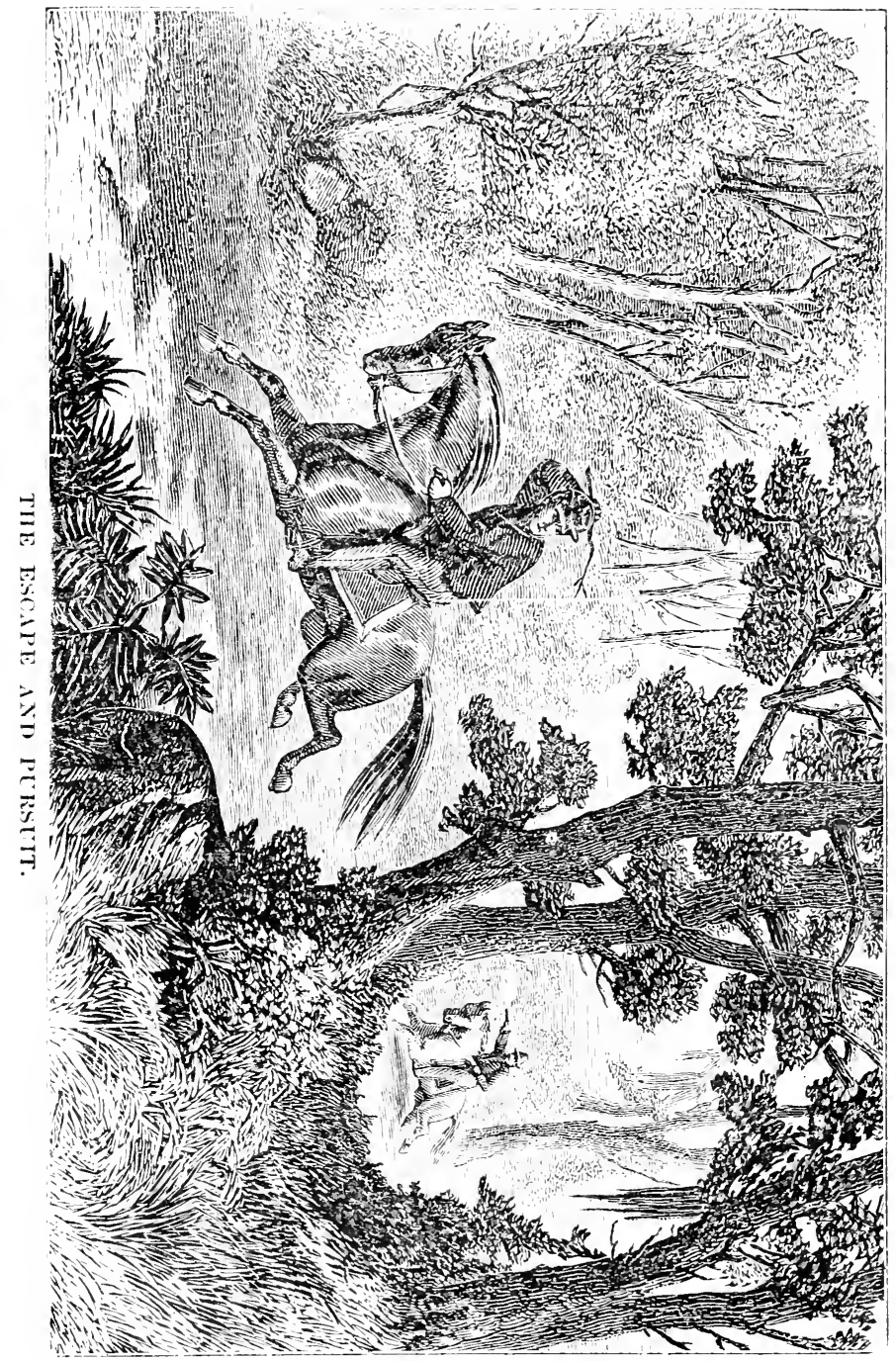



ing up the chase as a poor investment, when, sudden. ly, the little fellow halted, and perching himself upon a limb, seemingly bade defiance to pursuit. I could not help regarding this little animal with some favor: for it appeared that he was about to sacrifice his life to my interests.

\section{TIIE ESCAPE AND PURSUIT.}

The carbine was instantly brought to the shoul. der, aud its report told me that then was my time, while the piece was unloaded; and, without waiting to mark the result of the shot, I whipped up and dashed off at a fearful rate, urging my charger to the top of his speed.

I was noticed immediately by the corporal, who left the other guard with Lemon, and came after me in a manner that was not the most flattering to my prospects. He was armed with a Colt's revolver, and while in pursuit discharged its contents at my unfortunate self, ordering me to halt at every shot. I paid no attention to the summons, but continued to urge my pony to his utmost. His pace, however, at the best, was quite unsatisfactory to my wishes; for had he been more Heet, I could have distanced the corporal, dismounted, and got into the swamps out of his reach in a few moments. But disappointment was again to mar the day. I found myself unfortunately approaching a Rebel camp, which was situated on both sides of the road. I turned my horse, leaped a fence, and endeavored to make my way across an open field; but the corporal's demand, to halt the $d-d$ Yankee, was responded to by not less than fifty Texan rangers, 
from General Irerson's Cavalry Division. They came hooting and yelping, mounted and dismounted, armed and unarmed. Several blazed array at me with carbines and revolvers, but without effect.

I was, howerer, soon overtaken by fresh horses, and compelled to surrender myself once more a prisoner of war into the hands of the Texans.

The guard, whom I thought so kind, and whose horse I had thus unmercifully ridden, came up in time to heap a most fearful tirade of curses upon me before we again resumed our march.

The Texans seemed to enjoy the sport hugely. One of them said to the squirrel-hunter, "You are a d-_ d smart soldier, you are, to let a blue-belly get away from you-and on your own horse, too!" Another put in, "I sas, corporal, which of them nags can run fastest?"

The corporal had little to say, and as soon as Lemon and the other guard came up he started us on. We were then forced to walk the entire distance-my lameness exciting no further sympathy from the mortified guards.

ARRIVAL AT WHEELER'S IIEAD-QUARTERS.

We reached General Wheeler's head-quarters late in the afternoon, and the corporal reported to the general that he was in charge of two prisoners that had attempted to pass the out-posts as sconts to General Hardie. Wheeler ordered us into his presence, questioned us closely, and ordered our clothing searched. This inrestigation over, we were sent to the ccunty jail and locked up in a cell, ten by fifteen feet, to wait 
orit trial as "Yankee spies." We considered it an easy matter to prove our identity as escaped prisoners, and the only facts that could tell against us were, that I wore a gray jacket, and that we had representerl ourselves to be scouts to a Confederate general.

I shall ever remember our interview with General Wheeler; for it was quite an amusing scene, and illustrates, to some extent, the character of that Rebel cavalry chief, whose career in the South and West had made his name so famous in the history of the Rebellion. He first said to us,-

"Then you are scouting for Confederate generals, are you?"

I replied, "We would have rejoiced could we but have convinced your outpost that we were-"

"None of your impudence, sir. Remember that you are a prisoner."

"Very true; but when you ask questions, you must expect answers."

"What are you doing with that gray jacket?"

"I wear it, sir, to protect myself from the sun and storm."

"Where did you get it?"

"One of the guard at Columbia was kind enough to give it to me, when he saw that I was suffering for the want of clothing with which to cover my nakedness."

"He could not have been a true Rebel, thus to assist a Yankee in making his escape."

"He knew nothing of my intention to escape; and I believe he was, at least, a sympathizing, kind. hearted man." 
"Why don't you wear the Federal uniform? Is it possible that the Yankees are ashamed of the blue?"

"By no means, sir. What few garments were spared me at the time of my capture were worn out during a long imprisonment, and the clothing which was sent on to Richmond by our Government during the winter of 1863 for distribution among the prisoners, was, for the most part, appropriated by your authorities."

"Like many others of the contemptible Yankee crew, I believe you to be a lying scoundrel, and you shall answer to the eharge of spy."

"Very well, sir, I am compelled to await your pleasure ; but you have heard nothing but the truth."

"Guard, take the prisoncrs to the jail, place them in a cell, and keep them in elose confinement until further orders."

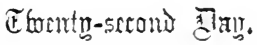

$$
\begin{aligned}
& \text { Coextr Jail, Springfiedd, Ga., } \\
& \text { Saturday, December 17. }
\end{aligned}
$$

Springfield is a rery pleasant little village, on the Middle Ground Road. It is the County seat of Effingham county, and, before the war, contained several fine public buildings, which have recently been laid in ruins by the hostile armies.

We were the only military prisoners confined in the jail, which was then in the hands of the military authorities. We were kindly allowed to leave our cell and go into the yard to take the fresh air. The news spread rapidly that there were two lire Yanks in the Jail yard. 
The citizens became alarmed and enraged to think that we should be permitted to leave the cell, and threatened to take the keys into their own hands, if we were not taken back.

The officer in charge told them that he was per. sonally responsible for our safe keeping, and that they need not give themselves any uneasiness.

Crowds of people gathered around this yard and looked upon us with the greatest wonder. Discovering that we were comparatively harmless, and were human, several ventured to ask us many curious questions. I found them to be the most ignorant class of people that I had ever met in the South. Many of them supposed, until very recently, that all Yankees were cut out after the pattern of Diabolus, which our good old grandmothers used to take delight in pointing out to us, and consisted of an ugly-featured creature, with horns and hoofs, and usually armed with a pitch-fork or scythe.

Their ideas of our good President and of the war were laughable in the extreme. Their mode of speech was as bad as that of the most ignorant slaves we had met on the plantations. Ignorance among the masses of the white people in the South is as general as it is shocking. Education is confined to the few, whose wealth enables them to send their children to northern schools, or to engage a northern teacher as private tutor in their families. School-houses are scarcely ever found, and thus gross darkness envelops the people. This may account for the vast power which southern politicians exercise over the masses, a power which will diminish as enlightenment increases. 


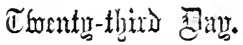 \\ Middle Grodxd Road, near Sprixgfield, Ga., $\}$ \\ Sunday, December 18 . $\}$
}

In the afternoon, we were brought up before a Military Commission, composed of officers from General Wheeler's staff.

The officials had already became pretty well satisfied that we were only prisoners of war, and all they did, was to ask us where we were captured, where we had been imprisoned, when we made our escape, etc. This farce of a trial being over, a heavy guard was detailed from the Second Georgia Cavalry, with instructions to proceed with us to Waynesboro', together with fifteen prisoners from our Fourteenth Army Corps, who were captured while out on a forging expedition a few days ago.

From them I gained much valuable information concerning the situation of our army.

I also learned where the Rebel troops were stationed in General Sherman's rear. Such information was very important in the event of another attempt to escape. No rations were issued to us. The Rebel troops depended entirely on foraging for their supplies, and seemed to care very little for the wants of the prisoners. A few ears of corn were all we had to lieep soul and body together. As night drew on, we were in rery low spirits, owing to the fact that all attempts to elude the vigilance of the guards during the day had failed.

I first urged the prisoners to straggle, so as to 
lengthen the column as much as possible, thinking that if we were permitted so to do, I might succeed in dodging into a swamp unobserved; but the vigilant sergeant was too shrewd to be duped in this manner, and instructed his men to keep us closed up.

Failing in this scheme, I hoped that the sergeant would continue to march us during the night, in which case I could take advantage of the darkness and make off at my pleasure; but in this plan also I was destined to be disappointed; for much against my wishes we came to a halt but a few moments after dark, and were hurried into an old building for the night.

Just before halting we passed through a large swamp, where the water was so deep in the road as to compel each man to use his own discretion in making his way through.

The guard did their best to keep us together and prevent escapes; but in spite of their exertions one of our enlisted men fell out, whose absence was soon noticed by the sergeant.

\section{VERIFYING REBEL DETAILS.}

We succeeded in convincing him that all the prisoners were present with whom he had started from Springfield. Our programme was this: I found out the absent man's name; and then, as the sergeant had a list of the prisoners, I volunteered to call the roll for him.

After getting us into a safe position, he lighted a piece of pitch pine, and handed me the list, while I proceeded to call the roll. Every man present an 
swered promptly to his name, but when I came to the name of the absentee, (according to previous instruction) all aftirmed that no such man had been among us. The sergeant concluded that said name had found its way upon the roll through mistake, and no further search was made.

Under ordinary circumstances, I should be far from volunteering to aid a Rebel in verifying his details; but, in this case, I thought that by a little ingenuity, a fellow-sufferer might return to liberty; for had not this scheme been devised, strenuous efforts would have been made by the guards to insure his capture. Picked men would have been detailed, hounds called out, and a few hours, at the furthest, would doubtless have convinced the unfortunate victim how little hope there is for him who seeks to shun the horrors of prison life by an escape.

Our quarter's for the night were tolerably comfortable, and our soirce was enlivened by the good humor of one of the guards, who, having seen something of the world, was inclined to make light of the verdant and somewhat peculiar speeches of his more unfortunate fellow-Georgians, who had never before passed the limits of the swamps that surround their dreary homesteads. In the course of this cavalier's yarn-spinning, he told us a good story of an old lady to whom he had applied for bread during the day. It was designed to show her appreciation of General Wheeler. She struck out as follows: "Mr. Wheeler and his critter-company drore into my back yard t'other day, tipped my ashhopper over, and drawed out ten streaks of fight half a mile long, with his 
wagon-guns on the ends of 'em-and when he went away he nerer paid me nary cent. I allers thought you'uns was a decenter set of men, but the Yanks theirselves is no wusser. Now, ef you'uns don't go 'long and leave us what little we've got, we'll surely perish."

\section{"SIIERMAN'S BUMMERS."}

It was no uncommon thing for citizens to dread and detest their own Rebel hordes as heartily as they did the "boys in blue," unless it was "Sherman's bummers," as they were called, whose only business was to vacate pantries and poultry-yards, and to search, with an almost sure prospect of success, for plate, jewelry, and other rich goods, which the people had buried in the pathways and gardens adjoining their dwellings.

Our humorous guard kept us wide awake as long as it was proper, with his well-told anecdotes, and, at times, in spite of our boudage, convulsed the whole party with langhter.

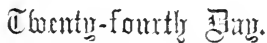

$$
\begin{array}{r}
\text { Srlvania, G., } \\
\text { Monday, December } 19 .
\end{array}
$$

We commenced our march at daybreak, and, after traveling twenty-five miles, halted for the night near Sylvania. This is a small town, and to all appearances of but little importance. It is situated on the Middle Ground Road, midway between Springfield and Waynesboro'. The armies did not halt here; and, consequently, the people knew but little of the sad realities resulting from the devastating tread of armed hosts. 
They were generally disposed to be talkative and friendly. Many of them besieged the guard and prisoners with questions and observations. This was just what we wanted, for the guard could not be vigilant when entertaining citizens.

Early in the erening we were stationed on the porch of a large unoccupied building, and the sen. tinels were posted in front in a semicircular form. It was determined that here we should spend the night.

Soon after halting, the sergeant came to me and said, "My foragers have found some corn-bread and sweet potatoes, which you see at the other end of the porch. I will give you all some potatoes, and keep the bread for the guard." "Very well-rery well," I said, and continued to myself, "If we are permitted to remain outside the building till dark, your guard will get very little of that bread, unless it is issued soon." As he was walking away, I called to him, "Sergeant, liave you any objection to our remaining outside till after supper, as we shall want to use the fire?"

After looking carefully around and hesitating a moment, he answered, "Ye-es, I reckon you can." "Thank you-thank you," I replied; "We will consider it a privilege."

This faror being granted, my mind was set at once on the rampage for a plan of escape, which was soon matured, and which time proved to be successful. 


\section{CHAPTER XVI.}

THE ESCAPE FROM SYLVANIA, GEORGIA.

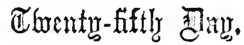

In a Swamp near Srlvania, Ga.,
Tuesday, December 20, 1864 .

Darkness was settling down over the scene last de. scribed, and, though almost completely exhausted by the long march of the day, the prospect of a supper just at hand, and of something even better than "meat and drink" after it, quite relieved me of all weakness, and nerved me for another desperate attempt to escape. The sergeant of the guard had told me that a pile of sweet potatoes was reserved for the prisoners, and so calling the attention of Lientenant J. W. Wright, Tenth Iowa Volunteers, who was then conversing with a citizen, I asked him if it was not time for him to draw his potato rations. At the same time I gave him a significant look, which only prisoners of long experience, like ourselves, could understand, and which he quickly interpreted to mean a change of base. Hastily withdrawing from the citizen, he met me on the porch, where I communicated to him my plan, and inquired if he would join me in its execution. He replied, without hesitation, that he was up to anything but going back to South Carolina, and 
would not shrink from bearing a hand in any moro. which I might make to escape from Rebel cruelty.

Lemon, my long-tried companion, was so peculiarly circumstanced, as to be prevented from participating in this plan, and was taken back to Columbia. I will here say that Wright was also an escaped prisoner from Columbia, whom I had often met during my imprisonment there; he left Columbia a few days after Lemon and myself, but unfortunately, like us, was recaptured at a time when he felt that he was about to bid adieu to the scenes of his suffering.

Finding that "escape on the brain" was Wright's prevailing malady, I lost no time in making what I considered the necessary preliminaries.

I first saw one of the prisoners, who, I had been told by the sergeant, would be allowed to issue the potatoes. I requested him to make the issue upon receiving a certain signal from me, which $I$ made him understand perfectly.

I then asked Wright to step to the end of the porch, near where the corn-bread lay, that was intended for the Rebel guard. I followed immediately after, but was observed by the sergeant, who seemed to wonder at this singular flank movement; he said nothing, however, for we allayed his suspicion of our intentions, by sitting down a entering into conversation. In a moment more a citizen came up, and called his attention from us.

The signal was made, and the half-starved men closed up for their potatoes. It was now quite dark; I hastily took possession of the corn-bread, and taking 


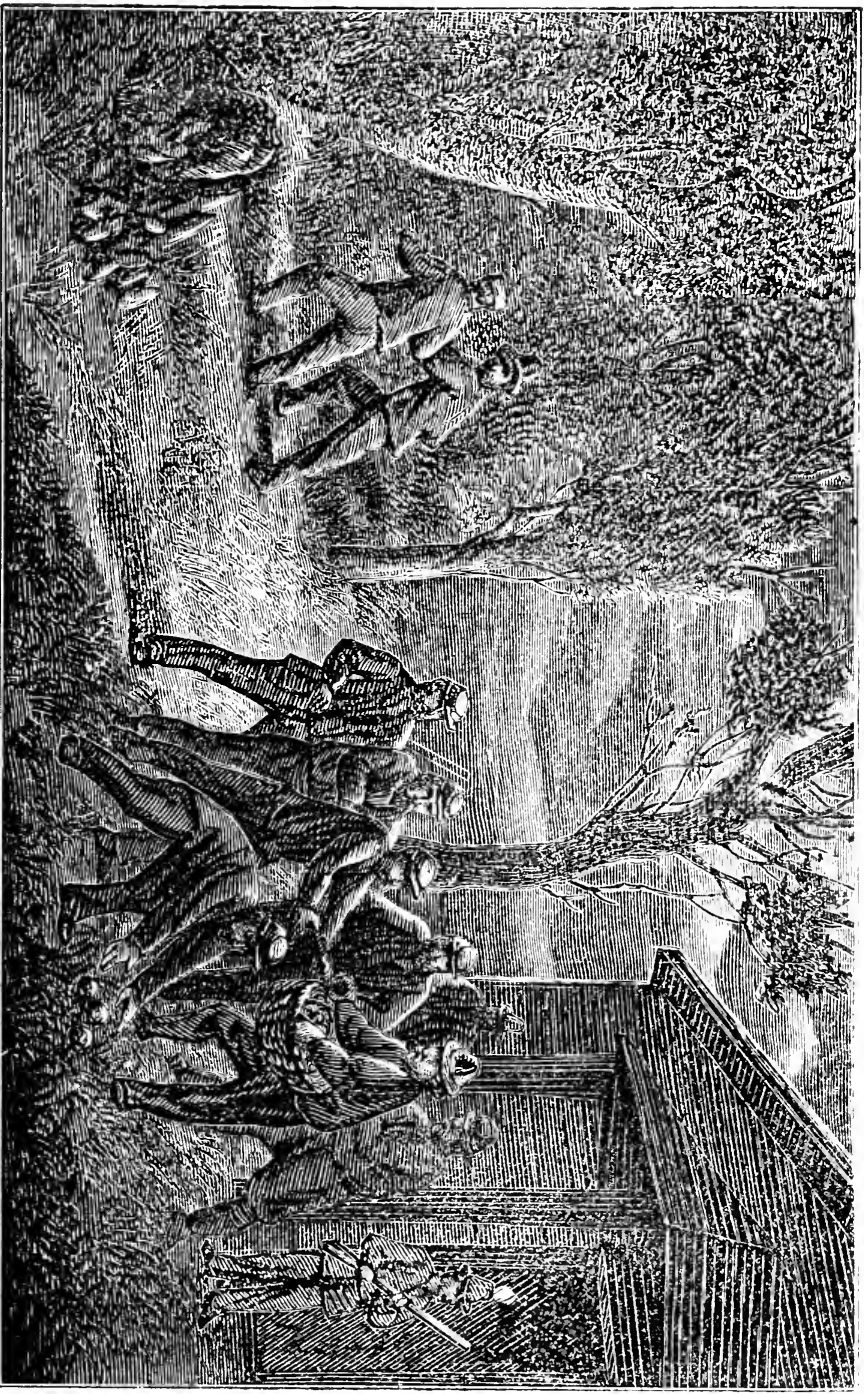



advantage of the crowd, which screened us from the guard, we sloped for a small clump of bushes that were but a few rods distant. Our sudden move was fortunately unnoticed, until after the distribution of the potatoes. Great excitement then prevailed.

The sergeant suddenly arousing himself, exclaimed, "By dog on't, the d-d Yankee officers have done gone, and taken all our corn-bread. I will have them, if it costs me a horse."

Calling out a corporal and four men, he instructed them to proceed to a plantation for hounds, and to bring back the Yanks either dead or alive. He thought it probable that we would take the Springfield road, as that was the nearest route to our lines.

We rrere all this time so near the guard that we could hear distinctly erery word that was spoken, and, as a matter of course, understood the programme perfectly.

We decided with the sergeant, that the route by way of Springfield was unquestionably the one to be preferred; but we did not consider it policy to strike the road when we knew it would soon be patrolled with guards and hounds, and concluded not to be in any hurry until the excitement was over.

As soon as we thought quietness was sufficiently restored to warrant a safe movement, under cover of the darkness and woods, we hurriedly decamped from our place of concealment, and made our way around to the Middle Ground road, over which we had passed but a few hours before under guard. We leaped across it, so as to aroid the suspicion which tracks would very naturally excite, and hastened into a large 
swamp but a short distance from town. While there, we decided upon the course to be pursued, which was recommended by Wright.

The lieutenant had been orer the Middle Ground road before, to within a few miles of Springfield, where he was recaptured; and his experience we considered a valuable possession, as we intended to get back to Springfield as quickly as possible, and then strike for some point on the Sarannah, near which Lemon and I were retaken.

We remained in the swamp until after ten o'clock, when Wright started up and bade me follow. We then went in quest of an old negro hut, where he had before been befriended. It was within a stone's throw of the plantation house, and therefore not safely approached without a thorough reconnoissance.

Secreting me in a corner of the fence which surrounds the plantation, Wright proceeded forthwith to the hut in which he knew

\section{OLD RICHARD}

slept. This was the name of the brave and kindhearted negro, who had supplied him with hoe-cake and bacon, just before lis recapture.

Richard had to consume some time in ecstasies of delight at his opportunity of welcoming again as guest his old friend Massa Wright, whom he had suc. cored during his previous escape, and whom he had the mortification to see pass back toward Sylrania a prisoner in the afternoon.

With all due formality, I was soon introduced to this swarthy descendant of Ham, whose heart was as 
white as his skin was black, and whose warm and hearty shake of the hand convinced me, beyond a doubt, that he was an earnest friend to the Yankee, who would not hesitate to stake his life, if necessary, in an endeavor to further our wishes.

Wright said that he had found a friend, and that I must make arrangements for the "grub." I said to Richard, "We want to leave this place to-morrow night at twelve o'clock, and would like to take four days' rations with us. Can you let us have some bacon and sweet potatoes to put with our cornbread?"

"Pooty hard case, Massa; but dis yer darkey'll do de best he can. Can't get nuffin on dis plantation, but reckon I can buy some tatoes down at Massa Smith's, three miles from yer, and will go down thar after I finish my task to-morrer. As to meat," he said, "you know, Massa, dat in de Souf de slave takes what de white folks frows away; and I reckon you all couldn't eat a tainted ham dat old massa gib me t'other day; but if you can, God knows dis chile gibs it to you wid all his heart."

I gave him to understand that we should be greatly obliged for the described ham; as we had become so entirely oblivious to the sense of taste that we did not stop to question the quality of anything which could be eaten by man.

Having settled the question of rations, we next addressed ourselves to the question of lodgings, and desired Richard to take us to some safe spot, where no Rebel would ever think of coming. Leading the 
way, our colored friend conducted us to a swamp, and found a secure place of concealment in the top of an old pine-tree.

Here we spent the day unmolested and unobserved by any one. The whippoorwill and turtle-dove enlivened the hours with their inspiring notes, and as night began to approach, the gloomy owl from the tree-tops uttered his solemn warning-cry. The pine and cypress, swayed by the breeze, moaned a perpetual chorus, and under their tuition we learned, during the long, dreary hours, how much we were indebted to these dismal wilds, that have concealed alike both friend and foe.

Here the Rebel deserter concealed himself from his pursuers. Here the loyalist found a hiding-place from the Rebel conscripting oficer. Here the trembling negro had his first taste of freedom. Here the escaped prisoner was enabled to baffle blood-hounds and human hounds, and make his way to the Federal lines.

I always considered that a prisoner of war was justified in making his escape, and might claim the consideration due to a human being, even though he were depriving his enemies of the fruits of victory; and it hardly seems possible that in our own free conntry such an one should be tracked with bloodhounds, like a wild beast, and shot down without mercy, like an outlaw.

I cannot help asking, with the poet Whittier,-

"Is this the land our fathers loved,

The freedom which they toiled to win?

Is this the earth whereon they moved?

Are these the grares they slumber in?" 
How wonderfully degenerated have become these unworthy descendants of the mighty fathers of the Revolution. Could their spirits but speak from the heavens, in pitying tones, they would plead with these fiends incarnate, not to stain the pages of history by acts so foul and barbarous that the most unfeeling savage would shrink with horror from their contemplation.

\section{Cwenty-sixth 嫼ay. \\ Between Srlfania and Springfield, Ga., ?
Wednesday, December 21.}

In our eager haste to reach something more congenial than this swamp-life, the hours of the day had seemed to move on leaden wings; but night came at length, and, at the spot agieed upon the night before, near a spring on his master's plantation, Old Richard was found promptly at the appointed hour.

He gave us the tainted meat which has been before described, and a few sweet potatoes. This was the best that he could do for us; and after we had asked God to bless him for his kindness, and told him that we believed the day was not far distant when he would be a free man, we started on our way rejoicing, hoping that we might reach our lines before we should need another supply. We walked about twentyfive miles after leaving Richard, for the most part keeping the road over which we had marched prisoners on our way to Sylvania.

Our progress was necessarily very slow, for, to use an army phrase, I was about "played out," from starvation and long exposure. My weight could not have been more than ninety pounds; though my 
usual weight is about one hundred and forty. Wright was a hardy Western man, much larger than myself, and, besides, he had a good pair of shoes, which are almost indispensable to the success of an escaped prisoner. They were given him by a negro, soon after his escape from Columbia. During the night's tramp he carried me through several swamps on his back, as I was entirely too weak to make my way alone without falling into the slough-holes. Nothing occurred during the night to lessen our chances of reaching Sherman's lines, although at one time we were much startled on seeing two men, who proved to be

\section{REBEL DESERTERS,}

as we ascertained by their conversation. We had barely time to turn from the road and secrete ourselves behind a $\log$, when they passed over the very spot where we had stood but a moment before. It was a bright moonlight night; and had they been looking for Yanks, they could have seen us very readily; but it appeared from their conversation that they were conscripts, and that, not feeling disposed to fight against the defenders of the "old flag," they had deserted from General Wheeler's command, and were making their way back to their homes in Tennessee. We did not renture to hail them, but thinking that for the alleged reasons they were justified in deserting the Rebel ranks, we silently wished them success, and pushed on.

At the break of day we came to a halt in what appeared to be a safe hiding-place, entirely remored from the haunts of men; but broad daylight convin- 
ced us that we were within a few rods of a plantation, where the bustle and noise we heard indicated no little danger. Slyly at first, but rapidly at last, we "got up and dusted." A half-mile heat brought us to a swamp, where, between the roots of an ancient cypress, we found a safe retreat.

During the day our ears were greeted with the boom of heavy cannonading in the direction of Sarannah. We found a twofold pleasure in the sound: first, it indicated that our army was at work, giving Rebellion, as we hoped, its death-blow; and second, it marked the direction of our course, and told us plainly that we were not very far from the friends we longed to meet.

Therentyg-scbently 录an.

$$
\left.\begin{array}{c}
\text { ON OCR TAY, WITII RENEWED OBSTACLES, } \\
\text { Thursday, December } 22 .
\end{array}\right\}
$$

As we knew the moon was not to rise till about midnight, we determined to get an early start and improve the darkness. Accordingly we set out at an early hour, and had not proceeded far, when a plantation became visible before us.

Wright said, "Glazier, if you would like a good supper and something to put in the haversack, I will tell you how you can make a raise on a safe scale, by just representing yourself to be a Rebel, and trusting to your face."

It was certainly not advisable to neglect such an opportunity of replenishing our commissary supplies, and I requested him to state the particulars. He replied that he had been credibly informed, that the plantation house, towards which we were directing 
our eyes, was occupied by a planter's wife and some small children, whose husband and father was in the Rebel army. He had also learned that there were no hounds on the place.

\section{INTERVIEW WITH MRS. KEYTON.}

After hearing the details, and having agreed upon signals of danger, should any oceur, I started on my foraging expedition with a good degree of assurance of success.

Stepping up to the door of the mansion, I rapped, and a very intelligent lady soon made her appearance. I asked, "Can you give this Rebel a supper?" She replied, "You shall have the best the house affords," and invited me to step in and take a seat by the fire. I did so, saying, as I took my seat, "Madam, I am shocked at the dastardly conduct of General Sherman in his march through Georgia. It has been characterized by nothing but what should excite the rerenge, and more to action, every man possessing a true southern spirit. Our aged citizens, who have banded together for mutual protection, hare been treated as bushwhackers-have been driven from their homes, and their property confiscated. Our hounds, always true to the interests of the South, have been shot down by the roadside for no other reason than that they were used in tracking escaped prisoners__-

Interrupting me here, the lady remarked, much to my surprise, that she could not see that the Yankees were much worse than the Confederates, after all. She said :

"When the Yankee army passed through the 
State, they took from the rich the supplies necessary for their sustenance; and when om cavalry followed in the rear they took nearly all that was left, seeming to care but little for our wants, often stripping defenceless women and children of their last morsel of bread."

"I regret, madam, that the conduct of our troops has been such as to give you reasons for complaint."

"I, too, regret that our men have not proved themselves worthy of a cause which they appear so willing to defend."

"Remember," I continued, "that our commissary department has been completely wrecked, and that we are entirely dependent upon the people for the subsistence of a large army."

By the sad expression of her countenance, which accompanied and followed this remark, I saw clearly that she felt we had reached a crisis in the war, when Providence was

TURNING THE TABLES,

and she accordingly interrogated,

"And what do you think of present prospects?"

I quickly responded, "Our future looks dark, our cause appears almost hopeless, but the sacrifices of our gallant dead remain unavenged. Therefore, 'we must fight while there is a man left, and die in the last ditch.",

"If there be no longer any hope of success, sir, I should say that it rould be better to lay down our arms at once, and go back under the old flag."

"We must fight, Madam, we must fight."

"But it is wickedness and worse than madness to 
continue this arful massacre of human beings, with. out some prospect of ultimate success."

"Very true; but we have lost all in this struggle, and must sell our lives as dearly as possible."

By this time the good lady seemed to have waxed as enthusiastic and warm as the fire orer which the servant was preparing my supper, and she added:

"My husband is a captain in the Twenty-fifth Georgia Infantry. He is the father of these children, and is very dear to both them and me. Long have I prayed that he might be spared to return to his family, but fear that we shall nerer be permitted to see him again. When he entered the army I admired his patriotism, and was glad to see him go in defence of what I supposed to be the true policy of the southern people; but we have been deceived from the beginning by our military and political leaders. It is time to open our eyes, and see what obstinacy has brought us. We are conquered. Let us return to the administration of the Federal government, ere we are ruined."

"Madam, your sympathies appear to be largely with the Yankees."

"It is not strange, sir; I was born and educated in New England;-and your speech would indicate that you too are not a native of the South."

"You are right; I am a New Yorker by birth, but have been for a long time in South Carolina."

After partaking of the frugal meal set before me, which consisted of corn-bread and sweet potatoes, I thanked the lady for her lindness, and told her that I regretted very deeply that I was not in a situation 
to remunerate her for so much trouble. Noticing my blue pants as I arose from the table, she obscrved: "It is impossible for me to know our men from the Yankees by the uniform; but a few days since, two solcliers asked me to get them some supper, claining to be scouts to General Wheeler; they told many very plausible stories, and the next day, to my astonishment, I was charged with harboring Yankee spies."

"I do not wonder that you find it difficult to distinguish the Confederate from the Yankee soldier, for in these trying times a poor Rebel is compelled to wear any thing he can get. The dead are always stripped, and at this season of the year, we tind the Federal uniform far more comfortable than our own."

"It must be an awful extremity that could tempt men to strip the dying and the dead."

"We have become so much accustomed to such practices, that we are unmoved by scenes which might appall and sicken those who have never served in our ranks."

"I sincerely hope that these murderous practices will soon be at an end."

Feeling that $I$ had been absent from my companion long enough, and that it was time to make my departure, I arose, saying,

"I must go, madam; may I know to whom I am so much indebted for my supper and kind entertainment this evening?"

"Mrs. James Keyton. And what may I call your name?"

"Willard Glazier, Fifty-third Alabama Mounted Infantry." 
"Should you chance to meet the Twenty-fifth Georgia, please inquire for Captain Keyton, and say to him that his wife and children are well, and send their love."

"He shall certainly have your message if it is my good fortune to find him out. Good-night."

The interview with Mrs. Keyton ended, which zeemed to convince her that I was a bitter Rebel, I hastened out to receive the congratulations of $W$ right upon my success, but found him in rery bad humor, as he was entirely out of patience with waiting so long for my return. I explained to him the reason of the delay, but all to no purpose, for he was so provoked that he would not listen; and thus feeling a little angry at each other, we mored toward Springfield.

We were determined not to pass this important post without gaining some information about the strength, position, and intended morements of the Rebel forces in General Sherman's rear. This required cantious mancurring, and some daring. But what we gained well repaid us for our risks.

We found General Irerson's headquarters to be at that place, and were at one time within about fifteen paces of the house which he occupied.

We were so near his prorost-guard as to hear distinctly every word that was spolien. They were discussing present prospects, and the news which they had received the day before of the fall of Savannah. It seemed to be the prerailing opinion that the ConPederate army was about "played out," and that s.oner or later ill-fated Dixie would be compelled 
to submit to the tyrannical rule of the invader. One tall, gaunt-looking fellow, who appeared to be mouth-piece for a large number, straightened himself up in front of a fire, around which a group had gathered, and burst forth as follows: "By dog on't, the $d-d$ blue-bellies have got ahead of we'uns on this 'ere tramp." I could not help thinking what a change had taken place in their views since the seventeenth, when we were prisoners at Wheeler's headquarters, for at that time they asserted that they had

\section{"SHERMAN JUST WHERE THEY WANTED HIM."}

Now their victim is evidently in the ascendant, and the army that was to sacrifice its chivalrous blood in the defences of Savannah, seeks safety in flight, having abandoned its artillery and supplies. Such information, from such a source, was not at all disheartening to us, and we left Springfield with renewed courage.

It was our intention to strike the Savannah River road near Helmy, where we supposed was stationed the enemy's out-post. Wright knew nothing about this route, and left the planning all to me, as I was more familiar with the ground.

It was by no means an easy task to pursue any direct course in this swampy country, intersected as it is by blind roads. The sun, moon, and stars, were our guides; and it was to them that we were chiefly indebted for our success thus far.

While in South Carolina and Northern Georgia, we depended largely upon the negroes for guidance: 
but tice passage of our army through this section of the State opened the way to freedom, and invited the bondman to cast off his shackles, and enjoy the blessings of liberty.

Strange as it may seem, nearly every slave had embraced the opportunity presented him, and very quietly taken leave of his kind old master without waiting for ceremony. I say strange, for the simple reason, that it has been the boast of the Southerner that the slave would not exchange his chains for freedom; that he was happy when governed by a kind master, and rould not seek to better his condition by a cliange.

Having distanced Springfield about six miles, we found daylight approaching, and hurriedly turned from the road which we had been following for more than an hour, and secreted ourselves in some tall swamp-grass. Here we had rested little more than an hour, when we were suddenly

\section{STARTLED BY HOUNDS.}

Wright turned to me and said, "We are followed."

I asked, "What do you propose to do?"

"I am undecided," was his reply.

"It is my opinion," I said, " that there is no time for reflection. If we are not off at once, we will be prisoners before leaving this swamp."

"Well, off it is, then," said Wright ; and jumping into our shoes, which we had taken off in order to dry our feet, we got out of the swamp in doublequick time, crossed the road, and, taking the sun for a guide, struck a south-easterly course, leaping 
fences and ditches, fording streams, and passing through thickets, that would greatly retard the progress of the bushwhackers in pursuit.

The chase continued until about one o'clock. The hounds, for the most part, were so near that we could hear their yelping distinctly, when, fortunately, we came to a large creek. Jumping into the stream, we followed the current fifty or sixty rods, and then again resumed the course we intended to pursue. This precaution must have foiled our pursuers, for we had not proceeded far before we became fully satisfied that the bushwhackers and hounds had been outgeneralled. We did not halt, however, but continued on towards the " promised land." Greatly encouraged by our success since morning, we became so indiscreet and reckless as to venture into open fields whenever they happened to be in our line of march.

\section{A NARROW ESCAPE.}

About two o'clock P. s., just as we were clearing the outskirts of a swamp, I was surprised to see my companion drop suddenly behind a large cypress, without uttering a word. I followed his example, not deeming it prudent to ask a question.

I watched the movements of Wright, who, after remaining motionless a few moments, raised his head and looked to the front. Falling back behind the aged tree, he whispered, "Did you see the picket?" I answered, "No;" but looking up, saw that we were within a few rods of armed men.

No further observations were neccssary to convince us that the sooner we were out of such quarters 
the better. We had not time to move, however, before a cavalry patrol came up to visit the post, and tc give new instructions. As soon as the patrol had passed, we crawled upon our hands and knees into the swamp, keeping behind a clump of large trees that screened us from the picket.

Having reached a dry spot, we halted and debated the question of going farther or remaining where we were. There was certainly great danger of detection if we attempted to leave the place, and Wright decided that our true policy was to remain. I had a contrary opinion. I was so wet and cold that the thought of confining myself to such limited quarters made me not a little uneasy; for we could neither stand up nor lie down. Our clothes too were wet, the weather extremely cold, and we had not slept in forty-eight hours; and then, too, the idea of sitting up like a pair of mummies five hours! I told Wright the thing was not to be thought of, and that I would strike out for better quarters, though risking my liberty.

As he preferred to remain I set off without him. The dangerous point was passed, by watching the picket and making good time when their backs were turned.

Getting out of the swamp, I went in quest of a favorable haunt where I might lay my weary limbs and dry my clothes.

I was delighted as well as amused to find that Wright was close upon my heels, glad enough tc abandon the sitting posture for something more agreeable. I welcomed him to my new place of conceal 
ment, where we spent the afternoon unmolested. However, we were not far firom the picket, and in. clined to think that it was their outpost.

\section{AN AMUSING INCIDENT}

occurred this evening a few minutes after sunset. The weather being extremely cold, and our clothes still damp, we thought that a small fire would be very pleasant; and, suiting the action to the word, dug a hole in the ground, gathered some pine knots and started a blaze, which in my judgment could not have been seen by any one at a distance of fifty feet, but, to my companion, it appeared to be of gigantic proportions; and his imagination became so much excited, that he set one of his feet upon it, and thus put an end both to my enjoyment and the fire.

I was disposed to be angry, but thinking it not best to challenge a recapture by loud words, " nursed my wrath to keep it warm."

These little differences of opinion are things to laugh at after the danger is over, but then they might have proved serious. It is next to impossible for two men to travel under such circumstances without more or less of disagreement; for when a man considers that his life may depend upon some thoughtless act of his companion, he is disposed to adopt energetic measures.

We congratulated ourselves very much on having escaped the pursuit of the hounds. It is a difficult matter to elude them, as their scent is very accurate.

Indeed, this is never accomplished, unless some. thing is rubbed under the feet, which we learned from 
the negroes, but having had no opportunity to use the antidote, I have forgotten what it was.

It is probably already understood by the reader that a stream of water would also check their efforts. These things were among the first lessons ever given us by our colored friends and guides. There are two kinds of hounds, blood-hounds and baying hounds. The baying or yelping hounds take the lead, and are followed by the blood-hounds, which make little noise.

These yelping curs will not come nearer to a person than four or five rods, but will cut circles, and thus mark their locality until the blood-hounds or planters come up.

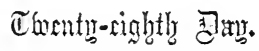

$$
\left.\begin{array}{l}
\text { SarAXXAII, GA., } \\
\text { idas, December } 23 .
\end{array}\right\}
$$

This, I think, was the happiest day of my life, and one that will ever remain as a bright oasis in the desert of the past.

But I must not anticipate too much in my story, for in my last record we were still in Secessia, and within a few rods of a Rebel picket.

With the last gleams of the twilight, we succeeded in flanking the Rebel sentries, and luckily, we soon found a colored friend, who was familiarly known among his acquaintances as

\section{" UNCLE PHILIP."}

On making known to him our true character, he informed us that we had passed the Rebel outposts, and that the Yankees had possession of Cherokee Hill, on the Sarannah River road, only eight miles 
from his cabin. Our joy was inexpressible, for it seemed as though no more glorious tidings ever saluted mortal ear's.

We asked our kind informant if he could guide us to our lines. He replied, "I'ze neber ben down dar, massa, sense Massa Sherman's company went to Sa. vannah; but I reckon you' uns can git massa Jones, a free cullerd man, to take you ober. He's a mighty bright pusson, and understands de swamps jest like a book." Calling at Mr. Jones' hut, we learned from his wife that he was out on a scout, but would be in by eleven o'clock. She assured us that he was ever glad to do all in his power for the Yankees, and asked us to come into the hut and await his return. We very reluctantly complied with her invitation, fearing that

\section{REBEL SCOUTS}

might venture down between the lines, and thus blast our brilliant prospects.

Mrs. Jones, however, was by no means a dull tactician, and offered her two sons, one a lad of eight years, and the other six, for outpost duty.

I divided the command and posted the pickets, stationing the oldest boy in the road, at a distance of twenty rods from the cabin, and used the other for patrol, who was to keep a sharp lookout; and, in case any one might be seen approaching the post, was to notify his mother, thereby giving her an opportunity to conceal us.

This matter attended to, a generous supply of hoecake and parched corn delighted our eyes; for Auntie was not long in appeasing our hunger with the best 
her humble cot afforded. Jones came in at the mentioned hour, but did not think himself sufficiently well acquainted with the safest route to warrant his acting in the capacity of guide; but, like all other negroes that I have met in the South, he very readily called to mind one who, he thought, would accompany us, and whom he could recommend very highly as an active and intelligent follow.

Securing a small piece of fat pine for a torch to light our way through an intervening swamp, we started for the Savannah River road, beyond which the negro could be found whose many good qualities had been pointed out to myself and companion. Much to our astonishment and chagrin, colored man No. 2 was not so well posted as the man who recommended him; but luckily, and much to our delight, he very promptly referred to another negro, who had come up from our lines the same morning, and who, doubtless, would be glad to return with us. The vegro last recommended bore the name of

\section{"MARCH DASHER."}

We found him to be a genuine Ethiopian, as black as any colored individual I have ever met; and as dignified and derout as he was active and swarthy. Upon being asked if he could show us the way to Clierokee Hill, he replied, "I'll do it, massa, if God be my helper."

We desired to start at once, but could not persuade him to move before daylight. He said, "Dis chile knows whar de pickets is in de day time, but knows nuffin 'bout 'em arter dark." Several at- 
tempts were made to induce us to remain in the hut till morning; but no amount of safety insurances could persuade us to take such an apparently inconsiderate step.

The idea that it would not be policy to move on before morning inclined us to think that our landlord might be treacherous, and we were not a little uneasy until prayer was offered for our benefit, when we became fully satisfied that we could at least repose confidence in his fidelity. As soon as prayers were concluded, we betook ourselves to a pine thicket, determined to give "March" no peace until he should set off with us.

\section{THE NEGRO'S CLOCK NEEDS NO REPAIRING.}

At about one o'clock in the morning, Wright turned out and told him that day had just begun to break. He got up, came to the door, looked for the seven stars, and then remarked, in a very good-humored way, "I reck'n it's good many hours yet till break ob day, massa. Yer can't fool March on de time; his clock neber breaks down. It's jest right ebery time." Feeling somewhat chagrined at his ill success, Wright returned to the thicket, saying, "Glazier, there is no use of being in a sweat; for you might as well undertake to move a mountain as to get the start of that colored individial." We made no further attempts to dupe our guide, but very impatiently awaited his call. He came to our place of concealment at the first peep of day, and said, "Gemmen, now I'ze ready to take you right plum into Mr. Sherman's company by 'sun up.'" We followed him 
without ceremony; and just as old Sol began to tint the hill-sides with his first rays, we saw, with unbounded joy,

\section{A GROUP OF BLUE COATS}

watching very eagerly our approach; for it was the Federal outpost. At first, we were undoubtedly regarded as enemies, but, by taking off our hats and making friendly signs, their suspicions were allayed, and they beckoned ns to come on.

After convincing them that we were not Rebel deserters, a most cordial reception was given us by the picket, which proved to be a detail from the One Hundred and First Illinois Volunteers, Twentieth Army Corps.

Each man took us by the hand, congratulating us for our erentful and successful escape, while we cheered the boys for the glorions work they had accomplished for the Union. Haversacks were opened, and placed at our disposal. There was a great demand for hard tack and coffee; but the beauty of it all was, Major Turner was not there, to say what he has often repeated, "Reduce their rations; I'll teach the $d-d$ scoundrels not to attempt an escape."

I cannot soon forget the sea of emotion that wellnigh overwhelmed me, as soon as I could realize the fact that I was no longer a prisoner, and especially when I beheld the "starry banner" floating triumphantly over the invincible reterans, who had followed their "Great General" down to the sea. 


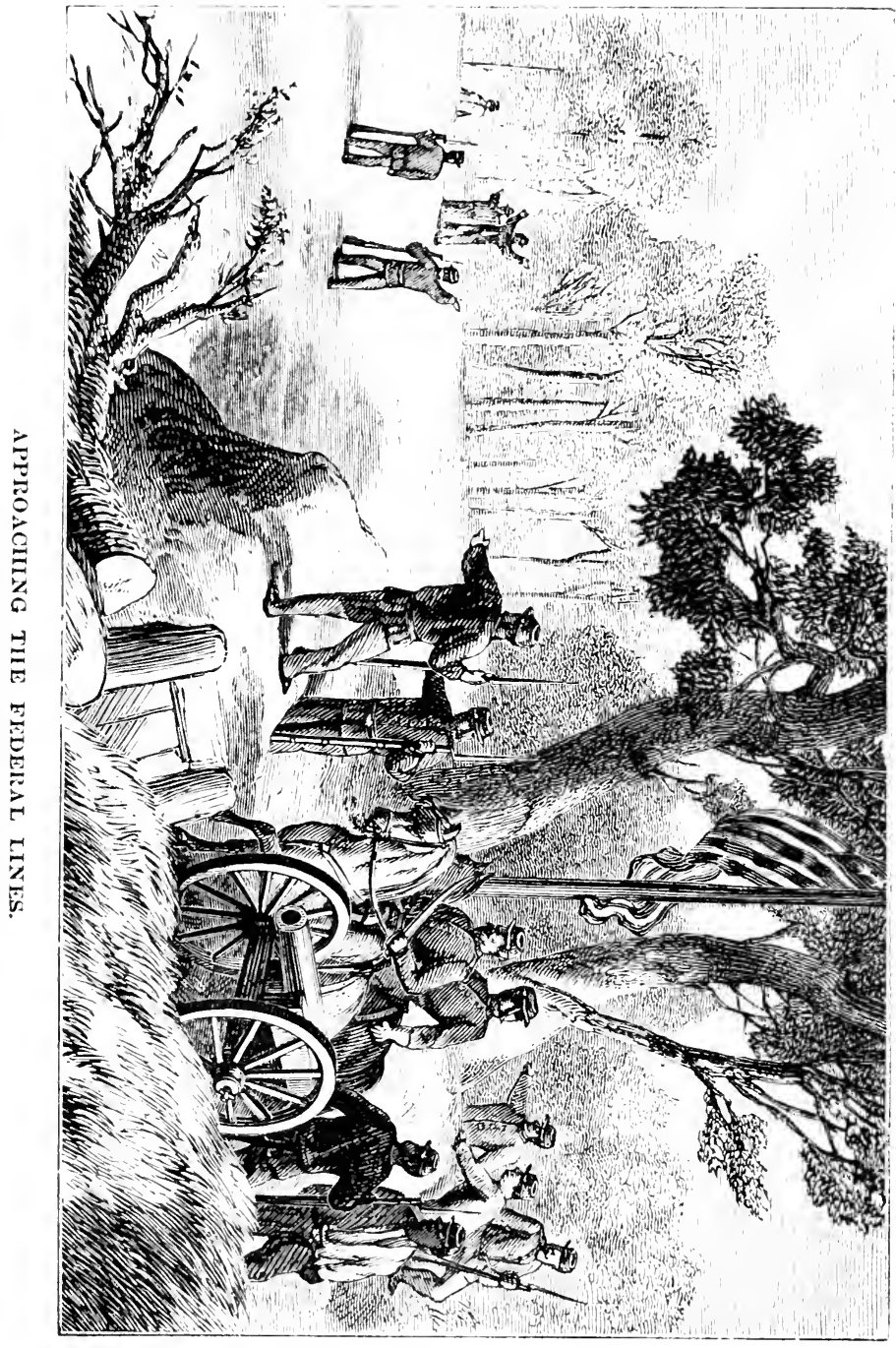





\section{CHAPTER XVII.}

HOMEWARD BOUND.

Savaniah, Ga., December 24, 1864.

Oun breakfast at the picket-post was seasoned not only with hunger, but by many a bon mot from my companion and our new-found friends. This concluded, we were sent into the recently-captured city with a brigade of the Twentieth Army Corps, which formed a part of Sherman's rear-guard.

Wright and I were objects of general curiosity and conversation. It would have been a difficult matter, even for intimate friends, to have identified us in our motley uniforms. I was clad in a coat of southern gray, with blue pants, a bewitched-looking hat, which shed rain in the centre of the crown quite as well as at the rim, and an old gray blanket, which for months had answered the double purpose of bed and beddinm My feet were harnessed into the opossum-skin shoes before described, the gift of black, but faithful, hands. Our long marches orer the sandy roads, and through the muddy swamps, had quite worn them out, so that through many a broken place my toes protruded, like a turtle's head between irs shells.

My haversack was a curiosity in its ray, being composed of an old towel, which was sewed up by lemon many weeks before. Said haversack had 
borne its journey well, but now showed unmistakable signs of demoralization. Sweet potatoes, unless of a fabulous size, slipped through it as readily as money through a soldier's fingers; and large must have been the loaf which could retain quarters within its awful depths. I would be glad to give Wright the opportunity to describe our appearance, but having had the impudence to look better than myself, he does not deserre the place.

Our journey to the city was rendered exceedingly pleasant and agreeable by our friends. Two officers, whose names I have been so ungrateful as to forget, kindly offered us their horses, and dismounted for our convenience. This offer was the more gratefully accepted, as we were both very much exhansted, Wright having carried me for several miles during the few last days of our escape. We found, too, that while we were within the enemy's lines, the raging fever of excitement nourished our strength, and wonderfully increased our power of endurance. But with this strain upon our natures remored, a weakening and almost painful relaxation ensued.

On reaching the city, our first inquiry was for Wright's old regiment; but it was almost like searching for a pin in a hay-rick in the dark. The unsettled and constantly-moving condition of the army, made it difficult to ascertain the location of any particular brigade eren, much more so, that of a regiment.

All this time we were comparatively as strangers among friends, having found no one who could iden. 
tify us, and hence we were without official recognition. This made it necessary for the authorities to keep us under guard, as they knew not whether we were what we represented ourselves to be, or, per haps, spies or desperadoes. Such treatment seemed hard at first; but when we reflected upon our checkered costume and suspicious appearance, we could find no fault, and readily yiclded obedience to our superiors.

Haring played the Rebel so long, we ourselres had our allegiance slightly mixed, but by a deal of recollecting and protesting, we came at length to convince ourselves, and the authorities also, that some time, away back in the past, we had been Union men, and belonged to the Federal army.

This glorious truth was established beyond a doubt, when, after going from headquarters to headquarters, we were at last brought among Wright's old companions. His reception was almost equal to Cæsar's triumph in Rome, after his brilliant campaigu in Northern Africa.

At night we were entertained by Captain A. L. Swallow, commanding Wright's company. Being a man of noble nature, he ministered to our wants like a father. Indeed, as our circumstances became known, erery one seemed anxious to do us a favor, and no pains were spared to make us comfortable and happy. Suitable clothing was soon given us, and we began to appear like civilized persons. Our sojourn in camp or town was a continuation of fête days, which at times quite bewildered me. "There are moments in our lives," writes an old prison com. 
panion," "the recollection of which possesses all the unsubstantial qualities of a dream.

"The first days of liberation after a protracted captivity are reiled in the misty atmosphere of unreality."

And thus it was with me. I could scarcely recognize the identity of my own being. Was I the same man, who once shivered with cold, and nearly died of liunger, in a Rebel Prison Pen? Could it be I that wandered nude and forlorn, through swamps and streams, mid snakes, alligators, hounds, and murderous men, and for one long month suffered the privations of a fugitive? As I took a retrospect of those days, it seemed as though I had trarersed the impassable gulf, the dreadful chasm of a dream,-but at length I became convinced that I was I myself, and that what I enjoyed was substantial and positive Freedoxi ! The greater part of

\section{CHRISTILAS DAY}

I spent in the city. I partook of a sumptuous dinner with Mr. H. Brown, whose residence was on Congress street, opposite the Pulaski House. Mr. Brown was known as a firm Union man, and although he had suffered much from adherence to his principles, and frequently been stripped of his goods, he still remained true to the old flag and the government of his fathers. So far as I could learn, Sarannah contained more of this class of men than any other southern city.

Lieutenant E. H. Fales, who was a fellow-prisoner

* Lieutenant-Colonel F. F. Cavada. 
at Charleston, was found secreted at Mr. Brown's house when our army entered Savannah. The lieutenant was in the city for more than a month, representing himself as a very innocent foreigner, but was at one time conscripted and ordered on the defenses.

\section{At Kilpatrick's HeAdQUARTERs, \\ December 15}

Lieutenant Fales and myself procured horses from the quartermaster of the Twentieth Corps, and rode out to Kilpatrick's headquarters in the afternoon, my object being to secure identification by General Kilpatrick, in order to obtain transportation North, as he was the only officer in the department who knew me to have been in the United States service previous to my capture. The general received us with his accustomed urbanity, and kindly furnished me with the necessary documents, in the absence of which I had becn detained from going North.

After the arrangement of this business, the gencral, and Captain Estes of his staff, invited us to a generous supper, during which they were much interested in my account of prison-life and escapes. One hardly likes to be the hero of his own tales, but modesty was no plea for silence under the circumstances.

My term of serrice having expired, I was very anxions to get home to my friends, whom I had not seen for many months. But the unsettled state of the army made delays mavoidable, and I was forced to abide my time. 
$\left.\begin{array}{r}\text { Aboard Steamship "Planter," } \\ \text { December } 29 .\end{array}\right\}$

Lieutenant Fales and myself took passage on the steamship "Planter" early this evening. Wright's term of service having expired, he remained at Savannah to be mustered out, where I bade him an earnest farewell.

The captain of our vessel was none other than the negro pilot, who, by a daring exploit, had saved himself and his craft to the Union, by running her out of Charleston harbor, and joining our blockading squadron. He was accordingly made commander of the converted "Planter," and was a "colored person" of some consequence. One of our officers going on board, mistook him for the boot-black, and sang out, "Hello, cutfee, black my boots?"

The dusky captain turned, with a look of ds sdain, and answered, "I dun no nuffin 'bout boot blac'kin'. I commands dis craf, I is."

At the time of our passage she was ruming, in Gorernment employ, as far as the obstructions at the mouth of the Sarannah river, where she transferred her cargo and returned. There was a channel through these obstructions, and but few pilots could take a ressel through them.

Only a few days after the capture of the city, a blockade-runner, fresh from Manchester, England, in happy ignorance of the result, carefully dodged our vessels, which just as carefully kept unt of the way, and gare a clear passare into the harbor. She was fast to the dock before the mistake was discorered, when her commander was arrested, and her cargo confiscated. 


$$
\left.\begin{array}{c}
\text { Aboard Steamship "Asmland," off Hilton Head, } \\
\text { December } 30 .
\end{array}\right\}
$$

During the night, we were transferred from the "Planter" to the "Delaware," and reached Hilton Head, South Carolina, in the afternoon, where we went aboard the steamer "Ashland," for the Empire State —God bless her dear old name !-Many a poor fellow who started out with us will never again press her soil, nor be welcomed home by those who are anxiously awaiting his return.

The "Ashland" is a small ocean steamer, and was commanded by Thomas Cowdry, an old sea captain, weather-beaten and brave. His genial entertainment of the passengers, and his thrilling tales of life "on the ocean wave," cannot soon be forgotten.

$$
\left.\begin{array}{c}
\text { IN a GaLE off CaPe HatTeras, } \\
\text { January 2, } 1865 .
\end{array}\right\}
$$

We had a rough holiday yesterday, in the midst of a terrible gale, which threatened us with disaster. All the passengers had a taste of sea-sickness, as well also as a large part of the crew, save those directly connected with the management of the vessel. This being my first experience with old Nepture, my case was none of the mildest.

The pen of inspiration has most graphically described such a scene as this.

"They that go down to the sea in ships, that do business in the great waters;

"These see the works of the Lord, and His wonders in the deep.

"For he commandeth, and raiseth the stormy wind, which lifteth up the wares thereof. 
They mount up to the heavens, they go down agram to the depths: their soul is melted because of trouble.

"They reel to and fro, and stagger like a drunken nan, and are at their wit's end.

"Then they cry unto the Lord in their trouble, and He bringeth them out of their distresses.

"He maketh the storm a calm, so that the waves thereof are still."

During the worst bellowing of the tempest, the captain comforted us all he could by expatiating on the strength of his vessel, and pointing out her beauties in a manner quite mistifying to a landsman. The fact that she had weathered many a severe storm before gave us much confidence, and at length, sereral passengers, recalling the very appropriate Sunday School song, struck out with the verse,

"Wildly the storm sweeps us on as it roarsWe're homeward bound;

Look, yonder lie the bright hearenly shores,

We're homeward bound;

Steady, Ob pilot, stand firm at the wheel! Steady! we soon shall outweather the gale;

Oh how we fly 'neath the loud-creaking sail-

We're homeward bound."

NeW York, January 4.

At length, about twelve o'clock at night, our vessel grated along the wharf of the metropolis, and I awoke to the glorious realization that I was again breathing the air of my native State. There was an exhilarating rapture in the thought, which I can nerer express, and fixed that moment as a golden era in $\mathrm{my}$ 
memory. I hope never to become so hardened that that patriotic and Christian exultation will ever be an unpleasant recollection.

And with many a brave and fondly-cherished comrade,-and with thousands whose faces I never knew, but whose sufferings I shared,-I can sing: "Now our prison life is orer! Ah! it is a pleasant thought, And we here await our furloughs, ere again our homes are sought.

Farewell South, and all thy dead lines! Farewell traitors, robbers too!

Cherished friends of youth and childhood, we are coming home to you!

And will not your smiles of welcome half repay our griefs and cares,

When once more you see us sitting in the old familiar chairs? But there's One who reigns above us-we should give our thanks to him,

For the bright hopes in the bosoms, where sweet hope, alas! was dim,

For his kind and loving presence, that at last we lived to stand,

Free from prison life in Dixie, in our own beloved and loyal land.

Let us pray for peace forever, for the Union glad and free, With a tear for comrades faithful, whom we never more shall see.

Ever trusting Him above us, though the clouds may gather fast,

Knowing well our Father's mansion will receive us at the last." 


\section{CHAPTER XVIII.}

[I append to these records the following selections from the files of the Weekly Journal, which was published or read to the prisoners at Libby Prison In the autumn of 1863, by the Rev. Louis N. Boudrye, late Chaplain Fifth New York Cavalry. They may serve to illustrate more clearly than it has been done in the body of the work the tout ensemble of that dark period in the hietory of thousands of our soldiers.]

\section{The Libby Chronicle. DETOTED TO FACTS AND FUN.}

Vol. I.] Libby Prison, Richmond, Va., August 21st, 1863.

[No. I.

Prospectus. *

The Libby Chronicle will be issued weekly, from Prisoner \& Co.'s steam press of thought. Such will be the equalization of labor among those engaged in the enterprise, that this publication can be afforded at very low rates. Price of subscription, weekly, one moment's good attention, invariably in advance. These terms being complied with, the paper will be forwarded postage free.

With such facilities before the public for obtaining useful knowledge, it is needless to state that we expect an extensive patronage. Our adherence to facts,

* Eight numbers of the Chronicle were issued. 
which are always the most stubborn arguments, and to the motto that

\section{" $\Lambda$ little nonsense now and then, \\ Is relished by the wisest men,"}

is a full guarantee to our patrons that they will ever obtain an ample equivalent for their subscription price. We cannot very well forbear mentioning that the contributors to our columns are among the most eminent of the land, including the skillful lawyer, the sedate judge, the erudite priest, the amusing comedian, the renowned legislator, and scores of others from the various walks of life, whose connection with our periodical places success beyond a doubt.

As we make our humble bow to the public, we hope that progress may mark our course in every department of our work, until the Libby Chronicle, its editor and publisher, its friends and patrons, will find themselves sailing toward the North Land of liberty and civilization.

\section{Kansas Brigade's Version of John Brown.}

John Brown's body lies mouldering in the grave, While weep the sons of bondage whom he ventured all to save, And though he lost his life in struggling for the slave,

His soul is marching on.-CHоrбs.

John Brown was a hero, undaunted, true, and brare, Kansas knew his valor when he fought her rights to save, And though the grass grows green above his northern grave,

His soul is marching on.-Crrores.

He captured Harper's Ferry with his nineteen men so few, And frightened "Old Virginny" till she trembled through and through ;

They hung him for a traitor--themselves a traitor crew,

But his soul is marching on.--CHores. 
The conflict that he heralded he looks from heaven to view, On the arny of the Union with her flag, red, white, and blue, And heasen shall 1 ing with anthems o'er the deeds we mean to do.

As we go marching on-CHores.

O soldiers of Columbia, then strike, while strike you may, The death-blow of oppression in this better time and way, And the dawn of old John Brown will brighten into day,

As we go marching on.-CHores.

Captain.

"Solth Window," Libby Prison, Richuond, Va. No. 1.

MLr. Editor: Who among your hearers hare not felt as the writer feels to-day, weary and worn out with the dull monotony of prison life? There is no future here; night and day succeed one another with but the same scene, the same fruitless longing for liberty. Even these more than precious letters, brief mementos of the dear ones at home, make the bitterness of captivity but the deeper. Many, if not all of us, have faced death on the battle field and are willing to do so in our Country's cause again; but who, once released, would yield to see the walls of Libby Prison once more? True, that some hare been unfortunate enough to now be prisoners of war a second, and, in one instance, we beliere, a third time,such are entitled to our sympathy. They are indeed sufferers.

Am I harping, Mr. Editor, on a threadbare theme? I crave pardon. A fit of the blues is on me to-day, and what I write partakes of it. Even the heavens are orercast with clouds. 
"The autumn dass have come, The saddest of the year.--"

We take a sidelong glance from our "south win. dow," and see away off in the distance a portion of Belle Isle, occupied by thousands of our brave men. Poor fellows! Their lot is, while it lasts, even worse than ours.-

Hark, what sound breaks from the depths below our feet? "Mess No. _- dinner." We go, Mr. Editor, we go. Sorrowfully we lay our pen aside, hoping when we write again, to reach a more cheerful result.

Au revoir. Black bean soup awaits us.

\section{Captann P.}

\section{Conundrums.}

Q. In what respect do the officers confined in Libby resemble Dives in the parable?

Ans. They are looking to Abraham for comfort.

Q. Why is an elephant like a pile of brick?

Ans. Because neither can climb a tree.

Q. Why is our soup in Libby like the stuff of which dreams are made?

Ans. Because it is a body without substance.

\section{Castle Thunder.}

\section{PART I.}

Ox Cary street, in Richmond, there is a mongrel den Of thieres, sneaks, and cowards, mixed up with gentlemen. $\mathrm{Oh}$, it is a shame to huddle in together Men and beasts, wild and tame, like birds of every feather. 
The Reb. authorities scared up this living wonder, Made it a prison, and named it Castle Thunder. Here they tumble in characters of every hue, Reprobates steeped in sin with the Christian and the Jew.

Conscripts by the dozen, at daylight and after dark, Come pouring in the Castle like animals in the ark; Some are small, some are great, some show pluck, some white. liver.

Some from Mississippi State and "Goobers" from Tar River. Substitutes and deserters come in in sorry plight, And sub-gents, too, are here quartered for the night. Blockade runners, also, are shut up for a warning, But seldom leave, as promised, early the next morning. While on Potomac's banks both parties try to nab 'em, If they escape the Yanks, old Jeff. is sure to grab 'em.

So-called spies are castled here, who think it real hard luck, They are all from Yankeedom, excepting one Kennuck; Disloyalists are also here, and one for being a guide, The boys call him Doodlebug, for piloting Burnside. We also have an oyster man, who, the officers discover, Was Union on the York but Secesh on James River. Part first tells you where the Castle is and who are there, Part second will disclose the manner of our fare.

\section{PART II.}

Te have a dozen rooms or more, and in some two or three, The boys wear handcuffs, balls and chains-Confederate jewelry, Some rest on cots, on boards, with blankets, some without them, And when they get to sleep the big bugs often rout them;

They never sleep in quiet though erer so much drowsy,

For the vermin are so thick and big, the lice themselves are lousy. We have eighteen kinds of food, though 'twill stagger your belief. We have bread, beef, and soup, and bread, soup, and beef;

Then we separate about, with twenty in a group, And get beef, soup, and bread, and beef, bread, and soup; For our dessert we obtain, though it costs us nary red, Soup, bread, and beef, and soup, beef, and bread. 
The bread we usually get is of a very good sort, True, it is the staff of life, but our staff is rather short. Our beef's so lean and drs, that, swallowing, it will bound back, Unless we recollect afore, to try to grease the track. It is too tough and strong, for our noses or our knives, The cattle were so poor and thin, were killed to save their lives. The hides are made up into shoes, the sinews into strings, The marrow into soup, and the bones in pretty rings. Our soup is much too weak, to please a very high liver, 'Tis made of beans, bugs, and rice, and extract of James River.

Now I're told you what we eat, whether we're well or sick, What we drink is never strong though sometimes rather thick. Our drink is rarely river water, except to save from death, And then for want of whiskey we smell an officer's breath. Meat and drink are now so scarce as to raise a serious doubt, Whether the Confederacy is not about played out. Number one and two you've heard, and now in division third, I will say a word about the way we are officered.

\section{PART III.}

Military officers of the very meanest stuff, For every local post, are considered good enough. In officering Richmond they varied not the general rule, To appoint a drunkard, a tyrant, a coward, or a fool. It is plainly to be seen that in a little while When Satan scoops his jervels up, in Richmond he'll get a pile. At the head of Richmond post they've placed a Marylander, And like the devil in regions lost there sits General Winder. He snaps and snarls, he rips and swears, whether sober or tight, The old villain's heart's as black as his head is white. All through this vicinity they bate him as hard as they can, Nor ever slander him with the epithet of decent man. However mean, he's a patriot, that mas be understood, For when he left the Yankee land, 'twas for his country's good,

We come to Major Griswold, who is our Provost Marshal, He's a little prejudiced, which makes him rather partial ; 
But when compared to Winder he seems no virtue to lack, As green is almost white by the side of jet black.

And there's Judge Baxter, who also is a qucer old case, He has so large a centre he can hardly change his base. IIe says whiskey's a dangerous thing to have about the town, So, with all his might, he's for putting whiskey down. Whiskey is fifty cents a drink, and of the meanest sort. The Judge, to get his money's worth, swallows it by the quart. I will slyly tell you, boys, if your money you begrudge, How to get your whiskey cheap-step up and tap the Judge.

In the door of the Castle, like a stopple in a jug, To shut the prison's mouth, they've stuck a Baltimore plug; It is Captain Alexander, who is so cross and spunky, He is certainly not fit to command an oyster pungy. The Captain is such a case as may be often seen, Who thinks he's very smart, but is invisible green; He is a thundering blower, but would not dare to fight, As dogs that bark the loudest are seldom known to bite. Yet he has streaks of good, as well as mean, mixed for relief, The first are scarce and thin like fat in Confederate beef. IIe also came from Maryland, and mean as Nick can make him, And the reason why we keep him is because the devil won't take him.

Allen is a smooth old rat, that is truthfully said, He shines with black from boots to hat, his face shines with red; He pours down whiskey double-quick, there is no doubt of that; Sometimes he makes believe he's sick, but it's a brick in his hat. Old Allen is a villain of the very darkest stripe, He'll go home to purgatory as soon as he is ripe. And if he does not blow off steam and soon shut down the brakes,

In a dream of delirium he'll find his boots are full of snakes. He has an oily tongue and face full of deceit and evil, And should Old Nick miss that scape-grace, there's no need of a devil

A Private. 


\section{News of Libir.}

Monday, September 28th, 12 x.

Rumored that the exchange commissioners did not meet yesterday, as was expected.

Four P. Mr.-Rumor says that the United States commissioners, having heard of Spencer Kellogg's execution, immediately returned without awaiting the arrival of the Confederate States troop, and that there will be no exchange of prisoners soon.

September 29th.-As a result of yesterday's news the spirits are drooping in all, except those of the huxtering fre, who seem to have renewed their diligence.

September 30th.-We have news from a reliable source, that all the Federal officers are to be paroled and sent North on the next truce boat.

Three P. M.-Since receiving the above telegram we have received information that no exchange or parole is to occur, as the exchange agents have not acceded to any propositions yet offered, and that the next truce boat will bring blankets and clothing for the Libby family.

October 1st.-The huxtering fry say they will allow fruit to be conveyed down Red Lane pike, if the teamsters will allow them a profitable remuneration.

Latest from the hospital, four and one half P. M.A United States gun-boat brought dispatehes that no exchange eren of privates would be allowed until the sase of Kellogg is satisfactorily explained.

Still later, nine P. M.-The commissioners are to meet on the third of October. The United States 
commissioner will bring six gun-boats along to pro. tect the white flag.

Yours,

JACK RUMYRTRAP.

"South Wixdow."

No. 2.

Shall I tell you why, Mr. Editor, that ensconced in this out-of-the-way corner, close to this cross-barred frame, why I call it my South Window? Because memory reverts to another scene and time in by-gone days, when a fair bright face oft watched adown the road, the first to welcome the toiler home. I wonder if she sits in that "south window" now and waits the wanderer's return?

Ah, Mr. Editor, whose heart so cold it would not warm with thoughts like these? Ever as memory goes back to those fast-growing far distant hours I picture my happy home. Situated a few miles away from the busy hum of the metropolis, on a little bay, nestled among a magnificent grove of chestnuts, hid by them from the sight of the passer-by, is my home.

There at night, after the work of the day, have I retired in keen enjoyment of the comforts of a happy home, surrounded only by those who lore. Such a life is almost the poet's dream of Elysium. There in the early mists of the morning have I mounted my horse for a ride along the sea-shore, or through the clover-fields; or in the moonlit summer's evening have unfurled the sails of my "Bonny" yacht and glided on the smooth surface of the bay, hour after hour, happy in forgetfulness of all save the present. This, in all its wide meaning, is home. 
And here, Mr. Editor, the oft-repeated prayer arises, may the day soon come, when you and I, and all of us, shall leave our prison abode, and be per. mitted to clasp our loved ones in a warm embrace, when the dismal clouds of war are scattered, and the sunshine of peace shall fall upon a reunited land.

Once more, Au revoir.

Captann P.

\section{The Libbrad.}

(Written expressly for the "Libby Chronicle.")

"Of Libby's lice to us the direful spring Of woes unnumbered, heavenly muses sing."

\section{Homer modernized.}

Think not my theme so trifling, none you can mention Receives in Libby half so much attention. A phonographic class of half a dozen score, In one short week, falls off a half or more; French, too, and Spanish, as all can plainly see, Lose their students in the same degree; But who so lazy, so busy, or so nice, Neglects to give an hour each day to lice, Will be beset with troubles great and small, And have hard scratching to get along at all. If poets write of battles 'twixt frogs and mice, Why not of skirmishes 'twixt men and lice? And while these verses rude we are inditing, Look 'round to see the different styles of fighting.

Watch Pugilisticus, he in a trice Pulls of his dirty shirt to fight his lice; His muscles thus of cumbrous duds bereft, See with what science he "puts in his left" Upon the bodies of his luckless brood, And Pugilisticus has gained "first blood." With double fury he "puts in his right," $\Lambda$ nd Pugilisticus has "won the fight." 
And thcre's Historicus, with scabby back,

Would trace their history as he hears them crack;

Wonders if these lice bear the same description,

As those once scratched by $\mathrm{Pharaoh}$ and the Egyptian.

He tries, in rain, from facts and from analogy,

To thread their lineage and genealogy.

He learns, however, with very little pains,

The proudest blood of Libby is flowing in their veins.

Ife marks, too, that the death of these, his little foes,

Is not as ignominious as thoughtless men suppose.

Sisera, a great warrior, was slain by Jael,

With those unwarlike weapons, a hammer and a nail,

While to slay these, so very much abused,

Although there be no hammer, two nails are al ways ased.

Mark now Gallantricus, that nice young man,

With taper fingers made to wield a lady's fan,

Much disgusted, see him hunting, half ashamed of being seen,

Thinks it "rery unpretty," lice should stay in shirt so clean.

See now his handsome risage, what contortions and grimaces!

As if to scare the nasty things by making ugly faces.

What would she think, his would-be, future sponse,

To see him strip and squat and grin and louse?

Behold Theologicus, with rererend face,

Peering with care in every hiding place.

And while his little flock crawls 'round through heaps of slain,

Such thoughts as these come crawling through his brain:

What if 'midst all the creeds and doctrines which so stagger us,

That should be true announced by old Pythagoras!

That after death men's souls, instead of going

To hearen or hell according to the showing

Of orthodoxy teachers, simply go forth

To inhabit birds and beasts, insects and so forth,

Base or noble as their lives may show forth.

Most in this prison, if I judge aright,

Will live in noble beasts and birds of lofty flight.

But some there are who'll live again as hogs,

Some skunks, some asses, some as snappish dogs. 
A very few have souls so small and base That even such as these they would disgrace. Crammed in this loathsome prison, scorned like slaves, Insulted, starred by coward traitor knaves, The men who in our suffering have betrayed us, And fawn on those who brutally degrade us, Even such small souls will find a fitting nice, And live hereafter in loathsome Libby's lice.

There's Philosophicus, with thoughtful brow, Who knows the "why" of crerything, the "what" and "how." He watches his louse to learn each secret habit, Before with bloody fangs he proceeds to grab it. Sees it in its cozy nest recline, Marks it making love and observes it dine. With wise discrimination he can trace The difference 'twixt the louse and bedbug raceBut I'll cease scratching lines and scratch "Scotch-fiddle" tunes, At something crawling in my pantaloons.

Lieutenant Colonel W.

Who is Responstble for Non-exchange of Prisoners? BY LIEUTENANT COLONEL N.

It is with much regret that we announce the fact to the readers of the Chronicle, that there are those among the officers now confined in this delectable (?) locality, ycleped Libby, who are uttering curses, "not loud, but deep," against our government, for permitting them to remain here so long. These officers evince more of the spirit of spoiled children, than of that manly courage and patience which should characterize the actions of the American officer and soldier.

The officer who utters complaints against our gov. ernment for his continued incarceration, shows that 
he does not understand the principles involved in the controversy in relation to the exchange of prisoners, or else he is prompted by motives altogether selfish and unpatriotic. The exchange of officers was suspended in consequence of the unfair proceeding of the Kebel authorities, about the first of June, in retaining certain officers in an unjust and arbitrary manner. Among those thus retained were Colonel Streight's officers, Captain McKee of the Fourteenth Kentucky Cavalry, and Lieutenant Conn of the Second Virginia Cavalry. Our commissioner, on discovering this injustice, respectfully informed the Rebel commissioner, that all exchange of officers would be suspended until the Rebels would exchange officer for officer and man for man, according to rank and to date of capture.

The Rebels, at that time, were anticipating a series of successes, which they have not realized, though they persist, with a dogged obstinacy, in the nnjust course which they had marked for themselves. Instead of removing obstacles which they had thrown in the way of the cartel, they continue to increase those obstacles by high-handed acts of injustice and cruelty, and make the affair more complicated. All that is necessary, is to return to the cartel and proceed as formerly. When the Rebels do this, our government is ready to exchange; but until then, it acts properly in refusing to exchange. A partial or special exchange would leave many an unfortunate prisoner exposed to even worse insults and indignities than now. The suspension of the cartel will doubtless continue unti] the Rebels are willing to conduct the exchange on fais 
principles, and every patriotic officer should submit to his fate with manly fortitude.

Our government has not forgotten us, but, on the contrary, it is pursuing that course which will result to our advantage. Should partial exchanges be made, a portion of the officers would be held as hostages, confined in wretched cells, and reserved for hanging or shooting, for the amusement and recreation of the chivalry. Such exchanges would add to the comfort of some, but would increase the sufferings of others. What officer is so devoid of humanity as to be willing to accept his personal liberty at such expense? If there be any such in Libby, they had better tender their "immediate and unconditional" resignation as soon as possible, and retire to their own place. But, in the language of Holy Writ, let us "endure hardness as good soldiers," trusting in the God of battles to deliver us; assured also that we are not forgotten by father Abraham, who is evidently doing all that justice and mercy can prompt him to do for our relief. While it is well for us to invite the aid of our influential friends in the North, in this matter of exchange, it is equally proper to bide our time with patience and resignation.

\section{An Officer and a Gentrlenian.}

\section{BY LIECTENANT COLONEL S.}

It still runs in the memory of many when, to be an oflicer of the American army, was to be, as a con sequence, a gentleman and a man of honor. The claimant to official rank, of whatever grade, was ever the recipient of marked attention. The announce- 
ment of his arrival was paraded in the journals of the day, and the blandest smiles of mine host, and the cosiest chamber of "mine inn," were instantly at his command. From the great, the learned, the wealthy and the fair, hospitalities, invitations and favors of every kind were tendered him, and his sojourn in town or country was a continuation of fête days, culminating in intensity as his leave of absence drew near its close.

"All men revered him, all women loved."

To impugn his character, or to doubt his honor, subjected the utterer to the closest investigation, or to the stern arbitrament of arms; while, to him, to fall from his high position, was a descent second only to that of Lucifer. In camp, courteous to his subordinates, he was ever respectful to his superiors; and in the field he faced the foe, because the path to glory is through the field of danger.

For his associates, with whom he had encountered many vicissitudes "through field and flood," he entertained an affection dearer than the ties of relationship; and was ever ready to aid, support and defend them at all hazards. Such were the life, character and attributes of an American officer at the commencement of this contesi ; and whether enrolled in defence of constitutional right and a just government, or engaged in marshalling the ranks of the disloyal and the traitor, to this day he retains, in an eminent degree, most, if not all, of these virtues.

Let us now turn to the volunteer. Called to arms by his country's need, the gifted, the honored, the brave, throwing off the lethargy of peace, donned the 
uniform of his government, and, pledging his life and his sacred honor, rushed to the defence of a timehonored flag and the beloved institutions of his forefathers. A hearty volunteer in a glorious cause, he brought with him the enthusiasm of the patriot and the loyalty of the citizen; accustomed to comfort and nurtured in luxury, he endured the privations of the camp and the bitter experiences of martial life with cheerfulness and obedience; proud of his cause, his country and his uniform, he strove so to guide his steps that each and all might be honored by his advocacy. Acquainted with the amenities of civil life, filled with the recollections of the social distinctions accorded to the oflicer of former days, and a firm believer in the attributes of the chivalric soldier, he naturally turned to his immediate associates in arms, for an exhibition of those characteristics which have garnished the pages of history and peopled the world with heroes.

The child which nightly awakens the denizens of Libby by its eager search after the paternal Teet; * to whom the knowledge of light, air, and impalpable being is but a thing of yesterday, is yet old enough to chronicle the downfall of these expectations; and could he answer, young as he is, his youthful visage would rival, in intensity of color, his spanked extremity, after a severe flagellation by his irate ancestor, while recounting the reverse of the picture. For, did he speak truly, he would tell of the lie bandied,

* Captain John Teed could imitate the crying of a little child so perfectly, as to render detection almost impossible. Hours of intense merriment were occasioned by this thing alone. 
in lieu of the sacred word of honor ever implied; of the act and gesture of filth and indecency, in place of the merry joke and good-humored repartee; of the blasphemous response to the authorized command of the superior, instead of the graceful obedience of the subordinate: but, worse than all, he would tell of the rights invaded, the property purloined, and the pocket rifled of one officer by his fellow.

Mr. Editor, had such a statement been made in any journal as respectable as your own, previous to my advent to Libby, I would have deemed it my duty to hunt the anonymous slanderer from his secret lair, and nail the calumny to his forehead; but now, alas, a short but painful experience in a military prison has revealed to me, that an officer and a gentleman are no longer synonyms; that the uniform of the soldier may cover the carcass of the sneak, and the shoulder-straps of the officer may serve to conceal the brand of the thief. Dare any one deny this? If any such there be, let them dispassionately investigate the record of the past two weeks, and, ere venting their virtuous indignation, inquire of the first officer they meet of his experience; or, better, let them consult the official announcement, affixed to these walls, proclaiming the loss, by theft, of one hundred and eighty dollars within the past fortnight; or they may be enlightened by the recital of innumerable petty larcenies, minor scoundrelisms, and sneaking pilferings unworthy the talents of the meanest thief that ever graduated from the Five Points. Even the honor which obtains among rogues is forgotten, for we have it on record that thief has robbed thief, and the 
sneak preyed upon his brother. And yet, forsooth, these miscreants bear a commission, hold a command, and, by my manhood, even sport a sword. Of such men the immortal Shakespeare has written thus:

"He will steal, sir, an egg out of a cloister. He professes not keeping of oaths; in breaking them he is stronger than Hercules. He will lie, sir, with such volubility, that you would think truth were a fool. Drunkenness is his best virtue, for he will be swinedrunk, and in his sleep he does little harm, save to his bedclothes about him; but they know his conditions and lay him in straw. I have but little more to say, sir, of his honesty; he has everything that an honest man should not have, what an honest man should have, he has nothing."

I would not have it understood, Mr. Editor, that a majority, or even a tenth of our number, are open to these charges. The bad among us are, I am proud to say, numerically small, but that they are skillful and proficient their present concealment evidences. Brought from the various armies of the north and west, we are, in a degree, total strangers to a large number of the present inmates of this prison. The very man who shares our plank is unknown to us by name or state, and may be, for all we know, the mirror of knighthood, or the veriest poltroon.

A sufferer by the peculations complained of, we turn in querulous haste, with jealous eye, upon the first comer, and are more likely to suspect the innocent than to detect the guilty; and we ourselves, while seeking our despoiler, are in turn suspected by a fellow-sufferer, who deems the eager looks of the 
loser the preying scrutiny of the thief. For our own sakes, then, let us combine to purge our body of this moral blot, to rid our profession of this novel stain. To one or the other, the condition and opinion of each and every man are known. The knave and the coward, under a close surveillance, must inevitably be discovered, while the brave and the honorable can rarely be misunderstood. Mark then every man by his words and actions. Scan closely the unguarded morements and desultory remarks of the suspected. Neet cunning with stratagem, and ply the rogue to his ruin. The cause we advocate and the uniform we wear demand that we should expose the unworthy and unmask the dishonest; and it is the duty of every honest man to bring the recreant thief to that justice he so much needs and fears.

[Written expressly for the Chronicle.]

The Irruption.*

br LietTENANT $\mathbf{N}$.

'Twas night, and Rebel Libby, wrapped in sleep,

Was hushed to quiet, weird, sublime and deep:

Along the floor the moon's pale, flickering beam,

Athwart each risage, shot with fitful gleam,

As if in pity she did stoop to bless

And cheer each prisoner with a fond caress.

And what a sight that moon-lit floor displays!

In each pale face, upturned to meet her rays,

She shines resplendent, and paints in colors bright

A cheerful soul within, content and light;

Yet through its workings, now in fit and start,

Unfolds the sorrows of an anguished heart.

* This poem was written soon after the arrival of our officers captured at Chickamanga. 
From scene like this we turn our weary head, To court unwilling Sleep to bless our bed; When, hark! upon the stillness harshly breaks A sound, that to the base old Libby shakes; Like to the war of billows, tempest-clad, That beat old Ocean's shore, in foment mad,

Or cannon's thunders loud, when heard afar, In battle's dreadful strife, "grim visaged war." It nearer, louder comes. "What can it be?" Each wakened dreamer cries, and starts to see. And what a sight meets their astonished gaze, By light of moon and candle's flickering blaze!

The vandal Yankees, in "irruption" bold, In numbers seventy and one all told, Are in a horde dark Libby's cells invading, And 'long its files with stealthy tread are raiding; Their guide a contraband: deceitful black, To thus direct the cunning Yankees' track.

Surprised, awaked by the in-coming foe, The inmates rise to strike a mortal blow; Aloft they rise in majesty so grand These dreamers, this incarcerated band; With mingled cries of joy, of fear and rage, They quickly haste the coming fight to wage;

When lo! above the din cries out a wag: "'Tis not the randals, only Braxton Bragg, Who comes to reënforce the garrison With gobbled troops of Teuton Rosy's men." 


\section{The Beautiful.}

Benuty is not confined to nature, to trees, to flowers, and to the material world. It is the prime element of spiritual life. It mauifests itself in its highest and most sublime form, in the nobler traits of human character and conduct. The only really substantial beauty in the world is truth, mercy and love. The natural rose soon fades, but the roses of moral conduct and spiritual life bloom forever.

The highest type of beauty this world ever saw, is contained in the life and death of Jesus Christ. There is beauty in the heavens, the stars, the clouds and the arch of blue; in the wide waste of old ocean, in the bills, plains, mountains and valleys of the earth. But there is nothing in these to compare with the feeblest effort for the elevation and welfare of the down-trodden and oppressed, the poor and despised, the ignorant and unfortunate, the erring and lost of the human race. What beauty in a fault forgiven, in a tear dried, in an error corrected, in a want supplied !

There is sublime beanty in Niagara, but a sublim. er in the widow's gift of mites, or in the heavenly mission of Florence Nightingale; more beauty in the refusal of Moses, than in the pomp and splendor of Pharaoh; more in the ragged and despised Lazarus, than in the purple and fine linen of Dires; more in visiting widows and orphans, than in the glory of rain princes. Such are the beauties of the soul, which reflect the brightness of hearen. These beam with the rays of eternity.

S. G. H. 


\section{Lights and Sirades in Liebr. No. 2.}

How true is the saying that a man cannot long hide his real character. Remore him to the antipodes, or utterly change the circumstances of his life, and he is still the same. Bayard Taylor once thought that if he could ever tread the sacred soil of Palestine, he would be a holier, better man, but he writes that when he stood in the consecrated ground of Gethsemane, he was the same Taylor still. The soldier will be a soldier, place him where you will. Who can doubt this, who looks out upon the teeming multitudes of Libby, some bright morning, after the light of day has aroused the miserable sleepers? For then, even without orders, and thus making himself liable to a court-martial, every man sets himself to "skirmishing." The better to accomplish his work, like the racers in the Olympic games, he casts aside all his loose garments, which frequently includes his entire wardrobe, and great preparations are made for the conflict. The soldier must be a soldier.

Wo! wo now to the enemy that may chance to linger in the open fields, for the sharp-shooter will certainly dismount him. A dash is made, the ground is cleared, all flank movements are prevented, and now there is a falling back to the fences and ravines, which, in prison parlance, are called "seams of shirts and pants." The battle now deepens. The reports of the missiles of death are numerous. Human blood is spilt. The casualties are many, for the black flag is raised; no quarters, no prisoners, death or victory. 
This battling for human rights against brute force is going on in every room of the prison throughout the day, unless it be on those fortunate days, when the call is made, spreading like wild contagion from room to room: "The mail! the mail." Whatever men are doing is laid aside, and a rush is made generally to the upper west room, where one of our officers reads aloud the addresses. Every one hopes for a letter from the dear ones, a brief, yet precious memento. Eagerly each one listens for the calling of his name, though but a few are ever gratified with a message. The bustle of distribution orer, each man regains his accustomed place, when an unusual quiet reigns. The disappointed are communing with their own thoughts, while others are busy with words from their loved and distant. As we pass from place to place, how easily we learn, without inquiring, what news has been receired. Here a countenance glows with a delightful delirium over words of love and pleasant intelligence, but, there, hidden away as far as possible from the crowds, is one whose flowing tears fall upon the page that tells of ominous sickness or sorrowful death. Fain would he retire, as Joseph did from his brethren, to weep alone, unseen by any, sare by Him, who gives and takes away, who, though He aftlict on the one hand, always comforts on the other.

Thus mid hopes and fears, sorrows and joys, mid scenes of strife and toil, the day wears away. We hare "skirmished," cut bones, studied books, recited lessons, heard numberless and contradictory rumors about exchange, witnessed new arrivals of "fresh fish," swept our rooms, cooked and eaten our scanty 
allowances, formed new and long-lasting acquaintances, and the twilight, at length, with its mellow haze, settles down around us, to hide the weary day. This is the most sacred hour in the history of man. Manual and purely intellectual labors are laid aside to give place to higher, nobler toil. Now the weightier thoughts, which lay deepest during the day, rise to the surface, and become ruling forces. The ruder passions hide themselves, or, at least, keep silence, while the finer sentiments claim control. It is now that the better angels of our natures fold us in their wings. Memory, with her busy hands, gathers the richest fruits of by-gone days, and imagination paints the loveliest pictures of the friends we cherish. Who can portray the prisoner's depth of feeling in this hour, his deep study, his sad ennui, his brilliant poesy?

His heart surcharged with the rushing currents of emotion, seeks some object of contact upon which to cast its burden, and the mind, conscious of weakness, desires to rest upon a foundation broader, surer than itself, and he cries, "Lead me to the Rock, that is higher than I." It is the natural hour of prayer, and Libby becomes a sanctuary of worship. Most of the prisoners gladly welcome the call to "evening prayers," and what a moral in the scene! Men who had never met before, of every shade of creeds, seem moved by one common impulse, and absorbed by one great desire to worship God. The number of those who take no interest or part in the solemn service is nightly growing less.

They gather in a circle and a familiar hymn is 
sung by all with unusual zest. How appropriate for us to make these old, dingy walls echo with sacred song! Would they might repeat the strain to their cruel owners! We kneel in prayer, while one, appointed by his brethren, leads the devotions. Well it is for us all that we can join in an exercise which has so often calmed the troubled heart, sent joy among the disconsolate, inspired the reformer in his noble work, nerved the warrior in his dangerous path, and crowned the dying Christian with victory. Memories of home come crowding thickly upon the heart, as loved ones are commended to the care of God. Humility is felt as sins and shortcomings are confessed. Hope spreads her wings, and moral vigor is imparted to faith, as precions promises are pleaded. Patriotism kindles brilliant fires upon her altars as dear country becomes the burden of petition. Hearts glow with intense enthusiasm as the fervent prayer to "Our Father" arises for our release from this confinement, which is becoming so oppressive.

The well-known doxology is sung, or the oft-repeated prayer of childhood, "And now we lay us down to sleep," etc., rendered to the tune of Hebron, and the worshipers disperse with "strength renewed" and "joys divinely sweetened." Darkness now enshrouds the landscape around Libby, and like caged birds we sit by the barred windows gazing on the stars that shine in the distance. Under similar circumstances, undoubtedly, the poet traced upon the walls of a house used for a hospital, during and after the battle of Chantilly, the following touching lines: 
I am far from my home to night, No cherished friend I see, Thongh all the stars in heaven are bright, They are not as bright to me As once they seemed in days gone by, Before I learned to roam, Bespangling all the valley o'er, $\Lambda$ bove my distant home.

But my Flag and Country bade me go, And I will not repine,

In all my wanderings to and fro,

Whatever lot be mine, For still, perchance, the day may come,

When I no more shall roam,

When those who sigh that now I'm gone,

Will bid ne welcome home.

\section{Aderetisemert: \\ Barber and Hair Dresser.}

Adjutant Lombard respectfully informs the inhabitants of Libby, that he has opened a new Tonsorial Shop on Main street, four doors north of Sanderson's eating saloon. Thankful for past farors, he solicits the patronage of the public.

Attorney and Counsellor-at-Law.

Major Rogers would announce to the public, that he has retired from military life, and resumed the more important business of the bar. He may be • found on Egan street, one door south of Ryan, Litchfield and Co.'s Soap manufactory. All business promptly attended to. 
Important Appointment.- We are happy to learn that Hon. John Haldeman has been appointed Prosecuting Attorney for the Commonwealth of Libby.

Recovering.-Te are informed that Hon. Judge Willets is rapidly recovering from his dangerous illness, supposed to have been occasioned by bathing at a late hour at night. He will be able to resume his duties in a few days.

A Card.-Dr. Uhler, Physician and Surgeon, after a long and successful practice in the armies of the United States, has returned to Libby, and located opposite Mitchell's gymnasium. Will attend all calls in his profession.

[Reported for The Libby Chronicle.]

The Mock Trial.

Thursdar, August 20, 1863, will long be remembered by the denizens of Libby, for the fun and general mirth occasioned by the trial, at a mock court, of one of their number. About eleren o'clock the exciting affair was announced by the stentorian roice of the quasi sheriff, "Hear ye! hear ye !! hear ye !!! the honorable court for the county of Libby, and state of Imprisonment, is now open. All ye who hare business therein, draw near and ye shall be heard."

A motley crowd at once assembled at the call, and beheld a solemn-faced, grey-headed cavalry captain, who was to play the rôle of judge, seated upon a lofty arm-chair, made of a partly broken barrel. His mock dignity, professional air and shrewd hum r, frequent. 
ly convulsed the court and lookers on with laughter, during the proceedings. To the right and left of him were seated on impromptu benches of broken boards, sticks of wood, or on the floor, the district attorney, sheriff, under sherifi, counsels, sergeant-at-arms, clerks, etc.

The impaneling of the jury was rendered amusingly difficult to correspond with the other movements. Foreigners with the longest and worst-sounding names, had been selected for the bench, from the French, Germans and Hungarians, some of whom could scarcely understand a word of English. The foreman, when called up to be sworn, feigned he did not understand the questions of the judge, and responded in French. Every word filled the audience with merriment, and seemed to puzzle the court. $\Lambda \mathrm{t}$ last this barbarian was ruled out, as he did not know the language of the court. Meanwhile a bystander interrupted proceedings by vociferating that the fault was not the juryman's but the court's, as they ought to be competent to understand him. The judge thereupon ordered the arrest of the offender for conteinpt of court, and the sergeant-at-arms cleverly executed the order. The next juryman questioned was as deaf as an adder, and the third was a Dutchman, who carried out the figure most charmingly, and for some time kept the room in an uproar of laughter and applause. At length a jury was duly impaneled, and a grave-looking prisoner was brought to the bar, charged with having disturbed the peace of the place, by seeking to enjoy the raptures of a clandestine bath, contrary to the laws of the people. 
As the witnesses were brought upon the stand, they were required to raise their left foot or both feet, and to subscribe to the following oath: "You do pompously swear that jou will tear, tatter, transmogrify and torture the truth, the whole truth, and everything but the truth, so help you Jeff. Davis." If the witness was a Quaker, and did not wish to swear, he could affirm under the pains and penalties of being put into the sink.

The accused soon became the butt of all the mischievous witticism of the occasion, but conducted himself in a manner becoming the best good nature. The trial was continued for several days with unabated interest, in which was displayed no little amount of juridical knowledge, and consummate skill and ingenuity in managing a case. The counsel for the defence was indefatigable, and succeeded in presenting the laughable arguments, with no little array of evidence, that the prisoner had not been known eren to wash his face, since he had taken his abode in this county, and that he was subject to fearful attacks of hydrophobia. Witnesses were also subpœnaed, who proved a case of alibi, by testifying that on the night in question the accused was seen coming out of an icesream saloon on Main street, Richmond, with a Confederate lady on his arm. In proof of this, the fragment of a letter, found near the wash tub, was produced, signed "Susan," the contents of which greatly defamed the marital fidelity of the aged warrior, and revealed some highly ludicrons incidents of his amatory experience.

The respondent listened to all these personal jokes 
with excellent good temper, and none seemed to enjoy more than himself the comical buffoonery of witnesses and lawyers. But notwithstanding the artful pleadings of his counsel, a rerdict of guilty was at last rendered, and he was sentenced by the court to imprisonment for forty-eight hours in the sink. This severe punishment was afterward commuted to a public promise of good behavior in future, he having entered into a recognizance to treat the judge, jury and counsels, whenever they should get out of Libby, which obligation will undoubtedly be faithfully kept.

Clerk.

\section{Liguts and Sirades in Libbr.}

No. 3.

As we sit at a safe distance from the window, to avoid the sentry's notice, and gaze on the bright stars, we can but reflect on the purity of the Architect of the universe, whose " all-seeing eye the sun, moon and stars obey, and under whose watchful care even the comets perform their stupendous revolutions," and yet who condescends to dwell in the heart of the lowly and contrite, even among the wretched creatures who inhabit this dingy prison. How true is the poet's rhyme, which we never so fully understood before:

While blest with a sense of his love,

A palace a toy would appear;

And prisons would palaces prove,

If Jesus would dwell with me there.

While thus we muse we are accosted by a fellowprisoner, who has recently been converted in ou: 
evening meetings, one of a large number who have thus passed "from death unto life," and found this dungeon a Bethel to their souls. What a privilege it is to witness in this place such a work of reformation! Like the old apostle we can say, "The things which happened unto me have fallen out rather unto the furtherance of the gospel; so that my bonds in Christ are manifest in all the palace, and in all other' places."

Taking this young disciple by the arm we will saunter through the different wards of the prison for exercise, conversation and observation. A few flickering candles here and there light our way. Objects of interest meet us on every hand. No place, perhaps, presents greater contrasts. Here are the noisy and the quiet, the studious and the careless, the sad and the happy, until you are led to exclaim, "How strangely are the lights and shades, the joys and sorrows, the good and bad, of this world, mingled in one mysterious mass!" Already at this early hour of the night lies a man upon the dirty floor for a bed, with, perhaps, a poor lousy blanket under him. At his side are those who sing londly, or whistle for their amusement. Yonder is a group busy in conversation. Here an individnal is striving to study by the pale light of the moon, or by the light, nearly as pale, from a distant candle.

At length we are attracted to a noisy group around a candle, whose singular occupation is a subject of no little query. Their attention seems to be wholly giren to a pack of little paper billets, strangely figured outside and inside. One would naturally suppose these 
things to answer for a baby's playthings, or a child's picture primer. Suddenly one of the party takes up the bunch, shakes or shuffles them rapidly, and then distributes or deals them out to his comrades. Let us watch and listen, and thus we may learn something new. We hear one speak of "hearts." We draw nearer, for we begin to think that they have hearts after all that has been said of men following their occupation. "Diamonds," shouts another. We draw still nearer, for if these men have true hearts and deal in diamonds, they are not as dangerous as they have been represented to be. We are becoming favorably impressed, when one says, "high, low," another, " jack and the game." What strange words! We are startled, and look upon the operation with astonishment. What are they talking about? "High, low!" do they mean high and low thoughts? Truly we see nothing very elevating yet. Is it high and low cards? We look in vain to see one card much higher than another. We cannot understand this jargon. Suspicion seizes upon us. We fear they are "jacks" at all games, making use of "low" as well as "high" principles to carry ont their designs. Soliloquizing upon the singular scene, one of the party cries out, "clubs!" Our suspicions were not groundless. These men who profess to have hearts, and to appreciate the beauty of diamonds, carry with them clubs, doubtless to assassinate either strangers or one another. Trembling with fear we start to leave, when the party cries out for "spades." We are correct, these men are professional murderers, for they have clubs to slay their victims and spades to dig their graves, and what 
else we are not advised, and as we fly in terror from the scene, we hear them speak of "trumps." Poor fools! we think they are vastly mistaken, if they believe that they can kill one another with clubs, dig one another's graves with their spades, and then, Gabriel-like, call one another to life again with their trumps. The men must be either crazy or very childish, and their conduct, it seems to us, can be justified only on the ground that, especially here, "a little nonsense now and then is relished by the best of men."

As we pass into another room we meet quite a procession, representing a country caravan on a small scale. The elephant is none other than two officers, bent forward, with a blanket thrown over them, while two sticks of wood protruding from the blanket, make the tusks. One man mounted upon another is the camel, and another on all-fours the bear. These are paraded through the rooms, headed by bearers of torches, and a band of music, performing Yankee Doodle and other airs on split quills, hair-combs, tin plates and cups. Accompanying the show are hideous imitations of all kinds of fowls and beasts, with a menagerie-like effect, which would do honor to Barnum's American Museum.

Having passed by this amusing scene, we hear a rustling, grating noise, with the tramping of many feet, and a rush is made toward us. We step aside to aroid the shock. It is a "raiding" party à la cavalerie. Twenty or more of the most desperate characters among us form the squad. They dash through, srmed with broom-sticks, and other like weapons, sweeping all before them, upsetting erery thing and 
every body that comes in their way. These raiders are the terror of the more sedate of our community, and their rude, not to say heathenish practice, resulting in the discomfort and hurt of many, is justly worthy of the severest reprimand.

In another room we are drawn to a crowd, who, at intervals, shout and laugh as though frantic with joy. We elbow our way through the press to get a sight of the fun, when, oh! shades of the feathery king of the barnyard! here are fowls without feathers, spurs or crests, engaged in a "cock-fight." Two individuals have submitted themselves to the process known as "bucking," and now within a ring, marked with chalk on the floor, hop around, crow and butt each other in a "rooster-like" style, which results in one or the other, and sometimes both tumbling over in a most laughable manner. Each "bird" has his ring of betters, which lend no little amount of excitement to the play.

But our evening ramble is quite sufficient, and now weary, "like a quarry slave at night scourged to his dungeon," we wend our way to our humble pallet, which we welcome, though far from being equally satisfactory to our former lodgings upon the hard, cold ground. We lie down, but not to sleep at once, for we have not yet recited our catechism. How like the days of childhood, though great is the contrast between the subjects presented. Still it is well here to be reminded of these domestic animals, catechism and its mate $d o g$-matism. They are species of very ancient descent. The one has cleared the centuries of the past of their rats and mice of reli. 
gious folly, and the other has kept at bay infidelity's beasts of prey. The keen eye of the one, and the hoarse, threatening voice of the other, have given evidence of their usefulness. Time honors their labors, and from them history borrows important lessons. It is well that the fire-side and Sunday-school are not the only legitimate fields of their operations. Catechism, at least, has found its way into Libby. We cannot sleep until we have recited, whether the task be pleasant or otherwise. Now the grayhaired sire lifts his venerable head, and with his ancient, solemn, sepulchral voice, propounds his important questions to his listening, numerous family, who, by the promptness of their replies, evince a thorough study of the lesson. No subject is allowed to escape. The whole course of Libby experience is thoroughly canvassed, and wo to the man who has made himself subject of remark. Whatever men have on the brain (if they have any brain), whether bread or bones, French or Spanish, exchange or escape, all must be reviewed. Whatever one has done publicly, privately or secretly, by some magic power of the catechist, is brought to judgment. Such questions as these are asked: "Who hid behind the big gun?" "Who has star on the brain?" "Who offered to enlist in the Rebel army to escape imprisonment?" "Who undertook to wash his clothes in the coffee-kettle?" etc. The names of the several offenders are thrown out in answer, much to the amusement of the crowd. Thus many sleepless moments are whiled away in the midst of jokes almost too serere to be mirthful, and of ficts almost too startling to be true. 
Gradually the pounding on the floor with fists and feet dies away, the roars of laughter cease, and "Sleep, tired nature's sweet restorer," comes to drive away our cares and to put our sorrows in oblivion. We now wander through dreamland, where kind friends are met, lored ones held in fond embrace; battles too are fought, and bloody victories won, until the morn shall break again. 


\section{CHAPTER XIX.}

[The succeeding pages are deroted principally to the testimony of indivia. nals who have been confined in other prisons.]

\section{AT MILLIN-" CAMP LAWTON."}

Conspictors upon the list of Rebel prisons stands the pen known South as Camp Lawton, near Millin, Georgia.

The following is the testimony of Sergeant W. Goodyear, Seventh Regiment, Connecticut Volunteers, who was remored to that place from Andersonville on the first of November, 1864.

It was pleasantly situated, about eighty miles north of Savannah, in a country where pine forests abound. Indeed, these were a prominent feature in the external surroundings of many of the southern prisons. Trees would be felled, a clearing made, and here located the rude structure that was to be the cheerless home of thousands for long, weary months. Could a voice be given to these silent groves, and they become witnesses of what they have seen and heard, what revelations would be made of things that can never be known now!

The medium of human language fails to conrey all the meaning involved in prison life in the South. It is true that a great part of the suffering in this present war, as in all wars, must forever remain with the secrets of unwritten history. A few, who 
were themselves actors in the tragic scenes, may rehearse the story of their individual experience, and thus furnish, as it were, a key to unlock the gates through which others may enter and take a look. This is the only way in which the people at large can become acquainted with this thrilling portion of the war; and authentic and reliable statements are therefore of deep interest and importance.

\section{THE INCLOSURE.}

"Forty-four" acres of ground were inclosed by the stockade at Millin. The large pine timber, which was cut down at the commencement of operations for building the prison, was left upon the ground; and when the first prisoners went into their confinement there, they found these to be greatly to their advantage; for they were able to construct for themselves comfortable huts of logs and branches lying about them. In this respect they were more fortunate than many, or most others. The last division that entered had no shelter at all, or at least of any account. A small stream of good water ran through the centre, which the men highly prized, particularly as it afforded the much needed privilege of bathing. At the time of my arrival there, the list of prisoners numbered nine thousand. The weather was very cold and stormy; and as the majority of the men were very poorly clad, many of them being without shoes, blankets, or coats, and also without shelter, the suffering was very great. No medicine was issued to the men within the stock- 
ade, and but very few were taken outside to the hospital; consequently the mortality was fearful.

AVERAGE NUMBER OF DEATHS PER DAY.

"The number of deaths averaged from twenty-five to thirty-five per day. The prevailing diseases were such as are common to almost all prisons - the scurvy, diarrhea, and rheumatism. It was no uncommon occurrence for the morning light to reveal the pallid faces of three or four prisoners who had lain down side by side, showing that death had claimed them all during the night. Such sights were heart-rending to the most unfeelingthe most stoical. The prisoner is condemned to these things, and there is no alternative but for him to gaze upon them, however sad and revolting they may be. He must steel himself against that which once would have sent sympathy through his whole being-a gushing tide. It conld not be that the fountain of pity be stirred to its depths so often. Nature could not sustain the pressure; therefore it seems that the whole is something like a martyr process, in which the very juices of life are crushed out by an uncontrollable force.

"At the beginning of my stay at Millin, the rations which were issued were double the amount we had at Andersonville. We drew one pint of meal, six ounces of uncooked beef, six spoonfuls of rice, one teaspoonful of salt, as our allowance for twenty-four hours. Beans were sometimes substituted for rice; but these were so much eaten by insects that they were often thrown away withont being tasted. After 
a little while, however, the quantity decreased every day, so that it became nearly as small and poor as those issued in other prisons.

\section{INDUCEMENTS TO ENTER THE REBEL SERVICE.}

"The prospect of being exchanged or paroled was so small that some availed themselves of the opportunity to take the oath of allegiance to the Confederate government, and entered the Rebel service. The inducements which were offered them to do this, were three bushels of sweet potatoes, a suit of clothes, and one hundred dollars in Confederate scrip. I was myself acquainted with quite a number who did this; and although I would make no excuse for thern, I know the motive by which they were actuated. They knew no chance of getting out of prison alive. They had barely clothes to cover their nakedness, and they thought to prolong their existence in this way; and coupled with this was the idea of escaping and fleeing to the Union lines at the very first opportunity. But the whole thing was considered a mean, disgraceful act by every true patriot. I would have died a dozen deaths rather than to have been guilty of such a thing, and there were thousands of others of the same kind.

\section{VOTING AT MILLIN PRISON.}

"As the time of the Presidential election drew near, the Rebels expressed a desire that we should rote upon the question ourselves. Accordingly ballot-boxes were procured, and on the day when the people of the North were deciding the momentous 
issue, we gathered together in Millin Prison, and in the midst of great excitement, gave expression to our political preferences. We knew that it was war or peace. As we deposited our votes, so did we speak for one or the other, and show forth our position in the country's cause. At sunset the votes were counted, and the result was three thousand and fourteen votes for Lincoln, and ten hundred and fifty for McClellan."

\section{CAME TOO NEAR THE DEAD LINE.}

I am indebted to O. R. Dahl, late lieutenant, Fifteenth Wisconsin Infantry, for the following particulars relative to the murder of Lieutenant Turbayne, which occurred after my escape from Columbia :

"About ten o'clock on the morning of the first of December, 1864, Camp Sorghum was startled with the report of a musket, and soon the news spread through camp that Lieutenant Turbayne, Sixtyeighth New York Infantry, had been shot-murdered by one of the guard, a Mr. Williams of Newbury Court House, South Carolina.

"Turbayne was walking along a path that ran by the corner of a hut, near the 'dead line,' but inside of it. Along this path the prisoners had walked hundreds of times without fear, for it was on our own ground. As Turbayne came along, the guard brought his piece to the shoulder, halted, and ordered him back. He turned to go, walked a step or two, when the villain shot him through the back, the ball 


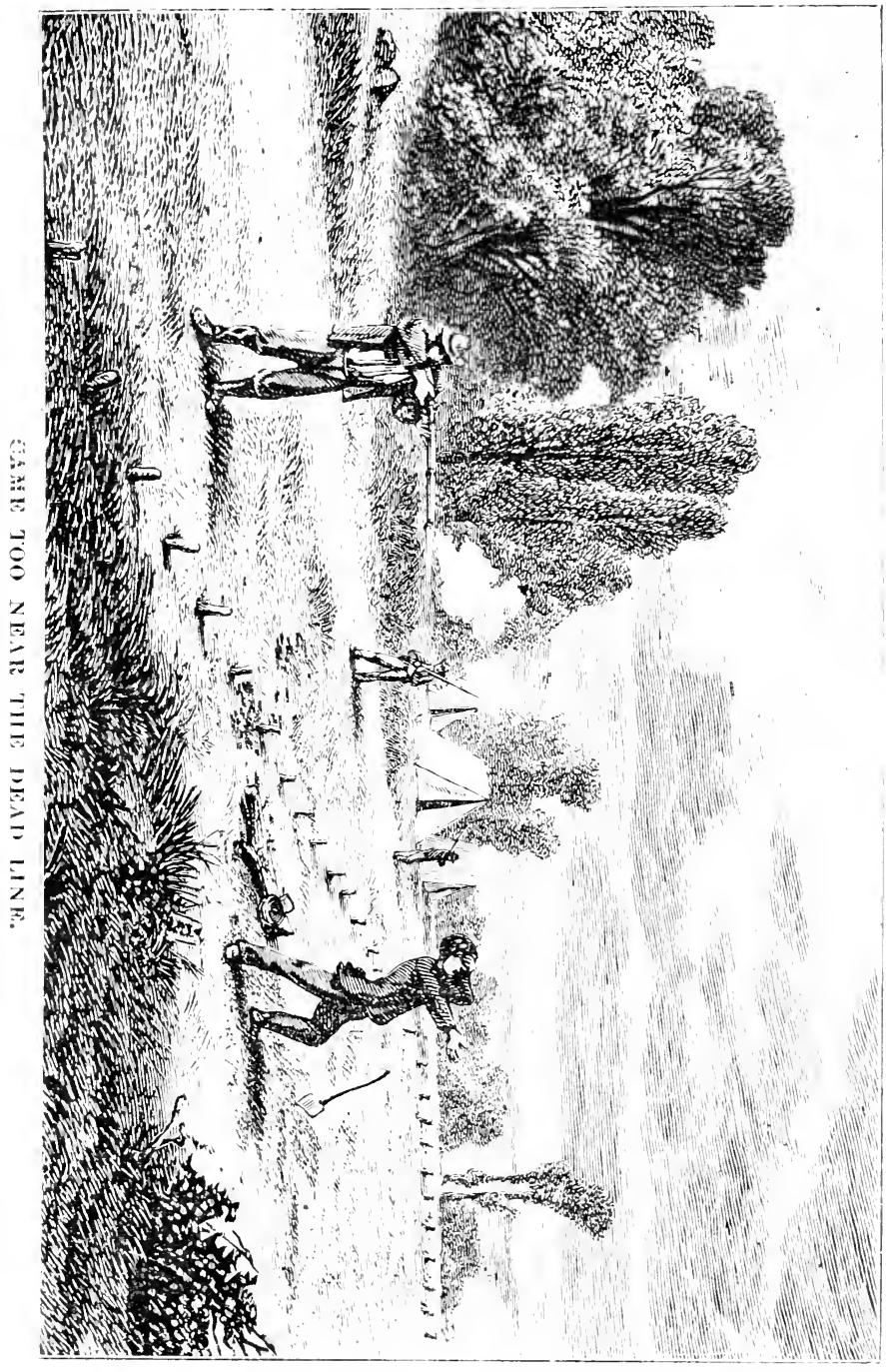



passing through his lungs. He staggered a few steps, fell, and died within a few minutes.

"Not only did Major Griswold refuse to investigate the matter, but after the murderer had been relieved by the officer of the day, he sent him back on duty that afternoon on the front line, and also into camp the next morning, surrounded by a body giard, for fear the officers would do violence to him-an in. sult of the blackest dye." 


\section{CHAPTER XX.}

\section{SALISBURT PRISON.}

THE prison at Salisbury, North Carolina, which became so notorious during the war as one of the most loathsome dungeons in Rebeldom, was at first intended as a place of punishment for southern soldiers guilty of military offences, and as a place of committal for hostages, who where usually sentenced to hard labor. It more recently came into general use, and hundreds of unfortunate victims said their last farewell in that miserable den. In order that we may obtain a better view of this horrible abode, I will transcribe the testimony of Messrs. Richardson and Brown, both widely known as correspondents for the public press.

The following statement was made by the former, before the Committee on the Conduct of the War:

"I was captured on a hay-bale in the Mississippi River, opposite Vicksburg, on the third of May, 1863, at midnight. After a varied experience in six different prisons, I was sent to Salisbury on the third of February, 1864, from which place I escaped on the eighteenth of December following.

"For months, Salisbury was the most endurable prison I had seen; there were six hundred inmates. 
They were exercised in the open air, comparatively well fed, and kindly treated. Early in October ten thousand regular prisoners of war arrived. It immediately changed into a scene of cruelty and horror; it was densely crowded, rations were cut down and issued very irregularly; friends ontside could not even send in a plate of food.

\section{RATIONS.}

"The prisoners suffered considerably, and often intensely, for the want of bread and shelter; those who had to live or die on prison rations, always suffered from hunger; very frequently one or more divisions of one thousand men would receive no rations for twenty-four hours; sometimes they were without food for forty-eight hours. A few, who had money, would pay from five to twenty dollars in Rebel currency for a little loaf of bread. Many, though the weather was inclement and snow frequent, sold the coats from their backs and shoes from their feet. I was assured, on authority entirely trustworthy, that a great commissary warehouse near the prison was filled with provisions. The commissary found it difficult to find storage for his corn and meal; and when a subordinate asked the post commandant, Major John H. Gee, 'Shall I give the prisoners full rations?' he replied, with an oath, 'No! give them quarter rations.'

"I know from personal observation, that corn and pork are very abundant in the region about Salisbury. "For weeks the prisoners had no shelter what. ever; they were all thinly clad, thousands were baro 
footed, not one in twenty had an overcoat or blauket, many hundreds were without shirts, and hundreds were without blouses. One Sibley tent and one A tent were furnished to each squad of one hundred; with the closest crowding, these sheltered about hali the prisoners. The rest burrowed in the ground, crept under the buildings, or shivered through the night in the open air upon the frozen ground.

"If the Rebels at the time of our capture had not stolen our shelter-tents, blankets, clothing, aud money, they would have suffered very little from cold. If the prison authorities had permitted them, either on parole or under guard, to cut logs within two miles of the prison, the men would have built comfortable and ample barracks in one reek; but the commandant would not consent,- -he did not eren furnish one half of the fuel needed.

HORRIBLE CONDITION OF THE HOSPITALS.

"The hospitals were in a horrible condition. More than half who entered them died in a few days. The deceased, always without cottins, were loaded into the dead-carts, piled on each other like logs of wood, and so driven out to be thrown in a trench and covered with earth.

"The Rebel surgeons were generally humane and attentive, and endeavored to improve the shocking condition of the hospitals; but the Salisbury and Richmond authorities disregarded their protests.

"On the twenty-fitth of November, many of the prisoners had been without food for forty-eight hours, 
and were desperate, without any matured plan. A few of them said, 'We may as well die in one way as another; let us break out of this horrible place.' Some of them wrested the guns from a relief of tifteen Rebel soldiers, just entering the yard, killing two who resisted, and wounding five or six others, and attempted to open the fence; but they had neither adequate tools nor concert of action. Before they could effect a breach, every gun of the garrison was turned on them. The field-pieces opened with grape and canister, and they dispersed to their quarters. In five minutes from its beginning the attempt was quelled, and hardly a prisoner was to be seen in the yard. The Rebels killed sixteen in all, and wounded sixty. Not one-tenth of the prisoners had taken part in the attempt; and many of them were ignorant of it until they heard the guns. Deliberate, cold-blooded murders of peaceable men, where there was no pretence that they were breaking any prison regulation, were very frequent.

"Our lives were never safe for one moment. Any sentinel, at any hour of the day or night, could deliberately shoot down any prisoner, or fire into a group of them, black or white, and never be taken off his post for it.

"I left about six thousand and five hundred remaining in garrison on the day of my escape, and they were then dying at the average rate of twentyeight per day, or thirteen per cent. a month. The simple truth is, that the Rebel authorities are murdering our soldiers at Salisbury by cold and hunger, while they might easily supply them with ample food 
and fuel. They are doing this systematically, and I believe are killing them intentionally, for the purpose either of forcing our Government to an exchange, or forcing our men into their own army."

The testimony of Mr. Brown, also a correspondent of the "Tribune," corroborates the above statements of $\mathrm{Mr}$. Richardson. He says :

"I have often wished that I could obtain a photograph of that room in Salisbury Prison; for I can give no idea of its repulsiveness and superlative squalor.

\section{ORIGINAL DESIGN OF SALISBURY PRISON.}

"The prison was formerly a cotton factory, about ninety by thirty feet; and when we were there, they had only six or seven hundred confined within its walls. A dirtier, smokier, drearier, and more unwholesome place I had never seen than the room in which we were placed. It reminded me of some old junk-shop in South street of the city I had left, and was hung round with filthy rags-tattered quilts and blankets, reeking with vermin, which the wretched inmates used as clothes and bed covering,-and thronged mostly with Northern and Southern citizens, most of whom were in garments long worn out, and as far remored from cleanliness as the wearers from happiness. In that abhorred abode we were compelled to eat and sleep as best we might. There were but two stoves, both old and broken, in the room; and they gave out no heat, but any quantity of smoke, which filled the apartment with bitter blueness. Vermin swarmed every where; they 
tortured us while we tried to sleep on our coarse blankets, and kept us in torment when awake. No light of any kind was furnished us; and there we sat night after night in the thick darkness, inhaling the foul vapors and the acrid smoke, longing for the morning, when we could again catch a glimpse of the orerarching sky.

\section{DEATII-LIFE.}

"Think of this death-life month after month! Think of men of delicate organization, accustomed to ease and luxury, of fine taste, and a passionate love for the beautiful, without a word of sympathy, or a whisper of hope, wearing their days out amid such scenes. Not a pleasant sound, nor a sweet odor, nor a vision of fairness, ever reached them. They were buried as completely as if they lay beneath the ruins of Pompeii or Herculaneum. They breathed mechanically, but were shut out from all that renders existence endurable. Every sense was shocked perpetually, and yet the heart, by a strange inconsistency, kept up its throbs, and preserved the physical being of a hundred and fifty wretched captives, who, no doubt, often prayed to die. Few persons can have any idea of a long imprisonment in the South. They usually regard it as an absence of freedom, a deprivation of the pleasures and excitements of ordinary life. They do not take into consideration the scant and miserable rations that no one, unless he be half-famished, can eat ; the necessity of going cold and hungry in the wet and wintry season; the constant torture from vermin, of which no care or caution 
can free one; the total isolation; the supreme dreariness, the dreadful monotony, the perpetual turning inward of the mind upon itself, the self-devouring of the heart, week after week, month after month, and sear after sear." 


\section{CHAPTER XXI.}

\section{AT ANDERSONVILle-" CAMP SUMTER."}

"IT is from no unfair motives that I am induced ,o make the following statement of what I saw and experienced while a prisoner in the hands of the Rebels during the spring, summer, and autumn of 1864. I have tried to give a truthful account of some of the cruelties and sufferings which our poor boys were called to endure in filthy, loathsome southern prisons and hospitals. It seems to me there can be no reason for any one to make a false report of the miseries we received at the hands of our heartless captors and brutal prison-keepers. To tell the truth of them is all that is needed to convince any reasonable man of their barbarities and fiendish attempt to deprive our soldiers, whom the fortune of war had thrown into their power, of every comfort and enjoyment of life.

\section{CAPTURE OF PLYMOUTH.}

"But to my narrative. I was captured April second, 1864, at Plymouth, North Carolina. It is to the credit of the Rebel soldiers whose good fortune it was to capture our command, stationed there to hold and defend the place, that we were treated with considerable courtesy and kindness while in 
their power. To my knowledge, no outrages were committed upon any of our white troops, though I beliere the small negro force with us fared very hard. Our men were allowed to retain their blan. kets and overcoats, and all little articles of value which they might have upon their persons. Many of the men had about them large sums of money, which they were allowed to keep.

\section{MARCII FROM PLYMOUTH TO TARBORO'.}

"From Plymouth a long and wearisome march was made to Tarboro', a very pretty town, situated on the Neuse, a few miles from Goldsboro'. By the time we arrived there the men were much fagged and worn out. The last day of the march we were without rations, and suffered a great deal from hunger and weariness. Soon after reaching our campingground, near the town, rations were issued to us. There were a few cow peas, or beans, more properly, some corn-meal, a small piece of bacon, and a very meagre allowance of salt, for each man. Some old iron kettles, tins, etc., were provided for us to cook our food in, and a small quantity of wood furnished; and we managed to prepare a repast which was very palatable to our well-whetted appetites. A system of trading was immediately commenced, which was carried on for a while very briskly, but was finally prohibited by the Rebel authorities. Our men would barter away their watches, rings, gold pen-holders, pocket-knives, coat-buttons, etc., for Confederate pone cakes, hard bread, and bacon, from the Rebels. The most exorbitant prices were 
demanded by both parties; our men, however, gen. erally getting the best bargain. We had remained at Tarboro' but a few days when orders were received to remove all the Union prisoners who could travel to Andersonville, Ga., immediately. Wé had already suffered much, both from hunger and exposure. Many were sick and feeble. All were anxious to leare, and we felt much relief at hearing that preparations had been made to remove us to a pleasanter and more firuitful portion of the Confederacy.

ANDERSONTILLE IN THE DISTANCE.

" We were informed that Camp Sumter, the prison to which we were going, occupied a delightful locality, and also that our food there would be more wholesome and plenteous than that which we had yet received. Their fair accounts and pleasing stories but increased our anxiety to be off; and it was with no little pleasure that, on the morning of April twenty-ninth, we bade adieu to the gloomy field into which we had been turned as so many brutes, and marched with quite joyous hearts to the dépôt in town. Here we were confined, crowded by forties into small and loathsome box-cars. Besides our own enormous numbers, six Rebel guards were stationed in each 'carriage'; a name which I heard applied by a foppish young officer to the miserable concern aboard which we were literally packed. Of course, the Rebels occupied the door's, and we nearly suffocated. Under such circumstances, many of the boys, less sanguine and hopeful than others, began to express doubts concerning the stories which 
we had heard; and intimated that they were al. mere fabrications to deceive us, and make it an easier matter to conrey us to Camp Sumter. Without doubt, such was the case. It is certain that they made the utmost efforts to get us through to the stockade at Andersonville under as small a guard as possible.

\section{ARRIVAL AT CHARLESTON.}

"We arrived in Charleston on Sunday morning, May first. To our great surprise, we found that some of the inhabitants of the city were friendly to us. They distributed tobacco and cigars among the men, and some secretly brought them food. Months afterwards, some of our suffering, dying boys found inestimable friends in the Sisters of Charity who abode in the city.

"Learing Charleston at an early hour in the afternoon, we were hurried on at quite a rapid rate toward Savannah, Georgia. About six o'clock in the evening it commenced storming very hard, and, being on platform cars, we were thoroughly drenched with rain.

"At about nine o'clock we changed cars a short distance from Savannah for Macon, at which place we arrived the following day a little past noon.

"I was much pleased with Macon. It is a handsome city, and pleasantly situated on the Ocmulgee River-a stream of some importance. It contained a number of fine residences, several churches, two or three large iron foundries, and a car-factory, I believe. Trees, flowers, and gardens presented an appearance not unlike that of early summer at home. 


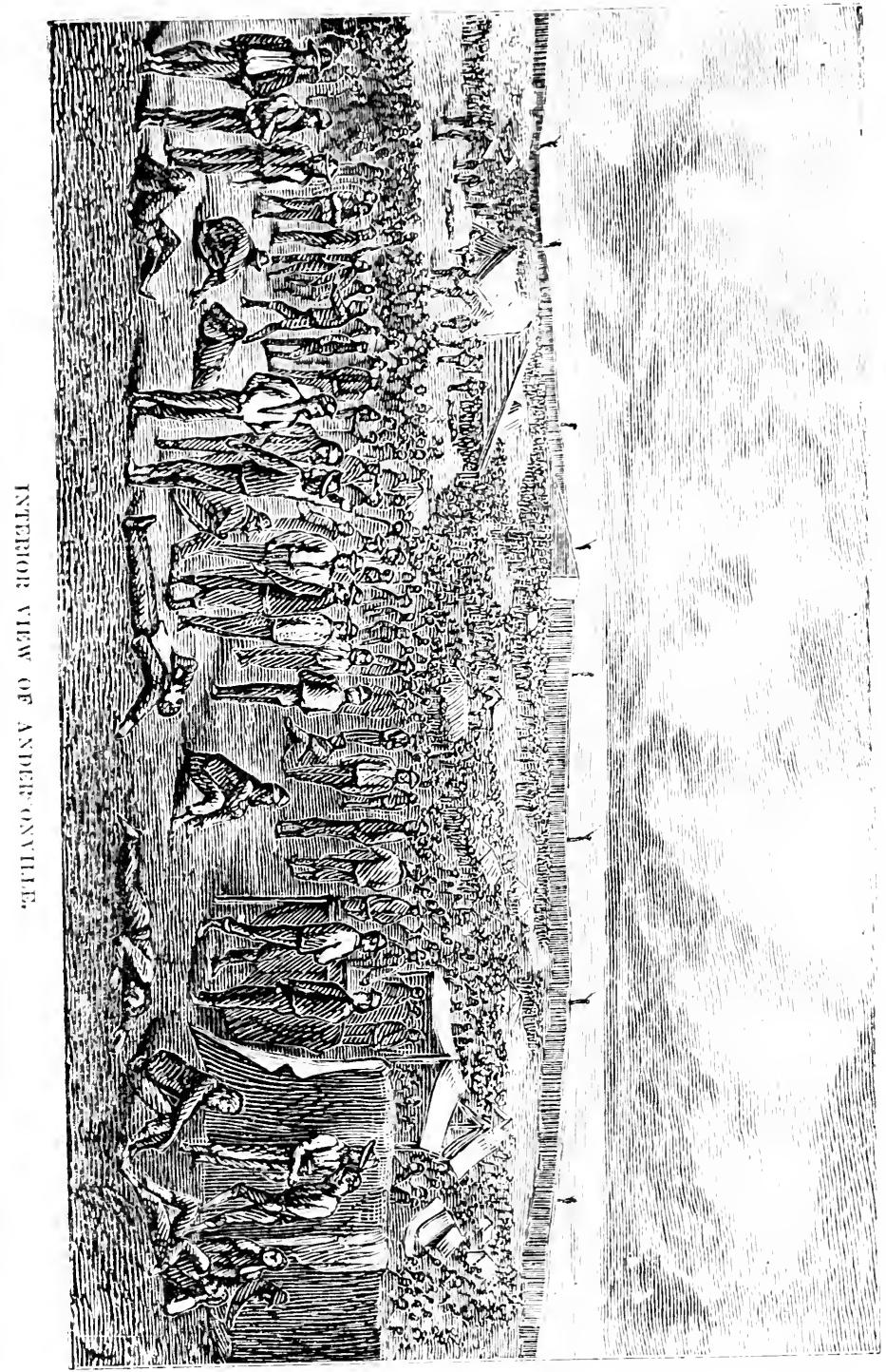



Almost everything there was looking pleasant and beautiful, and I felt very sad at leaving, knowing, as I then did, something of the true character of our future abode.

\section{ARRIVAL AT ANDERSONVIJLE.}

"Late in the afternoon of May second we left Macon on our way to Andersonville, at which place we arrived some time in the evening. Soon after our arrival there, we were marched into an open field near by, where we remained during the night. It being very cold, large fires had been made by the Rebel soldiers for our comfort. For this little act of kindness we indeed felt very grateful to them. The next morning, May third, a sinister-looking little foreigner came down to us, and, with considerable bluster and many oaths, began to form us into detachments, containing two hundred and seventy men each. These detachments were subdivided into messes of ninety each, and placed under the control of a sergeant, whose duty it was to attend roll-call, drawing rations, etc. At length, every thing being ready, we were escorted into the prison under a strong guard.

"It is impossible to describe our feelings at this time. Everywhere around us were men in the most abject wretchedness and misery. Immediately on our arrival among them they began to gather around us, and, in a very touching manner, related the sad story of their sufferings and wrongs. We could only sympathize with them. Beyond that, we could do nothing. We knew full well that the same cruelties which they had experienced were in store for us. The prospect before 
us was dark indeed. In the afternoon of the day on which I entered the prison, I ventured out some dis. tance into the camp. Everywhere was the most unmistakable evidence of intense suffering and destitution. Hundreds of the men were without shelter, and but very few had any comfortable clothing.

"The supply of wood was very small-scarcely enough to cook with; and the poor fellows were obliged to lie, night after night, week after week, on the cold, damp ground, without even a fire to warm themselves by.

"The Rebels may claim that there was some cause for not issuing a sufficient quantity of food to our prisoners at Andersonville; but for not granting us wood enough to keep us warm, and to cook with, there can be no apology. On three sides of the prison there was an immense woodland, from which all the wood that we needed could have been provided with very little difficulty. The same holds true in regard to shelter. I am persuaded that it was an act of premeditated inhumanity on the part of our enemies not to give us shelter. It would have required but a few weeks' time, and a few scores of hands, to have built barracks for our comfortless boys there, which would have been the means of saving hundreds of precious lives. If the Rebels would hare granted us even the rough, un-hern logs, and axes to work with, we would have built them ourselves.

"The camp at this time was in a most loathsome coundition. It then corered an area of about fifteen acres, and was enclosed by a high stockade, built of pine logs, hewn and closely joined together. 
"Upward of twenty feet from the stockade was the fatal dead-line, beyond which any poor feilow passing was almost certain to be fired upon by some of the ever-watchful sentries. In the centre of the camp, and extending entirely around it, was a broad ravine, which, toward the beginning of summer, became one of the filthiest places imaginable, and was one of the chief causes of the rast amount of sickness which existed during the months of July and August following. About this time, May 10th, the average rate of mortality daily, was upward of fifteen. It afterward rose as high as serenty-tive and one hundred.

\section{A JUST FATE.}

"Sunday, May fifteenth, a wretched cripple, who had the reputation about camp of being a very dangerous fellow, willing, for a double ration, to inform the Rebels of all plans made for escape which he might discover or accidentally hear of, was mortally rounded by a Rebel sentinel while on duty. For some unknown reason, the miserable man purposely passed beyond the dead line. The guard ordered him to go back; he refused to do so, and used some insulting language in reply. The sentry then fired upon him. He fell, horribly wounded, and lived only about two hours.

"Sunday, May twenty-second, a little incident of some note occurred in camp, to the great satisfaction of the well-disposed. It must be confessed that great demoralization prevailed among the prisoners. Quarrels and fights were of frequent occurrence.

"But the rrorst of all were the murderous deeds perpetrated by a desperate set of fellows, who had 
banded themselves together for the purpose of robbing the defenceless among them. From the sick and powerless they would steal blankets and pails for cooking in; and if a man was known to possess money, he was in danger of being deprived of it all, and possibly of his life besides. This morning one of the heartless scoundrels had been caught in the act of stealing from some one of his companions, and met with summary punishment. A part of his head and beard were shaven, and he was then exposed to the view of any who might wish to see him. After this he was turned over to the commandant of the prison, who immediately released him, but promised the men that in the future they might inflict what punishment they should deem proper on all whom they should catch engaged in robbing their comrades. The prime cause of all this demoralization among the men was the treatment they received at the hands of the Rebels. Had the Confederate authorities provided food in sufficient quantities for our men, and furnished other necessary comforts, it is altogether possible that no such deeds would have been committed in the camp; certainly they would have been very rare.

\section{RATIONS.}

"Toward the close of May our rations were 'cut down' fearfully. Starvation really began to stare us in the face. There were but few who were not suffering the pangs of hunger continually. Our daily allowance was only about half of a small loaf of corn bread, about four ounces of bacon, and a little ' $m u s h$ ' made of Indian meal partially cooked in water. 
"A portion of the camp drew raw rations, and fared somewhat better than those whose food was pre. pared before issued to them. Our food, when cooked outside, was always prepared in the most careless and indifferent manner. It not unfrequently occurred that even the meagre supply of bread which we did receive was sent in to us half cooked, and, when in this condition, it would become during the night totally unfit to eat.

"About the close of summer, cooked beans were issued to us. These were always in a most disgusting state, and could have been eaten only by starving men. There was always a copious supply of gravel, pods, and, what was still worse, bugs, in each man's allowance of this miserable fare.

\section{SUFFERINGS OF THE WOUNDED.}

"June third, a large number of wounded men were received at the camp, many of them in very destitute circumstances.

"But few, if any of them, were admitted to the hospital, though a large number had severe and painful wounds. Their sufferings became intense, almost unendurable. Without shelter during the day, they suffered indescribably from scorching, burning heat, and at night perhaps not less so from the cold. Mauy died. It could not be otherwise. Who but the merciless enemies of our country can be held accountable for this fiendish sacrifice of valuable lives?

"The morning of June ninth, a very unjust order was promulgated throughout camp. We had been permitted to send, nearly every day, a small squad of 
men from some of the detachments, under Rebel guards, into the woods near by, to procure some fuel for the camp, but it was now decided that no more should be allowed to go forward until they would solemnly pledge themselves not to attempt to escape while outside the stockade for that purpose; and if, after having given their pledge, they should violate it, the detachment to which they belonged should receive rations only every alternate day until the time that those who had escaped should be recaptured. To go without wood was impossible; to submit was the only way by which we could obtain it, and consequently we were under the necessity of yielding to the base demand.

"Sunday morning, June nineteenth, one of our men, unfortunately getting beyond the dead-line, was fired upon by the guard. He was missed, but the ball wounded two others, one severely.

"On the twenty-first, another man was shot while merely reaching beyond the dead-line for a small piece of wood which he needed.

BARBAROUS TREATHENT OF THE SICK.

"Toward the close of June, sickness and death began to prevail in eamp to an alarming extent. The men died by scores daily. But few were admitted to the hospital, and even when received there, it was not until life was nearly extinct. The old prisoners who had been incarcerated for months at Belle Island, were falling away with fearful rapidity. Nearly all those still living could see nothing before them but a slow, torturing death, from a most pain. 
ful disease, which had been caused by a want of proper food, and constant exposure. None can fully realize the intense agony, the horrid suspense and wretchedness, felt by these unfortunate men, but those who have had a like experience. Indeed, their sufferings were beyond description. Only a few conld receive medical treatment, and that scarcely worth mentioning, while in every part of camp were as brave and loyal soldiers as any that had ever taken up arms in defence of freedom, suffering and dying in a manner that might have shocked even the rude sensibilities of an American savage. It seemed that the more bitter our anguish became, the more delighted were our fiendish keepers. Not satisfied with the cruelties inflicted upon us, they even carried their animosities beyond this life, and declined to give a Christian burial to our dead. I will not now longer dwell upon this subject. It is too painful to contemplate.

"July thirteenth, one of the men, in attempting to procure some clean water to drink, passed a little beyond the dead-line, and was fired upon by two of the guards almost simultaneously. Both balls missed him, but took effect upon two other men, killing one of them immediately.

JOSEPH EGALF.

" $\Lambda$ bout the middle of July I was fortunate enough to make the acquaintance of a most excellent young man from Philadelphia, a member of the Seventh Pennsylvania Reserve Corps Volunteers, Joseph Egalf by name, who was actively engaged in caring for our neglected wounded men. From morning to night he 
went about dressing their wounds and ministering tc their wants, and was unremitting in his efforts to benefit and comfort them. All in suffering had his sympathy and compassion, and his aid, so far as it was in his power to render assistance. What finally became of him I do not know, but, should he be liv. ing, it is hoped something may be done to reward him handsomely for his many acts of love and kindness toward our poor boys who were with him at Ander. sonville.

"I find the following written in my diary undes date of July, twenty-fifth: "While walking in camr this morning, I observed several poor fellows lyins upon the ground, without shelter, blanket, coat, or even blouse-merely shirts and pants to protect them from the bitter cold of the past night.' There are a great many in camp in the same condition, and hun. dreds who are without shelter, blanket, and overcoat.

"To some it may seem incredible that it should be very cold during the night at this season of the year, but such was indeed the case.

"It may be asked, What became of the prisoners' clothing? I answer that, except in a few instances, it was stolen by the Rebels. Many a poor fellow can remember how unceremoniously he was stripped of almost every thing of value in his possession in an hour after his capture. Resistance was useless. To resist was to expose one's self to certain death. If a bare command would not bring a man out of his new boots, or induce him to give up his coat, a loaded pistol pointed at his head would.

"July twenty-seventh, another of our men was 
shot. He received a horrible wound in the head, and was carried out of camp in a dying condition.

"August fourth, still another was shot, receiving a severe wound through the body. August sixth, another cold-blooded murder was committed.

"One of the men, passing a little too near the stockade, was shot dead by a guard on duty. It had become dangerous to pass at the regular crossing. The sentinels seemed to be more vigilant than ever before in watching for opportunities to shoot down our poor unarmed men. No one was safe. No warning was given to a thoughtless intruder. The first thing one would know of his terrible condition after passing the fatal line, was a quick, sharp report, a groan, and all was over-another murder was committed. About the middle of August, the rate of mortality was about eight per day. Diarrhœa and scurry were the chief scourges of the camp. The fearful work of death was visible everywhere around us. I have frequently seen as many as thirty dead men lying in a row at the prison gate to be carried out for burial. It was sad, indescribably so, to see these brave men dying so far from home and its hallowed associations. No fond parents near to speak words of comfort and tenderness. None able to minister to their temporal necessities-none who could alleviate their sufferings. Alone they must writhe in the agonies of death, alone to die.

"It was under such circumstances of darkness and misery, that the shining truths of Christianity shone out before men in their unsurpassed glory and heavenly beauty. Many a freed, joyous spirit went from 
that foul, loathsome prison to immortal life and happiness.

"Thus far, only some of the physical sufferings consequent to our imprisonment have been briefly mentioned; it is now time to refer, for a few moments, to the

\section{INTENSE MENTAL TRIALS}

and afflictions which we prisoners experienced.

"In my diary, under date of August twenty-fourth, I find the following: "I believe the loss of health, exposure to privations, and physical sufferings consequent upon the manner of life in which we are now compelled to live, are not the saddest effects of our present captivity. But that which is the most lamentable is the mental debility which, under the present state of things, we must necessarily experience.' Again, 'The finer feelings-that which makes more lovely-as social being, love, affection, friendship, kindness, and courtesy -are being constantly deadened, rooted out from the heart, leaving it in a most woful condition.' Scarcely an hour in which anxiety about distant friends, suspense in regard to the future, and frequent despair, were not felt. It seems to me that the mind must have been in a state of trouble and anxiety nearly all of the time its frail tenement was suffering from confinement and disease. It was almost impossible to procure reading matter. Some of the soldiers had Bibles and Testaments, which were eagerly sought after and read by many of the men.

"It was with great difficulty one could think very attentively about other subjects than home and release from imprisonment. A topic for conversation 
might be introduced among a squad of men; perhaps they might talk about it for a few moments, but it would soon be dropped, and home, friends, and possibility or probability of exchange would come up for discussion. Men-brave men, indeed-became gloomy and despondent. Light faded from the once brilliant, fiery eye; the color disappeared from the manly countenance; manhood seemed to forget itself; the entire man was speedily drifting toward a fearful ruin. Hope had nearly vanished. The mind was laboring under intense agony. To some the burden was too much, and they have never recovered from its baneful effects. Others have nearly recovered, but the scars remain.

\section{REMOVAL OF PRISONERS FROM ANDERSONVILLE.}

"September seventh, the removal of the prisoners from Camp Sumter to other parts of the Confederacy was commenced. We were induced by the Rebel authorities to beliere that this unexpected movement was for a general exchange. With this belief our men could be sent away with only a small force guarding them, which was a consideration of no little importance with the Rebels just at that time.

"Suddenly stricken down with a violent attack of the scurvy, I was unable to leave with my detachment, and was left with the sick in camp. After suffering several days, I managed to get out with the first squad of sick which left for Florence, South Carolina. I was quite weak and feeble when I arrived at Florence, but a change of climate and diet rapidly improved my condition, and in a few days I was able 
to walk about without crutches. Soon afterward I was detailed as hospital steward, and paroled. From that time till my release, November thirtieth, my treatment was much better than it had been while I was at Camp Sumter. But in regard to that received by the thousands of poor fellows in the prison, there was but little apparent change. They suffered from cold and hunger perhaps more than while at Andersonville.

"I will here close my accounts of the sufferings of our friends. So far as I am concerned personally, I can forgive our bitter foes the cruelties which they have inflicted upon me. I do not desire revenge. That is farthest from my heart. God will punish them for their evil deeds. They have already suffered terribly. I feel that all should now try to do whatever they can to narrow the breach which exists between them and ourselres. I have always been glad our government so nobly declined to resort to retaliation. We cannot afford to be cruel. It is our highest honor to award good for evil.

"The magnanimity of our people is beyond question, and our enemies must acknowledge it. Our arms have conquered their proud hosts; our kindness must now subdue the enmity of their hearts. We must be neither too lenient nor too severe. To the leaders who precipitated us into four years of bloodshed and war, the severest punishment which the law can give; but to the poor misguided masses, that clemency which only a noble people are capable of exercising." 


\section{Tine Andersonville Post Office.}

[The following touching lines, descriptive of an incident in the Pen of the Union prisoners at Andersonville, Ga., are attributed to G. H. Hollister, Esq, of Litchfleld, Conn. The war has yet elicited nothing of sadder interest.]

No blanket round his wasted limbs,

Under the rainy sky he slept;

While pointing his envenomed shafts,

Around him Death, the archer, crept;

IIe dreamed of hunger, and held out

IIis hand to clutch a little bread,

That a white angel with a torch,

Among the living and the dead,

Seemed bearing, smiling as he went;

The vision waked him, as he spied

The post-boy followed by a crowd

Of famished prisoners, who cried

For letters-letters from their friends.

Crawling upon his hands and knees

He hears his own name called, and lo!

$A$ letter from his wife he sees!

Gasping for breath, he shricked aloud, And, lost in nature's blind eclipse,

Faltering amid the suppliant crowd,

Caught it and press'd it to his lips.

$\Lambda$ guard who followed, red and wroth,

And flourishing a rusty brand,

Reviled him with a taunting oath,

And snatched the letter from his hand.

"First pay the postage, whining wretch!"

Despair had made the prisoner brave,

"Then give me back my money, sir!

I am a captive-not a slave!

Yon took my money and my clothes;

Take my life too-but let me know

How Mary and the children are,

And I will bless you ere I go." 
The very moonlight through his hands

As he stood supplicating, shone,

And his sharp features shaped themselves

Into a prayer, and such a tone

Of anguish there was in his cry,

For wife and children, that the guard-

Thinking upon his own-passed by,

And left him swooning on the sward.

Beyond the "dead line" fell his head-

The eager sentry knew his mark,

And with a crash the bullet sped

Into his brain, and all was dark!

But when they turned his livid cbeek

Up toward the light, the pale lips smiled,

Kissing a picture fair and meek,

That held in either hand a child. 
RATIONS ISSUED BY THE UNITED STATES GOVERNMENT TO REBEL PRISONERS OF WAR. (Note the difference.)

Hard bread, . . . $14 \mathrm{oz}$. per one ration, or $18 \mathrm{oz}$. soft bread, one ration.

Corn meal, . . 18 oz. per one ration.

Beef, . . . . . 14 " " " "

Bacon or pork, . . 10 " " 6 " 6 "

Beans, . . . 6 qts. per 100 men.

Hominy or rice, . 8 lbs. " " "

Sugar, . . . . 44 " " " " " "

R. Coffee, . . . 5 "ground, or 7 lbs. raw, per 100 men. Tea, . . . . 18 oz. per 100 men.

Soap, • . • . . 4 " " " "

Adamantine candles, 5 candles per 100 men.

Tallow candles, . 6 6 " " " 6

Salt, . • . . . 2 qts. " " " "

Molasses, •. . 1 qt. " " " "

Potatoes, . . . $30 \mathrm{lbs}$. " " " "

STATEMENT OF CLOTHING ISSUED TO PRISONERS OF WAR AT FORT DELAWARE,

From Sept. 1st, 1863, to May 1st, 1861.

7,175 pairs Drawers (Canton flannel).

6,260 Shirts (flannel).

8,807 pairs woollen Stockings.

1,094 Jackets and Coats.

3,480 pairs Bootees.

1,310 pairs Trousers.

4,878 woollen Blankets.

2,680 Great Coats.

A verage number of prisoners, 4,489. 



\section{APPENDIX.}

Tue following Appendix is not as perfect as $\mathbf{I}$ could wish, it being very difficult to avoid errors in lists of this kind. The principal portion of the names were taken from the Rebel adjutant's book at Libby Prison, during the winter and spring of 1864, by Captain Fisher, to whom I have alluded in my Preface. I compiled the remainder while imprisoned at Columbia. The post-office address of the officers has been given, as far as they could be obtained.

Those marked thus (*) died during their imprisonment. 



\section{OFFICERS}

OF THE

\section{UNITED STATES ARMY AND NAVY,}

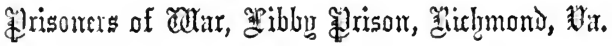

[This list comprises those officers who were imprisoned at Libby Prison during the winter and epring of 1864 . They were removed from Richmond to Danville in the early part of May, and from thence to Macon, Savannah, Charleston, Columbia, Charlotte, Raleigh, and Goldsboro'. The succecding list furnishes the additional captures of the summer and fall campaigns.]

\section{BRIGADIFE-GENERALS.}

Name.

Dow, Neal,

Scameron, O. P.,

Wessclle, H. W.,

Bartleson, F. A., Carlton, C. H., De Cesnola, P., Ely, Wm. G., Kindrick, W. P., Lawson, O. A. Le Favour, H., McClain, R. W., Powell, W. H., Rose, Thos. E.,
Regiment or Command.

1st Brig. 2d Div. 19 A. C., 3d Dept., W. Va.

Plymouth, N. C.,

COLONELS.

100th Ill. Infantry,

Chicago, IIl. 89th $O$. Infantry,

4th N. Y. Cavalry, 18th Conn. Infantry,

3d W. Tenn. Cavalry.

3d O. Infantry.

22d Mich. Infantry,

51st O. Infantry.

2d Va. Cavalry.

77th $\mathrm{Pa}$. Infantry,
Residence.

Portland, Me.

Washington, D. C.

- A small portion of the Libby prisoners were sent North for special exchange during the month of March, and a few succeeded to escaplog before we reached Georgla. 
Name.

Streight, A. D., Tilden, Chas. W., Tippin, A. H., Wilson, W. T.,

Archer, S. MI., Boyd, I. F., Carada, F. F., Farnsworth, C., Glenn, W. A., Hays, E. In, Henry, A. P., Hunter, H. B., Irvine, Wm., Johnson, O. C., Joslin, G. C., Lasselle W. P., Lichficld, A C., Martin, C. H., Mayhew, J. D., McCreary, W. B., McHolland, D. A., McMackin, W. O., Miles, D., Nichols, Mr., Northcott, R. S., Piper, P. S., Polsley, I. J., Price, $\mathrm{Wm}$. Robert, H. C., Rogers, A. F., Sanderson, J. M., Spofford, J. T., Von Helmrich, G., Von Schrader, A, Walker, J. N., Wcet, T. S.,
Regiment or Comrnand. 51st Ind. Infantry, 16th Me. Infantry. 68th $\mathrm{Pa}$. Infantry, 123d O. Infantry.
Residence.

Indianapolis, Ind.

Philadelphia, Pa.

\section{LIEUTENANT COLONELS.}

17th Io. Infantry,

20th Army Corps.

114th $\mathrm{Pa}$. Infantry.

1st Conn. Cavalry,

89th O. Infantry.

100th O. Infantry,

15th Ky. Cavalry.

123d O. Infantry.

10th N. Y. Cavalry, 15th Wis. Infantry.

15th Mass. Infantrs,

9th Md. Infantry.

7th Mich. Cavalry,

84th IIl. Infantry.

Sth Ky. Infantry.

21st Mich. Infantry,

s1st Ind. Infantry.

21st Ill. Infantry.

79th $\mathrm{Pa}$ Infantry.

18th Conn. Infuntry,

12th $\nabla a$ Infantry.

77th $\mathrm{Pa}$ Infantry.

8th $\nabla$ a. Infantry.

139th Va. Militia.

21st Wis. Infantry.

80 th IIl. Infantry.

79th N. Y. Infantry,

4th Mro. Cavalry,

A. I. Gen. U. S. Vols

73d Ind. Infantry.

24th Wis. Infantry,
Indianapolis, Ind.

Philadelphia, $\mathbf{P a}$. Hartford, Conn.

Columbas, 0.

Albany, N. Y.

Boston, Mass.

Grand Rapids, Mich.

Flint, Mich.

Hartford, Conn.

Brooklyn, N. Y. Little Falls, N. Y. St. Louis, Mo.

Racine, Wis. 
Name.

Williams, J., Wing, I. H.,

Bates, E. N., Beatley, W. T., Beers, C. H., Bogle, A. Carpenter, D. A., Clarke, M. E., Cooke, E. F., Collins, J. P., Edwards, J. J., Fitzsimmons, G. W., Goff, N., jr., Hall, J., Henry, J., Hill, J. B., Hooper, J. H., Johnson, H. I., Kercher, D. M., Kovax, S., Marsh, S., Marshall, W. S., McDonald, B. B., McIrvin, S., McMahan, A., Moore, M., Morton, W. D., Mublman, J. R., Neeper, W. P., Owens, W. N., Pasco, H. L., Phelps, L. N., Phillips, A, Pope, E. M., Rodgers, T. B., Russell, W. I.,
Regiment or Command. 25th O. Infantry. 3d O. Infantry.

MAJORS.

80th Ill. Infantry, $2 d$ O. Infantry. 16th Ill. Cavalry. 35th U. S. C. T., 2d Tenn. Cavalry. 5th Mich. Cavalry, 2d N. Y. Cavalry, 29th Ind. Infantry. 32d Mass. Infantry. 30th Ind. Infantry. 4th W. Va. Cavalry, 1st Va. Cavalry. 5th O. Cavalry. 17th Mass. Infantry, 15th Mass. Infantry, 11th Tenn. Infantry. 10th Wis. Infantry. 54th N. Y. Infantry, 5th Md. Infantry. 5th Ia. Infantry. 101st O. Infantry. 2d N. Y. Cavalry, 21st O. Infantry. 29th Ind. Infantry. 14th N. Y. Cavalry, A. A. Gen. U. S. Vols., 57th $\mathrm{Pa}$. Infantry, 1st Ky. Cavalry, 16th Conn. Infantry, 5th Va. Infantry. 77th $\mathrm{Pa}$ Infantry. 8th N. Y. Cavalry, 140th $\mathrm{Pa}$. Infantry.

A. A. Gen. U. S. Vols., Albany, N. Y.
Chicago, IIl.

Boston, Mass.

Ann Arbor, Mich.

Deckartown, N. J.

Wurtemberg, W. Va

Chelsea, Mass.

Boston, Mass.

New York City.

Lafajette, Ind.

Brooklyn, N. Y. Woodburn, Ill. Pittsbargh, $\mathbf{P a}$. Somerset, Ky. Hartford, Conn.

Rochester, N. Y. 
Name.

Stewart, A,

Vananda, I. C.,

Von Witzel, A,

Wade, J. B.,

White, H. A.

White, Harry,

Adams, S. B.,

Adams, W. Ro,

Adams, C. A

Airey, W.,

Alban, H. H.,

Albright, J.,

Aldrich, C. S.,

Alexander, E. C.,

Allen, S.,

Armstrong, W. F.,

Arthurs, S. C.,

Arthur, J. A.,

Atwood, E W.,

Avery, W. B.,

Baas, E.,

Bailey, D. I.,

Baldwin, MI. R.,

Banks, B. V.,

Bascom, E. B.,

Barton, J. H.,

Barton, F.,

Barritt, D. M.,

Barnes, J. W.,

Beale, E.,

Beeman, W. M.,

Bender, W. P.,

Bending, H. R.,

Benner, H. S.,

Berry, A,

Bigelow, A. J.,
Regiment or Command.

A. A. Gen. U. S. Vols.,

3d O. Infantry.

74th $\mathrm{Pa}$. Infantry.

73d Ind. Infantry.

13th $\mathrm{Pa}$. Cavalry.

67th Pa. Infantry,

\section{CAPTAINS.}

85th N. Y. Veterans.

89th O. Infantry.

1st Vt. Cavalry,

15th $\mathrm{Pa}$. Cavalry,

21st 0 . Infantry.

87th $\mathrm{Pa}$. Cavalry.

85th N. Y. Infantry,

1st Del. Infantry.

85 th N. Y. Veterans,

74th O. Infantry.

67th $\mathrm{Pa}$. Infantry,

8th Ky. Cavalry.

16th Me. Infantry.

$132 d \mathrm{~N}$. Y. Infantry.

20th Ill. Infantry.

99th N. Y. Infantry.

2d Wis. Infantry.

13th Ky. Infantry.

5th Ia. Infantry.

1st Ky. Cavalry.

10th Mass. Infantry,

89th O. Infantry.

$83 d$ N. Y. Infantry.

8th Tenn. Infantry.

1st Va. Cavalry.

123d O. Infantry.

61st O. Infantry,

101st Pa. Infantry,

3d Md. Cavalry,

79th Ill. Infantry.
Residence.

Uniontown, $\mathbf{P e}$

Indiana, $\mathbf{P a}$.

Wallingford, Vt.

Philadelphia, $\mathbf{P a}$.

Canandaigua, N. $\mathbf{Y}$.

Black Creek, N. Y.

Brookville, Pa.

Boston, Mass.

Circleville, 0.

Gettysbarg, $\mathbf{P a}$

Baltimore, Ma. 
Name.

Bird, John,

Birch, J.,

Blinn, L. D.,

Bohannan, D. E.,

Boltz, W. K.,

Borgess, L. T.,

Bowers, G. W.,

Boyd, M.

Brown, C. D.,

Brown, J. A,

Burke, T. F.,

Bush, J. G.,

Byron, Chas.,

Carley, A.,

Casker, II.,

Carroll, J.,

Carpenter, J. C.,

Casler, B. G.,

Campbell, B. F.,

Canfield, S. S.,

Canton, Miles.

Callahan, Mr.,

Carns, M. C.,

Calhonn, A. R,

Cartwright, A. G.,

Charlier, E.,

Christopher, Jno.,

Chamberlin, J. W.,

Clarke, T.,

Clark, J. A.,

Clark, M. L.,

Clapp, J. B.,

Coats, H. A.,

Conrad, W. F.,

Comee, C. C.,

Cornwall, R.T.,

Cochran, M. A.,

Cochran, W. N.,

Collins, W. A.,
Regiment or Command.

14th $\mathrm{Pa}$. Cavalry.

42d Ind. Infantry.

100th O. Infantry.

3d Tenn. Cavalry.

1s1st $\mathrm{Pa}$. Infantry.

67th $\mathrm{Pa}$. Infantry,

101st $\mathrm{Pa}$ Infantry,

73d Ind. Infantry.

18th Conn. Infantry.

85th N. Y. Veterans,

16th Conn. Infantry,

16th IIl. Cavalry.

8d O. Infantry,

73d Ind. Infantry.

1st N. Y. Cavalry.

5th IId. Infantry.

67th $\mathrm{Pa}$ Infantry.

154th N. Y. Infantry, East Randolph, N. Y.

39th IIl. Infantry.

21st O. Infantry.

21st 0 . Infantry.

9th MI. Infantry.

3d Tenn. Infantry.

1st $\mathrm{Ky}$. Cavalry,

85th N. Y. Veterans,

157th N. Y. Infantry,

16th U. S. Infantry.

123d O. Infantry.

79th IIl. Infantry.

7th Mich. Cavalry.

101st $\mathrm{Pa}$. Infantry,

16th Conn. Infantry,

85th N. Y. Veterans,

25th Ia. Infantry.

94th N. Y. Infantry.

67th $\mathrm{Pa}$. Infantry.

16th U. S. Infantry.

42d III. Infantry.

10th Wis. Infantry.

Residence.
Dyberry, $\mathrm{Pa}$

Pittsburgh, Pa.

Wellsville, N. Y.

Hartford, Conn.

Lenox, 0.

-Louisville, $\mathbf{K}$.

Phillips Creek, N. Y.

New York City.

Mansfleld, $\mathrm{Pa}$.

Wellsville, N. Y.
Wethersfleld, Conn. 


\section{Name.}

Connover, S. D., Conway, W. E., Copeland, J. R., Compher, A., Cratty, E. G., Craig, Jno., Crocker, G. A., Cummins, T., Cummins, J. P., Curd, R. S., Cusac, J., Cutler, Jno., Davis, H. C., Davis, G. C., Day, R. H., Day, E. jr., Deang, W. N., Dillion, F. W., Dietz, H., Dinsmore, R., Dillingham, E., Dirks, F. C., Donaghy, J., Domschke, B., Doten, F. B., Douglass, W. H., Driscoll, E. M., Dance, Jno., Dunshane, J. M., Dunn, E. J., Dygert, K. S., Eastmond, O., Eberheart, H. H., Eglin, A., Ewen, M., Ewing, S. II., Evers, B. F., Fay, J. B., Field, A.;
Regiment or Command. 121st IIl. Infantry, 9th Mrd. Infantry. 7th O. Cavalry. 101st $\mathrm{Pa}$. Infantry, 103d $\mathrm{Pa}$. Infantry, 1st Va. Cavalry, 5th N. Y. Cavalry. 19th U. S. Infantry. 9th Md. Infantry. 11th Ky. Cavalry. 21st O. Infantry. 34th O. Infantry. 1Sth Conn. Infantry, 4th Me. Infantry. 56th $\mathrm{Pa}$. Infantry. 89th 0. Infantry, 51st Ind. Infantry. 1st Ky. Cavalry. 45th N. Y. Infantry, 5th $\mathrm{Pa}$. Infantry. 10th Va. Infantry. 1st Tenn. Infantry. 103d Pa. Infantry, 26th Wis. Infantry, 14th Conn. Infantry.

A. C. S. U. S. Vols. 3d O. Infantry. A. D. C. U. S. Vols. 142d N. Y. Infantry. 1st Tenn. Cavalry. 16th Mich. Infantry. 1st N. C. U. S. Infantry, 120th O. Infantry, 45th 0 . Infantry. 21st Wis. Infantry, 26th O. Infantry. 100th O. Infantry. 154th N. Y. Infantry. 94th N. Y. Infantry,
Residence.

Squaw Village, N. J

Ramsburg, Pa. Butler, $\mathbf{P a}$.

Wheeling, W. Va.
Bainbridge, 0 .

New York City.

Allegheny City, Pa Milwaukee, Wis.

Clncinnati, $\mathrm{O}$.
New York City. Wooster, 0.

Fond Du Lac, Wis.

Weedsport, N. Y. 
Name.

Fisk, J. E.,

Fischer, B. F.,

Flinn, Jno. M.,

Fobes, E. A.,

Forrester, W.,

Foster, J. W.,

Frey, E.,

Freeman, D. W. D.,

Galbraith, A. G.,

Gallagher, M.,

Gallaher, J. F.,

Gates, J.,

Gateh, O. C.,

Galt, Jas.,

Getman, Di.,

Gimber, H. W.,

Glenn, S. A.,

Goetz, J.,

Gordon, G. C.,

Gray, W. L.,

Grafton, B.,

Green, J. H.,

Green, G. W.,

Gregg, H. H.,

Grose, J. W.,

Gustaveson, Chas.,

Hay, Daniel,

Hagler, J. G.,

Haack, A.,

Hamlin, S. G.,

Hart, P. H.,

Hart, V. K.

Hant, W. W.,

Hasty, Chas.,

Hamilton, A. G.,

Handy, T.,

Harkness, R.,

Hawkins, H. E.,

Hayee, A. H.,
Regiment or Command.

2d Mass. Artillery,

51st Ind. Infantry.

A. C. S. U. S. Vols.

24th O. Infantry.

42d Ill. Infantry,

82d IIl. Infantry.

101st Pa, Infantry,

22d Mich. Infantry,

2d N. J. Cavalry.

2d 0 . Infantry.

33d O. Infantry.

89th 0. Infantry,

A. Q. M. U. S. Vols. 10th N. Y. Cavalry,

150th $\mathrm{Pa}$. Infantry,

89th O. Infantry,

22d Mich. Infantry,

24th Mich. Infantry,

151st Pa. Infantry.

64th 0. Infantry,

100th 0. Infantry,

19th Ind. Infantry,

13th $\mathrm{Pa}$ Cavalry,

18th Ky. Infantry.

15th Wis. Infantry.

80th Ill. Infantry.

5th Tenn. Infantry.

18th N. Y. Infantry.

134th N. Y. Infantry,

19th Ind. Infantry,

19th U. S. Infantry.

100th O. Infantry.

2d N. Y. Cavalry,

12th Ky. Infantry.

79th Ill. Infantry.

10th Wis. Infantry.

7Sth IIl. Infantry,

7th Tenn. Cavalry,
Residence.

Grantville, Mass.

Belvidere, III.

Irish Ripple, $\mathrm{Pa}$

Lexington, Mich.

Millford, 0 .

Mayfield, N. $\mathbf{Y}$.

Philadelphia, $\mathrm{Pa}$.

Hillsboro', $\mathbf{O}$.

Mount Clemens, Mich.

Detroit, Mich.

Marion, 0.

Fremont, 0.

Muncie, Ind.

Philadelphia, $\mathbf{P a}$.

Schenectady, N. Y.

Edensburg, Ind.

Lafayette, Ind.

Coastbury, IIl.

Lovington, Tenn. 
Name.

Harns, W., Heyer," A. MI., Hendricks, J., Heil, J., Heffey, A, Herold, J. B., Hetsler, J. W., Hertzog, R. H. O., Hescock, H., Hintz, H., Hock, R. B., Holt, W. C., Honeycutt, S. C., Hodge, A., Hubbell, W. L., Huntley, C. C., Imbric, J. M., Irsch, F., Irwin, S., Ires, R. O., Jackson, J. S., Jennings, J. T., Jones, S. F. Jones, D. I., Johnson, R., Johnson, J. C., Johnson, J. MI., Johnson, J. A., Joselyn, F. R, Kendall, W. M., Keeler, A. M., Eelly, D. A. Kelly, J., Kelly, D. F., Kennedy, J., King, S. B., Eoch, E. MI., Krause, J., Laud, J. R.,
Regiment or Command. 24th MIo. Caralry, 10th Va. Cavalry. 1st N. Y. Cavalry. 45th N. Y. Infantry, 142d $\mathrm{Pa}$ Infantry, 9th MI. Infantry. 9th O. Calvalry, 1st N. Y. Caralry, 1st Mo. Artillery, 16th Conn. Infantry, 12th N. Y. Cavalry, 6th Tenn. Infantry, 2d E. Tenn. Infantry. 80th III. Infantry, 17th Conn. Infantry. 16th Iil. Infantry, 3d 0. Infantry, 45th N. Y. Infantry, 3d Ia. Infantry. 10th Mass. Infantry, 22d IIl. Infantry, 45th 0 . Infantry, 80th IIl. Infantry, 18t Ky. Cavalry. 6th N. Y. Cavalry, 149th Pa. Infantry, 6th Ky. Infantry. 11th Ky. Cavalry. 11th Mass. Infantry, 73d Ind. Infantry, 22d Mich. Infantry, 1st Ky. Cavalry. 73d $\mathrm{Pa}$. Infantry. 73d Pa. Infantry. 73d $\mathrm{Pa}$ Infantry. 12th $\mathrm{Pa}$ Cavalry, 5th IId Infantry. 3d Pa Artillery. 66 th Ind. Infantry,
Residence.

Mount Vernon, Ma

New York City.

Berlin, $\mathrm{Pa}$

Calvina, 0.

New York City.

St. Louis, Mo.

Hartford, Conn.

New York City.

Trenton, Tenn.

Fosterbury, Ill.

Springfield, 11 .

Wellsville, 0.

New York City.

Rochester, N. Y.

Salem, Ill.

Kenton, 0.

Jones' Creek, IIL.

Ogdensburgh, N. Y. Couder's Post, Pa

Boston, Mass. Plymonth, Ind. Disco, Mich.

New Haren, Conn.

Leavenworth, Ind. 
Name.

Lee, E. M.,

Lewis, J. W.,

Lounsberry, R. F.,

Lovett, L. P.,

Love, J. E.,

Loyd, J. K.,

Lucas, John,

Lucas, W. D.,

Mattherson," E. J.,

Martins, W. F.,

Marsh, P.,

Marsh, S.,

Mann, C. A.,

Mass, E. A.,

Makepeace, A. J.,

Mason, H. H.,

Marney, A,

Martin, J. C.,

Mackey, J. F.,

Manning, G. A.,

McComas, J. M.,

McDowell, J. S.,

McGinnis," W.,

McGuiddy, H. C.,

McHolland, D. A,

McKee," S.,

McMahon, J.,

McMoor,

McRoberts, J. B.,

Meany, D. B.,

Mennert, F.,

Metcalf, C. W.,

Metcalf, A. W.,

Meade, S.,

Meager, J.,

Milsaps, M. R.,

Noses, C. C.,

Morris, W. M.,

Moore, G. W.,
Regiment or Command.

5th Mich. Cavalry.

4th Ky. Cavalry.

10th N. Y. Cavalry.

sth Ky. Infantry.

8th $\mathrm{Ky}$. Infantry,

17th Mass. Infantry,

5th Ey. Infantry.

5th N. Y. Cavalry,

18th Conn. Infantry,

14th Mass. Artillery.

67th $\mathrm{Pa}$ Infantry.

5th Md. Infantry.

5th IIl. Cavalry.

8sth $\mathrm{Pa}$ Infantry.

19th Ind. Infantry,

2d N. Y. Cavalry,

2d E. Tenn. Infantry.

1st Tenn. Artillery.

103d $\mathrm{Pa}$. Infantry,

2d Mass. Cavalry,

9th Md. Infantry.

77th $\mathrm{Pa}$. Infantry.

74th IIl. Infantry.

1st Tenn. Cavalry.

51st Ind. Infantry,

14th Ky. Cavalry.

94th N. Y. Infantry,

29th Ind. Infantry.

3d O. Infantry.

13th $\mathrm{Pa}$ Cavalry,

5th Md. Infantry.

42d Ind. Infantry,

14th N. Y. Cavalry.

111th N. Y. Infantry,

40th 0 . Infantry.

2d E. Tenn.

6sth $\mathrm{Pa}$. Infantry.

93d III. Infantry.

7th Tenn. Infantry,
Residence.

St. Lonis, Mo.

Boston, Mass.

East Gainsville, N. Y.

Dixon, Conn.

Anderson, Ind.

Lafayette, Ind.

Clarion, $\mathrm{Pa}$

Oldtown, Mass.

Adriance, Ind.

Titusville, $\mathrm{Pa}$.

Philadelphia, $\mathbf{P a}$

Dale, Ind.

Moravia, N. Y.

Covington, Tenn. 
Name.

Mooney, A. H.,

Mall, D. H., Mullin, D. W.,

Murray, W. M.,

Noble, H.,

Noel, W. A.,

O'Brien, E.,

Olcott, T. W.,

Ottinger, W.,

Pace, N. C.,

Patterson, F. A.,

Page, J. E.,

Parmalee, J. A.

Pennypacker, E. J.,

Perry, F. W.,

Pennfield, J. A,

Phelps, J. D.,

Pillsbury, S. H.,

Pierce, G. S.,

Pickerill, W. F.,

Place, F.,

Porter, J. F.,

Porter, A.,

Poole, S. V.,

Pollock, R.,

Poston, J. L.,

Randolph, J. F.,

Randolph, N. S.,

Reed, P. C.,

Reed, Thos.,

Reynolds, C.,

Richley, J. A.,

Riggs, C. H.,

Riggs, B. F.,

Rice, J. A.,

Robbins, A.,

Rossman, W. C.,

Rosenbaum, O. H.,
Regiment or Command.

16th N. Y. Cavalry,

73d Ind. Infantry.

101st Pa. Infantry,

2d E. Tenn. Infantry.

9th MId. Infantry.

5th Md. Infantry.

29th Mo. Infantry,

134th N. Y. Infantry,

8th Tenn. Infantry.

80th III. Infantry.

3d Va. Cavalry.

5th Ia. Infantry,

7th Ind. Infantry,

18th Pa. Cavalry,

10th Wis. Infantry,

5th N. Y. Cavalry,

73d Ind. Infantry.

5th Me. Infantry,

19th U.S. Infantry,

5th Ia. Infantry.

157th N. Y. Infantry.

154th N. Y. Infantrs.

154th N. Y. Infantry,

154th N. Y. Infantry,

14th Pa. Infantry.

13th Tenn. Infantry,

123d O. Infantry.

2d Mo. Infantry.

3d O. Infantry,

1st Va. Infantry.

8th Tenn. Infantry.

73d Ind. Infantry.

123d O. Infantry.

18th Ky. Infantry.

73d Ill. Infantry,

123d O. Infantry.

3d O. Infantry,

123d O. Infantry,
Residence.

Plattsburg, N. Y.

Bedford, $\mathrm{Pa}$.

Cape Girardeau, Mo.

Cherry Valley, N. Y.

Iowa City, Iowa.

Valparaiso, Ind.

Philadelphia, $\mathrm{Pa}$.

Menasha, Wis.

Crown Point, N. Y.

Biddeford, Me.

Dabaque, Iowa.

Olean, N. Y.

Springfield, N. Y.

Cageville, Tenn.

Hamilton, $\mathrm{O}$.

Harrisburg, Ill.

Hamilton, $\mathbf{O}$.

Sandusky City, 0. 
Name.

Rowan, C.,

Rowan, W.,

Rollins, M.,

Rose, J. C.,

Robinson, W. A.,

Robinson, T. B.,

Robb, W. J.,

Rodgers, A.,

Robins, W. H.,

Robb, W. J.,

Russell, M.,

Russell, J. A.,

Ryder, S. B.,

Samson, I. B.,

Sawyer, H. W.,

Schofield, R,

Schell, Geo. L.,

Schemmerhorn, J. A.,

Schirtz, D.,

Schroade, J. C.,

Scott, P. S.,

Searce, W. W.,

Senter, A. P.,

Singer, J. P.,

Shaefer, Jas.,

Shepherd, E. A.,

Shoemaker, E. M.,

Smith, E. L.,

Smith, D. D.,

Smullin, F.,

Spencer, R. H.,

Spencer, S. A.,

Starkweather, W. I.,

Stover, J. C.,

Starr, G. H.,

Stone, J. R.,

Stanton, A. H.,

Bwayzie, W. A.,
Regiment or Command.

96th Ill. Infantry.

Indpt. Cavalry.

2d Wis. Infantry.

4th Mo. Cavalry.

77th Ia. Infantry.

16th Conn. Infantry,

1st Va. Infantry,

4th Ky. Cavalry,

2d E. Tenn. Infantry.

1st W. Va. Infantry,

51st Ind. Infantry.

93d IIl. Infantry,

5th N. Y. Cavalry,

2d Mass. H. Artillery,

1st N. J. Cavalry.

1st. Vt. Cavalry,

8sth Pa. Infantry,

112th Ind. Infantry.

12th Pa. Cavalry.

77th $\mathrm{Pa}$. Infantry.

80th IIl. Infantry.

51st Ind. Infantry.

2d E. Tenn. Infantry.

33d O. Infantry.

101st $\mathrm{Pa}$. Infantry,

110th 0. Infantry.

100th O. Infantry,

19th U. S. Infantry.

1st Tenn. Cavalry.

103d $\mathrm{Pa}$. Infantry,

10th Wis. Infantry.

82d O. Infantry.

85th N. Y. Infantry,

3d Tenn. Infantry.

104th N. Y. Infantry,

157th N. Y. Infantry.

16th U. S. Infantry.

3d O. Infantry,
Residence.

Bristol, Conn.

Wheeling, W. Va.

Louisville, Ky.

Wheeling, W. Va.

Neponset, Ill.

Arbane, N. Y.

Springfield, Mass.

Brattleboro', Vt.

Philadelphia, $\mathbf{P a}$.

Lancaster, $\mathbf{P a}$.

Carlisle, $\mathrm{Pa}$.

Waterville, $\mathbf{O}$.

Oakland, Pa.

Orlean, N. Y.

Rochester, N. Y.

Columbus, 0. 
Name.

Syring, Wm.,

Szabad, E.,

Talor, H. D.,

Teed, John,

Templeton, 0 .,

Ten Eyck, T.,

Thornton, T.,

Thornton, T.,

Thompson, B. E.,

Tubbs, A.,

Turner, M. C.,

Underdown, J. D.,

Urquhard, S. A,

Urwiler, G. C.,

Vanderhoef, J. W.,

Van Buren, G. M.,

Walleck, Wm.,

Warren, G. W.,

TVands, H. P.,

Wentworth, T. E.,

Wellsheimer, P.,

Wheeler, J. D.,

Whcelan, J. H.,

White, C. W.,

White, H. C.,

White, Geo. Mr.,

Whiteside, J. C.,

Whitney, M. G.,

Wilson, $\mathrm{A}$,

Wilson, A. C.,

Willetts, W.,

Williams, J. G.,

Williams, W. H.

Wistlake, J. A.,

Widdis, C. C.,

Wicker, W. B.,

Wilkins, J. E.,

Wild, J. G.,

Wolcott, E. A.,
Regiment or Command.

45th N. Y. Infantry.

A. D. C. U. S. Vols., 116th 0 . Infantry.

110th. Pa. Infantry.

107th $\mathrm{Pa}$. Infantry.

18th U. S. Infantry.

5th U. S. Infantry.

161st N. Y. Infantry.

A. D. C. D. S. Vols.

9th Ky, Cavalry.

16th Conn. Infantry,

$2 d \mathrm{E}$. Tenn. Infantry.

A. C. S. U. S. Vols.

67th $\mathrm{Pa}$ Infantry.

45th $\mathrm{N}$. Y. Infantry.

6th N. Y. Cavalry,

51st Ind. Infantry.

18th Conn. Infantry.

22d Mich. Cavalry,

16th Me. Infantry.

21st III. Infantry,

15th Conn. Infantry,

A. Q. MI. U. S. Vols.

3d Va. Cavalry,

94th N. Y. Infantry,

1st Va. Infantry,

94th N. Y. Infantry,

29th Mo. Infantry.

80th IIl. Infantry.

104th N. Y. Infantry,

7th Mich. Infantry,

51st III. Infantry.

4th N. Y. Cavalry,

73d Ind. Infantry.

150th $\mathrm{Pa}$. Infantry,

21st 0 . Infantry.

112th III. Infantry.

9th N. Y. Cavalry.

16th II. Infantry.
Residence.

Washington, D. C.

Hartford, Conn.

Washington, D. C.

St. Clair, Mich.

Neoga, Ill.

New Haven, Conn.

Baltimore, Md.

Lysander, N. Y.

Wellsburg, W. Va.

Wroming, N. Y.

Spencer, Mass.

Birmingham, Mich.

Albany, N. Y.

Germantown, $\mathrm{Pa}$ 
Name.

Wright, W. R., Zeis, H.,

Regiment or Command.

soth Ill. Infantry.

soth Ill. Infantry.

\section{LIEUTENANTS.}

Abernathy, H. C., Acker, G. D., Adams, Jas., Adam8, H. W., Adair, W. A, Ahern, M., Ahlert, J. H., Alstacd, C. L., Albro, S. A., Allee, A, Albin, I. S., Allen, R. J., Allender, W. F., Alger, A. B., Anderson, R. W., Anderson, H. M., Anderson, C. L., Andrews, E. E., Andrews, S. T., Andrus, W. R. Anshutz, H. F., Appel, H., Armstrong, T. S., Atkin, P., Austin, J. W., Barlow, J. W., Barnes, O. P., Bailey, G. W., Babb, Jno. D., Bath, H., Bath, W., Barclay, C. T., Bartram, D. S., Ballard, \$. H., 16th Ill. Cavalry, 123d 0 . Infantry, 80th Ill. Infantry, 37th IIl. Infantry, 51st Ind. Infantry, 10th $\mathrm{Va}$. Infantry. 45th N. Y. Infantry, 54th N. Y. Infantry, 80th IIl. Infantry, 16th Ill. Cavalry, 79th Ill. Infantry, $2 d \mathrm{E}$. Tenn. Infantry. 7th Tenn. Cavalry. 122d 0 . Infantry, sd Me. Infantry. 3d Ia. Infantry. 22d Mich. Infantry, 85th N. Y. Veterans, 16th Conn. Infantry, 12th Va. Infantry, 1st Md. Cavalry, 122d O. Infantry, $2 d \mathrm{E}$. Tenn. Infantry. 5th Ia. Infantry, 51st Md. Infantry, 3d O. Infantry, 3d O. Infantry. 5th Md. Infantrs. 45th N. Y. Infantry, $132 d$ N. Y. Infantry. 149th Pa. Infantry. 17th Conn. Infantry, 6th Mich. Cavalry, 22d 0. Battery,
Residence.

Paris, Mo.

Fostoria, 0.

Nashville, $\amalg$.

Frankfort, IIl.

North Salem, Ind.

New York City.

Newark, N.J.

Upper Alton, Ill.

Lincoln, $\mathbf{I l}$.

Tuscola, Ill.

Mansfleld, 0.

Columbus, $\mathrm{O}$.

Millford, Mich.

Black Creek, N. Y.

East Berlin, Conn.

Moundsville, W. Va

Washington, D. C.

Gratiot, 0.

Lansing, Iowa.

London, Ind.

Barnesville, 0.

New York City.

Redding, Conn.

Battle Creek, Mich. 
Name.

Bassett, MI. M.,

Bassett, A. H.,

Ballow, O. G.,

Baird, J. F.,

Baird, Jno.,

Bannister, D. A.,

Barse, G. R.,

Baker, S. S.,

Bader, H.,

Bath, W. L.,

Bascomb, R.,

Barroll, E.,

Bedwell, J. F.,

Bevington, H. S.,

Berry, W. H.,

Beadle, MI.

Bennett, F. T.,

Beegle, D. F.,

Bierbower, W.,

Bisby, L. C.,

Bisby, J. D.,

Biggs, Jas.,

Bickham, T.,

Bischoff, P.,

Birun, E. G.,

Blair, R. F.,

Blair, G. E.,

Blancherd, W.,

Blakeslee, B. F.,

Bleak, G. C.,

Blue, J. G.,

Booher, A. H.,

Boyd, F. W.,

Borchess, T. J.,

Boone, S. G.,

Boughton, S. T.,

Bowers, G. A.,

Brownell, T. I.,

Bromn, J. I.,
Regiment or Command.

53d Ill. Infantry.

70th Ill. Infantry.

100th 0 . Infantry.

1st Va. Infantry,

S9th O. Infantry.

59th O. Infantry.

5th Mich. Cavalry.

6th Mo. Infantry.

29th Mo. Infantry,

$132 d$ N. Y. Infantry.

50th N. Y. Infantry,

11th Tenn. Infantry.

80th 0. Infantry.

123d O. Infantry.

5th Ill. Cavalry.

$123 d \mathrm{~N}$. Y. Infantry,

18th U. S. Infantry.

101st Pa. Infantry,

87th Pa. Infantry,

16th Me. Infantry,

16th Me. Infantry,

123d Ill. Infantry.

19th U. S. Infantry.

6th U. S. Artillery,

3d Mass. Infantry.

123d O. Infantry,

17th O. Infantry.

$2 d$ U. S. Cavalry.

16th Conn. Infantry,

3d Mo. Infantry.

3d O. Infantry,

73d Ind. Infantry,

123d O. Infantry.

67th Pa. Infantry,

8sth Pa. Infantry,

71st $\mathrm{Pa}$. Infantry.

16th Conn. Infantry,

51st Ind. Infantry.

73d Ind. Infantry.
Residence.

Wheeling, W. Va.

Cape Girardeau, Mo.

Rome, N. Y.

South Easton, N. Y.

Rainsburg, $\mathrm{Pa}$.

York, Pa.

Canton Mills, Me.

Canton Mills, Me.

St. Louis, Mo.

Norwalk, O.

New Britain, Conn.

Gardington, $\mathrm{O}$.

Westrille, III.

Dyberry, $\mathrm{Pa}$.

Reading, $\mathrm{Pa}$.

Hartford, Conn. 
Name.

Breckenridge, F. A.,

Brueting, J. G. W., Bradford, R. Y.,

Bradford, Jno.,

Bricker, W. H.,

Brush, J. T.,

Brown, J. P.,

Brown, J. L.,

Brown, W. L.,

Brown, W. H.,

Brown, G. L.,

Bryant, MI. C.,

Brandt, O. B.,

Brandt, C. L.,

Brooks, E. P.,

Bryan, Gny,

Bryan, J. H.,

Bradley, A. B.,

Bruns, H.,

Bryson, R. R.,

Burns, Jas.,

Burns, S. D.,

Button, G. W.,

Burdick, C. A.

Butler, W. O.,

Batler, C. P.,

Baffum, G. W.,

Bush, Geo. M.,

Butts, L. A.,

Byers, S. H.,

Byron, S.,

Caswell, H.,

Cameron, P.,

Caldwell, C.,

Caldwell, D. B.,

Callahan, A. M.,

Carothers, J.,

Calver, T. P.,

Carpenter, S. D.,
Regiment or Command.

123d O. Infantry,

5th Md. Infantry,

$2 \mathrm{~d}$ W. Tenn. Infantry.

A. C. S. U. S. vols.,

3d Pa. Cavalry,

100th O. Infantry.

15th U. S. Infantry,

73d Ind. Infantry.

17th Tenn. Infantry.

93d O. Infantry,

101st $\mathrm{Pa}$. Infantry,

42d Ill. Infantry,

17th $O$. Infantiy,

1st N. Y. Veterans,

6th Wis. Infantry.

18th Pa. Cavalry,

184th Pa. Infantry,

85th N. Y. Veterans,

16th Conn. Infantry,

103d $\mathrm{Pa}$. Infantry,

57th $\mathrm{Pa}$. Infantry,

103d Pa. Infantry,

22d Mich. Infantry,

10th Wis. Infantry.

10th Wis. Infantry.

29th Ind. Infantry,

1st Wis. Infantry.

85th N. Y. Veterans,

5th Ia. Infantry,

2d U. S. Infantry.

95th IIl. Infantry.

16th N. Y. Cavalry.

1st Wis. Cavalry,

75th O. Infantry.

73d Ind. Infantry.

7Sth O. Infantry.

123d 0 . Infantry.

$3 d 0$. Infantry.
Residence.

Monroeville, $\mathrm{O}$.

Baltimore, Md.

Hoboken, N. J.

Newville, $\mathrm{Pa}$.

Dayton, $\mathrm{O}$.

Dayton, $\mathrm{O}$.

Milton, $\mathrm{Pa}$.

Kankakee, IIl.

Lancaster, $\mathbf{O}$.

Belmont, N. Y.

Vincenttown, N. J.

Harrisburg, $\mathrm{Pa}$.

Friendship, N. Y.

Bridgeport, Conn.

Butler, $\mathbf{P a}$.

Clark's Post, Pa.

Circleville, $\mathrm{Pa}$.

Farmington, Mich.

Peru, Ill.

Cuba, N. Y.

Newton, Iowa.

Iind, Wis.

Springfield, $\mathbf{0}$. 
Name.

Carpenter, E. D., Carpenter, J. Q.,

Carman, J. A., Carey, S. E., rary, G. W., Cain, J. H., Carlisle, J. B., Calkins, W. W., Canston, M. C., Carter, J. F., Catlett, C. W., Carlin, C. J., Casdorph, C. H., Celley, G.,

Chandler, J. H., Chandler, G. W., Chandler, G. A., Chase, A. G., Chamberlain, H. B., Childs, J. U., Chatburn J., Clark, H. L., Cloadt, A. Clement, J., Cleghorn, Geo., Clifford, W., Cooper, A., Cooper, A. S., Colwell, J. C., Conn, Jno. H., Connelly, R. J., Conelly, D. J., Colloday, S. R., Cook, J. D., Cook, J. H., Cook, W. B., Cowles, H. F., Coffin, J. A., Coffin, G. A,
Regiment or Command. 1sth Conn. Infantry. 150th $\mathrm{Pa}$. Infantry, 107th $\mathrm{Pa}$. Infantry. 13th Mass. Infantry, 65th Ind. Infantry. 104th N. Y. Infantry, 2d Va. Infantry, 104th Ill. Infantry, 19th U. S. Infantry. 9th Md. Infantry, 2d E. Tenn. Infantry 151st N. Y. Infantry. 8th Va. Cavalry, 4th O. Cavalry. 5th Md. Infantry. 1st Va. Cavalry, 15th Mo. Infantry. 16th Conn. Infantry, 97th N. Y. Infantry. 16th Me. Infantry. 150th $\mathrm{Pa}$. Infantry, 9th Mass. Artillery, 119th N. Y. Infantry, 15th Ky. Cavalry, 21st O. Infantry. 16th U. S. Infantry. 12th N. Y. Cavalry, 9th MI. Infantry. 16th Ill. Cavalry, 1st Va. Cavalry. 73d Ind. Infantry. 63d N. Y. Infantry, 6th $\mathrm{Pa}$. Cavalry. 6th Ia. Infantry, 5th Md. Infantry. 140th $\mathrm{Pa}$. Infantry, 1Sth Conn. Infautry. 157th N. Y. Infantry, 29th Ind. Infantry.
Residence.

Germantown, $\mathbf{P a}$

Boston, Mass.

Albany, N. Y. Ironton, Iowa. Ottaws, III.

Baltimore, Md.

Kanawha, W. Vir.

Birmingham, 0 .

Simsbury, Conn.

Farmington, $\mathrm{Me}$. Germantown, $\mathrm{Pa}$. Springfield, Mass. Washington, D. C. Newalton, Ind.

Oswego, N. Y.

Chicago, Ill.

New York City.

St. Louis, Mo.

Candor, $\mathrm{Fy}$.

Oswego, N. $\mathbf{Y}$. 
Name.

Coles, B.,

Cole, O. L,

Coleman, G. B.,

Coleman, T. S.,

Cox, J. L.,

Cochran, T. G.,

Cohen, M.,

Cottingham, E.,

Christopher, W.,

Crossley, T. J.,

Croker, Hyde,

Crawford, H. B.;

Crawford, W. H.,

Cubbinson, J. C.,

Cubbetson, W. M.,

Curry, W. A.

Custed, J. W.,

Cumis, L. B.,

Curtice, H. A.,

Curtis, Radolph,

Cuniffe, H.,

Davis, V. R.,

Davis, C. G.,

Davis, B.,

Davis, E. J.,

Davis, J. W.,

Davidson, John,

Day, J. R.,

Day, J. W.,

Day, A. P.,

Daily, Jno.,

Daily, W. A.,

Darnin, S. G.,

Dewies, S. B.,

Devine, J. S.,

Deering, Geo. A.,

Dean, Thos. J.,

Dilan, J. A.,

Drenner, Mr.
Regiment or Commana.

2d N. Y. Cavalry,

51st Ill. Infantry,

1st Mass. Cavalry.

12th Ky. Cavalry.

21st III. Infantry.

77th $\mathrm{Pa}$. Infantry,

4th Ky. Cavalry,

35th O. Infantry.

2d Va. Cavalry.

157th $\mathrm{Pa}$. Infantry,

1st N. J. Cavalry,

2d Ill. Cavalry.

2d E. Tenn. Infantry.

101st $\mathrm{Pa}$. Infantry,

30th Ind. Infantry.

3d 0 . Infantry.

23d Ind. Infantry.

17th Mass. Infantry.

157th N. Y. Infantry,

4th Ky. Cavalry,

13th Ill. Infantry.

123d O. Infantry.

1st Mass. Cavalry,

7lst $\mathrm{Pa}$. Infantry.

44th Ill. Infantry,

115th N. Y. Infantry.

6th N. Y. Artillery,

3d Me. Infantry,

17th Mass. Infantry,

15th Conn. Infantry,

104th N. Y. Infantry,

8th $\mathrm{Pa}$. Cavalry,

16th U. S. Infantry.

$2 d$ U. S. Infantry.

71st $\mathrm{Pa}$ Infantry,

16th Me. Infantry.

5th Mich. Infantry,

51st Ind. Infantry.

10th Mo. Infantry.
Residence.

New York City.

Elgin, IIl.

Chambersburg, $\mathbf{P a}$

Louisville, Ky.

Titasville, $\mathbf{P a}$

Port Jervis, N. J.

Irish Ripple, $\mathbf{P a}$

Courtlandt, N. Y.

Lonisville, Ky.

Worcester, Mass.

Rocktown, $\mathrm{nl}$.

Haverstraw, N. $\mathbf{Y}$.

Waterville, Me.

Averill, Mass.

New Haven, Conn.

Troy, N. Y.

Philadelphia, $\mathbf{P a}$.

Philadelphia, $\mathrm{Pa}$.

Wayne, Mich. 


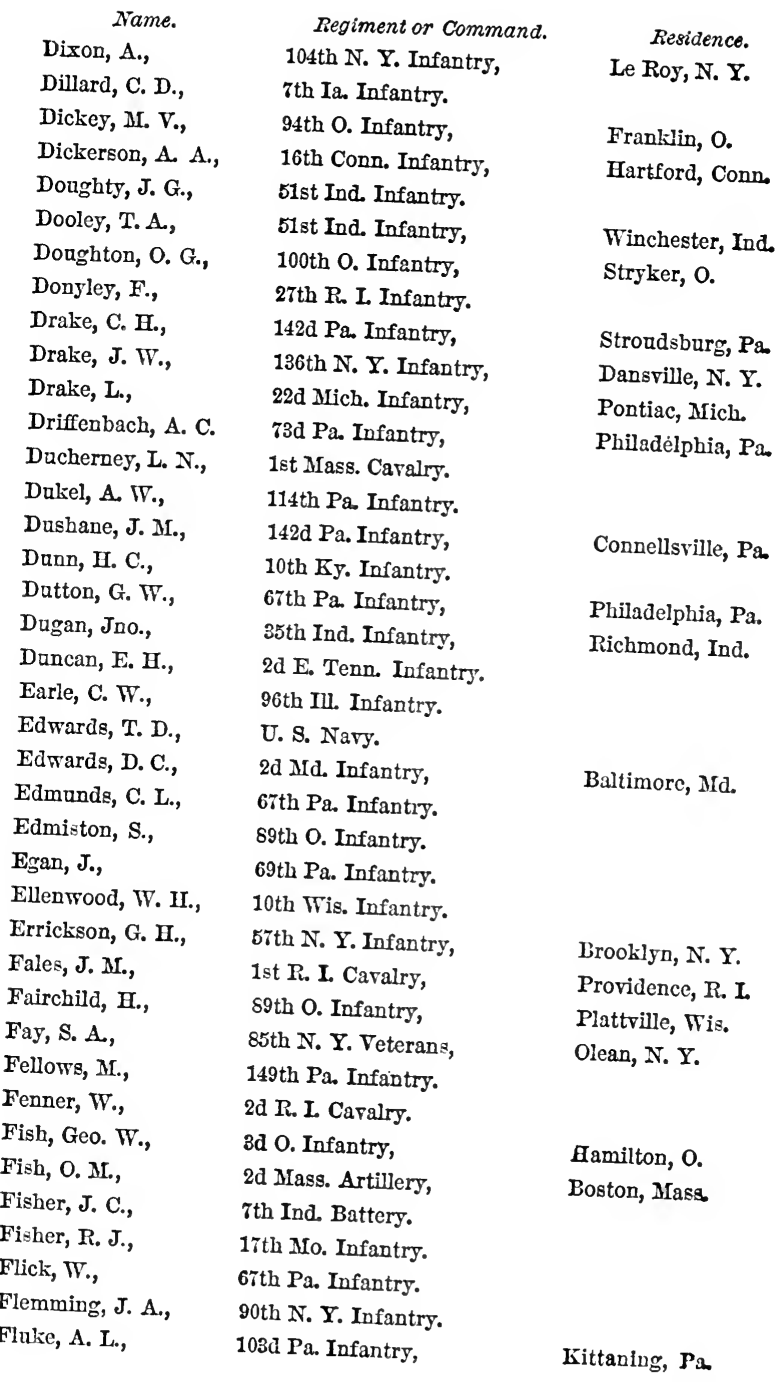


Name.

Fortescue, L. P., Forsyth, + G. D., Fowler, G. H., Foster, E. F., Follette, W. H., Fontaine, J., Fox, D. D., Fox, J. D., Fobes, E. II., Foot, M. C., Francis, J. A, Freeman, T. C., Fritze, Chas., Fritz, J., Fritchie, A. W., Frost, C. W., Fry, A., Gamble, S. P., Gamble, II., Gamble, Geo. H., Garces, Jno. A., Gray, F. C., Garrett, E. L., Garbet, D., Galloway, W. G. Gagerly, J. H., Gates, R. C., Gater, A. L., Geasland, S. A., Gebhardt, H., Gilmore, J. A., Gilleland, F. M., Glazier, W. W., Goodrich, J. O., Goodwin, A., Gorgus, E. G., Gorf, J. MI.,
Regiment or Command. 29th Pa. Infantry. 100th 0. Infantry. 100 th 0 . Infantry. 30th Ind. Infantry. Mass. Artillery, 73d $\mathrm{Pa}$ Infantry, 16th Ill. Cavalry, 16th IIl. Cavalry, 131st N. Y. Infantry. 92d N. Y. Infantry, 1Sth Conn. Infantry. 18th U. S. Infantry. 24th IIl. Infantry, 11th Tenn. Infantry. 26th Mo. Infantry, 85th N. Y. Veterans, 73d Ind. Infantry, 63d $\mathrm{Pa}$. Infantry, 7od Ind. Infantry. 8th Ill. Cavalry. 1st Ma. Cavalry. 11th $\mathrm{Pa}$. Infantry, 4th Mo. Cavalry. 77th Pa. Infantry, 15th U. S. Infantry. 19th U. S. Infantry. 18th U. S. Infantry. 10th Wis. Infantry, 11th Tenn. Cavalry, 24th IIl. Infantry. 79th N. Y. Infantry. 15th Ky. Infantry. 2d N. Y. Cavalry, 85th N. Y. Veterans, 82d O. Infantry. 90th $\mathrm{Pa}$. Infantry. 10th Wis. Infantry.
Residence.

Quincy, Hass.

Washington, D. C.

Aurora, Ill.

Aurora, IIl.

Cooperstown, N. Y.

Chicago, Ill.

St. Louis, Mo.

Rochester, N. Y.

Crown Point, Ind.

Pittsburgh, $\mathrm{Pa}$.

Donegal, Pa.

Hyde Park, Pa.

Eeustiford, Wis. Kingston, Tenn.

Fowler, N. Y.

Scottsville, N. Y. 


\begin{tabular}{|c|c|c|}
\hline Name. & Regiment or Command. & Residenco. \\
\hline Gore, J. B., & 15th Ill. Infantry. & \\
\hline Gordon, E., & 81st Ind. Infantry. & \\
\hline Good, Geo., & 84th $\mathrm{Pa}$. Infantry. & \\
\hline Grant, G. W., & 8Sth Pa. Infantry, & Reading, $\mathrm{P}_{\mathrm{a}}$ \\
\hline Gray, R. H., & 15th U. S. Infantry, & Cleveland, 0. \\
\hline Gray, M., & 13th N. Y. Infantry, & Naugatuck, Conn. \\
\hline Green, M. E., & 5th Md. Cavalry. & \\
\hline Green, J. A., & 13th $\mathrm{Pa}$. Cavalry. & \\
\hline Green, C. W., & 44th Ind. Infantry. & \\
\hline Greble, C. E., & 8th Mich. Caralry, & Battlo Creek, Mich. \\
\hline Grierson,† O., & 45th N. Y. Infantry. & \\
\hline Griffin, W. G., & 112th Ill. Infantry, & Cambridge, Ill. \\
\hline Gross, T., & 21st Ill. Infantry, & Belment, Ill. \\
\hline Grade, A., & 51st Ind. Infantry, & Russelville, Ind. \\
\hline Gutland, C. F., & 134th N. Y. Infantry. & \\
\hline Harmer, R. J., & soth Ill. Infantry. & \\
\hline Harvey, W. H., & 51st Ind. Infantry. & \\
\hline Hand, G. D., & 51st Ind. Infantry, & Shelbyrille, Ind. \\
\hline Harns, D. H., & 3d O. Infantry. & \\
\hline Haideman, Jno., & 129th IIl. Infantry. & \\
\hline Hawkins, W., & 5th Md. Infantry. & \\
\hline Hawkins, S. W., & 7th Tenn. Cavalry, & Huntingdon, Tenn. \\
\hline Hakes, D. W., & 18th Conn. Infantry. & \\
\hline Hall, C. B., & 1st Va. Cavalry. & \\
\hline Hall, J., & 87th $\mathrm{Pa}$. Infantry. & \\
\hline Hall, C. T., & 13th Mich. Infantry, & Battle Creek, Mich. \\
\hline Hallenburg, J. G., & 1st 0. Infantry, & Lonisville, Ky. \\
\hline Hagenbach, J. C., & 67th $\mathrm{Pa}$. Infantry, & Philadelphia, $\mathrm{Pa}$ \\
\hline Hauf, A, & 5th N. Y. Infantry. & \\
\hline Halpin, G., & 116th $\mathrm{Pa}$. Infantry, & Philadelphia, Pa. \\
\hline Harkness, E. H., & 6th $\mathrm{Pa}$. Cavalry. & \\
\hline Hatfield, J. D., & 53d Ill. Infantry. & \\
\hline Hayes, A. W., & 34th 0 . Infantry. & \\
\hline Hammond, J. F., & $\longrightarrow$ & \\
\hline Hatcher, W. S., & 30th 0 . Infantry. & \\
\hline Hanon, J., & 115th Ill. Infantry. & \\
\hline Harrison, C. E., & 89th 0. Infantry, & Higginsport, $\mathrm{O}$. \\
\hline
\end{tabular}


Nams.

Harris, Geo.,

Harris, S.,

Hamilton, W. B.,

Hamilton, W.,

Hale, G. W.,

Harboar, E.,

Harrington, B. F.,

Hays, Jno. W.,

Hart, C. MI,

Hastings, T. J.,

Hastings, G. L.,

Hampton, C. G.,

Hagen, P. A.,

Heffner, W.,

Hersh, J.,

Heflley, C. P.,

Henry, J. M.,

Henry, C. D.,

Helms, M. B.,

Helm, J. B.,

Henkley, L. D.,

Heslit, Jas.,

Heppard, T. H.,

Herrick, L. C.,

Higginson, T. J.,

Higgins, J. D.,

Hinds, H. H.,

Hine, Jno. J.,

Higly, E. H.,

Hicks, D. W.,

Hill, J. B.,

Holmes, J. B.,

Hood, Jno.,

Horton, S. H.,

Hodge, W. E.,

Hodge, W. P.,

Horney, P.,

Holden, Ell,

Howe, B.,
Regiment or Command.

79th Ind. Infantry.

5th Mich. Cavalry,

22d Mich. Infantry,

2d Mass. Artillery,

101st O. Infantry,

2d E. Tenn. Infantry.

18th Pa. Cavalry,

5th Ia Infantry.

45th $\mathrm{Pa}$ Infantry.

15th Mass. Infantry,

24th N. Y. Battery,

15th N. Y. Cavalry,

Tth MId. Infantry.

67th $\mathrm{Pa}$. Infantry,

87th $\mathrm{Pa}$. Infantry.

142d Pa. Infantry,

154th N. Y. Infantry,

4th O. Cavalry,

1st Va. Cavalry,

101st $\mathrm{Pa}$. Infantry,

10th Wis. Infantry,

3d Pa. Cavalry,

101st $\mathrm{Pa}$. Infantry,

1st N. Y. Cavalry,

18th Conn. Infantry.

67th $\mathrm{Pa}$. Infantry,

100th O. Infantry.

1st Vt. Cavalry,

9th O. Cavalry.

17th Mass. Infantry,

6th O. Infantry.

80th IIl. Infantry.

101st $\mathrm{Pa}$. Infantry.

5th Md. Infantry,

2d E. Tenn. Infantry.

110th O. Infantry.

1st Vt. Cavalry,

21st IIl. Infantry.
Restience.

Romeo, Mich.

West Amesbury, Mass.

Upper Sandusky, 0.

Waynesburg, $\mathrm{Pa}$.

Worcester, Mass.

Oswego, N. Y.

Brockport, N. Y.

Pottsville. $\mathbf{P a}$.

Berlin, $\mathbf{P a}$

Olean, N. Y.

Tiffin City, 0.

Rosby's Rock, W. Va.

Shellsbarg, $\mathbf{P a}$.

Wanfran, Wis.

Baltimore, Md.

Philadelphia, $\mathrm{Pa}$.

Syracuse, N. $\mathbf{Y}$.

Montrose, $\mathrm{Pa}$.

Castleton, Vt.

Averill, Mass.

Baltimore, MId.

Barre, $\nabla t$. 
Name.

Houlchen, P. W.,

Holbruck, S. S.,

Horway, H.,

Hoffman, Jno.,

Houston, G. C.,

Holloway, J. M.,

Hoppin, H. P.,

Holman, W. C.,

Hubbell, F. A.,

Huggins, Thos.,

Hubbard, H.,

Hubbard, H. R.,

Hudson, W. M.,

Hutchinson, J. R.,

Huey, R.,

Hunter, A. W.,

Huntley, C. C.,

Irwin, C. L.,

Irwin, W. H.,

James, H. H.,

Jackson, R. W.,

Jackson, T. W.,

Jenkins, J. H.,

Johnson, G.,

Jones, J. P.,

Jones, C. W.,

Jones, P. O.,

Jones, J. A.,

Jones, H.,

Jones, R. B.,

Jordon, H. P.,

Kane, Jas.,

Kautz, J. D.,

Kepp, Eug.,

Kephart, J. S.,

Kerin, Jas.,

Keruger, Wm.,

Keyes, G.,

Kendler, H.,
Regiment or Command.

16th U. S. Infantry.

15th U. S. Infantry.

78th Ill. Infantry.

5th Ia. Infantry.

2d N. Y. Cavalry,

6th Ind. Infantry.

2d Mass. Artillery,

9th Vt. Infantry,

- Pa. Infantry,

2d N. J. Cavalry.

12th N. Y. Infantry.

119th IIl. Infantry.

92d O. Infantry.

2d Va. Cavalry,

$2 d \mathrm{E}$. Tenn. Infantry.

2d U. S. Artillery,

16th Iil. Cavalry,

7Sth IIl. Infantry.

103d $\mathrm{Pa}$. Infantry,

6th Ind. Cavalry,

21st Wis. Infantry,

10th N. Y. Cavalry,

21st Wis. Infantry,

16th Conn. Infantry,

55th 0 . Infantry,

16th Pa. Cavalry,

2d N. Y. Cavalry,

21st Ill. Infantry,

5th U. S. Cavalry,

$2 \mathrm{~d}$ E. Tenn. Infantry.

9th Me. Infantry.

13th Pa. Cavalry.

1st Ky. Cavalry,

82d Ill. Infantry.

5th Mrd. Cavalry,

6th U. S. Cavalry,

2d Mo. Infantry,

18th Conn. Infantry.

45th N. Y. Infantry.
Residence.

Concord, N. H.

Cambridge, Mass.

West Braintree, Vt.

IIonesdale, $\mathbf{P a}$.

Pittsburgh, $\mathrm{Pa}$.

New Hadson, Mich.

Huntly, Ill.

Allegheny City, Pa.

Montezuma, Ind.

Oskosh, Wis.

Wolcott, N. Y.

Oskosh, Wis.

Hartford, Conn.

Norwalk, 0.

Duncannon, $\mathbf{P a}$.

Brooklyn, N. Y.

Olney, Ill.

Washington, D. C,

Dent, 0.

Franklin, Ind.

Washington, D. C.

St. Louis, Mo. 
Name.

Kennedy, J. W.,

Kellog, J. C.,

Kelly, D. O.,

Kelly, H. B.,

Kenniston, J.,

Keith, C. E.,

Kendall, Theo.,

Keister, W. H. II.,

King, John,

King, M. D.,

King, J. B.,

King, T.,

Kibbe, J. N.,

Kimball, T. D.,

Kittrel, D. F.,

Kirby, W. MI.,

Kirk, J. B.,

Kirkpatrick, G. W.

Knight, H. V.,

Knaggs, R. C.,

Knowles, R. A.,

Knowles, E. M.,

Knapp, F. H.,

Knoble, E. E.,

Koach, S.,

Kresge, A.,

Krocks, T. A.,

Kupp, M.,

Kuhn, A. J.,

Kunkel, J.,

Lapton, L.,

Laws, W. L.,

Lamson, A. T.

Lenning, T.,

Leyton, F. A.

Leith, Sam.,

Leydecker, J.,

Leslie, J. In,

Leonard, A.,
Regiment or Command.

Residence.

134th N. Y. Infantry.

6th Mich. Infantry.

100th O. Infantry,

6th Ky. Cavalry.

100th III. Infantry,

19th Ill. Infantry,

15th U. S. Infantry,

103d $\mathrm{Pa}$. Infantry,

5th Ill. Cavalry,

3d O. Infantry,

10th N. Y. Cavalry.

101st Pa. Infantry,

1Sth Conn. Infantry.

8sth Ind. Infantry.

3d E. Tenn. Infantry.

$3 d$ N. Y. Artillery,

101st Pa. Infantry,

15th Ia. Infantry,

20th Mich. Infantry,

A. D. C., U. S. Vols.,

116th O. Infantry.

$42 \mathrm{~d}$ Ind. Infantry.

9th O. Cavalry.

21st Ky. Infantry.

100th IIl. Infantry.

67th $\mathrm{Pa}$. Infantry.

7th $\mathrm{Pa}$ Infantry.

167th $\mathrm{Pa}$. Infantry.

5th Md. Infantry.

45th N. Y. Infantry.

116th O. Infantry.

18th $\mathrm{Pa}$. Infantry.

104th N. Y. Infantry,

6th Pa. Cavalry,

18th Ind. Infantry.

132d N. Y. Infantry.

45th N. Y. Infantry.

18th Pa. Cavalry,

71st N. Y. Infantry.
Kelly's Island, O.

Joliet, IIl.

Chicago, Ill.

Brooklyn, N. Y.

Hillsville, $\mathbf{P a}$

Genera, IIl.

Barnesville, 0.

Bradford, Pa.

Hillsville, $\mathrm{Pa}$

Smyrna, Iowa.

Battle Creek, Mich.

Ann Arbor, Mich.

Philadelphia, Pa.

Genesee, N. Y.

Philadelphia, $\mathbf{P a}$.

Titusville, $\mathbf{P a}$. 
Name.

Lindsay, A. H., Lindemyer, I., civingston, C. H., Lintz, M. J., Lloyd, T. S. C., Loomis, A. W., wocke, W. H., Locke, D. R., Locklin, A. W., Lombard, H. G., Lodge, G. R., Longnecker, J. II., Lndlow, J., Lyon, W. S., Madera, W. B., Markbrut, L., Marshall, W. S., Manning, J. S., Mann, B. N., Maver, Thos., Mahon, Mr., Mahony, J. S., Mackey, J. T., Mathews, A. S., Mason, J. H., Maw, G., Maxwell, C. A, McAdams, Jno., McBeth, J., McCall, 0 , McCafferty, N. J., McClure, T. W., McConnelee, W. J., IricColgen, J., McCumas, Jno., McCully, D., McDill, W. H., McDonald, J., McDade, A.,
Regiment or Command.

18th Conn. Infantry, 45th N. Y. Infantry, 1st $\mathrm{Va}$. Cavalry, 8th Tenn. Infantry. 6th Ind. Cavalry, 18th Conn. Infantry, 18th Conn. Infantry, 8th Ky. Cavalry. 94th N. Y. Infantry, 4th Mich. Infantry, 53d III. Infantry, 101st $\mathrm{Pa}$. Infantry, 5th U. S. Artillery. 23d O. Infantry, 6th W. Va. Infantry, A. D. C. U. S. Vols. 51st Ind. Infantry. 100th O. Infantry. 17th Mass. Infantry. 100th 0 . Infantry. 16 th U. S. Infantry. 15th U.S. Infantry, 16th U. S. Infantry, 22d Mich. Infantry, 21st 0 . Infantry. soth O. Infantry. 3d O. Infantry, 10 th $\nabla \mathrm{a}$. Infantry. 45th 0 . Infantry, 103d $\mathrm{Pa}$ Infantry, 4th U. S. Artillery, 6th U. S. Artillery, 4th Ia. Infantry, 7th O. Cavalry, 5th Md. Infantry. 75th 0 . Infantry. 80th Ill. Infantry. 2d E. Tenn. Infantry. 154th N. Y. Infantry,
Residence.

Greenville, Conn.

New York City.

Uniontown, $\mathrm{Pa}$.

Terre Haute, Ind.

Tolland, Conn.

Willimantic, Conn.

Great Bend, N. Y.

Chicago, Ill.

Ottawa, III.

Woodbury, $\mathrm{Pa}$.

Leeville, 0.

Morganstown, Va

Prairie Depot, 0.

Dallas City, III.

Pontiac, Mich.

Springfleld, 0.

Zanesville, 0. Rimersburg, $\mathrm{P}_{\text {a }}$ Pittsburgh, $\mathrm{Pa}$ Wabash, Ind. Wintersett, Iowa. Georgetown, 0.

Westfleld, N. Y. 
Name.

SIcElroy, Wm.

Mccinnis, T. F.,

McGowan, J.,

AlcGovern, J.,

McHenry, C.,

McKinstry, J.,

McKinley, J.,

McKeag, F.,

MicKee, T. H., McKee, N. S., MrcKay, D. F., McKay, R. G., McKinson, A. H., McLane, A. U., MrNeal, S., McNiece, A, Merritt, H. A. D., Merry, W. H., Mettee, J. S., Meil, J. R., Messick, J. W., Mead, L. C., Mead, W. H., Mendenhall, J. A., Ileyer, H. F., Merwin, S. F. C., siller, C., Miller, W. G., Milward, T., Missehl, O., Millis, Jno., Mitchell, J. A., Mitchell, J., Moore, W. R., Moore, M. M., Moore, D. T., Moore, F., Mooney, J., Moon, R. A.
Regiment or Command.

3d IIl. Infantry.

1Sth Conn. Infantry.

29th Ind. Infantry.

73d $\mathrm{Pa}$. Infantry.

85th N. Y. Veterans,

16th Ill. Cavalry,

2sth O. Infantry.

18th Conn. Infantry,

21st IIl. Infantry.

21st Ill. Infantry.

1Sth Pa. Infantry,

1st Mich. Infantry,

10th Wis. Infantry,

2d O. Infantry.

51st O. Infantry,

73d $\mathrm{Pa}$. Infantry.

5th N. Y. Cavalry,

106th N. Y. Infantry,

5th MI. Infantry.

s2d III. Infantry,

42d Ind. Infantry,

22d Mich. Infantry.

6th Ky. Cavalry.

75th O. Infantry, .

9th Ind. Infantry.

18th Conn. Infantry,

14th 1ll. Cavalry,

16th Conn. Infantry.

31st O. Infantry.

68th N. Y. Infantry.

66th Ind. Infantry,

$82 d 0$. Infantry.

79th IIl. Infantry.

2d Ma. Cavalry,

6th Mich. Cavalry.

2d E. Tenn. Infantry,

$73 \mathrm{~d} \mathrm{~Pa}$. Infantry.

107th $\mathrm{Pa}$. Infantry,

6th Mich. Cavalry,
Residence.

East Bloomfield, N. Y,

Matoon, Ill.

Norwich, Conn.

Meadeville, $\mathbf{P a}$.

Beloit, Mich.

Pine Hill, Wis.

Spring Mountain, O.

Hoboken, N. J.

Ogdensburg, N. Y.

Deerfield, 0.

Evansville, Ind.

Ringgold, $\mathrm{O}$.

Norwich, Conn.

Chicago, Ill.

Paoli, Ind.,

Wilmington, Del.

Clinton, Tenn.

Dushane, $\mathrm{Pa}$.

Big Rapids, Mich. 
Rame.

Morris, J. M., Morris, W. J., Morris, A.,

Morrison, M. V. B., Morisey, G. H., Morse, C. W., Morse, A., Alorse, G. IV., Morgan, J. T., Morgan, C. H., Silorey, H., Moran, F., Montgomery, R. H., Mosby, Thos., Mosely, H. H., Mosher, H. E., Morningstar, H., Miunday, J. D., Murdock, J. II., Murdock, II. S., Jurray, C., Murray, A. II, Murphy, F., Myers, Thos., Miflieus, V., Nelson, Wm., Newbrandt, J. F., Neimeger, B. H., Norris, A. N., Norris, O.R., Nowlan, W. J., Noreross, J. C., Nyce, Wm., Oats, J. G, O'Connor, Jas., O'Connor, W., Ong, O. C., Parcey, E. WT., Parker, E. B.,
Regiment or Command. 101st $\mathrm{Pa}$. Infantry. 5th Md. Infantry, 4th Ky. Cavalry. 32d O. Infantry, 12th Ia. Infantry. 16th Conn. Infantry, 7Sth III. Infantry, 9th Md. Infantry, 17th Mich. Infantry, 21st Wis. Infantry. 10th N. Y. Cavalry. $73 d$ N. Y. Infantry, 5th U. S. Cavalry. 12th $\mathrm{Pa}$. Cavalry. 25th O. Infantry, 12th N. Y. Cavalry. 87th Pa. Infantry, 73d Ind. Infantry, 3d O. Infantry. 73d Ind. Infantry, 15th Mo. Cavalry, U. S. Artillery. 97th N. Y. Infantry, 107th $\mathrm{Pa}$. Infantry, 6sth N. Y. Infantry. 13th U. S. Infantry. 4th Mo. Cavalry, 11th Ky. Cavalry. 107th $\mathrm{Pa}$. Infantry. 11th O. Infantry. 14th N. Y. Infantry. $2 d$ Mass. Cavalry, 2d N. Y. Caralry, 3d O. Infantry, 59th 0 . Infantry. 13th $\mathrm{Pa}$. Cavalry, 2d Va. Caralry, s0th Ill. Infantry. Ist Vt. Artillery,
Restdence.

Baltimore, Md.

Chilicothe, O.

New Hartford, Conn Alacomb, Il. Lovington, Tenn. Ypsilanti, Mich.

New York City.

Summerfield, O.

Hanover, $\mathrm{Pa}$.

La Porte, Ind.

Logansport, Ind.

St. Louis, Mo.

Salisbary Centre, N. Y Chambersbarg, $\mathrm{Pa}$.

Cincinnati, $\mathrm{O}$.

Farmington, Me.

Hainesville, N. J.

Greenwich, $\mathrm{O}$.

Philadelphia, $\mathrm{Pa}$ Meigsville, $\mathrm{O}$.

Providence, R. I. 
Name.

Parker, E. C.,

Paulding, T.,

Paul, J. S.,

Palmer, E. L.,

Patterson, J. B.,

Paxton, M. N.,

Patelin, A. E.,

Peake, L. S.,

Pelton, E. A.,

Peterson, C. G. A.,

Pettijohn, D. B.,

Pentzel, G.,

Perley, Jas. P.,

Perlin, H.,

Pettrie, L. B.,

Petts, G. W.,

Phares, W.,

Phillips, F.,

Phelps, L. D.,

Pierson, E. C.,

Piper, S. B.,

Pierce, Wm. B.,

Platt, Henry S.,

Potter, G. A.,

Potter, H. C.,

Potter, E. D.,

Potts, G. H.,

Potts, C. P.,

Poole, J. F.,

Powers, J. L.,

Powell, C.,

Pond, R. H.,

Prather, Z. R.,

Prutzman, C. Mr.,

Pumphrey, J. B.,

Purnell, W. G.,

Pulliam, M. B.,

Randall, Wm.,

Randolph, W. F.,
Regiment or Command.

Residence.

94th N. Y. Infantry.

6th U. S. Artillery.

122d O. Infantry.

57th N. Y. Infantry,

21st O. Cavalry.

140th $\mathrm{Pa}$. Infantry,

10th Wis. Infantry.

85th N. Y. Veterans,

2d Md. Cavalry,

1st R. I. Cavalry,

2d U. S. Infantry,

11 th N. Y. Infantry.

13th Mich. Infantry,

$2 \mathrm{~d}$ O. Infantry.

126th O. Infantry.

85th N. Y. Veterans,

46 th W. Va. Infantry,

5th Pa. Caralry,

8th $\mathrm{Pa}$. Cavalry,

85th N. Y. Veterans,

3d O. Infantry,

11th Ky. Cavalry.

11th Mich. Infantry.

$2 \mathrm{~d} \mathrm{Ky}$. Infantry,

18th Pa. Cavalry,

6th Mich. Infantry,

75th O. Infantry.

151st $\mathrm{Pa}$. Infantry,

1st Va. Cavalry,

107th N. Y. Infantry,

42d 0 . Infantry.

12th U. S. Infantry.

116th IIl. Infantry.

th Wis. Infantry,

123d O. Infantry,

6th Md. Infantry.

11th Ky. Cavalry.

80th Infantry.

5th U. S. Artillery.
Montville, Conn.

Cannonsburg, $\mathrm{Pa}$.

Hindsdale, N. Y.

Cumberland, Mrd.

Providence, R. I.

Fort Suelling, Minn.

New York City.

Short Tract, N. Y.

Seneca, W. Va.

Philadelphia, $\mathrm{Pa}$.

Colchester, Conn.

Waterloo, N. Y.

Barnesville, 0 .

Cincinnati, $\mathrm{O}$.

Philadelphia, $\mathrm{Pa}$.

Jeddo, Me.

Pottsville, $\mathrm{Pa}$

Martinsburg, W. VE

Gamilton, N. Y.

Plainfield, Wis.

Marseilles, 0. 
Name.

Ray, T. J.,

Rader, J. M.,

Reynolds, Wm.,

Reynolds, E,

Reynolds, S. H.,

Reed, E.,

Remie, J.,

Rennic, D. P.,

Retillery, W. L.,

Reid, J. A.,

Richardson, J. A.,

Richardson, H.,

Ritchie, Jno.,

Ring, Geo.,

Risedon, I.,

Roney, J. C.,

Road, Thos. G.,

Roach, A. C.,

Rothrock, J. M.,

Rockwell, J. P.,

Rockwell, J. O.,

Rockwell, W. E.,

Robinson, J. F.,

Robinson, G. F.,

Robinson, J. L.,

Robbins, N. A.,

Robertson, G. W.

Roberts, G.,

Ross, G.,

Roger, J. R.,

Ruff, J.,

Russell, J. H.,

Rulon, H. E.,

Ruffs, E. W.,

Ryan, John,

Samson, J. B.,

Scudder, A. A.,

Scoville, H. C.,

Scuttermore, G.,
Regiment or Command.

Residence.

49th O. Infantry.

8th Tenn. Infantry.

73d Ind. Infantry.

73d Ind. Infantry.

42d O. Infantry.

3d O. Infantry.

11th Mass. Infantry.

93d O. Infantry.

51st 0. Infantry,

$2 \mathrm{~d}$ N. C. Infantry,

2d N. Y. Cavalry,

19th Ind. Infantry.

sd O. Infantry.

100th O. Infantry.

11th Tenn. Cavalry,

3d O. Infantry,

1st Md. Cavalry.

51st Ind. Infantry,

5th IId. Infantry.

18th Conn. Infantry.

97th N. Y. Infantry,

13th N. Y. Infantry,

67th $\mathrm{Pa}$. Infantry,

80th O. Infantry.

7th Tenn. Cavalry,

4th Me. Infantry,

22d Mich. Infantry,

7th N. H. Infantry,

7th Vt. Infantry,

157th $\mathrm{Pa}$. Infantry,

67th $\mathrm{Pa}$. Infantry,

12th Mass. Infantry,

114th $\mathrm{Pa}$. Infantry.

1st E. Tenn. Infantry.

69th $\mathrm{Pa}$. Infantry.

12th Mass. Infantry,

35th $\mathrm{Pa}$. Infantry.

92d Ill. Infantry,

soth Ill. Infantry.
Roscoe, $\mathrm{O}$.

Whitestown, $\mathbf{P a}$.

Stoncham, Mass.

Huntsville, Tenn.

Newark, 0.

Indianapolis, Ind.

Booneville, N. Y.

Esperance, N. Y.

Scott, $\mathrm{Pa}$.

Huntingdon, $\mathrm{Pa}$.

Union, Me.

Mount Cheneus, Mich.

Dover, N. H.

Vergennes, Vt.

Lancaster, $\mathrm{Pa}$.

Philadelphia, $\mathrm{Pa}$.

Boston, Mass.

W. Bridgewater, Mass.

Rockford, IIl. 
Name.

Schuyler, J. F.,

Schroeder, E. L.,

Schoeder, H.,

Scranton, A. G.,

Schuele, Geo.,

Schrouders, E.,

Schweinfurth, F.,

Scott, R. F.,

Scott, E. S.,

Segaros, Th.,

Seelcy, H. B.,

Sears, D. C.,

Sharp, G. A.,

Sharp, E. E.,

Shepherd, D. J.,

Shepard, E.,

Shaeffer, A. C.,

Shaw, J. C.,

Sinclair, R. B.,

Silver, H.,

Simpson, G. W.,

Simpson, J. D.,

Sibley, H. L.,

Smith, L. S.,

Smith, MI. II.,

Smith, J.,

Smith, C. B.,

Smith, H. C.,

Small, M. R.,

Smythe, W. H.,

Socks, John,

Sowro, C. H.,

Sollers, G. L.,

Songer, A. W.,

Spence, D. M.,

Spencer, F.,

Spaulding, E. J.,

Spalding, E. G.,

spafford," A. C.,
Regiment or Command.

123d O. Infantry,

5th Ifd. Infantry,

$82 d$ Ill. Infantry.

18th Conn. Infantry.

45th N. Y. Infantry.

74th $\mathrm{Pa}$ Infantry.

24th Ill. Infantry,

11th Ky. Cavalry,

89th 0 . Infantry.

80th Ill. Infantry,

86th N. Y. Infantry,

96th N. Y. Infantry.

19th $\mathrm{Pa}$. Cavalry,

51st Ind. Infantry,

5th Ky. Cavalry.

6th O. Cavalry,

2d N. Y. Cavalry,

7th 0. Cavalry.

2d Mass. H. Artillery,

16th IIl. Caralry,

67th $\mathrm{Pa}$ Infantry,

10th Ind. Infantry.

116th 0 . Infantry,

14th N. Y. Infantry,

123d O. Infantry,

76th Pa. Infantry,

4th N. Y. Cavalry,

2d Del. Infantry.

6th MId. Infantry.

16th U. S. Infantry.

5th Md. Infantry.

123d O. Infantry.

9th MId Infantry.

21st Ill. Infantry,

113th Pa. Infantry,

17th O. Infantry,

2d U. S. Cavalry,

22d Mich. Infantry,

21st O. Infantry.
Residence.

Attica, 0.

York, Pa.

Chicago, Ill.

Kirksville, Ky.

Chester, Ill.

S. Troupsburg, N. Y

Philadelphia, $\mathrm{Pa}$.

Hokomo, Ind.

Newburg, 0.

Newton, N. J.

Worcester, Mass.

St. Louis, Mo.

Mauch Chunck, $\mathrm{Pa}$.

Racine, $\boldsymbol{O}$.

Littleton, N. H.

Monroeville, $\mathrm{O}$.

Latrobe, $\mathrm{Pa}$.

New York City.
Xenia, 0.

Pittsburgh, Pa.

Wilmington, $\mathrm{O}$.

Galesburgh, Mich.

Port Huron, Jich. 
Name.

Spindler, "Jno., Sprague, A. W.,

Strong, E. E., Strong, T. B.,

Stoke, G. W.,

Sterenson, D. B., Stevens," W. S., Sterens, G. C., Stewart, T. H., Stewart, Wm., Stuart, D. M. V., Stark, A. M., Stearns, S., Steele, J. M., Sterling, Jno., Stone, L. L., Stole, A., Stroman, C. P., Sullivan, Jno., Sutherland, G. W., Sweadner, Jno., Synder, G. L., Taylor, H. C., Taylor, A. A., Taylor, H., Temple, H., Terwilliger, J. E., Teter, A J., Thomas, A. V., Thomas, G. W., Thompson, R., Thompson, L., Thayer, H. O., Thorn, R. F., Tillotson, H. H., Titus, J. R., Tiffany, M., Timones, E. M. B., Tower, M.,
Regiment or Command.

73d Ill. Infantry.

2.1th Mich. Infantry.

16th Conn.,

11th Ky. Cavalry,

103d Pa. Infantry,

$3 d 0$. Infantry.

101th N. Y. Infantry.

154th N. Y. Infantry,

5th MId. Infantry,

16th U. S. Infantry.

10th Mo. Infantry.

110th O. Infantry.

4th Me. Infantry.

1st W. Va. Infantry,

ed Ind. Infantry.

A. Q. M. U. S. Fols., 6th U. S. Infantry.

87th $\mathrm{Pa}$. Infantry,

ith R. I. Infantry.

126th O. Infantry,

5th Md. Infantry,

104th N. Y. Infantry.

21st Wis. Infantry.

122d O. Infantry,

65th Ind. Infantry.

2d N. Y. Caralry,

85 th N. Y. Infantry,

2d O. Infantry,

73d Ind. Infantry.

10th Wis. Infantry.

67th $\mathrm{Pa}$. Infantry,

$2 d$ U. S. Cavalry.

67th $\mathrm{Pa}$. Infantry.

5th Ey. Cavalry,

73d Ind. Infantry,

3d U. S. Caralry.

1Sth Conn. Infantry.

15th U. S. Infantry.

13th Mass. Infantry.
Residence.

N. Manchester, Conn.

Louisville, Ky.

Orrville, $\mathrm{Pa}$.

Machias, N. Y.

Philadelphia, $\mathrm{Pa}$.

Wellsville, 0 .

Mount Indns Falls, Vte

York, $\mathrm{Pa}$

Smithfield, O.

Liberty, IId.

Cambridge, $\mathrm{O}$.

Brooklyn, N. Y.

Almond, N. $\mathrm{Y}$.

Steubenville, $\mathrm{O}$.

Stoddsville, $\mathbf{P a}$.

Gardner, Kan.

Calumet, Ind. 
Name.

Trommel, Chas.,

Tresouthick, S. H., True, W. M.,

Turmer D.,

Tuthill, E. A.,

Turner, J.,

Tyler Ira,

Tyler, R.

Ulem, A. J. W.,

Undutch, M.,

Uptigrove, J. R.,

Vanness, G. A.,

Vannetter, R. N.,

Vansbury, D.,

Vettford, Geo.,

Vinay, F.,

Warwick, Jno. F.,

Wallace, J. J.,

Wallace, R. P.,

Wallber, A,

Wadsworth, M. C.,

Watson, W. L.,

Wasson, J. Ar.,

Welch, J. C.,

Welsh, W. H.,

Weiser, L.,

Weeks, E. J.,

Weakley, T. J.,

Weatherbee, J.,

Weaver, J. R.,

Weston, C. F.,

Wells, Jas.,

Whiting, J. D.,

White, P. A.,

White, A. H.,

White, A. B.,

Wheeler, W. F.,

Whitney, J. N.,

Whiston, D.,
Regiment or Command.

Residence.

3d O. Infantry.

1sth Pa. Cavalry.

16th Ill. Cavalry,

11Sth Ill. Infantry,

104th N. Y. Infantry,

A. Q. MI. U. S. Vols.

118th Ill. Infantry.

6th Mrd. Infantry.

3d O. Infantry,

9th Md. Infantry.

73d Ind. Infantry.

73d Ind. Infantry,

1st Mich. Cavalry.

4th MId. Battalion.

51th N. Y. Infantry,

85th N. Y. Infantry,

101st Pa. Infantry,

ith Tenn. Cavalry,

120th O. Infantry,

26th Wis. Infantry.

16th Me. Infantry,

21st Wis. Infantry,

40th 0 . Infantry.

85th N. Y. Infantry,

78th $\mathrm{Pa}$. Infantry,

1st Md. Cavalry.

67th Pa. Infantry,

110th 0. Infantry,

51st O. Infantry,

18th $\mathrm{Pa}$. Infantry,

21st Wis. Infantry.

8th Mich. Cavalry.

3d O. Infantry,

83d $\mathrm{Pa}$. Infantry.

27th $\mathrm{Pa}$. Infantry.

4th Pa. Cavalry,

9th MId. Infantry.

2 d R. I. Cavalry,

12th Mass. Infantry.

Latrobe, $\mathrm{Pa}$.
Chicago, Ill.

Warsaw, Ill.

Nnnda, N. Y.

Wreoster, 0 .

Logansport, Ind̋.

New York City.

New York City.

Beaver, $\mathrm{Pa}$.

Dowagiac, Mrich.

Loudonville, 0 .

Pittston, Me.

Waupaca, Wis.

Angelica, N. Y.

York, $\mathrm{Pa}$.

Phœnixville, $\mathrm{Pa}$.

New Carlisle, 0.

Port Washington, 0 .

New York City.

Allegheny City, $\mathrm{Pa}$.

Raymond, Me. 


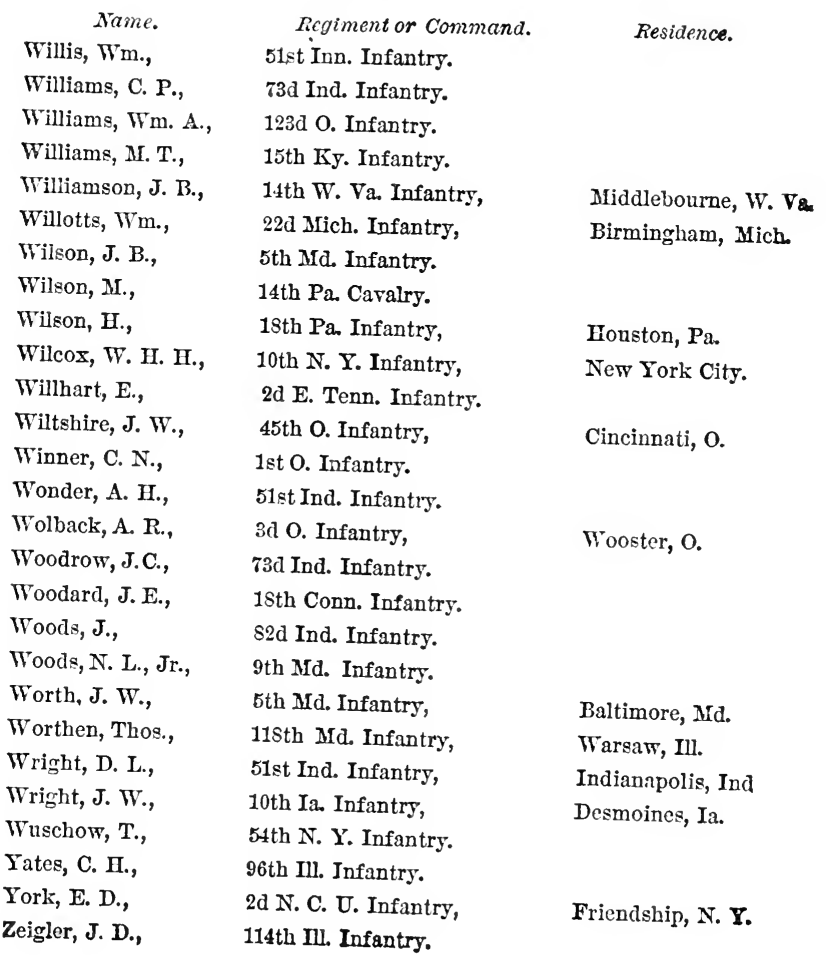




\section{ADDITIONAL LIST OF PRISONERS.*}

[The following is an additional list of officers captured during the spring, summer, autumn, and winter of 1S64, after the removal of the old prisoners from Richmond on the 7th of May. They were imprisoned at Macon, Sarannah, Charleston, Columbia, Charlotte, Raleigh, and Goldsboro'.]

\section{COLONELS.}

Name. Regiment or Command.

Residence.

Ashworth, J. H., Butler, T. H., Crooks, S. J.,

Frazier, J., Huey, Pennock, Miller, F. C., Shedd, W., White, Daniel,

Buffum, MI. P., Conyngham, J. B., Clancy, C. W., Leeds, M. A., MicCreary, D. B., SIoulton, O., MTorgan, Benj. B., 1st Ga. U. S. Infantry. 5th Ind. Cavalry, 22d N. Y. Cavalry, 140th Pa. Infantry, Sth $\mathrm{Pa}$. Cavalry, 147th N. Y. Infantry, 13th Ill. Infantry, 31st Me. Infantry, LIECTENANT-COLONELS. 4th R. I. Infantry,

Providence, R. I. 52d Pa. Infantry. 52d 0. Infantry, 153d O. Infantry, 145th $\mathrm{Pa}$. Infantry, Clifty, Ind. New York City. Canonsburg, Pa. Westchester, Pa. Oswego, N. Y. Aledo, Ill. Bangor, Me. 25th Mass. Infantry. 75th 0 . Infantry,

Smithfield, 0 . Bantam, 0 . Erie, $\mathrm{Pa}$.

Franklin, 0 . 
same.

Sawders, A. H, Stoughton, H. R., Thorp, T. J., Watson, C. C., Wallace, G., Von Helmrick, G.,
Regiment or Command. $2 d$ U. S. S. S. 6th Ind. Caralry, 47th O. Infantry, 16th Ia. Infantry, 1st N. Y. Dragoons, 4th Mo. Cavalry,

Residence.

Davenport, Iowa.

Almond, N. $Y$. Greencastle, Ind. Morning San, $O$.

St. Louis, MIo.

\section{MAJORS.}

Denny, W. N.,
Dewees, J. H.,
Dunn, M.,
English, D.,
Filler, J. H.,
Flemming, C. E.,
Forbcs, W. H.,
Fox, G. B.,
Hall, W. P.,
Harkness, R.,
Hasley, T. J.,
Isett, J. H.,
Kendall, W. M.,
Lernan, P. M.,
Lynch, C. M.,
Mattock, C. P.,
Nelson, P.,
Parsons, W. L.,
Pasco, H. L.,
Pratt, J. E.,
Quigg, D.,
Reynolds, W. H.
Smith, T. A.,
Sopcr, M. H.,
Speece, L. B.,
Steele, J.,
Thomas, D.,
Vickers, D.,
Wanner, G. G.,
Yonng, J. W.,
Hrang
51st Ind. Infantry,
13th $\mathrm{Pa}$ Cavalry,

19th Mass. Infantry.

11th Ey. Cavalry,

11th Vt. Infantry,

2d Mass. Cavalry.

75th O. Infantry,

6th N. Y. Cavalry,

10th Wis. Infantrs,

11th N. Y. Infantry,

Sth Ind. Cavalry,

73d Ind. Infantry,

22d N. Y. Cavalry,

145th $\mathrm{Pa}$ Infantry,

1ith Me. Infantry.

66th N. Y. Infantry,

$2 d$ Wis. Infantry.

16th Conn. Infantry,

4th Vt. Infantry,

14th Ill. Cavalry,

14th N. Y. Artillery,

5th Ind. Caralry,

7th $\mathrm{Pa} . \mathrm{V} . \mathrm{R}$. C.,

2d Pa. Cavalry,

155th O. Infantry,

4th N. J. Infantry,

24th N. Y. Cavalry,

76th N. Y. Infantry, 55th $\mathrm{Pa}$. Infantry,

7th Tenn. Cavalry,
Vincennes, Ind.

Philadelphia, $\mathbf{P a}$.

Owening, Ky.

Bedford, $\mathrm{Pa}$.

Bellows Falls, Vt.

Cincinnati, 0.

Brooklyn.

Elkhorn, Tis.

Wappello, Iowa.

Plymouth, Ind.

Memphis, N. Y.

Erie, Pa.

Westchester, N. Y.

Hartford, Conn.

Bennington, Vt.

Utica, N. Y.

Lexington, Tenn.

Sheldon, IIl.

Wilkesbarre, $\mathbf{P a}$.

Pittsburgh, $\mathrm{Pa}$.

Newark, 0.

Philadelphia, $\mathbf{P a}$

Rochester, N. Y.

Cherry Valley, N. Y.
Dover, N. J.

Bloomington, Ill. 


\section{CAPTAINS.}

Name.

Aigan, John,

Algbaugh, W. N.,

Alters, J. B.,

Amory, C. B.,

Andrews, H. B.,

Auer, M.,

Barrett, J. A.

Bayard, G. A.,

Baker, H. D.,

Baker, W. F.,

Barnum, S. D.,

Bartlett, O. E.,

Belger, James,

Bennett, B.,

Bennett, W. F.,

Benson, J. F.,

Benson A. N.,

Beebe, B. C.,

Biebel, H.,

Blanchard, Geo. A.,

Blise, A. T.,

Bostwick, N.,

Bowen, C. A.,

Boutwin, C. W.,

Bradley, G.,

Bremen, S.,

Brown, J. H.,

Bryant, J. W.,

Burdick, C. H.,

Burpee, E. A.,

Burbank, H. H.,

Call, C. H.,

Carr, J. P.,

Camp, T. B.,

Case, F. S.,

Carperts, L. M.,

Carpenter, E. N.,
Regiment or Command.

5th R. I. Artillery,

51st $\mathrm{Pa}$. Infantry,

75th O. Infantry,

A. A. Gen. U. S. Vols.,

17th Mich. Infantry.

15th N. Y. Cavalry,

7th $\mathrm{Pa}$. V. R. C.,

148th $\mathrm{Pa}$. Infantry.

120th IIl. Infantry,

87th Pa. Infantry,

$23 d$ U. S. C. T.,

31st Me. Infantry,

1st R. I. Artillery.

22d N. Y. Cavalry,

39th Ia. Infantry,

120th Ill. Infantry,

1st D. C. Cavalry.

13th Md. Infantry,

6th Conn. Infantry,

85th IIl. Infantry,

10th N. Y. Cavalry,

20th O. Infantry.

18th Conn. Infantry.

4th Vt. Infantry,

2d N. J. Infantry.

3d Mich. Infantry,

17th Ia. Infantry,

5th N. Y. Cavalry,

1st Tenn. Cavalry,

19th Me. Infantry,

32d Me. Infantry,

29th IIl. Infantry,

93d Ind. Infantry,

52d $\mathrm{Pa}$. Infantry,

2d 0. Cavalry,

18th Wis. Infantry.

6th Pa. Cavalry,
Residence.

Pawtucket, R. I.

Morristown, $\mathrm{Pa}$.

Spring Dale, $\mathbf{O}$.

Jamaica Plain, Mass.

Syracuse, N. Y.

Philadelphia, $\mathrm{Pa}$.

Golconda, Ill.

Gettysburg, $\mathrm{Pa}$.

North Rome, $\mathrm{Pa}$.

Showhegan, Me.

Hammondsport, N. Y,

Osceola, Iowa.

Vienua, Ill.

Seneca Falls, N. Y.

Bridgeport, Conn.

Havana, IIl.

Peterboro', N. X.

Chester, Vt.

Georgetown, Mich.

Desmoines, Iowa.

Washington, D. C.

Nashville, Tenn.

Rockland, Ne.

Limerick, Me.

Inkster, Mich.

Austin, Ind.

Camptown, $\mathrm{Pa}$.

Wellington, $\mathrm{O}$.

Germantown, $\mathbf{P a}$, 


\begin{tabular}{|c|c|}
\hline $\begin{array}{c}\text { Name. } \\
\text { Chalfant, J. T., }\end{array}$ & $\begin{array}{l}\text { Regiment or Command. } \\
\text { 11th } \mathrm{Pa} \text {. Infantry, }\end{array}$ \\
\hline Chauncey, C. R., & 34th Mass. Infantry, \\
\hline Chapin, H. C., & 4th Vt. Infantry, \\
\hline Clark, M. W., & 11th Ia. Cavalry, \\
\hline Clark, L. S., & 62d N. Y. Infantry, \\
\hline Clyde, J. D., & 76th N. Y. Infantry, \\
\hline Cole, A. F., & 59th N. Y. Infantry, \\
\hline Colville, J. W., & 5th Mich. Infantry, \\
\hline Coglin, T., & 14th N. Y. H. Artillery, \\
\hline Cooke, H. P., & A. A. Gen. U. S. Vols., \\
\hline Daniels, E. S., & 35th U. S. C. T., \\
\hline Davenport, T. F., & 75th O. Infantry. \\
\hline Davis, W. H., & 4th Md. Infantry, \\
\hline Davis, L. B., & 93d Ind. Infantry, \\
\hline Derrickson, J. G., & 66th N. Y. Infantry, \\
\hline Dennis, J. B., & 7th Conn. Infantry. \\
\hline Dirlan, C. J., & 12th O. Infantry, \\
\hline Dicey, E. C., & 1st Mich. S. S., \\
\hline Dibeler, J., & 45th $\mathrm{Pa}$. Infantry, \\
\hline Doane, E. B., & 8th O. Cavalry, \\
\hline Dodge, C. C., & 20th Mich. Infantry, \\
\hline Donohey, G. B., & 7th Pa. V. R. C. \\
\hline Downing, O. J., & 2d N. Y. Cavalry, \\
\hline Dusbrow, W., & 40th N. Y. Infantry, \\
\hline Duzenburgh, A., & 35th N. Y. Infantry. \\
\hline Eagan, M., & 15th W. Va. Infantry. \\
\hline Elder, S. S., & 1st U. S. Artillery. \\
\hline Evans, B. W., & 4th O. Cavalry, \\
\hline Evans, N. C., & 184th $\mathrm{Pa}$. Infantry, \\
\hline Fall, J. P., & 32d Me. Infantry, \\
\hline Farr, W. V., & 106th $\mathrm{Pa}$ Infantry. \\
\hline Fay, W. W., & 56th Mass. Infantry. \\
\hline Fiedler, J., & Eng. R. C. U. S. A. \\
\hline Fisk, W. M., & $73 d$ N. Y. Infantry. \\
\hline Flamsburg, O., & 4th Ind. Battalion. \\
\hline Ford, E. W., & 9th Mlinn. Infantry, \\
\hline Francis, J. L., & 135th O. Infantry. \\
\hline Funk, J. W., & 39th N. Y. Infantry, \\
\hline Galloway, J. L., & A. A. Gen. U. S. Vols., \\
\hline
\end{tabular}

\author{
Residence. \\ Pittsburgh, Pa. \\ Westfield, Mass. \\ Elmira, N. Y. \\ Columbus City, Iowa. \\ Saratoga Springs, N. Y \\ Cherry Valley, N. Y. \\ Lowville, N. Y. \\ East Saginaw, Mich. \\ Rochester, N. Y. \\ Deckartown, N. J. \\ Old Cambridge, Mass
}

Baltimore, Md.

Patriot, Ind.

New York City.

Clyde, 0.

Detrolt, Mich.

Bainbridge, Pa.

Salem.

Marshall, Mich.

Long Island, N. Y.

New York City.

Kirkersville, 0 .

Rainsburg, $\mathbf{P a}$.

South Berwick, Me.
Austin, Minn.

New York City. Pensacola, Fla. 


\section{Name.}

Gillespie, J. B., Gilbert, E. C., Gill, A. W. H., Goodrich, A. L., Grant, E., Grant, A., Green, E. H., Green, J. L., Grayhaur, P., Gutjahr, C., Harris, W., Hart, G. D., Hastings, C. W., Hayes, E., Hayden, J. A., Haines, H. A., Heer, T. A., Heltermus, J. B., Heinrod, P., Heck, F. W., Hitt, W. R., Hill, V. H., Hobbie, C. A., Hoyt, H. B., Hobart, M. C., Hodge, W. L. Holes, A. J., Huff, H. B., Hume, D. J., Hutchinson, R. C., Hymer, S., Ingledew, L., Jackson, C. G., Jenkins, H., Jobe, B. A., Jones, D., Jones, S. C., Johnson, J. D., Judson, S. C.,
Regiment or Comimand. 120th Ill. Infantry, 152d N. Y. Infantry, 14th N. Y. Infantry, sth N. Y. Cavalry, 1st Vt. Cavalry. 19th Wis. Infantry. 107th $\mathrm{Pa}$. Infantry, A. A. Gen. U. S. A., 51th $\mathrm{Pa}$. Infantry, 16th Ill. Infantry. 24th Mo. Cavalry, 5th Pa. Cavalry. 12th Mass. Infantry. 95th N. Y. Infantry, 11th Pa. V. R. C., 184th Pa. Infantry. 2Sth O. Infantry, 18th Ky. Infantry. 105th O. Infantry, 2d MId. Infantry, 13th Ill. Cavalry, 2d Md. Infantry, 17th Conn. I fantry, 140 th N. Y. I fantry, 7th Wis. Infantry, 120th Ill. Infantry, 37th Wis. Infantry. 184th Pa. Infantry, 19th Mass. Infantry, 8th Mich. Infantry. 115th Ill. Infantry, 7th Mich. Infantry, 84th $\mathrm{Pa}$. Infantry, 40th Mass. Infantry. 11th $\mathrm{Pa}$ V. R. C., 14th N. Y. Artillery, 7th N. Y. Artillery. 10th N. Y. Infantry, 106th N. Y. Infantry,
Residence.

Vienna, Ill.

Butternuts, N. Y.

Brooklyn, N. Y.

Churchville, N. Y.

Maytown, $\mathrm{Pa}$. Monroe, Mich.

Johnstown, $\mathrm{Pa}$.

Mount Vernon, Mo.

Sing Sing, N. Y.

Uniontown, $\mathbf{P a}$.

Tell City, Ind.

Waterford, $\mathbf{P a}$.

Baltimore, Md.

Urbana, $\mathrm{O}$.

Manchester, N. H.

Stamford, Conn.

Rochester, N. Y.

Fall River, Wis.

Golconda, Ill.

Altoona, Pa.

Boston, Mass.

Rushville, Ill. Janesville, Wis.

Berwick, Pa.

Salem Cross Roads, $\mathbf{P a}$ Utica, N. Y.

Hamisports, N. J. Ogdensburg, N. Y. 
Name.

Kessler, J. G.,

Kenyon, P. D.,

Kenfield, F.,

King, J. E.,

Latimer, E. C.,

Law, G.,

Little, J. S.,

Logan, W. S.,

Lyttle, C. W.,

May, J.,

Maish, L.,

Mattison, A. C.,

Manley, J. A.,

McCarty, W. W.,

McCray, H.,

McDonald, H. J.,

McFadden, W. M.,

McGraylis, M.,

McHugh, J. W.,

IcIntyre, -

McWitt, R. J.,

Netzger, J.,

Merrill, H. P.,

Melkhorn, MI.

Millard, R. J.,

Moors, N. H.,

Monre. Le Roy,

Morton f. W.,

Morgan, s. ML,

Murray, S. F.,

Midgett, A. G.,

Nash, W. H.,

Newsome, E.,

Newlin, C.,

Nichols, C. H.,

Nolan, L.,

Norton, E. E.,

Norris, J.,

Noyse, C. S.,
Regiment or Commaxd.

2d Ind. Cavalry.

15th Ill. Battalion,

17th Vt. Infantry,

103d Ill. Infantry,

27th U. S. C. T.,

6th W. Va. Cavalry,

143d $\mathrm{Pa}$. Infantry,

7th Mich. Infantry,

145th Pa. Infantry.

15th Mass. Artillery.

87th $\mathrm{Pa}$. Infantry,

12th N. Y. Infantry.

64th N. Y. Infantry.

1Sth 0 . Infantry,

115th $\mathrm{Pa}$. Infantry.

11th Conn. Infantry,

59th N. Y. Infantry.

93d Ind. Infantry.

69th $\mathrm{Pa}$. Infantry,

15th Wis. Infantry.

1st Pa. Cavalry,

55th $\mathrm{Pa}$. Infantry.

4th Ky. Infantry.

135th O. Infantry,

$2 \mathrm{~d} \mathrm{~Pa}$. Artillery,

7th N. Y. Artillery,

72d O. Infantry,

4th Mass. Cavalry.

A. A. Gen. U. S. Vols.,

$2 d$ U. S. S. S.,

11th Me. Infantry,

1st U. S. S. S.,

81st Ill. Infantry,

7th $\mathrm{Pa}$. Cavalry.

6th Conn. Infantry.

2d Del. Infantry.

24th Alich. Infantry,

$2 \mathrm{~d} \mathrm{~Pa}$. Artillery,

31st Me. Infantry,
Residence.

Mount Carroll, Ind.

Morristown, Vt.

Middleport, Ill.

Canton, $\mathrm{O}$.

Ellenboro', W. Va.

Nicholson, $\mathrm{Pa}$.

Richland, Mich.

York, Pa.

McConnellsville, $\mathbf{0}$.

Kingston, N. J.

Philadelphia, $\mathrm{Pa}$.

Milroy, $\mathrm{Pa}$.

Ada, $\mathrm{O}$.

Towersville, $\mathrm{Pa}$.

Albany, N. Y.

Fremont, $\mathrm{O}$.

Lind5, N. Y.

Candia, N. H.

Newbury, Me.

New York City.

Carbondale, Ill.

Detroit, Mich.

.Washington, D. C. Mount Desert, Me. 
Name.

Nutting, J. H.,

Nuhfer, A.,

Ogan, H. W.,

Parker, J.,

Paine, L. B.,

Paine, J. A.,

Paul, A. C.,

Pettit, G.,

Pendleton, D. B.,

Pemberton, H. V.,

Piggott, J. T., Jr.,

Pierce, S. C.,

Ping, T.,

Plase, W. H.,

Powell, J. P.,

Powers, D. H.,

Porter, D. M.,

Porter, B. B.,

Reed, -

Reynolds, W. J.,

Reynolds, W. J.,

Reir, Geo. W.,

Richards, R. C.,

Ritter, $\mathbf{H .}$,

Robinson, C.,

Roseneranz, A. C.,

Rourke, J.,

Sargent, II. R.,

Schooley, D.,

Schofield, E.,

Scott, D. W.,

Shurtz, E.,

Sherman, S. U.,

Shuttz, W.,

Skilton, A. S.,

Smart, G. F. C.,

Smith, H. J.,

Smith, J. H.,

Smith, A. B.,
Regiment or Command.

27th Mass. Infantry.

72d O. Infantry,

14th O. Infantry.

1st N. J. Infantry,

121st N. Y. Infantry,

2d Ind. Cavalry,

A. A. Gen. U. S. Vols.,

120 th N. Y. Infantry;

5th Mich. Cavalry,

14th N. Y. Artillery,

8th $\mathrm{Pa}$. Cavalry,

3d N. Y. Caralry,

17th Ia. Infantry,

87th U. S. Infantry,

146th N. Y. Infantry,

6th Mich. Cavalry.

120th Ill. Infantry.

10th N. Y. Artillery,

107th N. Y. Infantry.

75th O. Infantry.

4th R. I. Infantry,

107 th N. Y. Infantry.

45th $\mathrm{Pa}$. Infantry,

$52 d \mathrm{~N}$. Y. Infantry,

31st U. S. C. T.

4th Ind. Cavalry,

1st IIl. Artillery,

32d Me. Infantry,

2d $\mathrm{Pa}$. Artillery,

11th Pariv. R. C.,

23d U. S. C. T.,

8th Ia. Cavalry.

4th R. I. Infantry,

37th O. Infantry,

57th 0 . Infantry.

145th Pa. Infantry,

53d Pa. Infantry,

16th Ia. Infantry,

4Sth Ill. Infantry.
Residence.

Woodville, O.

Trenton, N. J.

Garratsville, N. Y.

Bridgetown, Ind.

Newport, Ky.

Lexington, N. Y.

Detroit, Mich.

New York City.

Philadelphia, $\mathrm{Pa}$.

Rochester, N. Y.

Ashland, Iowa.

Dayton, $\mathrm{O}$.

Clinton, N. Y.

Taylor, N. Y.

Wickford, R. I.

Ontario, N. $\mathbf{Y}$.

Philadelphia, $\mathrm{Pa}$.

Eransville, Ind.

Milwaukie, Wis.

Portland, Me.

Pittston, $\mathrm{Pa}$.

Brookville, $\mathbf{P a}$.

Pottsville, $\mathrm{Pa}$.

Providence, R. I.

Toledo, O.

West Greenville, $\mathrm{Pa}$

Huntingdon, $\mathbf{P a}$.

Lyons, Iowa. 
Name.

Snodgrass, J. G.,

Snyder, J.,

Spencer, S. A.

Stevens, J. R.,

Stewart, R. T.,

Stansbury, M. L.,

Strang, H. W.,

Sutcher, C. B.,

Swan, E. J.,

Swift, R. R.,

Tibbles, H. G.,

Tilbrand, H.,

Timbson, S. C.,

Thompson, J.,

Turner, J. H.,

Tyler, L. D. C.,

Underwood, J. W.,

Uffar, H. A,

Unthank, C. L.,

Vaughn, Z.,

Van Haack, A.,

Von Keiser, A.,

Washburn, W.,

Wakefield, H. B.,

Walpole, H. H.,

Wall, Mr. W.,

West, J. H.,

Westbrook, C. S.,

Webb, G.,

Whittaker, E. B.,

Willis, A. R.,

Wilson, W. M., Jr.,

Wilson, J.,

Williams, R.,

Wiley, M.,

Wright, B. F.,

Wright, R. J.,

Wyman, E. T.,

Young, D. G.,

Zarracher, F. K.,
Regiment or Command.

110th O. Infantry,

14th N. Y. Infantry,

82d Ind. Infantry.

40th N. Y. Infantry,

13Sth $\mathrm{Pa}$. Infantry,

95th O. Infantry.

30th $\mathrm{Il}$. Infantry,

16th Ill. Infantry.

76th N. Y. Infantry,

27th Mass. Infantry,

12th O. Infantry,

4th N. H. Infantry.

95th N. Y. Infantry,

4th O. Caralry.

16th Ia. Infantry,

106th $\mathrm{Pa}$ Infantry,

57th $O$. Infantry.

A A Gen. U. S. Vols.

11th Ky. Caralry.

1st Me. Cavalry,

6sth N. Y. Infantry.

30 th N. Y. Battery.

35th Mrass. Infantry,

55th Ind. Infantry,

122d N. Y. Infantry,

69 th N. Y. Infantry.

11th Бy. Infantry.

135th O. Infantry,

2d $\mathrm{Pa}$. Artillery,

72d $\mathrm{Pa}$. Infantry.

Sth Me. Infantry,

122d O. Infantry,

57th 0 . Infantry.

12th O. Infantry,

1st Tenn. Infantry.

146th N. Y. Infantry,

6th O. Infantry,

81st Ill. Infantry,

18th Pa. Cava.ry,
Residence.

New Madison, 0.

Heurelton, N. Y.

Brooklyn, N. Y.

Morristown, $\mathrm{Pa}$.

Collins Station, $\mathbf{I l}$.

Cherry Valley, N. Y.

Springfield, Mrase.

Dayton, $\mathrm{O}$.

New York City.

Mruscatine, Iowa.

Philadelphia, $\mathrm{Pa}$.

Freeman, Me.

Boston, Mass.

Azalia, Ind.

Syracuse, N. Y.

Zanesville, $\mathrm{O}$.

Murcy, $\mathrm{Pa}$.

Biddeford, Me.

Zanesville, $O$.

Daston, $\mathrm{O}$.

Utica, N. Y.

Springfield, $\mathrm{O}$.

Augusta, Me.

De Soto, Ill.

Philadelphia, $\mathbf{P a}$ 


\section{LIEUTENANTS.}

Name.

Abbey, A. L.,

Abbott, A. O.,

Abbott, E. A.,

Adams, J. G. B.,

Adams, W. C.,

Afllee, E. T.,

Alexander, E. P.,

Allen, Robert,

Alden, G. C.,

Anderson, H. M.,

Anderson, J. F.,

Appleget, A. S.,

Austin, G. A.,

Baldwin, C. W.,

Barker, H. E.,

Barton, J. L.,

Barnes, A. T.,

Barringer, A.,

Bateman, Wm.,

Baird, Wm.,

Barnard, W. A.,

Beasley, J. L.,

Beecham, R. K.,

Bearce, H. M.,

Bell, C. A.,

Beebee, H. E.,

Bigley, C. H.,

Bixby, H. H.,

Bishop, E. P.,

Biller, J. N.,

Blane, W.,

Blasse, Wm.,

Blickenhoff, Mr.,

Bosford, W. R.,

Boyd, W. J.,

Bowen, C. T.,

Bowley, F. S.,
Regiment or Command.

8th Mich. Cavalry,

1st N. Y. Dragoons,

2d O. Veterans,

19th Mass. Infantry,

2d Ky. Cavalry,

26th Mich. Infantry,

2d N. J. Dragoons.

112th Ill. Infantry,

3d Me. Infantry.

2d Pa. Artillery,

2d N. J. Cavalry,

14th Ill. Battalion,

$2 d$ N. J. Infantry,

22d N. Y. Cavalry.

49th Pa. Infantry.

Ill. Veterans.

44th N. Y. Infantry,

9th Mich. Cavalry,

$23 d$ U. S. C. T.,

20th Mich. Infantry,

s1st Ill. Infantry,

23d U. S. C. T.,

32d Me. Infantry,

A. D. C. U. S. Vols.

22d N. Y. Cavalry.

$82 d$ N. Y. Infantry.

9th Me. Infantry,

4th Tenn. Cavalry.

$2 \mathrm{~d} \mathrm{~Pa}$. Artillery,

43d N. Y. Infantry,

43d N. Y. Infantry,

$42 \mathrm{~d} N$. Y. Infantry,

1st N. Y. Infantry.

5th Mich. Cavalry. •

4th R. I. Infantry,

30th U. S. C. T.,
Residence.

Armada, Mich.

Almond, N. Y.

Olmstead's Fall, O.

Groveland, Mass.

Star Furnace, Ky.

Bridgeport, $\mathbf{O}$.

Detroit, Mlich.

Annawan, Ill.

Philadelphia, $\mathrm{Pa}$.

Hightstown, $\mathrm{Pa}$.

Woodstock, Ill.

New York City.

Nassau, N. Y.

Ypsilanti, Mich.

North Rome, $\mathrm{Pa}$.

Lansing, Mich.

Fredonia, Ill.

Sun Prairie, Mo.

West Minot, Me.

Norridgewock, Me.

Martinsburg, W. Va

Albany, N. $Y$.

Albany, N. Y.

New York City.

Wickford, R. I.

Worcester, Mass. 
Name.

Boettger, C.,

Braiday, Count S.,

Braidy, A. J.,

Brady, W. H.,

Brown, C. A.,

Brown, C. O.,

Briston, J. H.,

Breon, J.,

Briscoe, A. Mr.,

Brum, S.,

Bryan, J. H.,

Bulow, A,

Burns, M.,

Buchanan, W.,

Burkholder, D. W.,

Burnett, G. M.,

Burton, R.,

Burrows, S. W.,

Buckley, H.,

Campbell, L. A.,

Campbell, W. F.,

Carr, C. W.,

Casler, J. L.,

Caldwell, J. S.,

Carlisle, L. B.,

Chase, D. L. Jr.,

Case, M. B.,

Casey, J.,

Carter, W. H.,

Canney, W. H.,

Cameron, J. F.,

Califf, B., F.,

Cashell, C. P.,

Chnte, R. H.,

Chapin, H. A.,

Chahill, W.,

Chase, H. R.,

Chubbuck, D. B.,

Charters, A. M.,
Regiment or Command.

2d Md. Infantry,

2d N. J. Cavalry,

54th $\mathrm{Pa}$. Infantry.

2d Del. Infantry,

1st N. Y. Artillery.

31st Me. Infantry,

1st Conn. Cavalry.

145th $\mathrm{Pa}$ Infantry,

Coles' Mid. Cavalry,

81st IIl. Infantry.

1s4th $\mathrm{Pa}$. Infantry,

3d N. J. Cavalry.

13th N. Y. Cavalry.

76th N. Y. Infantry,

7th $\mathrm{Pa}$. Infantry,

4th Ind. Cavalry,

9th N. Y. Artillery.

1st N. Y. Fet. Caralry.

4th N. H. Infantry.

153d N. Y. Infantry,

51st Pa. Infantry,

4th $\Gamma$ t. Infantry.

76th N. Y. Infantry,

16th Ill. Cavalry,

145th $\mathrm{Pa}$. Infantry,

102d N. Y. Infantry,

$23 d$ U. S. C. T.,

45 th N. $\Gamma$. Infantry,

5th Pa. V. R. C.,

69th N. Y. Infantry,

5th $\mathrm{Pa}$ Caralry,

12th Pa. Caralry.

59th Mass. Infantry,

95 th N. Y. Infantry.

76th N. Y. Infantry,

1st Vt. H. Artillery,

19th Mass. Infantry.

17th Ia. Infantry,
Restdence.

Baltimore, Md.

Vienna, Austria

Wilmington, Del.

Mroro, Me.

Potter's Mills, $\mathrm{Pa}$

Baltimore, Ma.

Harrisburg, $\mathrm{Pa}$.

Cohoes, N. Y.

Shippensburg, $\mathrm{Pa}$

Terre Haute, Ind.

Cherry Valley, N. Y

Slifer, $\mathrm{Pa}$.

Otsego, N. Y.

Chicago, Ill.

Luthersbarg, $\mathrm{Pa}$

Lansing, Mich.

Ottawona, Minn.

Tuckahoe, N. Y.

Elimsport, $\mathrm{Pa}$

New York City.

Philadelphia, $\mathrm{Pa}$.

Salem, Hass.

Chelsea, Mass.

Solon, N. Y.

Guilfort Centre, Vt.

Learenworth, Kan. 
Name.

Channell, J. R.,

Chesman, H.,

Chittendon, J. L.,

Clark, J. W.,

Clark, J. H.,

Clark, II. L.,

Clegg, Mr.,

Clemmens, $\mathrm{T}$.,

Cline, D. J.,

Coslett, C.,

Cooper, R.,

Cook, W. C.,

Coffin, V. L.,

Codington, J. P.,

Correll, H.,

Cope, J. D.,

Core, J. W.,

Colter, W. J.,

Conover, W. H.,

Conn, C. G.,

Corum, Geo.,

Copeland, W. A,,

Copeland, C. D.,

Crawford, C. H.,

Cromack, S. O.,

Creacy, G. W.,

Cribben, H.,

Crossley, S.,

Cramer, C. P.,

Cutter, C. H.,

Curtis, G. M.,

Curtis, W. H.,

Cunningham, J.,

Cunningham, M.,

Cunningham, M.,

Damrell, W. S.,

Davis, W. G.,

Davidson, J. W.,

Doan, S. V.,
Regiment or Command.

1st IIl. Artillery,

7th Ind. Infantry,

5th Ind. Cavalry,

59th N. Y. Infantry,

1st Mass. Artillery,

2d Mass. Artillery,

5th Ind. Cavalry.

13th Ill. Infantry.

75th O. Infantry,

115th Pa. Infantry,

7th N. J. Infantry,

9th Mich. Cavalry,

31st Me. Infantry,

8th Ia. Cavalry,

2d Vt. Infantry,

116th Pa. Infantry,

6th W. Va. Cavalry.

15th Mass. Infantry,

$22 d$ N. Y. Cavalry,

1st M. S. S.

2d Ky. Cavalry,

10th Mich. Infantry.

5sth Pa. Infantry,

18sth Pa. Infantry,

77th N. Y. Infantry,

35th Mass. Infantry,

140th N. Y. Infantry,

118th Pa. Infantry,

21st N. Y. Cavalry,

95th N. Y. Infantry,

140th N. Y. Infantry,

19th Mass. Infantry,

7th Pa. V. R. C.,

$42 \mathrm{~d} N$. Y. Infantry,

1st Vt. H. Artillery.

13th Mass. Infantry,

27th Mass. Infantry.

95th O. Infantry,

145th Ia. Infantry,
Residence.

Ottawa, Ill.

Cincinnati, 0.

Knoxville, Tenn.

Butler, 0.

Boston, Mass.

Rochester, N. Y.

Logan Hocking, $\mathbf{O}$.

Philadelphia, $\mathrm{Pa}$.

Jersey City, N. J.

Tecamseh, Mich.

Harrington, Me.

Dubuque, Iowa.

New Haven, Conn.

Uniontown, $\mathrm{Pa}$.

Clinton, Mass.

Norwich, N. Y.

Greenupsburg, $\mathbf{P a}$

Fall River, Mass.

Philadelphia, $\mathrm{Pa}$.

Bennington, Vt.

Newburyport, Masa.

Rochester, N. Y.

Philadelphia, $\mathrm{Pa}$.

West Troy, N. Y.

Boston, Mass.

Rochester, N. Y.

Randolph, Mass.

Leesport, $\mathrm{Pa}$.

Norwich, Conn.

Boston, Mass.

Big Plains, 0 .

West Springfleld, $\mathbf{P a}$ 
Name.

De Lay, R.,

Demmick, O. W.,

Diffenbach, W. B.,

Dick, L.,

Dickenson, E.,

Dorr, H. G.,

Dorris, W. C.,

Donovan, J.,

Dodge, H. G.,

Downs, C.,

Downing, H. A.,

Dorfee, W. H.,

Drennan, J. S.,

Driscoll, D.,

Drake, J. M.,

Drew, G. H.,

Dunn, J.,

Dunning, A. J.,

Dunn, J.,

Durboyne, G.,

Dyer, E. B.,

Eastman, P. R.,

Eagan, John,

Eckings, " T. K.,

Elkin, J. L. F.,

Elder, John,

Evang, T. E.,

Everett, Chas.,

Eyestone, J. W.,

Fairbanks, J.,

Faye, E. M.,

Fagan, C. A.,

Fatzer, S.,

Fales, L. D. C.,

Faas, Louis,

Ferris, J. M.,

Finney, G. E.,

Finney, D. S.,

Fisher, L. W.,
Regiment or Command.

4th Ia. Cavalry,

11th N. H. Infantry,

7th Pa. V. R. C.,

72d O. Infantry,

44th Wis. Infantry.

4th Mass. Cavalry,

11th Ill. Infantry.

$2 \mathrm{~d}$ N. J. Infantry,

2d Pa. Cavalry,

33d N. J. Infantry,

31st U. S. C. T.,

- R. I. Infantry,

1st Vt. Artillery,

24th Mo. Infantry,

12th N. J. Infantry,

9th N. H. Infantry,

61th N. Y. Infantry,

7th N. Y. Artillery.

5th N. H. Infantry,

60 th N. Y. Infantry.

1st Conn. Cavalry,

2d Pa. Cavalry,

1st U. S. Artillerg.

$3 \mathrm{~d}$ N. J. Infantry.

1st N. J. Infantry,

8th Ind. Infantrs.

52d Pa. Infantry,

70th O. Infantry,

13th Ind. Infantry,

72d O. Infantry,

42d N. Y. Infantry,

11th Pa. V. R. C.,

108th N. Y. Infantry,

14th N. Y. Artillery,

3d Mich. Infantry.

19th Ind. Infantry,

14th Ill. Infantry,

4th Vt. Infantry,
Residence.

Centerville, Iowe.

Strafford, Vt.

Huntingdon, $\mathrm{Pa}$.

Fremont, $\mathrm{O}$.

Boston, Mass.

Eizabeth, N. J.

Philadelphia, $\mathrm{Pa}$.

Patterson, N. J.

Poughkeepsie, N. Y.

Newport, R. I.

Morrisville, Vt.

Cannonsburg, Mich.

Trenton, N. J.

Milford, N. H.

New York City.

Keene, N. H.

Derby, Conn.

Mount Clemens, Mich.

New Brunswick, N. J.

Hyde Park, Pa.

Cleveland, O

Washington, Iowa.

Rollersville, $\mathrm{O}$.

New York City.

Ebensburg, $\mathrm{Pa}$.

Rochester, N. Y.

Attica, N. Y.

Elizabeth, Ind.

Beardstown, Ill.

Danville, $\mathbf{v t}$. 
Name.

Flannery, D.,

Fisher, S., Fitzpatrick, D., Fluger, G. W., Forney, D., Foster, H. C., Foley, John, Fontaine, E., Fowler, H. M., French, H., Frost, R. C., Furgeson, J., Gallagher, J., George, G. J., Gottshell, J., Goodown, J. M., Goodwin, J. A., Gordon, C. O., Gordon, H. M., Goss, J. W., Godley, M. L., Grant, H. D., Granger, C. MI., Green, E. A., Grey, Phillip, Griffen, T., Gunn, T. Mr., Hall, A. M., Uall, R. F., Hart, E. R., Maight, J. T., Uazel, E. J., Uazelton, D. W., Hastings, G. L., Hastings, J. L., Hamilton, H. N., Harrey, J. L., IIadley, H. V., IIallett, M. V. B.,
Regiment or Command. 4th N. J. Infantry, . 93d Ind. Infantry. 146th N. Y. Infantry, 11th Pa. V. R. C., 30th O. Infantry, 23d Ind. Infantry, 59th Mass. Infantry, 7th $\mathrm{Pa}_{2}$ V. R. C., 15th N. J. Infantry, 3d Vt. Infantry, 9th Mich. Cavalry, 1st N. J. Infantry, 4th O. Veterans, 40th Ill. Infantry. 56 th Pa. Infantry. 12th Ind. Infantry, 1st Mass. Cavalry, 1st Mre. Cavalry, 143d $\mathrm{Pa}$ Infantry, 1st Mrass. Artillery, 17th Ia. Infantry, 117 th N. Y. Infantry. 8sth N. Y. Infantry. 81st III. Infantry. $72 \mathrm{~d} \mathrm{~Pa}$ Infantry. 55th U. S. C. T., 21st Ky. Infantry, 9th Minn. Infantry. 75th O. Infantry, 1st Vt. Artillery, 8th Ia. Cavalry, 6th $\mathrm{Pa}$. Cavalry, 22d N. Y. Cavalry, 24th N. Y. Battery, 7th Pa. V. R. C., 59th N. Y. Infantry, 2d Pa. Artillery, 7th Ind. Infantry, 2d Pa. Cavalry,
Residence.

Trenton, N. J.

Brooklyn, N. Y.

Butler, $\mathrm{Pa}$.

Coshocton, $\mathrm{O}$.

Jeffersonville, Ind.

Boston, Mase.

Washington, D. C.

Newark, N. J.

Hartford, Conn.

Albion, Mich.

Philadelphia, $\mathrm{Pa}$.

Brookfield, Vt.

Fort Wayne, Ind.

Medford, Mass.

Phillips, Mre.

Shickshinny, $\mathrm{Pa}$.

Inswich, Mass.

Ashland, Iowa.

Pulaski, Ill.

Shelbyville, Ky.

Cincinnati, 0.

Danvers, Mass.

Tipton, Iowa.

Baltimore, MId.

Peterboro, N. Y.

Albany, N. Y.

Salona, $\mathrm{Pa}$.

Belleville, $\mathbf{O}$.

Philadelphia, $\mathrm{Pa}$.

Indianapolis, Ind.

Osceola, Pa. 
Name.

Havens, D.,

Hays, C. A.,

Harris, J. W.,

Hackett, A. N.,

Hand, S. P.,

Haywood, L. E.,

Herbert, $\mathrm{R}$,

Hedges, S. P.,

Hewett, J.,

Heston, J.,

Heffelfinger, J.,

Henry, A. J.,

Herzberg, P.,

Hendryks, W. H.,

Henderson, R.,

Hill, G. W.,

Hill, O. M.,

Hinds, ㅍ. C.,

Higley, E. H.,

Hodge, J. F.,

Horton, S. H.,

IIolden, E.,

Hopper, J.,

Holland, W. R.,

Holaham, C. P.,

Hoyt, W. H.,

Hoalladay, V. G.,

Hopf, Geo.,

Hograe, J. W.,

Hurd, W. B.,

Burt, C. O.,

IIull, G. N.,

IIughes, R. M.,

Huston, J.,

Hurst, T. B.,

Huntington, E. S.,

Isham, A. B.,

Jacks, J.,

Jenkins, G. W.,
Regiment or Command.

S5th IIl. Infantry,

11th $\mathrm{Pa}$. Infantry,

2d Ind. Cavalry,

101st O. Infantry,

$43 d$ U. S. C. T.,

5sth Mass. Infantry.

50th $\mathrm{Pa}$. Infantry,

112th N. Y. Infantry,

105th $\mathrm{Pa}$. Infantry.

4th N. J. Infantry,

7th Pa. V. R. C.,

120th Ill. Infantry.

66th N. Y. Infantry,

11th Mich. Battery.

1st Mass. Artillery,

7th Mich. Cavalry,

1st Mo. Artillery.

102d N. Y. Infantry,

1st Vt. Cavalry,

55th Pa. Infantry.

101st Pa. Infantry.

1st Vt. Cavalry,

2d N. Y. Cavalry,

5th Md. Cavalry.

10th Pa. Cavalry,

16th Ia. Infantry,

2d Ind. Cavalry,

2d MId. Infantry,

4th Pa. Cavalry.

17th Mich. Cavalry,

5th Me. Battery.

13th O. Infantry.

14th Ill. Cavalry,

95th O. Infantry,

7th Pa. V. R. C.,

11th U. S. Infantry.

7th Mich. Cavalry,

15th W. Va. Infantry.

sth W. Va. Infantry,
Residence.

Manito, III.

Eagle, $\mathbf{P a}$

Terre Haute, Ind.

Masillon, $\mathrm{O}$.

Binghamton, N. Y.

Lrebanon, $\mathrm{Pa}$.

Jamestown, N. Y.

Sing Sing, N. Y.

Mechanicsburg, $\mathrm{Pa}$.

New York City.

Lawrence, Mass.

Detroit, Mich.

Richfield Springs, N. $\mathbf{Y}_{\text {. }}$

Castleton, Vt.

Barre, Vt.

Scranton, $\mathrm{Pa}$.

Philadelphia, $\mathrm{Pa}$.

Camanche, Iowa.

Wintersett, Ind.

Baltimore, MId.

Jackson, Mich.

Vandalia, Ill.

Clay Lick, $\mathrm{O}$.

Dillsburg, $\mathrm{Pa}$.

Detroit, Mich.

Portland, O. 
Name.

Johnson, J. W., Johnson, H. A., Johnson, G. K., Jones, Alfred, Justus, J. C., Kendrick, E., Kendrick, R. H., Kerr, S. C., Kendall, H. T., Kelly, A. Kelly, J. MI., Kelley, J. R, Keen, J., Kennedy, J. D., Kempton, J. P., Kempton, F. H., Kenyon, G. C., Keheart, J., Kellow, J., Kidd, J. H., 太idder, G. C., King, Abe, Kibby, G. I., Knox, G., Knox, J. C., Krohn, P., Laycock, J. B., Larabee, W. H., Laid, J. O., Laid, M., Lane, L. Mr., Lamson, T. D., Lawrence, G. K, Lewis, C. E., Lee, A, Lewry, D. W., Lemon, M. W., Limbard, A, Long, C. H.,
Regiment or Command.

1st Nass. Artillery. 3d Me. Infantry.

1st Mie. Cavalry. 50th $\mathrm{Pa}$. Veterang, 2d Pa. V. R. C., 10th N. J. Infantry, 25th Wis. Infantry, 125th O. Infantry, 50th Pa. Infantry, 126th O. Infantry, 4th Tenn. Infantry, 1st $\mathrm{Pa}$. Cavalry, 7th Pa. V. R. C., Sth O. Cavalry, 75th O. Infantry. 5sth Mass. Artillery. 17th IIl. Infantry. 13th O. Infantry, 2d Pa. Artillery, 1st Md. Artillery, 113th $\mathrm{Pa}$. Infantry, 12th O. Infantry, 4th R. I. Infantry, 109th $\mathrm{Pa}$. Infantry, 4th Ind. Cavalry, 5th N. Y. Cavalry, 7th Pa. V. R. C. 7th Me. Infantry, 35th U. S. Infantry. 16th Ia. Infantry, 9th Minn. Infantry.

3d Ind. Cavalry, $2 d$ N. Y. Mounted Rifles, 1st N. Y. Dragoons, $152 \mathrm{~d}$ N. Y. Infantry, $2 \mathrm{~d} \mathrm{~Pa}$. Artillery. 14th N. Y. Artillery, - O. Cavalry, b9th Mass. Infantry.
Residence.

Methuen. Mass.

Reading, $\mathrm{Pa}$. Philadelphia, $\mathbf{P a}$. New York City. Potosi, Wis. Salineville, 0 . Reading, $\mathrm{Pa}$. Barnesville, 0 . Athens, Tenn. Patterson, $\mathrm{Pa}$. Bart, $\mathrm{Pa}$. Piqua, $O$.

Russell Station, $\mathbf{O}$. Honesdale, $\mathrm{Pa}$. Port Deposit, Md. Danton, Ill. Xenia, 0. Providence, R. I. Philadelphia, $\mathrm{Pa}$. Ladoga, Ind. Oswego, N. Y.

Portland, Me.

Desmoines, Iowa

Verny, Ind. Buffalo, N. Y. Nunda, N. Y. Utica, N. Y.

Canton, N. Y. Dephos, $\mathbf{O}$. 
Name.

Lond, E. D. C., Luther, J. C., Ludwig, MI. S., Lyman, H. H., Lyman, J., Lynn, J. L., Mather, F. W., Mather, E., Mangus, H. F., Mathews, A. D., Mathews, W. F., Mallison, J., Mayer, G. W., Marshland, A. J., Marshall, J. D., McCutcheon, E. T. McCain, J. C., IfCormick, J., McDonald, C., MicGeehan, J., McGinnes, W. A., McGuire, T., IICIntosh, J. C., MIcKage, J., McLanghlin, J., Miclane, McMranus, P. W., Ifcliahon, E., McNure, A., McNettervill, w., McWain, E. J., Menier, N. J., Mitchell, H. W., Mitchell, H. G., Miller, J. W., Miller, H., Mix, W. H., Mockrie, P. B., SIonaghan, J.,
Regiment or Cominand. 2d Pa. Artillery, 1st Pa. V. R. C., 53d $\mathrm{Pa}$. Infantry, 147th N. Y. Infantry, 27th Mass. Infantry, 145 th $\mathrm{Pa}$. Infantry, 7th N. Y. Artillery, 1st Vt. Caralry, 53d $\mathrm{Pa}$ Infantry, 1st $\nabla t$. Artillery, 1st Mrd. Infantry, 94th N. Y. Infantry, 37th Ind. Infantry, 2d Pa. Artillery, 57th Ohio Infantry, 64th N. Y. Infantry, 9th Minn. Infantry, 21st N. Y. Cavalry, 2d Ill. Artillery, 146th N. Y. Infantry, 19th Mass. Infantry, 7th III. Infantry, 145th $\mathrm{Pa}$ Infantry, 1s4th Pa. Infantry, 53d $\mathrm{Pa}$. Infantry, 9th Minn. Infantry. 27th Mass. Infantry, 72d O. Infantry. 73d $\mathrm{Pa}$ Infantry, 12th U. S. Infantry. 1st N. Y. Artillery, 93d Ind. Infantry, 14th N. Y. Infantry. 32d Me. Infantry, 14th Ill. Cavalry, 17th Mich. Infantry 19th U. S. C. T., 7th N. Y. Artillery, 62d Pa. Infantry,
Residence. Philadelphia, $\mathbf{P a}$. Ridgeway, $\mathrm{Pa}$. Philadelphia, $\mathrm{Pa}$. Pulaski, N. Y. East Hampton, Mace West Greenville, $\mathrm{Pa}$. Albany, N. Y. Fair Haven, Vt. Winfield, $\mathrm{Pa}$. Brownington, $\mathrm{Vt}$. Martinsburg, W. Va. Brandon, Wis. Lawrenceburg, Ind. Nicetown, $\mathrm{Pa}$. Wapakouratta, $O$. Gowanda, N. Y. Logansport, Ind. Troy, N. Y. Tamaroa, IIl Brooklyn, N. Y. Boston, MIass. St. Charles, IIl. Erie, $\mathrm{Pa}$ Hollidaysburg, $\mathrm{Pa}$ James' Creek, $\mathrm{Pa}$.

Davenport, Iowa.

Philadelphia, Pa

Rochester, Vt.

Leopold, Ind.

Portland, Me. Lincoln, Ill. Detroit, Mich. Warsaw, N. Y. Albany, N. Y. New York City。 
Name.

Morse, A., Morris, J. H., Morton, G. C., Mrufley, S. F., Murphey, J., Mullegan, J. A., Munger, T. J., Nelson, A. Needham, J. B., Neal, A., Nealy, O. H., Neher, W., Niedenhoffen, C., Niswander, D. MI., Noggle, H. L., Norwood, J., Nulland, W. R., Nyman, H. J., O'Connell, P., Ogden, J., O'Harre, J., Oliphant, D., Olden, G. C., O'Shea, E., Osborne, F., Outcolt, R. V., Parker, J. T., Parker, G. M., Parker, E. B., Partridge, W. H., Patterson, G. W., Palmer, J. H., Peake, D. S., Pentzell, D., Petry, J. C., Peters, G., Peck, W. D., Perrin, Z., Phinney, A.,
Regiment or Command. 1st Vt. Artillery, 4th Ky. Infantry. 4th Pa. Cavalry. 184th $\mathrm{Pa}$. Infantry, 69th N. Y. Infantry, 4th Mass. Cavalry, 37th Wis. Infantry, 66th N. Y. Infantry, 4th Vt. Infantry, 5th Ind. Cavalry. 11th U. S. Infantry, 9th Pa. V. R. C., 9th Minn. Infantry, 2d Pa. Artillery, 2d U. S. Infantry, 76th N. Y. Infantry, 5th Ind. Cavalry, 19th Mich. Infantry. 55th Pa. Infantry, 1st Wis. Cavalry, 7th N. Y. Artillery, 35th N. J. Infantry. 112th IIl. Infantry. 13th $\mathrm{Pa}$. Cavalry, 19th Mass. Infantry, 135th O. Infantry. 13th Ia. Infantry, 45th IIl. Infantry, 1st Vt. Artillery. 67th N. Y. Infantry, 135th O. Infantry, 12th O. Infantry, 85th N. Y. Veterans, 4th N. Y. Cavalry. 95th O. Infantry, 9th N. J. Infantry,

72d O. Infantry, 90th Ill. Infantry,
Residence.

Fayetterille, Vt.

Howard, $\mathrm{Pa}$. Newark, N. J. Biddeford, Me. Madison, Wis. Westchester, N. Y. Shrewsbury, Vt.

Boston, Mass. Philadelphia, $\mathbf{P a}$. Winona, Minn. Welch Run, Pa. Janesville, Wis. Slaterville, N. Y. Lafayette, Ind.

Johnstown, Pa. Winona, Minn. Cohoes, N. Y.

Philadelphia, Pa. Byfield, Mass.

Sigourney, Iowa. Carmi, IIl.

Brooklyn, N. Y. Alexander, $\mathbf{O}$. Ripley, $\mathbf{O}$. Hinsdale, N. Y.

London, $\mathrm{O}$. Elizabeth, N. J. Syracuse, N. Y. Clyde, O. Rockford, Ill. 
Name.

Phillips, W. B.,

Pinchenpangh, A. C., Pioquet, H.,

Piffarà, D. H.,

Pierce, H. H.,

Pierce, Worthington,

Pierson, E. C.,

Pierscn, M. P.,

Pierson, A. P.,

Pitt, G. W.,

Pitt, J. H.,

Platt, S. H.,

Powell, W. H.,

Post, James,

Porter, L. G.,

Pope, W. A.,

Poindexter, C. O.,

Provine, W. N.,

Price, C. A.,

Price, J. C.,

Price, Chas. A.,

Preston, A. L.,

Purveance, J. S.,

Purcell, T.,

Pyne, D. B.,

Rahn, O.,

Raymond, H. W.,

Ramsey, E. K.,

Rathbone, T. W.,

Raynor, A. J.,

Rainer, L.,

Randall, W. H.,

Rees, MI.,

Reed, J. H.,

Reode, J.,

Richards, L. S.,

Richards, J. M.,

Rienecker, G.,

Riley, I. H.,
Regiment or Commanal.

2d Pa. Artillery,

6th W. Va. Infantry,

32d III. Infantry,

14th N. Y. Infantry,

7th Conn. Infantry,

17th $\nabla$ t. Infantry,

85th N. Y. Veterans,

190th N. Y. Infantry,

9th Mich. Cavalry.

85th N. Y. Veterans,

118th N. Y. Infantry,

34th Mass. Infantry;

2d Ill. Artillery.

149th $\mathrm{Pa}$. Infantry,

81st Ill. Infantry,

18th Wis. Infantry.

31st Me. Infantry,

84th Ill. Infantry,

5th Mich. Infantry,

75th O. Infantry.

3d Mich. Infantry,

sth Mich. Cavalry,

130th Ind. Infantry,

16th Ia. Infantry,

3d Mo. Infantry,

1S4th $\mathrm{Pa}$. Infantry,

8th N. Y. Artillery,

1st N. J. Infantry,

153d 0 . Infantry.

19th U. S. C. T.,

2d N. J. Cavalry,

1st Mich. S. S.,

72d O. Infantry,

120th Ill. Infantry.

57th Mass. Infantry,

1st $\nabla$ t. Artillery,

1st W. Va. Infantry,

5th $\mathrm{Pa}$. Cavalry.

7th Pa. V. R. C.
Residence.

Hyde Park, $\mathrm{Pa}$.

Morgantown, W. Va.

Olney, Ill.

New York City.

Unionville, Conn.

Woodstock, Vt.

Waterloo, N. Y.

Le Roy, N. Y.

Short Tract, N. Y.

Canton, N. Y.

Pittsfield, Mass.

Shickshinny, Pa.

Tamaroa, Ill.

Bridgeton, Mre.

Vermont, Ill.

Maple Rapids, Mich.

Maple Rapids, Mich.

Mount Clemmun, Mich

Huntington, Ind.

Muscatine, Iowa.

Alden, Iowa,

Duncannon, $\mathrm{Pa}$.

Elba, N. Y.

Phœnixville, $\mathrm{Pa}$.

Ontario, N. Y.

Freehold, N. J.,

Ypsilanti, Mich.

Rollersville, $\mathrm{O}$.

Milford, Mass.

West Concord, Vt.

Wheeling, W. Va. 
same.

riley, W. L.,

Ring, A.,

Rice, J. S.,

Rose, W. B.,

Rose, J. C.,

Rowley, G. A.,

Robinson, B. E.,

Robeson, J. S.,

Roberts, E. R.,

Roach, W. E.,

Rothe, H.,

Ross, C. H.,

Ruger, J. M.,

Rugg, C. L.,

Sargeant, M. G.,

Sandon, W.,

Sailor, J.,

Sanders, C. B.,

Scarr, C.,

Scott, Geo.,

Schwartz, C. S.,

Scripture, F. E.,

Schulter, II.,

Schofield, T. D.,

Seely, L. D.,

Shofer, W. H.,

Shanan, Mr.,

Shannon, A. L.,

Shepstrong, M. N.,

Shechan, J. P.,

Shull, J. F.,

Shacfer, N. W.,

Sitler, J. R.,

Simmons, A. B.,

Simmondson, P. A.,

Skinner, J. I.,

Slout, J. O.,

Smith, E. B.,

Smith, MI. S.,
Regiment or Command.

21st N. Y. Caralry,

12th O. Infantry.

13th Ind. Infantry,

73d Ill. Infantry.

120th Ill. Infantry,

$2 \mathrm{~d}$ U. S. Infantry.

95th O. Infantry,

7th Tenn. Cavalry,

7th IIl. Infantry.

49th N. Y. Infantry,

15th N. Y. Artillery,

13th Ind. Infantry,

57th $\mathrm{Pa}$. Infantry.

6th Ind. Cavalry,

1st Vt. Artillery,

1st Wis. Cavalry,

13th $\mathrm{Pa}$. Cavalry,

25th U. S. C. T.

7th N. Y. Artillery.

10th Ind. Infantry,

2d N. J. Cavalry,

A. Q. M. U. S. Vols.

43d N. Y. Infantry,

27th Mich. Infantry.

45th Pa. Infantry,

5th Pa. Cavalry.

14th N. Y. Infantry.

3d Ind. Cavalry,

60th O. Infantry.

31st Mre. Infantry,

28th U. S. C. T.,

24th Ind. Cavalry.

2d Pa. Cavalry,

5th Ind. Cavalry,

23d U. S. C. T.

27th Mass. Infantry,

- O. Cavalry,

1st Vt. Artillery,

16th Me. Infantry,
Besidence.

Brighton, N. Y.

Washington, Iown

Vienna, Ill.

Reynoldsburg, $\mathrm{ra}$.

Huntington, Tenn.

Rochester, N. Y.

Alexandria, $\mathrm{Va}$.

Janesville, $\mathrm{Pa}$.

Newport, Ky.

Newport, Vt.

Ontario, Wis.

Newport, $\mathrm{Pa}$.

Lebanon, MId.

Philadelphia, $\mathrm{Pa}$.

Albany, N. Y.

Knoxville, $\mathrm{Pa}$.

Hanover, Ind.

Dennysville, Me.

Bloomington, Ind.

Harmonsbarg, $\mathrm{Pa}$

Union City, Indians.

Amherst, Mass.

Wooster, $\mathrm{O}$.

Newport, Vt.

East Livermore, Me. 
same.

Smith, A. MI.,

Smith, J. C.,

Smith, J. B.,

Smith, J. P.,

Smith, P.,

Smith, J.

Smith, S. B.,

Smythe, S. S.,

Smyser, H. C.,

Snowwhite, E.,

Spring, B.,

Sturgeon, W. B.,

Stover, M. H.,

Stover, A. C.,

Stallman, C. H.,

Sterens, F.,

Stevens, J. G.,

Sterens, Frank,

Stewart, A. S.,

Stewart, R. R.,

Stuart, C.,

Strickland, E. P.,

Stebbens, J.,

Stanton, J. W.,

St. John, W. H.,

Starr, H. P.,

Stone, C. P.,

Stauber, B. F.,

Striblings, MI. W.,

Swift, E.,

Sweet, W. ㅍ. S. S.,

Sweetland, A. A.,

Swope, C. T.,

Tainter, H. S.,

Tanner, D.,

Taylor, J.,

Taw, E. C.,

Tiffany, A. W.,

Timm $\Lambda$.,
Regiment or Command.

1st Tenn. Cavalry.

24th Ind. Battery.

5th W. Va. Cavalry.

49th Pa. Infantry,

4th Tenn Cavalry,

5th Pa. Cavalry.

30th U. S. C. T.,

1st IIl. Arttllery,

2d IId. Infantry,

7th Pa. V. R. C.,

75th O. Infantry.

107th $\mathrm{Pa}$. Infantry,

181th Pa. Infantry.

95th O. Infantry,

8ith $\mathrm{Pa}$. Infantry,

190th $\mathrm{Pa}$. Infantry.

52d Pa. Infantry.

15th Pa. V. P. C.

4th Ky. Infantry,

2d - Cavalry.

24th N. Y. Infantry,

114th Ill. Infantry.

7ith N. Y. Infantry.

5th Ind. Cavalry,

5th Ind. Caralry,

$22 d$ N. Y. Caralry,

1st Vt. Cavalry,

20th Pa. Caralry,

61st O. Infantry,

74th Ill. Infantry,

146 th N. Y. Infantry,

2d Pa. Cavalry.

4th Ky. Infantry.

s2d N. Y. Infantry.

118th $\mathrm{Tl}$. Infantry.

2d Pa. V. R. C.

67th N. Y. Infantry.

9th Minn. Infantry,

16th Ia. Infantry,
Resilence.

Spring Mills, $\mathrm{Pa}$.

Morristown, $\mathrm{Pa}$.

Woodbury, N. Y.

Elkhorn, Ill.

Ashland Furnace, Fa.

Palmyra, Pa.

Shippensburg, $\mathrm{Pa}$

Urbania, 0 .

York, $\mathrm{Pa}$.

Meadow Gap, Pa.

New York City.

Carmel, Ind.

Greensburg, Ind.

Rochester, N. Y.

Brattleboro, Vt.

Lewistown, $\mathrm{Pa}$.

Circleville, $\mathrm{O}$.

Pecatomica, Ill.

Utica, N. Y.
Carver, Minn.

Davenport, Md. 
Name.

Tinker, S. H., Tipton, A. F., Tompkins, H. V., Tompson, J. S., Todd, O., Tower, D. W., Tomeon, $\mathrm{F}$. Topel, C., Toby, J. P. F., Trout, B. W., Turner, David, Tyler, L. E., Van Alin, W. C., Van Doren, D., Van Rensalaer, C., Von Bulow, A., Von Valack, D.D., Warren, J. W., Warren, D. H., Ward, T. H., Warner, J. B., Warner, J., Walker, J., Waterman, F., Watson, J. C., West, O. W., West, D. J., Wentworth, H. A., Weddle, Geo.,

Weisner, T. A., Whittemore, B. W., Wheaton, J., Whitten, B. F., Wheeler, J. F., Winters, J., Wilcox, C. W., Wing, G. H., Wilson, E. S., Wilson, R. P.,
Regiment or Command. 93d Ind. Infantry, 8th Ia. Cavalry, 59th N. Y. Infantry. 10th Vt. Infantry. 18th Wis. Infantry, 17th Ia. Infantry, 17th Ia. Infantry. 15th N. Y. Artillery, 31st Me. Infantry, 106th Pa. Infantry, 118th Ill. Infantry, 1st Conn. Cavalry, 45th $\mathrm{Pa}$. Cavalry, 72d O. Infantry, 148th N. Y. Infantry, 3d N. J. Cavalry, 12th U. S. Infantry. 1st Wis. Cavalry, sth Ia. Cavalry, 59th U. S. C. T. 8th Mich. Cavalry, 33d N. J. Infantry, 8th Tenn. Infantry, 16th Ia. Infantry, 126th O. Infantry, 1st U. S. Dragoons, 6th Conn. Infantry, 14th N. Y. Artillery, 145th O. Infantry, 14th III. Infantry, 5th N. Y. Cavalry. 59th U. S. C. T. 9th Me. Infantry. 149th N. Y. Infantry, 72d O. Infantry, 9th N. H. Infantry. 14th N. Y. Artillery, 1st Mass. Cavalry, 5th U. S. Cavalry,
Residence.

Allensville, Ind.

Elkader, Iowa

Adrian, Mich.

Farmington, Iowa.

New York City.

Machias Post, MIc.

Canton, $\mathrm{Pa}$.

Warsaw, Ill.

Preston, City, Conn.

Fleming, $\mathrm{Pa}$.

Fremont, 0 .

Seneca Falls, N. Y.

New York City.

Beaver Dam, Wis.

Glencoe, $\mathbf{O}$.

Marshall, Mich.

Newark, N. J.

Ball's Gap, Tenn.

Davenport, Ia.

New Salem, 0.

Dansville, N. Y.

Bridgeport, Conn.

Randolph, N. Y.

Perrysbarg, 0.

Greenfleld, Ill.

Salina, N. Y.

Townsend, $\mathbf{O}$.

Glenn's Falls, N. Y.

Havana, Cuba.

Philadelphia, $\mathrm{Pa}$. 
Name.

Wilson, R.,

Willis, H. H.,

Winship, J.,

Williams, W.,

Wilker, W. H.,

Woodruff, F. M.,

Woodrow, C. W.,

Young, W. J.,

Young, T. P.,

Young, A,

York, J. H.,

Zeigler, Aaron,

Zimini, A,

Zobel, C.,
Regiment or Command. 113th Ill. Infantry,

40 th N. Y. Infantry, ssth III. Infantry,

8th Mich. Cavalry.

4th O. Infantry,

76th N. Y. Infantry,

19th Ia. Infantry,

111th Ill. Infantry,

sth Ky. Infantry.

4th $\mathrm{Pa}$. Cavalry,

63d Ind. Infantry.

7th Pa. V. R. C.,

15th Ia. Infantry.

15th N. Y. Artillery.
Residence.

Chicago, Ill.

Aurora, IIl.

Chicago, 11 .

Arcadia, 0.

Oswego, N. Y.

Mount Pleasant, Iow

Xenia, Il.

Nicwark, N.J.

Myerstown, $\mathbf{P a}$ 


\section{TESTIMONIALS.}

EXTRACTS FROM NOTICES OF THE PRESS.

\section{Missouri Republican.}

' "'The Capture, the Prison-Pen, and the Escape,' by Captain Willard Worcester Glazier, is the most comprehensive as well as the most intercsting work on Prison Life jet published."

\section{Forney's War Press.}

"It is an accurate narrative of exciting and marvellous erents. The book is destined to have a very large sale, devoted as it is to scenes in which so many thousands have a melancholy interest."

\section{Northern Recorder.}

"'The Capture, the Prison-Pen, and the Escape.' The work above titled gives a complete history of prison life in the South. Willard Worcester Glazier, the author of this work, is a native of St. Lawrence County, and was for some time a student of "Gouverneur Wesleyan Seminary," where we formed his acquaintance. From his standard integrity and firm alliance with principle and truth, none need look for anything in this work except that which will bear the strictest test. This book is full of thrilling interest, and as the works of the Great Rebellion are ever to be fresh in the minds of the American people, it will be read with increasing interest."

\section{St. Lavorence Plaindealer.}

"The branch of servioe to which Captain Glazier belonged, and the scenes upon which fortune threw him, have given him the material for a highly interesting book, and he has ased it well. His statements are endorsed by those who were associated with him, and are full of interest. During one of the cavalry fights between Stuart and Kilpatrick, Captain Glazier was captured, and remained a prisoner for fourteen months. A complete picture of prisonlife is given. An ordinary history of the war, in which proclamations, politics, grand tactics, and like weighty matters are dealt with, may give a wonderful amount of useful information ; bat a well-written and trutbful work like that above alluded to, is essentlal to one who would nuderstand the details of the late war." 


\section{Oswego Union.}

"We hope this work will meet with a ready sale, because it makes our people better acquainted with what our brave soldiers endured, in their patriotic and self-sacrificing efforts to save the nation."

\section{New York Reformer.}

"From the title-page to its close the volume is full of fresh incidents, at tracting the reader on, from page to page, with unbroken, thongh at times with melancholy, at others indignant, and at others wrathful interest"

\section{Canandaigua Times.}

"The Great Rebellion has afforded material for but few, if any, more interesting narratives than that embraced within the pages of a new book entitled, 'The Capture, the Prison-Pen, and the Escape,' by Captain Willard Worcester Glazier, late of the Second New York (Harris Light) Cavalry. The work gives an interesting and graphic account of Prison Life as it was endured by the 'boys in blue,' at Richmond, Danville, Macon, Savannah, Charleston, Columbia, Millin, Salisbury, and Andersonville."

\section{Schenectady Union.}

" ' The Capture, the Prison-Pen, and the Escape,' is the most accurate and in. teresting work on Prison Life yet offered to the public. As we were with Captain Glazier in prison, we can testify to the authenticity of his statements."

\section{Chicago Tribune.}

"It abounds in thrilling incidents of the Field, Prison, and Escape, and is a highly interesting and instructive work. We have given it a careful examination, and most cheerfully commend it to all who desire accurate and reliable information upon the matter of which it treats."

\section{Utica Morning Herald.}

"The book is handsomely printed, illustrated, and bound, and will be a very acceptable addition to the literatore of the Rebellion."

\section{Detroil Advertiser and Tribune.}

"The greater portion of this interesting work consists of the pages of a journal kept while the author was a prisoner of war, and preserved only by dint of considerable strategy. It shows us the cheerful as well as the dark side of captivity - the cheerfulness that a buoyant and brave spirit maintains through suffering and peril, and reawakens our pride in the enduring conrage and loyalty and manliness that our soldiers displayed through every ordeal."

\section{Detroit Daily Union.}

"It is a volume that abounds in thrilling incidents of fact, not needing the romance of the novelist to enchain the reader. The work is a finely bound rolume of over 400 pages, profusely illustrated with engravings, representing many of the scenes of which the author was a witness. As a history of war- 
events and scenes, and showing the character of Southern Prison Life, it is a work valuable alike for present use and preservation."

$$
\text { Alvany Evening Post. }
$$

"' 'The Capture, the Prison-Pen, and the Escape.' This is the title of an intensely interesting work, giving a complete history of Prison Life in the South. The book is at once accurate, graphic, and admirably written. It is full of adventure, and quite as readable as a romance. A person who reads this volume will have a better idea of what it cost in the way of blood, suffering, and courage to prescrve the Republic, than he can now possibly entertain."

\section{Cleveland Daily Leader.}

" 'The Captnre, the Prison-Pen, and the Escape.' We have had the pleasure of reading this book. It describes in the most graphic and interesting style the Prison Life of Union soldiers in the South, their plans of cscape, and their various trials and hardships there. The history contained in the book itself is very valuable, to say nothing of an appendix which contains the names and post-oflice address of many of the officers imprisoned in Libby during the war. The press all over the land speaks very highly of it, and we can do naught but add our commendations to the rest."

\section{Albany Evening Times.}

"Among the many valuable and interesting volumes that have been written since the close of the Great Rebellion, none, perhaps, are more worthy than the one entitled 'The Capture, the Prison-Pen, and the Escape.' The anthor, Willard Worcester Glazier, is very well and favorably known in these parts. The work is a history of facts and incidents of army and prison life, as they occurred under his own observation, during an imprisonment of fourteen months in several of the Southern prisons. In a statistical point of view it is very valuable, as it gives reliable data of the deaths of Union soldiers at Andersonville and Florence. Its descriptions of places and events that happened during the war are admirably penned, and read more like romance than the stern reality so faithfully portrayed. It is as fascinating as a novel, and yet an 'o'er-trne tale.' As its title indicates, it is filled with daring adventures and hair-breadth escapes, interspersed with thrilling accounts of the suffering of our brave boys in those dreadful Southern prisone." 



\section{AGENTS WANTED !}

Cor This Book is sold principally by Subscription:

And we want an Agent in erery town and county in the United States Our terms are liberal, and the profit of the business sure.

Teachers, ladies, energetic joung men, and especially returned and disabled officers and soldiers, in want of profitable employment, wil. find this work particularly adapted to their condition.

For full particulars, terms, etc., address

\section{B. I. FERGUSON \& CO., Publishers,}

138 Bleecker St., New York. 
N 





